Prepared for the U.S. Department of Energy

By AmerenUE and MEC Water Resources, Inc.

Performance Period: September 2002 - December 2005

Submitted: August 2006

\title{
Final Report: \\ Retrofit Aeration System (RAS) \\ for Francis Turbine
}

\author{
Contact person at AmerenUE: \\ Allan Sullivan \\ Project Principal Investigator \\ Manager Osage Dam and Plant \\ 617 River Road, Eldon, MO 65047 \\ Phone: (573) 365-9329 \\ Email: asullivan@ameren.com
}

\author{
Project Contact at U.S. Dept of Energy, \\ Golden Field Office: \\ DOE Project Officer - Keith Bennett \\ 1617 Cole Blvd., Golden, CO 80401 \\ Phone: 303-275-4700 \\ Email: Keith.Bennett@go.doe.gov
}

Acknowledgment: "This material is based upon work supported by the Department of Energy under Award Number DE-FC36-02ID14408."

Disclaimer: "This report was prepared as an account of work sponsored by an agency of the United States Government. Neither the United States Government nor any agency thereof, nor any of their employees, makes any warranty, express or implied, or assumes any legal liability or responsibility for the accuracy, completeness, or usefulness of any information, apparatus, product, or process disclosed, or represents that its use would not infringe privately owned rights. Reference herein to any specific commercial product, process, or service by trade name, trademark, manufacturer, or otherwise does not necessarily constitute or imply its endorsement, recommendation, or favoring by the United States Government or any agency thereof. The views and opinions of authors expressed herein do not necessarily state or reflect those of the United States Government or any agency thereof." 


\section{TABLE OF CONTENTS}

\section{INTRODUCTION}

\section{TURBINE EVALUATION STUDY DESIGN AND METHODOLOGY}

II.A. 2005 Turbine Evaluation 4

II.A.1. Plant Operations $\quad 5$

II.A.2. Turbine Barrel and Draft Tube Vent Airflow Sampling 5

II.A.3. Discrete Sampling $\quad 5$

II.A.4. Continuous Monitoring $\quad 7$

$\begin{array}{ll}\text { II.B. Quality Assurance } & 7\end{array}$

$\begin{array}{ll}\text { III. RESULTS AND DISCUSSION } & 8\end{array}$

III.A. Water Temperature 8

III.A.1. Water Temperature - $2005 \quad 8$

III.A.2. Water Temperature Comparison of Study Years $\quad 8$

$\begin{array}{lr}\text { III.B. Airflow } & 9\end{array}$

III.B.1. Main Generator 6 Airflow - 2005

III.B.2. Main Generator 6 Airflow - Comparison of Study Years 10

III.B.3. Main Generator 3 Airflow - $2005 \quad 11$

III.B.4. Main Generator 3 Airflow - Comparison of Study Years $\quad 11$

III.B.5. Main Generators 3 and 6 Airflow Comparison - 2005

III.C. Dissolved Oxygen 12

III.C.1. Main Generator 6 Dissolved Oxygen - 2005

III.C.2. Main Generator 6 Dissolved Oxygen - Comparison of Study Years 15

III.C.3. Main Generator 3 Dissolved Oxygen - $2005 \quad 16$

III.C.4. Main Generator 3 Dissolved Oxygen - Comparison of Study Years 16

III.C.5. Main Generator 3 and 6 Dissolved Oxygen Comparison - 2005

$\begin{array}{lr}\text { III.D. Aeration Performance } & 18\end{array}$

$\begin{array}{lr}\text { III.D.1. Aeration Performance - } 2005 & 18\end{array}$

III.D.2. Aeration Performance - Comparison of Study Years 19

$\begin{array}{lr}\text { III.E. Total Dissolved Gas } & 20\end{array}$

III.E.1. Total Dissolved Gas - $2005 \quad 20$

III.E.2. Total Dissolved Gas - Comparison to Study Years 22

$\begin{array}{ll}\text { IV. CONCLUSIONS } & \mathbf{2 3}\end{array}$

$\begin{array}{ll}\text { IV.A. General Findings } & 23\end{array}$

$\begin{array}{lr}\text { IV.B. Main Generator } 6 & 23\end{array}$

$\begin{array}{lr}\text { IV.C. Main Generator } 3 & 25\end{array}$

IV.D. Comparison of Main Generators 3 and $6 \quad 26$ 
MEC Water Resources, Inc.

Osage Project Supplemental Turbine Testing Report

\section{LIST OF APPENDICES}

Appendix 1 - Report Figures and Table

Appendix 2 - Field and Calculated Data Tables 


\section{APPENDIX 1}

\section{LIST OF FIGURES}

Figure 1: Modifications made to Main Generator 6 - 2003 and 2005

Figure 2: Diagram of Discrete Sampling Device

Figure 3: Photograph of Discrete Sampling Device

Figure 4: Photograph of Discrete Sampling Device - Deployed

Figure 5: Relationship between Standard Air Flow and Discharge - Main Generator 6 Four New Main Vents Only - 7/26/05 \& 7/27/05

Figure 6: Relationship between Air Flow and Discharge - Main Generator 6 - Draft Tube Vent Only - 7/26/05 \& 7/27/05

Figure 7: Relationship between Air Flow and Discharge - Main Generator 6 - Draft Tube and Four New Main Vents - 7/26/05 \& 7/27/05

Figure 8: Relationship between Standard Air Flow and Discharge - Tailrace Elevations 553- 2005 Main Generator 6

Figure 9: Relationship between Standard Air Flow and Discharge - Tailrace Elevation 556 - 2005 Main Generator 6

Figure 10: Relationship between Standard Air Flow and Discharge - Tailrace Elevation 560 - 2005 Main Generator 6

Figure 11: Relationship between Standard Air Flow and Discharge - Tailrace Elevation 563 - 2005 Main Generator 6

Figure 12: Relationship between Standard Air Flow and Discharge - Main Generator 6 2002 \& 2003 - Two Original Main Vents \& 2005 - Four New Main Vents Tailrace Elevation 554

Figure 13: Relationship between Standard Air Flow and Discharge - Main Generator 6 2002 \& 2003 - Two Original Min Vents \& 2005 - Four New Main Vents Tailrace Elevation 557 and 556

Figure 14: Relationship between Standard Air Flow and Discharge - Main Generator 6 2002 \& 2003 - Two Original Main Vents \& 2005 - Four New Main Vents Tailrace Elevation 560

Figure 15: Relationship between Standard Air Flow and Discharge - Main Generator 6 2002 \& 2003 - Two Original Main Vents \& 2005 - Four New Main Vents Tailrace Elevation 563

Figure 16: Relationship between Standard Airflow and Discharge - Main Generator 6 2002 \& 2003 - Auxiliary Vents and Two Original Main Vents \& 2005 - Draft Tube and Four New Main Vents - Tailrace Elevation 557 and 556

Figure 17: Relationship between Standard Airflow and Discharge - Main Generator 6 2002 \& 2003 - Auxiliary Vents and Two Original Main Vents \& 2005 - Draft Tube and Four New Main Vents - Tailrace Elevation 560

Figure 18: Relationship between Standard Airflow and Discharge - Main Generator 6 2002 \& 2003 - Auxiliary Vents and Two Original Main Vents \& 2005 - Draft Tube and Four New Main Vents - Tailrace Elevation 563

Figure 19: Relationship between Standard Air Flow and Discharge - Main Generator 3 Four Main Vents - 7/26/05 
Figure 20: Relationship between Standard Air Flow and Discharge - Main Generator 3 Two Main Vents - 7/26/05

Figure 21: Relationship between Standard Air Flow and Discharge - Main Generator 3 One Main Vents - 7/26/05

Figure 22: Relationship between Standard Air Flow and Discharge - Tailrace Elevation 556 - 2005 Main Generator 3

Figure 23: Relationship between Standard Air Flow and Discharge - Tailrace Elevation 560 - 2005 Main Generator 3

Figure 24: Relationship between Standard Air Flow and Discharge - Tailrace Elevation 563 - 2005 Main Generator 3

Figure 25: Relationship between Standard Air Flow and Discharge - 2002, 2003, \& 2005 Main Generator 3 - Four Main Vents - Tailrace Elevation 557 and 556

Figure 26: Relationship between Standard Air Flow and Discharge - 2002, 2003 \& 2005 Main Generator 3 - Four Main Vents - Tailrace Elevation 560

Figure 27: Relationship between Standard Air Flow and Discharge - 2002, 2003 \& 2005 Main generator 3 - Four Main Vents - Tailrace Elevation 563

Figure 28: Relationship between Standard Air Flow and Discharge - Tailrace Elevation 556 - 2005 Main Generator 3 and 6

Figure 29: Relationship between Standard Air Flow and Discharge - Tailrace Elevation 560 - 2005 Main Generator 3 and 6

Figure 30: Relationship between Standard Air Flow and Discharge - Tailrace Elevation 563 - 2005 Main Generator 3 and 6

Figure 31: Relationship between Discharge DO and Discharge - Tailrace Elevation 553 2005 Main Generator 6

Figure 32: Relationship between Discharge DO and Discharge - Tailrace Elevation 556 2005 Main Generator 6

Figure 33: Relationship between Discharge DO and Discharge - Tailrace Elevation 560 2005 Main Generator 6

Figure 34: Relationship between Discharge DO and Discharge - Tailrace Elevation 563 2005 Main Generator 6

Figure 35: Relationship between Discharge DO and Discharge - Main Generator 6- 2002 \& 2003 - Two Original Main Vents \& 2005 - Four New Main Vents - Tailrace Elevation 554

Figure 36: Relationship between Discharge DO and Discharge - Main Generator 6 - 2002 \& 2003 - Two Original Main Vents \& 2005 - Four New Main Vents - Tailrace Elevation 557

Figure 37: Relationship between Discharge DO and Discharge - Main Generator 6- 2002 \& 2003 - Two Original Main Vents \& 2005 - Four New Main Vents - Tailrace Elevation 560

Figure 38: Relationship between Discharge DO and Discharge - Main Generator 6 - 2002 \& 2003 - Two Original Main Vents \& 2005 - Four New main Vents - Tailrace Elevation 563

Figure 39: Relationship between Discharge DO and Discharge - Main Generator 6-2002 \& 2003 - Auxiliary Vents and Two Original Main Vents \& 2005 - Draft Tube and Four New Main Vents - Tailrace Elevation 557

Figure 40: Relationship between Discharge DO and Discharge - Main Generator 6 - 2002 \& 2003 - Auxiliary Vents and Two Original Main Vents \& 2005 - Draft Tube and Four New Main Vents - Tailrace Elevation 560

2005 Supplemental Turbine Testing/7/6/2006 
Figure 41: Relationship between Discharge DO and Discharge - Main Generator 6-2002 \& 2003 - Auxiliary Vents and Two Original Main Vents \& 2005 - Draft Tube and Four New Main Vents - Tailrace Elevation 563

Figure 42: Relationship between Discharge DO and Discharge - Tailrace Elevation 556 2005 Main Generator 3

Figure 43: Relationship between Discharge DO and Discharge - Tailrace Elevation 5602005 Main Generator 3

Figure 44: Relationship between Discharge DO and Discharge - Tailrace Elevation 563 2005 Main Generator 3

Figure 45: Relationship between Discharge DO and Discharge - 2002, 2003 \& 2005 Main Generator 3 - Four Main Vents - Tailrace Elevation 557

Figure 46: Relationship between Discharge DO and Discharge - 2002, 2003 \& 2005 Main Generator 3 - Four Main Vents - Tailrace Elevation 560

Figure 47: Relationship between Discharge DO and Discharge - 2002, 2003 \& 2005 Main Generator 3 - Four Main Vents - Tailrace Elevation 563

Figure 48: Relationship between Discharge DO and Discharge Tailrace Elevation 556 2005 Main Generator 3 and 6

Figure 49: Relationship between Discharge DO and Discharge - Tailrace Elevation $560-$ 2005 Main Generator 3 and 6

Figure 50: Relationship between Discharge DO and Discharge - Tailrace Elevation 563 2005 Main Generators 3 and 6

Figure 51: Relationship between Dissolved Oxygen Increase and Air: Discharge Ratio Main Generator $3 \& 6-7 / 26 / 05$ \& 7/27/05

Figure 52: Relationship between Aeration Efficiency and Air: Discharge Ration - Main Generator $3 \& 6-7 / 26 / 05 \& 7 / 27 / 05$

Figure 53: Relationship between Oxygen Transfer Efficiency and Air: Discharge Ratio Main Generator $3 \& 6-7 / 26 / 05 \&$ 7/27/05

Figure 54: Relationship between Dissolved Oxygen Increase and Air: Discharge Ratio MG 3 \& $6-2002,2003 \& 2005$

Figure 55: Relationship between Aeration Efficiency and Air: Discharge Ratio - Main Generator 3, 4, \& $6-2002,2003$ \& 2005

Figure 56: Relationship between Oxygen Transfer Efficiency and Air: Discharge Ratio Main Generator 3, 4, \& 6- 2002, 2003 \& 2005

Figure 57: Relationship between Total Dissolved Gas and Air: Discharge Ratio - Main Generator $3 \& 6-7 / 26 / 05 \&$ 7/27/05

Figure 58: Relationship between Total Dissolved Gas and Discharge Dissolved Oxygen Main Generator $3 \& 6-7 / 26 / 05 \&$ 7/27/05

Figure 59: Relationship between Total Dissolved Gas and Dissolved Oxygen Increase Main Generator $3 \& 6-7 / 26 / 05$ \& 7/27/05

Figure 6o: Relationship between Total Dissolved Gas and Air: Discharge Ratio - Main Generator 3, 4, \& $6-2002,2003$ and 2005

Figure 61: Relationship between Total Dissolved Gas and Discharge Dissolved Oxygen Main Generator 3 \& $6-2002,2003$ and 2005

Figure 62: Relationship between Total Dissolved Gas and Dissolved Oxygen Increase Main Generator $3 \& 6-2002,2003$ and 2005 


\section{APPENDIX 2}

\section{LIST OF TABLES}

Table 1: 2002 Main Generator 3 Data

Table 2: 2002 Main Generator 6 Data - Auxiliary Vents Open

Table 3: 2002 Main Generator 6 Data - Auxiliary Vents Closed

Table 4: 2003 Main Generator 3 Data

Table 5: 2003 Main Generator 6 Data

Table 6: 2005 Main Generator 6 Data

Table 7: 2005 Main Generator 3 Data 


\section{INTRODUCTION}

AmerenUE has and continues to actively pursue technological advances to increase dissolved oxygen (DO) levels in the Bagnell Dam discharge. AmerenUE received a United States Department of Energy grant to evaluate the influences of these upgrades on aeration performance and resulting discharge DO. From 2002 through 2005 Ameren UE implemented various modifications to turbine design and operation while studying the effectiveness of these changes on discharge DO concentrations and other parameters of interest.

The hydroelectric power generation system at Bagnell Dam utilizes eight main turbines and two house turbines. In March 2002, AmerenUE replaced two turbines with new turbines designed to increase airflow, therefore enhancing aeration performance. The new turbines were installed at Main Generator $3\left(\mathrm{MG}_{3}\right)$ and Main Generator 5 (MG5). An original turbine (Main Generator 6 ) was also modified at this time by installing an auxiliary venting system (ten additional vents) to enhance aeration performance. This report presents the results of these evaluations.

The following is a list of the advanced upgrades made to units 3 and 6 from 2002 to 2005 to increase DO levels. Detailed discussions of these upgrades are presented in the following paragraphs:

\section{Main Unit 3}

2002

New turbine manufactured by American Hydro installed and in service by April 2002. The upgraded unit included four new 8 -inch vent pipes and increased air passage openings through the turbine head and runner crown. A newly designed perforated nosecone with bottom plate was also installed. 2003

The bottom plate of the nose cone was removed based on results from CFD airflow modeling.

2004

No physical changes made.

2005

Check valves were removed from the four vent pipes to minimize airflow restriction.

\section{Main Unit 6}

2002

Ten temporary auxiliary vents were installed and included in the testing. 2003

The opportunities for airflow were increased by:

- Drilling 16, 2-1/2" holes in the runner crown,

Installing a baffle ring around the nose cone,

Enlarging the holes in the nose cone sides,

- Re-Installing the auxiliary vents through turbine head cover.

2004

A draft tube door baffle with two 8" vent pipes was installed. 
2005

The draft tube door baffle was redesigned by replacing the two 8-inch vents with single 16-inch vent.

The unit was retrofitted with four 8 -inch vents and additional vent openings were drilled through the turbine head cover.

A 12-inch extension was installed on the bottom of the nose cone.

A study was conducted in August 2002 to compare the performance of a newly designed Francis turbine (MG3) to an original 1931 Francis turbine (MG6). The nosecone of MG3 was designed with numerous holes, approximately 2 " in diameter, around its periphery. The intent of this nosecone design was to enhance oxygen transfer efficiency by distributing air into small bubbles. The study also included an evaluation of the auxiliary venting system at MG6. AmerenUE retained MEC Water Resources, Inc. to develop and execute a method to measure discharge aeration during a series of operating scenarios selected by AmerenUE. The study was conducted on August 13, 2002. Duplicate data at low gate settings were collected on August 15, 2002. The draft report of this study titled "Osage Project Supplemental Turbine Testing Interim Report" was issued in May 2003. The final report was submitted in December 2003.

In March 2003, Ameren modified MG3 by removing a bottom plate from the turbine's nosecone. The removal of this plate was expected to allow greater airflow into the turbine, based upon computational fluid dynamics (CFD) analysis performed by American Hydro Corporation, the manufacturer of the upgraded turbine. MG6 was also modified to increase airflow during this outage. The MG6 modification consisted of drilling holes in the runner crown, enlarging the existing holes in the nosecone sides and installing a baffle ring around the nose cone, again based upon American Hydro modeling efforts. To measure changes in turbine performance following the March 2003 modifications, the turbine evaluation procedure conducted in August 2002 was repeated on August 13, 2003 .

In September 2004, AmerenUE installed vents in the draft tube of MG6 to increase venting airflow. A baffle with two eight inch vents was installed the draft tube door. CFD analysis suggested that these relatively simple vents may significantly increase vent airflow. The MG6 auxiliary vents were also reinstalled for comparison to the draft tube vents. A study was conducted on September 7, 2004 to determine the effect of these modifications on MG6 discharge water. Results were not reported because the draft tube vent was modified shortly after the 2004 study.

During April 2005 MG6 was modified again with the retrofit of four new main vents, a redesigned draft tube vent and a nosecone extension (Figure 1). The new eight-inch main vents replaced the auxiliary vents that were used in previous studies. The new main vents are similar to the $M_{3}$ and $M_{5}$ vents and can be remotely operated, whereas the auxiliary vents were operated manually. The two draft tube vents were replaced with a single sixteen-inch vent pipe and the baffle was extended further into the draft tube. The nosecone modification was based on CFD modeling that indicated a low pressure area below the nosecone and a 12 -inch nosecone extension would maximize airflow. The draft tube vent was equipped with a pneumatic butterfly valve providing remote operation capabilities. Minor modifications were also made in July 2005 to MG3, including removal of main vent check valves to reduce airflow restrictions. 
MEC Water Resources, Inc.

Osage Project Supplemental Turbine Testing Report

This report presents the methodology, results and conclusions of the 2005 evaluation and provides a comparison to 2002 and 2003 evaluations. All of the study figures and several of the study tables are provided in separate appendices (Appendices 1 and 2, respectively) to aid report readability. 
MEC Water Resources, Inc.

Osage Project Supplemental Turbine Testing Report

\section{TURBINE EVALUATION STUDY DESIGN AND METHODOLOGY}

II.A. 2005 Turbine Evaluation

The 2005 study employed a matrix (Table 1) of fifty-one operational scenarios that were comparable to previous studies measured over a two day period (July 26 and 27). The 2005 data were collected to assess turbine aeration modifications incorporated since the 2003 and 2004 evaluations. Discrete and continuous monitoring was conducted for each operational scenario. Discrete monitoring consisted of measuring:

- turbine intake vent airflow at the turbine barrels of the study units,

- DO, total dissolved gas (TDG) and temperature of discharge from study units, and

- barometric pressure at the tailrace.

Continuous monitoring consisted of measuring $\mathrm{DO}$ and temperature in the $\mathrm{MG}_{3}$ and MG6 intake water, as well as, air temperature and barometric pressure at the turbine barrels and draft tube of MG6.

Table 1

2005 Turbine Evaluation Study Matrix

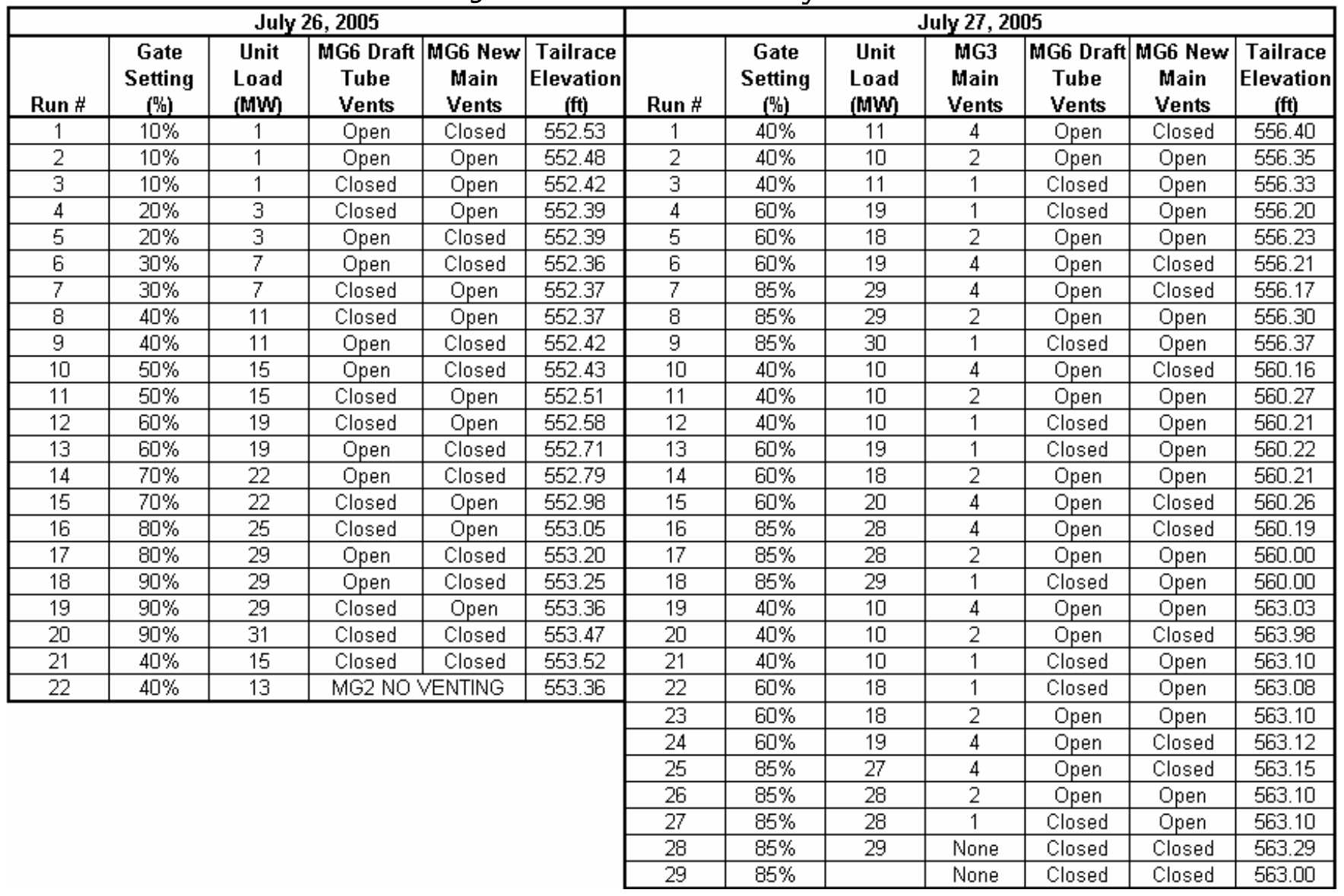


II.A.1. Plant Operations

Control room staff made necessary adjustments to achieve the desired tailrace elevations and flow rates targeted in the study matrix. Tailrace elevations were controlled by operation of the other turbines.

Four tailrace elevations were studied as shown in Table 1. Upon reaching each of the target tailrace elevations, gates and vents for $\mathrm{MG}_{3}$ and MG6 were adjusted to the desired configuration. A low gate setting (10\% providing $1 \mathrm{MW}$ ) was only studied at the lowest tailrace elevation ( $552 \mathrm{ft} \mathrm{MSL}$ ). The remaining gate settings were evaluated throughout the range of tailraces, including 40\%,60\%, 80\%, 90\% and $85 \%$ gate settings (replaced $80 \%$ and $90 \%$ on Day 2). However, the higher gate settings at the 552 feet tailrace elevation could not be achieved without surpassing the target tailrace elevation. $\mathrm{MG}_{3}$ was operated with 1, 2 or 4 vents open. MG6 was operated with two original vents open continuously in conjunction with one of the following configurations: four new main vents open/draft tube vent closed, the four new main vents closed/draft tube vent open or four new main vents open/draft tube vents open.

\section{II.A.2. Turbine Barrel and Draft Tube Vent Airflow Sampling}

Airflow monitoring of MG3 and MG6 vents was performed by AmerenUE personnel.

Dwyer model 640 and 641 Air Velocity Transmitters were used to measure airflow through all vents on $\mathrm{MG}_{3}$ and MG6 (including draft tube vent on MG6). Models 640 and 641 are identical in functionality, with the 640 being a slightly older model. These transmitters have an air velocity range up to $15,000 \mathrm{ft} / \mathrm{min}$, using a heated mass flow sensor inserted into the vent pipe and held in a fixed position. The transmitter output was connected to the plant SCADA system for data collection. Raw data values were converted into velocity by post measurement processing methods.

\section{II.A.3. Discrete Sampling}

MEC Water Resources crew(s) collected DO data in the tailwater immediately downstream of the $\mathrm{MG}_{3}$ and MG6 discharges during the two-day sampling event. Day one (July 26,2005 ) sampling was conducted by two crews consisting of two boats, each with three crew members. Crews measured DO, temperature and TDG at the $\mathrm{MG}_{3}$ and MG6 discharges. Tailrace elevations of 556,560 and 563 were targeted with gates settings of $40 \%, 60 \%$ and $85 \%$. MG 3 venting configurations consisted of 1,2 and 4 of the main vents open. MG6 venting configurations were: four new main vents open/draft tube vent closed, the four new main vents closed/draft tube vent open, and four new main vents open/draft tube vents open. The two original vents were open for all sampling scenarios. The day two (July 27, 2005) crew consisted of a boat with three crew members that measured DO, temperature and TDG at the MG6 discharge. Day two efforts focused on sampling MG6 discharge at tailrace elevation 553, gate settings of $10 \%$ to $90 \%$ (in increments of 10\%), and for all venting configurations.

The turbine discharge was very turbulent, raising concerns that the turbulence and the presence of numerous air bubbles would interfere with DO measurement stability. A relatively large amount of DO variability was observed within the turbine discharges during prior field studies. This variability was likely influenced by the entrained air bubbles. Therefore, a sampling device was designed and constructed from PVC pipe and fittings to capture discrete samples of the turbine discharge. A diagram of the sampling device and its use is presented in Figure 2. Photographs of the devices are provided in 
Figures 3 and 4 . The device was submerged to collect samples at a depth of approximately 1-meter below the water surface.

Crews were equipped with water quality sondes (YSI $600 \mathrm{XLM}$ sonde) and handheld data logger (YSI 650 Datalogger) to measure and store the DO measurements. TDG data were collected using Common Sensing, Inc. TBO-DL6-F TDG meter. Once it was confirmed that the target operational scenario was reached, the crews approached the outflow boil and maintained a steady position approximately 10 meters from the downstream face of the powerhouse.

TDG and DO concentrations were monitored within the sampling apparatus. Once DO readings were relatively stable, a sample was collected by lowering a sleeve over the monitors, which captured a water sample in the sampling chamber. The boat was then allowed to drift away from the dam. The water quality data sonde and TDG meter were slowly raised and lowered to prevent bubble formation on the TDG probe membrane. The DO measurements from the water in the chamber were then recorded manually every 10 seconds. Logging was stopped in three to five minutes after readings had stabilized. The crew then communicated by radio to the coordinator that the sampling run was completed.

The sampling crews were assigned to measure tailrace TDG, DO and temperature for each tailrace elevation and gate setting with the various venting configurations. Once the sampling crews confirmed collection of representative data from a sampling run, AmerenUE employees operating the turbine then altered the vent configurations. When confirmation was received that the vents were altered, the turbine discharge crews would again approach the boil, collect the discrete sample and record the corresponding measurements.

The control room raised the tailrace after crews sampled the targeted gate settings at each tailrace elevation. Tailrace elevations were modified by adjusting flow rates and number of discharging units. Tailrace elevation adjustments were completed within 5 to 30 minutes. During tailrace adjustments, the MEC Water Resources crews performed a quality control check of the monitoring equipment by comparing in-stream DO at the same location using both sondes.

Sampling resumed after confirming the next target operational scenario and completing quality control measurements. Sampling for the remaining operational scenarios followed the same procedural steps as previously described.

Index testing was performed to determine discharge rates from the units at the various tailrace elevations and gate settings. Tests were conducted by measuring the pressure across a number of taps on the discharge unit. These pressure data are collected by AmerenUE's SCADA system and later evaluated to determine discharge rates. 


\section{II.A.4. Continuous Monitoring}

MEC Water Resources deployed water quality monitoring sondes within intake water flow chambers at MG3 and MG6. Intake water was collected through four equally spaced taps on the intake tube of the unit. These taps were then connected to one another and run to the PVC flow chamber. Connecting the taps into a single line was done to try to create a representative sample of the intake water. The sondes at MG 3 and MG6 were programmed to log DO and water temperature at one minute intervals for the duration of the study. Van Hessen Barologgers were placed in the MG3, MG6 turbine barrels, as well as near the draft tube of MG6. The barologgers were programmed to collect changes in pressure at one minute intervals.

\section{II.B. Quality Assurance}

MEC Water Resources developed standard operating procedures to measure discrete tailrace DO and TDG concentrations. These procedures included quality control checks to confirm instrument calibration. DO concentrations were measured with the field instrument along with a replicate instrument to check instrument calibration and consistency between the DO readings. The TDG meter was calibrated according to the manufacturer's recommendation. DO and TDG quality control measurements were recorded for later reference. After the completion of the study, measurements from the field sondes were checked against a replicate instrument.

Prior to sampling, the turbine intake data sondes were serviced and calibrated. The two YSI 600 XLM DO sondes were inserted into the flow chambers at the turbine water intakes of $\mathrm{MG}_{3}$ and MG6. The meters were recalibrated and compared to measurements from a replicate instrument. The data collected during sonde servicing were recorded on a standard datasheet for later reference. Flow chambers were checked for sufficient flow before replacing the sondes. 


\section{RESULTS AND DISCUSSION}

The following sections present the results for each study parameter. Data are presented for the 2005 study and compared to previous study year results. In addition, DO enhancements for the two turbine designs are compared. Improvements noted during the course of the study provide empirical justification for turbine modifications at the Osage Project.

\section{III.A. Water Temperature}

Water temperature is an important variable to consider when evaluating aeration performance. The performance of an aeration device is largely driven by the difference between DO saturation and initial (intake) DO concentrations, which represents the aeration "driving force". Therefore, aeration performance is influenced by water temperature since DO saturation concentration increases with decreasing temperature. An aeration device should entrain greater oxygen mass at lower water temperatures (higher DO saturation concentration) if all other parameters are equal (i.e., initial DO concentration, airflow, etc.). Some aeration calculations are adjusted to standard conditions $\left(20^{\circ} \mathrm{C}\right)$; however, other calculations typically used to evaluate turbine aeration performance are not standardized. Therefore, the potential influence of water temperature should be considered when evaluating these measurements of aeration performance.

Annual temperature variability in Osage Project discharges are explained by lake mechanisms. Timing of reservoir stratification is the major factor that influences summer discharge water temperature. The temperature of the hypolimnion is primarily driven by timing of stratification, with earlier stratification resulting in cooler hypolimnetic temperatures. Therefore, earlier stratification results in cooler summer Osage Project discharges since the hypolimnion is the primary discharge water source,

\section{III.A.1. Water Temperature - 2005}

Temperature data were recorded in the discharge water from both study turbines in 2005. Discharge temperature from both units ranged from approximately 25 to $27^{\circ} \mathrm{C}$. Discharge water temperature increased with increasing tailrace and gate setting. Increasing tailrace elevation is directly related to total Project discharge, while individual turbine discharge is directly related to gate setting. Near-field reservoir stratification is somewhat destabilized as Project and individual turbine discharge increases. This results in withdrawal of warmer metalimnetic water rather than solely withdrawing from the hypolimnion (deep, cool layer). Therefore, discharge temperature increases as flow rates increase.

\section{III.A.2. Water Temperature Comparison of Study Years}

Study results from 2002 and 2005 are directly comparable without temperature compensation due to similar water temperatures. Discharge water temperatures were nearly identical during the 2002 and 2005 study conditions, ranging from 24 to $26^{\circ} \mathrm{C}$ and 24 to $27^{\circ} \mathrm{C}$, respectively. However, comparison of the 2002 and 2005 results to the 2003 results may be more complicated since discharges were cooler during the 2003 study, ranging from 18 to $21^{\circ} \mathrm{C}$. Cooler 2003 discharges are explained by the observed earlier onset of stratification and resulting cooler hypolimnion. The difference in DO saturation concentrations between 2003 and the other study years is approximately $1 \mathrm{mg} / \mathrm{L}$, representing a difference between intake and saturation DO (driving force) of 
approximately $15 \%$. The differences in aeration performance were potentially caused by the temperature differences in 2002, 2003 and 2005, for which discharge DO concentrations were well below saturation. However, these differences are likely within the range of instrument accuracy and sampling representativeness, which makes the influence of temperature between 2003 and the remaining study years difficult to discern.

\section{III.B. Airflow}

Airflow is a measure of the amount of air passing through the venting system over a given period of time. Each of the Osage Project's eight main generating units is equipped with some type of venting system to enhance discharge DO conditions. Airflow measurements were performed during all turbine tests since aeration performance is directly related to this critical parameter. Air temperature and barometric pressure were also measured in the turbine barrel and draft tube areas of MG6 and $\mathrm{MG}_{3}$ for conversion of airflow readings to standard atmospheric conditions. The volume of airflow may also be compared to the discharge rate, expressed as the air:discharge ratio. Air:discharge ratios provide a means of comparing the relationship of airflow and discharge using one value. This ratio is typically considered an important parameter for venting turbines. The following sections present airflow results from various venting and discharge configurations.

\section{III.B.1. Main Generator 6 Airflow - 2005}

Turbine intake airflow was measured at MG6 for each operating scenario with three different venting configurations: 1) four new main vents open and draft tube vent closed; 2) four new main vents open and draft tube vent open; and 3) four new main vents closed and draft tube vent open. The original two main vents were open during all operating scenarios and vent configurations at MG6, however, they did not contribute significantly to total airflows. Airflow data for MG6 are presented as Figures 5 through 7 illustrated by vent configuration and as Figures 8 through 11 illustrated by tailrace.

Airflow for all vent configurations decreased with increasing tailrace elevation at corresponding gate settings (Figures 5 through 7). MG6 operated with only the draft tube vents open exhibited the greatest range of decrease. At tailrace 553 and gate setting of $60 \%$ airflow was $12,400 \mathrm{scfm}$ while the same gate setting at 563 tailrace elevation produced minimal airflow (Figure 5). In contrast, MG6 with only the new main vents open had the least change in airflow over the range of tailrace elevations, with a change of approximately 3,000 to 5,000 scfm from tailrace elevation 553 to 563 at 40 to $85 \%$ gate settings (Figure 6 ). With this vent configuration, airflow was similar at 560 and 563 tailrace elevations for all gate settings with the new main vents.

Use of the new main vents and draft tube vents individually produced opposite relationships between airflow and discharge (Figures 9 to 11). Airflow through the new main vents decreased with increasing discharge, whereas airflow through the draft tube vent increased with increasing discharge. The draft tube vent produced greater airflow at low tailrace elevations $(553,556)$ for all gate settings. At higher tailrace elevations, the draft tube vent was only effective at the highest gate setting. The new main vents produced greater airflow at the low gate settings at tailrace elevations 560 and 563 . 
The combination of the new main vents and the draft tube vents produced the greatest amount of total airflow for all MG6 configurations of gate settings and tailrace elevations (Figures 8 to 11). The differing relationships between airflow and discharge for the new main vents and draft tube vent resulted in enhanced airflow when used in combination. Essentially, one vent system was effective when the other was not, producing significant aeration capacities through most operating ranges. Airflow was greatest at 556 tailrace $60 \%$ gate $(10,500 \mathrm{scfm})$ when MG6 was operated with both vent modifications. Airflow at this tailrace and gate setting was approximately $1,000 \mathrm{scfm}$ greater that the draft tube vent operating solely and 6,000 scfm greater than the new main vents operating solely. Airflow was only measured at one point for draft tube and new main vents at tailrace 553, which was comparable to the other vent configurations.

III.B.2. Main Generator 6 Airflow - Comparison of Study Years

MG6 was operated with various vent configurations during the 2002, 2003 and 2005 studies. The 2002 and 2003 studies were conducted with similar venting systems comprised of ten temporary (manual) auxiliary vents. However, the 2005 study was conducted with an automated vent system in place which employed four new main vents and a draft tube door baffle with a 16" vent pipe. The two original main vents were open throughout all study years and vent configurations. During 2002 and 2003 studies airflow was collected manually using handheld pitot tubes and manometers; however, in 2005 fixed position air velocity transmitters were mounted within the vents. Data collected by the air velocity transmitters were logged by Ameren's SCADA system. The fixed position transmitters improved measurement accuracy.

Airflow through the MG6 main vents generally increased each study year (Figures 12 through 15). Improvements from 2003 to 2005 were expected with the addition of four new main vents. Airflow with the auxiliary vents closed (AVC) was greater in 2003 than those observed in 2002 for all turbine scenarios. This increase resulted from upgrades performed to the MG6 nosecone (holes were enlarged and a baffle ring was installed) prior to the 2003 study. MG6 airflow was greater in 2005 with the four new main vents than in 2002 for all similar gate settings and tailrace elevations. However, airflows observed with the four new main vents in 2005 were only significantly different than those in 2003 at the 554 tailrace elevation. Airflow data collected at the remaining tailrace elevations were not appreciably different between the study years.

Airflow from the optimal vent configurations increased each study year (Figures 16 through 18). These configurations included use of the main and auxiliary vents during 2002 and 2003 and main and draft tube vents in 2005. The increase from 2002 to 2003 is again explained by modifications to the nosecone. The improvement observed in 2005 is attributed to complimentary venting capacity of the main and draft tube vents throughout the range of tailraces and discharges. 
III.B.3. Main Generator 3 Airflow - 2005

$\mathrm{MG}_{3}$ airflow was measured on the second day of sampling and for three different venting configurations: 1) four main vents open; 2) two main vents open; and 3) one main vent open. $\mathrm{MG}_{3}$ airflow and discharge data for the 2005 study year are depicted in Figures 19 through 21 for each vent configuration, while data for each tailrace are presented in Figures 22 through 24. Airflows ranged from 7,600 scfm to 2,500 scfm through four main vents, $6,900 \mathrm{scfm}$ to $2,500 \mathrm{scfm}$ through two main vents and from 4,700 to $2,100 \mathrm{scfm}$ through one main vent.

Airflow through two and four main vents was similar for all tailrace elevations and gate settings, indicating that vent capacity is not typically limiting airflow. The greatest difference between the four and two main vent scenarios occurred at 556 tailrace elevation at gate settings of 40 and $60 \%$ (Figure 22). All vent configurations yielded similar airflows at the highest tailrace elevation regardless of gate setting (Figure 24).

MG3 air: discharge ratios were similar for the four and two vent configurations throughout the study, but were only slightly depressed at tailrace 553 for the one main vent configuration.

\section{III.B.4. Main Generator 3 Airflow - Comparison of Study Years}

Relatively minor turbine modifications were made to $\mathrm{MG}_{3}$ during the study years. The most notable modification was the removal of the nosecone bottom plate prior to the 2003 study. Vent check valves were removed prior to 2005 testing. Airflow data collected during the three study years are presented in Figures 25 to 27.

Airflow was most notably improved by removal of the nosecone bottom plate as suggested by increased airflow from 2002 to 2003. MG3 airflow was particularly greater at moderate to high gate settings. The most significant increase occurred at tailrace 556 which averaged approximately 1,000 scfm for all gate settings (Figure 25). The 2003 and 2005 airflow data are relatively similar at all gate settings and tailrace elevation. Therefore, the removal of check valves from the four main vent pipes in 2005 apparently had little effect on airflow. This observation is also corroborated by the similar airflows with 2 and 4 vents open in 2005. Both observations suggest that airflow is not limited by vent capacity. Airflow is more likely limited by dynamics within the turbine as indicated by increased airflow with nosecone bottom plate removal.

\section{III.B.5. Main Generators 3 and 6 Airflow Comparison - 2005}

MG 6 operating with the draft tube and new main vents produced greater airflow than MG 3 operating with four main vents at low tailrace elevations (Figure 28). However, MG6 and MG 3 exhibited similar airflows at low to moderate gate settings ( 40 to $60 \%$ ) and moderate to high tailrace elevations (560-563) (Figures 29 and 30). MG3 operating with four main vents provided greater airflow at the high gate setting $(85 \%)$ and moderate to high tailrace elevations. 


\section{III.C. Dissolved Oxygen}

Dissolved oxygen is the concentration of gaseous oxygen entrained in a liquid and is essential for survival of aquatic life. It can be measured in various ways, for these studies it was measured using a rapid pulse DO probe. The results of DO measurements collected in the discharge waters of the Osage Project are described in the following sections.

\section{III.C.1. Main Generator 6 Dissolved Oxygen - 2005}

Turbine discharge DO concentrations typically decreased for all MG6 vent configurations with increasing tailrace elevation and discharge (Figures 31 to 34). The main exception to this observation was the draft tube vent only configuration at high tailrace elevations (560 and 563). At these operational settings, MG6 discharge DO increased with discharge, which is verified by higher airflows with increased discharge at the tailrace conditions.

During the 2005 study, MG6 discharge DO ranged from 2.60 to $7.52 \mathrm{mg} / \mathrm{L}$ (Tables 2 and 3) with the lowest DO recorded at tailrace $560,85 \%$ gate, with only the new main vents in operation. The highest reading was recorded at tailrace $553,20 \%$ gate using the draft vent only. The four new main vent $D O$ readings ranged from 2.6 to $7.4 \mathrm{mg} / \mathrm{L}$, draft tube vent only DO levels were 2.8 to $7.5 \mathrm{mg} / \mathrm{L}$, while the combination of the two yielded DO concentrations of 3.7 to $7.1 \mathrm{mg} / \mathrm{L}$. DO was typically above the $5 \mathrm{mg} / \mathrm{L}$ criterion at tailrace elevations below $560 \mathrm{ft}$. MSL. 
Table: 2

Summary of 2005 Discharge Dissolved Oxygen Concentration Data (7/26/05)

\begin{tabular}{|c|c|c|c|c|c|c|c|c|}
\hline \multirow[b]{3}{*}{$\begin{array}{c}\text { Tailrace } \\
\text { Elev. } \\
\text { (feet) }\end{array}$} & \multirow[b]{3}{*}{$\begin{array}{c}\text { Gate } \\
\text { Setting } \\
(\%)\end{array}$} & \multicolumn{3}{|c|}{ Vent Configurations } & \multirow{2}{*}{\multicolumn{2}{|c|}{ Discharge (cfs) }} & \multirow{2}{*}{\multicolumn{2}{|c|}{$\begin{array}{c}\text { Dissolved Oxygen } \\
(\mathrm{mg} / \mathrm{L})\end{array}$}} \\
\hline & & \multicolumn{2}{|c|}{ MG6 } & \multirow{2}{*}{$\begin{array}{c}\text { MG3 } \\
\\
\text { \# of Main } \\
\text { Vents Open }\end{array}$} & & & & \\
\hline & & $\begin{array}{l}\text { Draft } \\
\text { Tube } \\
\text { Vent }\end{array}$ & $\begin{array}{l}\text { New } \\
\text { Main } \\
\text { Vents }\end{array}$ & & MG6 & MG3 & MG6 & MG3 \\
\hline 556 & $40 \%$ & Open & Closed & 4 & 1,800 & 1,784 & 5.54 & 5.95 \\
\hline 556 & $40 \%$ & Open & Open & 2 & 1,800 & 1,784 & 5.59 & 5.98 \\
\hline 556 & $40 \%$ & Closed & Open & 1 & 1,800 & 1,784 & 5.35 & 5.53 \\
\hline 556 & $60 \%$ & Closed & Open & 1 & 2,796 & 2,760 & 4.43 & 4.72 \\
\hline 556 & $60 \%$ & Open & Open & 2 & 2,796 & 2,760 & 5.73 & 5.20 \\
\hline 556 & $60 \%$ & Open & Closed & 4 & 2,796 & 2,760 & 5.48 & 5.50 \\
\hline 556 & $85 \%$ & Open & Closed & 3 & 4,136 & 4,185 & 4.87 & 4.69 \\
\hline 556 & $85 \%$ & Open & Open & 2 & 4,136 & 4,185 & 5.05 & 4.80 \\
\hline 556 & $85 \%$ & Closed & Open & 1 & 4,136 & 4,185 & 3.12 & 4.15 \\
\hline 560 & $40 \%$ & Open & Closed & 4 & 1,792 & 1,767 & 3.03 & 4.66 \\
\hline 560 & $40 \%$ & Open & Open & 2 & 1,792 & 1,767 & 4.95 & 4.86 \\
\hline 560 & $40 \%$ & Closed & Open & 1 & 1,792 & 1,767 & 4.7 & 4.29 \\
\hline 560 & $60 \%$ & Closed & Open & 1 & 2,780 & 2,745 & 4.05 & 4.01 \\
\hline 560 & $60 \%$ & Open & Open & 2 & 2,780 & 2,745 & 5.17 & 4.44 \\
\hline 560 & $60 \%$ & Open & Closed & 4 & 2,780 & 2,745 & 3.34 & 4.82 \\
\hline 560 & $85 \%$ & Open & Closed & 4 & 4,059 & 4,184 & 3.69 & 4.82 \\
\hline 560 & $85 \%$ & Open & Open & 2 & 4,059 & 4,184 & 3.7 & 4.61 \\
\hline 560 & $85 \%$ & Closed & Open & 1 & 4,059 & 4,184 & 2.6 & 4.02 \\
\hline 563 & $40 \%$ & Open & Open & 4 & 1,765 & 1,755 & 4.5 & 4.20 \\
\hline 564 & $40 \%$ & Open & Closed & 2 & 1,765 & 1,755 & 2.85 & 4.04 \\
\hline 563 & $40 \%$ & Closed & Open & 1 & 1,765 & 1,755 & 4.29 & 4.06 \\
\hline 563 & $60 \%$ & Closed & Open & 1 & 2,747 & 2,745 & 4.29 & 3.95 \\
\hline 563 & $60 \%$ & Open & Open & 2 & 2,747 & 2,745 & 4.84 & 4.86 \\
\hline 563 & $60 \%$ & Open & Closed & 4 & 2,747 & 2,745 & 3.33 & 4.57 \\
\hline 563 & $85 \%$ & Open & Closed & 4 & 3,980 & 4,179 & 3.78 & 4.47 \\
\hline 563 & $85 \%$ & Open & Open & 2 & 3,980 & 4,179 & 3.84 & 4.24 \\
\hline 563 & $85 \%$ & Closed & Open & 1 & 3,980 & 4,179 & 3.27 & 3.86 \\
\hline 563 & $85 \%$ & Closed & Closed & None & 3,980 & 4,179 & 3.34 & 3.36 \\
\hline 563 & $85 \%$ & Closed & Closed & None & 3,980 & 4,179 & 3.04 & 2.52 \\
\hline
\end{tabular}


Table: 3

Summary of 2005 Discharge Dissolved Oxygen Concentration Data $(7 / 27 / 05)$

\begin{tabular}{|c|c|c|c|c|c|}
\hline & & \multicolumn{2}{|c|}{$\begin{array}{c}\text { MG6 Vent } \\
\text { Configurations }\end{array}$} & \\
\cline { 3 - 6 } Tailrace \\
$\begin{array}{c}\text { Elev. } \\
\text { (feet) }\end{array}$ & $\begin{array}{c}\text { Gate } \\
\text { Setting } \\
(\%)\end{array}$ & $\begin{array}{c}\text { Draft } \\
\text { Tube } \\
\text { Vent }\end{array}$ & $\begin{array}{c}\text { New } \\
\text { Main } \\
\text { Vents }\end{array}$ & $\begin{array}{c}\text { MG6 } \\
\text { Discharge } \\
\text { (cfs) }\end{array}$ & $\begin{array}{c}\text { MG6 } \\
\text { Dissolved } \\
\text { Oxygen } \\
\text { (mg/L) }\end{array}$ \\
\hline 553 & $10 \%$ & Open & Closed & 409 & 6.80 \\
\hline 552 & $10 \%$ & Open & Open & 409 & 7.07 \\
\hline 552 & $10 \%$ & Closed & Open & 409 & 7.29 \\
\hline 552 & $20 \%$ & Closed & Open & 818 & 7.41 \\
\hline 552 & $20 \%$ & Open & Closed & 818 & 7.52 \\
\hline 552 & $30 \%$ & Open & Closed & 1,260 & 6.94 \\
\hline 552 & $30 \%$ & Closed & Open & 1,260 & 6.59 \\
\hline 552 & $40 \%$ & Closed & Open & 1,758 & 6.29 \\
\hline 552 & $40 \%$ & Open & Closed & 1,758 & 6.67 \\
\hline 552 & $50 \%$ & Open & Closed & 2,239 & 6.44 \\
\hline 553 & $50 \%$ & Closed & Open & 2,239 & 5.33 \\
\hline 553 & $60 \%$ & Closed & Open & 2,779 & 4.84 \\
\hline 553 & $60 \%$ & Open & Closed & 2,779 & 6.38 \\
\hline 553 & $70 \%$ & Open & Closed & 3,350 & 6.15 \\
\hline 553 & $70 \%$ & Closed & Open & 3,350 & 4.45 \\
\hline 553 & $80 \%$ & Closed & Open & 3,947 & 3.97 \\
\hline 553 & $80 \%$ & Open & Closed & 3,947 & 5.40 \\
\hline 553 & $90 \%$ & Open & Closed & 4,344 & 5.27 \\
\hline 553 & $90 \%$ & Closed & Open & 4,344 & 3.64 \\
\hline 553 & $90 \%$ & Closed & Closed & 4,344 & 2.42 \\
\hline 554 & $40 \%$ & Closed & Closed & 1,758 & 2.18 \\
\hline & & & & & \\
\hline
\end{tabular}

The maximum DO levels for all three vent configurations occurred at low tailrace and gate settings. Minimum DO values were recorded at tailrace 560 and $85 \%$ gate for new main vents and the combination of new main vents and the draft tube vent, while the draft tube vent alone exhibited a minimum DO occurring at 563 and $40 \%$ gate.

As seen with airflow, the relationship between DO and discharge at high tailrace elevations were opposite for the new main vents and the draft tube vent only. The new main vent configuration resulted in higher DO levels at the lower gate settings, while the draft tube vent produced higher DO levels as discharge increased. The draft tube only scenario produced DO concentrations equal to the combination of the new main vents and the draft tube vent at $85 \%$ gate for 560 and 563 tailrace elevations. When operated together, the new main vents and draft tube vent were most effective at the $60 \%$ gate settings. 
III.C.2. Main Generator 6 Dissolved Oxygen - Comparison of Study Years In addition to vent airflow, turbine discharge DO levels may be influenced by intake water temperature and DO concentration. As discussed earlier, aeration performance is greater at lower water temperature since DO saturation increases with decreasing temperature. Also, discharge DO increases with initial (intake) DO concentrations. As previously discussed, water temperatures were very similar in 2002 and 2005 and markedly cooler $\left(5^{\circ} \mathrm{C}\right)$ in 2003 . The cooler intake temperature in 2003 was due to earlier stratification which set the hypolimnetic temperature cooler than in 2002 and 2005 . The cooler 2003 hypolimnetic temperature represented stronger reservoir stratification, which in turn limited the withdrawal of warmer and more oxygenated metalimnetic water during high discharges. Maximum intake DO concentrations during 2002 and 2005 were quite similar (1.1-1.2 mg/L), whereas maximum intake DO in 2003 was 0.5 $\mathrm{mg} / \mathrm{L}$. The 2003 intake conditions represent conflicting variables on aeration performance. While lower intake temperature increases aeration efficiency, lower intake DO reduces discharge DO. Since these factors potentially counteract each other in this instance, the 2003 data are likely comparable to the 2002 and 2005 data particularly considering the inherent variability resulting from instrument accuracy and sampling representativeness.

In all study years, discharge DO concentrations with the main vent configuration decreased with increasing tailrace elevations and discharge (Figures 35 to 38). These observations were based upon use of the two original main vents during 2002 and 2003 and operation of the four new main vents in 2005. Dissolved oxygen was greater during 2003 than 2002 for all gate settings and tailrace elevations below 563. In 2003, DO levels at tailrace elevation 563 were less than those observed at similar gate settings in 2002 . The 2005 DO concentrations for MG6, operating with four new main vents, were greater than 2002 and 2003, operating with the two original main vents for all tailrace elevations. For these vent configurations, airflow during 2005 was similar to 2003 so the higher 2005 discharge DO levels at high tailrace elevations were likely due to higher intake DO conditions

Discharge DO concentrations for 2002 and 2003 with main and auxiliary vents open are compared to those observed during 2005 both draft tube and four new main vents (Figures 39 to 41). DO levels in 2003 were higher than in 2002 with the same venting configuration, at tailrace elevations 557 and 560. However, $2002 \mathrm{DO}$ levels were greater than in 2003 at tailrace elevation 563, again potentially due to higher intake DO levels. The 2005 data demonstrate that MG6 discharge DO concentrations improved markedly with these vent configurations as compared to the 2002 and 2003 data.

DO concentrations observed in the discharge of MG6 had significant increases from the unit's conventional venting system. Table 4 describes the increases in DO levels measured with the two original main vents in 2002 and both draft tube and new main vents in 2005. Concentrations increased an average of $1.9 \mathrm{mg} / \mathrm{L}$ from 2002 to 2005 with the greatest gain occurring at the low tailrace, high gate setting configuration. 
MEC Water Resources, Inc.

Osage Project Supplemental Turbine Testing Report

Table 4: Main Generator 6 Discharge Dissolved Oxygen Enhancement

from 2002 to 2005

\begin{tabular}{|c|c|c|c|c|c|c|c|c|c|}
\cline { 2 - 10 } \multicolumn{1}{c|}{} & \multicolumn{9}{c|}{ Discharge Dissolved Oxygen (mg/L) } \\
\cline { 2 - 10 } \multicolumn{1}{c|}{} & \multicolumn{4}{c|}{2002} & \multicolumn{3}{c|}{2005} & \multicolumn{3}{c|}{ Difference (2005-2002) } \\
\hline \multirow{2}{c}{$\begin{array}{c}\text { Tailrace Elevation } \\
\text { (ft. MSL) }\end{array}$} & \multicolumn{3}{c|}{ Gate Setting } & \multicolumn{3}{c|}{ Gate Setting } & \multicolumn{3}{c|}{ Gate Setting } \\
\cline { 2 - 11 } & $40 \%$ & $60 \%$ & $80 \% \& 90 \%$ & $40 \%$ & $60 \%$ & $85 \%$ & $40 \%$ & $60 \%$ & $85 \%$ \\
\hline 556 & 3.90 & 3.11 & 2.04 & 5.59 & 5.73 & 5.05 & 1.69 & 2.62 & 3.02 \\
\hline 560 & 3.01 & 3.05 & 2.00 & 4.95 & 5.17 & 3.70 & 1.94 & 2.12 & 1.71 \\
\hline 563 & 3.61 & 3.28 & 2.60 & 4.50 & 4.84 & 3.84 & 0.89 & 1.56 & 1.25 \\
\hline
\end{tabular}

Discharge DO concentrations for 2002 were typically above the DO criterion of $5 \mathrm{mg} / \mathrm{L}$ at tailrace elevation 552 and for several of the lower gate settings at tailrace elevations 554, 557 and 560 (Appendix 2 , Tables 2 and 3). Discharge DO levels at tailraces 560 and 563 were typically below the DO criterion. The DO criterion was achieved in discharge water at tailraces 552 and 554 at 1 megawatt gate settings, all other gate settings and tailrace elevations yielded DO levels below the criterion (Appendix 2, Table 5). Discharge DO levels in 2005 were greater than $5 \mathrm{mg} / \mathrm{L}$ at tailrace elevations below 560 with the exception of the four new main vent configuration (Appendix 2, Table 6). The four new main vents operating alone produced $\mathrm{DO}$ concentrations below the criterion at tailraces and gate settings above 553 and 60\%, respectively.

III.C.3. Main Generator 3 Dissolved Oxygen - 2005

Discharge DO levels from $\mathrm{MG}_{3}$ were relatively similar for the two and four main vent configurations (Figures 42 through 44). Discharge DO concentrations from the four vent configuration ranged from 4.2 to $6.0 \mathrm{mg} / \mathrm{L}$ (Table 2 ), with minimums occurring at $40 \%$ gate and 563 tailrace and maximums occurring at $40 \%$ gate and 556 tailrace elevations. The two vent configuration resulted in discharge DO values of 4.0 and $6.0 \mathrm{mg} / \mathrm{L}$. Maximums and minimums were recorded at the same gate settings and tailrace elevations as the four vent configuration. Discharge DO values for two and four vents were above the DO criterion for $40 \%$ and $60 \%$ gate settings at 556 tailrace elevations, with the remainder of the configurations yielded DO levels less than $5 \mathrm{mg} / \mathrm{L}$.

Discharge DO levels observed with one main vent open were lower than the four and two vent configurations throughout the testing. One main vent $D O$ readings ranged from 3.9 to $5.5 \mathrm{mg} / \mathrm{L}$. Maximum values were observed at $40 \%$ gate at tailrace 556 while minimums occurred at the highest gate and tailrace configurations. At the highest tailrace elevation (563), discharge DO levels were similar for all gate settings. One main vent produced a similar comparison regarding the DO criterion as two and four main vents.

\section{III.C.4. Main Generator 3 Dissolved Oxygen - Comparison of Study Years}

DO concentrations for 2002 were less than those observed in 2003 and 2005 at all turbine configurations (Figures 45 through 47). The 2005 discharge DO concentrations were similar to 2003 values at tailrace 556 for all gate settings and at low gate settings for the higher tailrace elevation. At higher tailrace elevations and gate settings, 2005 DO concentrations were greater than those observed during 2003. The higher discharge DO concentrations observed at the higher tailraces and gate settings in 2005 were likely due to lower 2003 intake DO concentrations. 
$\mathrm{DO}$ enhancement modifications performed on $\mathrm{MG}_{3}$ produced an average gain in DO concentrations of $1.4 \mathrm{mg} / \mathrm{L}$ (Table 5). DO levels had the greatest gains at the moderate to high gate settings for all tailrace elevations.

Table 5: Main Generator 3 Discharge Dissolved Oxygen Enhancement from 2002 to 2005

\begin{tabular}{|c|c|c|c|c|c|c|c|c|c|}
\cline { 2 - 10 } \multicolumn{1}{c|}{} & \multicolumn{4}{c|}{ Discharge Dissolved Oxygen (mg/L) } \\
\cline { 2 - 10 } \multicolumn{1}{c|}{} & \multicolumn{4}{c|}{2002} & \multicolumn{3}{c|}{2005} & \multicolumn{3}{c|}{ Difference (2005-2002) } \\
\hline \multirow{2}{c|}{$\begin{array}{c}\text { Tailrace Elevation } \\
\text { (ft. MSL) }\end{array}$} & \multicolumn{3}{|c|}{ Gate Setting } & \multicolumn{3}{c|}{ Gate Setting } \\
\cline { 2 - 10 } & $40 \%$ & $60 \%$ & $80 \% \& 90 \%$ & $40 \%$ & $60 \%$ & $85 \%$ & $40 \%$ & $60 \%$ & $85 \%$ \\
\hline 556 & 5.02 & 4.10 & 3.12 & 5.95 & 5.50 & 4.69 & 0.93 & 1.40 & 1.57 \\
\hline 560 & 3.63 & 3.21 & 2.60 & 4.66 & 4.82 & 4.82 & 1.03 & 1.61 & 2.22 \\
\hline 563 & 3.49 & 3.39 & 2.92 & 4.20 & 4.57 & 4.47 & 0.71 & 1.18 & 1.56 \\
\hline
\end{tabular}

Discharge DO concentrations during the three study years were typically above the DO criterion (5 mg/L) when tailrace elevations were below 560 (Appendix 2, Tables 1, 4 and 7). DO levels in 2002 went below $5 \mathrm{mg} / \mathrm{L}$ when gate settings were $80 \%$ at tailrace elevation 554 with the exception of the lowest gate settings at tailrace 557 .

III.C.5. Main Generator 3 and 6 Dissolved Oxygen Comparison - 2005 Dissolved oxygen followed a similar pattern as airflow when comparing MG6 draft tube and new main vents to $\mathrm{MG}_{3}$ four main vent configurations (Figures 48 to 50 and Table 6). However, increased DO produced by greater MG6 airflows at low tailrace and moderate to high gate settings was marginal. Observed DO increases were within the margin of accuracy of the test method. Discharge DO from $\mathrm{MG}_{3}$ was more consistent with increasing gate setting than MG6 and provided greater DO at high gate settings and moderate to high tailrace elevations. These discharge $\mathrm{DO}$ increases ranged from 0.6 to $1.1 \mathrm{mg} / \mathrm{L}$.

Table 6: Main Generators 3 and 6 Discharge Dissolved Oxygen Comparison - 2005

\begin{tabular}{|c|c|c|c|c|c|c|c|c|c|}
\hline & \multicolumn{9}{|c|}{ Discharge Dissolved Oxygen (mg/L) } \\
\hline & \multicolumn{3}{|c|}{$M G_{3}$} & \multicolumn{3}{|c|}{ MG6 } & \multicolumn{3}{|c|}{ Difference } \\
\hline \multirow{2}{*}{$\begin{array}{c}\text { Tailrace Elevation } \\
\text { (ft. MSL) }\end{array}$} & \multicolumn{3}{|c|}{ Gate Setting } & \multicolumn{3}{|c|}{ Gate Setting } & \multicolumn{3}{|c|}{ Gate Setting } \\
\hline & $40 \%$ & $60 \%$ & $85 \%$ & $40 \%$ & $60 \%$ & $85 \%$ & $40 \%$ & $60 \%$ & $85 \%$ \\
\hline 556 & 5.95 & 5.5 & 4.69 & 5.59 & 5.73 & 5.05 & 0.36 & -0.23 & -0.36 \\
\hline 560 & 4.66 & 4.82 & 4.82 & 4.95 & 5.17 & 3.70 & -0.29 & -0.35 & 1.12 \\
\hline 563 & 4.2 & 4.57 & 4.47 & 4.50 & 4.84 & 3.84 & -0.30 & -0.27 & 0.63 \\
\hline
\end{tabular}

*** Negative values indicated that MG6 DO was greater than MG3. 


\section{III.D. Aeration Performance}

Various relationships can be established using turbine discharge, airflow, and DO data collected during testing of the study units. These relationships may be used to guide design criteria for future aeration enhancements. Several equations have been developed to allow comparison of aeration data and are described below.

The DO concentration increase attributed to turbine aeration is determined by subtracting the intake $D O$ concentration $\left(C_{L}\right)$ from the discharge concentration $\left.C_{D}\right)$,.

$$
\text { DO increase }=C_{D}-C_{L}
$$

Aeration efficiency is measurement of a study unit's ability to increase the discharge DO concentration to saturation at a given operational scenario. This value accounts for varying temperatures between data sets, since DO saturation is related to water temperature. This calculated value is also closely related to DO increase since the calculation serves as the numerator. Aeration efficiency is calculated by dividing DO increase $\left(C_{D}-C_{i}\right)$ by the difference between the saturation concentration $\left(C_{S}\right)$ of oxygen and the intake $\mathrm{DO}$ concentration $\left(\mathrm{C}_{\mathrm{i}}\right)$ or $\mathrm{C}_{\mathrm{s}}-\mathrm{C}_{\mathrm{i}}$.

$$
\text { Aeration efficiency }=\frac{\left(C_{D}-C_{i}\right)}{\left(C_{S}-C_{i}\right)}
$$

Oxygen transfer efficiency (OTE) is a measure of a unit's ability to transfer oxygen vent air into the turbine discharge. OTE is defined as the percentage of the available oxygen in the airflow that dissolves into the turbine discharge. This value is calculated by dividing the mass of the oxygen transferred to the water by the mass of the oxygen passing through the vent.

$$
\mathrm{OTE}=\frac{{\text { mass } \mathrm{O}_{2}}_{2}(\mathrm{lbs}) \text { transferred to discharge water }}{\text { mass of } \mathrm{O}_{2}(\mathrm{lbs}) \text { from airflow }}
$$

\section{III.D.1. Aeration Performance - 2005}

MG6 and MG3 DO increase values show a similar trends with air:discharge ratio for all configurations (Figure 51). The relationship between DO increase and air:discharge ratio was essentially linear between air:discharge ratios of 0.00 and 0.07 . DO increase exceeded the $5 \mathrm{mg} / \mathrm{L}$ water quality criterion for both units primarily when air: discharge ratios exceeded 0.05 , while DO increase was not greatly influenced by air: discharge ratios greater than 0.10 .

As with other study years, calculated DO increase was approximately $2 \mathrm{mg} / \mathrm{L}$, when very little or no venting airflow was provided. These observations may only be explained by misrepresentative intake DO sampling, inaccurate intake DO monitoring, and/or aeration that occurs within the turbulent boil area. Intake DO could be underestimated if water flow is stratified within the intake and disproportionate sampling occurs, such as sampling of the cooler, anoxic bottom strata within the intake. DO monitoring of relatively anoxic conditions is very challenging since calibration is performed at saturated conditions rather than test conditions and hydrogen sulfide, which is typically found to some extent in anoxic environments, may also interfere with dissolved oxygen 
measurements. Lastly, the turbine boil is quite turbulent, particularly at high discharges (gate settings, which could result in aeration within the boil.

DO increase ranged from 2.1 to $2.2 \mathrm{mg} / \mathrm{L}$ during four tests when MG6 turbine vents were closed. These tests were conducted at moderate to high gate settings ( $40 \%$ to $90 \%$ ) and low and high tailrace elevations (553 and 563). If misrepresentative sampling occurred, lower DO increase would be expected at lower study unit discharge (lower gate setting) and lower Project discharge (lower tailrace), as reservoir stratification would be less disturbed and less metalimnetic water would be withdrawn. However, the MG6 DO increase was consistent between these discharge scenarios. MG3 DO increase during no venting at a high gate setting (85\%) and tailrace elevation (563) ranged from 0.7 to 1.4 $\mathrm{mg} / \mathrm{L}$. During no venting runs, discharge temperature was similar to recorded intake temperature at MG6 (moderate to high gate setting and low tailrace) and at MG3 no venting, (high gate setting and tailrace), suggesting representative intake sampling since oxygenated metalimnetic water would be warmer than anoxic hypolimnetic water. However, MG6 discharge temperature was approximately $1.4{ }^{\circ} \mathrm{C}$ warmer than recorded intake temperature during the high gate setting, high tailrace no venting testing. These observations do not demonstrate that any one factor is responsible for the recorded DO increases with no venting, suggesting that all factors discussed above may influence these observations.

A clear correlation between aeration efficiency and air: discharge ratio was observed when all turbine testing data are compared (Figure 52). Aeration efficiency shares a similar relationship as DO increase to air: discharge ratio since the parameter is calculated using the observed DO increase and water temperature does not vary significantly between test scenarios. As with DO increase, aeration efficiency is not appreciably influenced by air:discharge ratios greater than 0.10 .

Calculated OTE (percentage of oxygen dissolved in discharge water) decreased as air: discharge ratio increased (Figure 53). Air:discharge ratios less than 0.05 had the greatest influence on OTE, with diminishing return for additional airflow at ratios greater than 0.10 .

\section{III.D.2. Aeration Performance - Comparison of Study Years}

DO increase was similar for 2005 and 2003, with both years showing a strong relationship to air: discharge ratios (Figure 54). The $2002 \mathrm{DO}$ increase data were more scattered, particularly at higher air: discharge ratios when greater variation was observed in all datasets. The 2002 deviations could be attributed to the methods used to collect airflow in 2002. DO Increase for 2003 began to deviate from the group when air to discharge ratios reach 0.06 . Relationships between air: discharge ratio and DO increase in 2005 were more consistent than 2002 and 2003 at higher air: discharge ratios. The better 2005 correlation may be explained by the more accurate airflow measurement techniques used in 2005, particularly at high airflows (high velocity) when measurement errors are magnified. Net DO transfer exceed $5 \mathrm{mg} / \mathrm{L}$ at air: discharge ratios of 0.05 relatively consistently between study years.

The relationship between aeration efficiency and air: discharge ratio exhibited a similar pattern as DO increase due to its dependency on DO transfer (Figure 55). Again, the 2002 and 2003 relationships are scattered above air: discharge ratios of 0.06 . The 2005 
data follow a much more consistent relationship throughout the range of air: discharge ratios. Data for all years were similar at air: discharge ratios of less than 0.05

Observations of OTE during all study years showed a consistent relationship with air: discharge ratio, regardless of the study turbine or vent configuration (Figure 56). These observations indicate that OTE is closely related to the air: discharge relationship, the driving factor in the aeration of discharge water. OTE decreases sharply with air:discharge ratios from o to 0.10 . An inflection point is reached when air: discharge ratios exceed 0.10 , indicating a point of diminishing return for additional aeration past this point.

\section{III.E. Total Dissolved Gas}

Total dissolved gas is the sum of the partial pressures of gases in water, consisting primarily of nitrogen and oxygen. TDG is increased with aeration, particularly when atmospheric air is used as the oxygen source since additional nitrogen is dissolved in water along with oxygen. TDG is an important parameter when considering aeration systems because excessive levels of TDG can be detrimental to aquatic life, leading to gas bubble disease. The Missouri TDG water quality criterion for protection of aquatic life is $110 \%$ of the saturation partial pressure. TDG is measured using the membrane diffusion method which employs a pressure transducer and a gas membrane tube that is permeable to all gases as well as water vapor. As dissolved gases pass through the tubing the sum of their pressures is measured by a pressure transducer resulting in a measurement of TDG pressure. Percent saturation can then be calculated dividing the TDG by the barometric pressure. The following paragraphs describe the observations recorded in the discharge water of MG6 and MG3 throughout the study years.

\section{III.E.1. Total Dissolved Gas - 2005}

TDG concentrations were typically highest at the low tailrace elevations and discharge rates since greater aeration occurs at these operational scenarios. As tailrace and discharge rates increased, TDG decreased (Table 7). For the configuration of MG6 with the new main vents operating, TDG measurements ranged from $92 \%$ at the tailrace elevation 563 and a discharge of $4200 \mathrm{cfs}$, while the maximum value of $121 \%$ was measured at tailrace elevation 553 and a discharge of $706 \mathrm{cfs}$. For MG6 operating with draft tube vent, TDG values ranged from $120 \%$ at tailrace elevation 553 and a discharge of $694 \mathrm{cfs}$ and $95 \%$ at tailrace elevation 563 with a discharge of 1,810 cfs. TDG levels discharged by MG6 with the draft tube and main vents open ranged from 98 to $118 \%$, with the $110 \%$ criterion exceeded in $60 \%$ of scenarios and until high gate setting (85\%) and high tailrace (560') was reached. For MG3, TDG maximum values were $115 \%$ at tailrace elevation 556 and 1,788 cfs discharge ( 2 main vents) and at tailrace 556 with2,600 cfs discharge (4 main vents). The minimum of $102 \%$ was observed at tailrace elevation 563 and with 4,000 cfs discharge with one main vent open.

TDG increased with air: discharge ratio, typically exceeding $110 \%$ when air: discharge ratios reached 0.05 regardless of turbine or vent configuration (Figure 56). Air: discharge ratios had little affect on TDG after 0.10 , similar to DO observations. Figures 57 and 58 illustrate the relationship between TDG and dissolved oxygen values. The TDG criterion of $110 \%$ was generally exceeded after the DO water quality criterion of $5 \mathrm{mg} / \mathrm{L}$ and a DO increase of $4.5 \mathrm{mg} / \mathrm{L}$ was exceeded 
MEC Water Resources, Inc.

Osage Project Supplemental Turbine Testing Report

Table 7: Total Dissolved Gas - 2005

\begin{tabular}{|c|c|c|c|c|c|c|c|c|c|c|c|}
\hline \multirow{2}{*}{ Run \# } & \multirow{2}{*}{$\begin{array}{c}\text { Gate } \\
\text { Setting } \\
(\%)\end{array}$} & \multirow{2}{*}{$\begin{array}{c}\text { Tailrace } \\
\text { Elevation } \\
\text { (ft) }\end{array}$} & \multicolumn{2}{|c|}{ Unit Load (MW) } & \multirow{2}{*}{$\begin{array}{c}\text { MG 6 } \\
\text { Draft } \\
\text { Tube } \\
\text { Vents }\end{array}$} & \multirow{2}{*}{$\begin{array}{c}\text { MG } 6 \\
\text { New Main } \\
\text { Vents }\end{array}$} & \multirow{2}{*}{$\begin{array}{l}\text { MG 3 } \\
\text { Main } \\
\text { Vents } \\
\text { Open }\end{array}$} & \multicolumn{2}{|c|}{ Unit Discharge (cfs) } & \multicolumn{2}{|c|}{$\begin{array}{c}\text { Total Dissolved Gas } \\
\text { (\% Saturation) }\end{array}$} \\
\hline & & & MG 6 & MG 3 & & & & MG 6 & MG 3 & MG 6 & MG 3 \\
\hline \multicolumn{12}{|c|}{ August 27, 2005} \\
\hline 1 & $10 \%$ & 552.5 & 1 & --- & Open & Closed & $\overline{---}$ & 157 & --- & 117 & --- \\
\hline 2 & $10 \%$ & 552.5 & 1 & --- & Open & Open & --- & 166 & --- & 118 & --- \\
\hline 3 & $10 \%$ & 552.4 & 1 & --- & Closed & Open & --- & 156 & --- & 119 & --- \\
\hline 4 & $20 \%$ & 552.4 & 3 & --- & Closed & Open & --- & 706 & --- & 121 & --- \\
\hline 5 & $20 \%$ & 552.4 & 3 & --- & Open & Closed & --- & 694 & --- & 120 & --- \\
\hline 6 & $30 \%$ & 552.4 & 7 & --- & Open & Closed & --- & 1,279 & --- & 116 & --- \\
\hline 7 & $30 \%$ & 552.4 & 7 & --- & Closed & Open & --- & 1,276 & --- & 116 & --- \\
\hline 8 & $40 \%$ & 552.4 & 11 & --- & Closed & Open & --- & 1,841 & --- & 117 & --- \\
\hline 9 & $40 \%$ & 552.4 & 11 & --- & Open & Closed & --- & 1,838 & --- & 118 & --- \\
\hline 10 & $50 \%$ & 552.4 & 15 & --- & Open & Closed & --- & 2,394 & --- & 117 & --- \\
\hline 11 & $50 \%$ & 552.5 & 15 & --- & Closed & Open & --- & 2,374 & --- & 111 & --- \\
\hline 12 & $60 \%$ & 552.6 & 19 & --- & Closed & Open & --- & 2,934 & --- & 108 & --- \\
\hline 13 & $60 \%$ & 552.7 & 19 & --- & Open & Closed & --- & 2,971 & --- & 117 & --- \\
\hline 14 & $70 \%$ & 552.8 & 22 & --- & Open & Closed & --- & 3,559 & --- & 115 & --- \\
\hline 15 & $70 \%$ & 553.0 & 22 & --- & Closed & Open & --- & 3,581 & --- & 107 & --- \\
\hline 16 & $80 \%$ & 553.1 & 25 & --- & Closed & Open & --- & 4,181 & --- & 103 & --- \\
\hline 17 & $80 \%$ & 553.2 & 29 & --- & Open & Closed & --- & 4,114 & --- & 110 & --- \\
\hline 18 & $90 \%$ & 553.3 & 29 & --- & Open & Closed & --- & 4,353 & --- & 110 & --- \\
\hline 19 & $90 \%$ & 553.4 & 29 & --- & Closed & Open & --- & 4,381 & --- & 101 & --- \\
\hline 20 & $90 \%$ & 553.5 & 31 & --- & Closed & Closed & --- & 4,409 & --- & 94 & --- \\
\hline 21 & $40 \%$ & 553.5 & 15 & --- & Closed & Closed & --- & 1,928 & --- & 94 & --- \\
\hline \multicolumn{12}{|c|}{ August 26, 2005} \\
\hline 1 & $40 \%$ & 556.4 & 11 & 9 & Open & Closed & 4 & 1,826 & 1,779 & 113 & 108 \\
\hline 2 & $40 \%$ & 556.4 & 10 & 9 & Open & Open & 2 & 1,796 & 1,788 & 114 & 115 \\
\hline 3 & $40 \%$ & 556.3 & 11 & 9 & Closed & Open & 1 & 1,809 & 1,797 & 113 & 113 \\
\hline 4 & $60 \%$ & 556.2 & 19 & 16 & Closed & Open & 1 & 2,936 & 2,643 & 109 & 110 \\
\hline 5 & $60 \%$ & 556.2 & 18 & 15 & Open & Open & 2 & 2,904 & 2,611 & 115 & 114 \\
\hline 6 & $60 \%$ & 556.2 & 19 & 15 & Open & Closed & 4 & 2,957 & 2,600 & 115 & 115 \\
\hline 7 & $85 \%$ & 556.2 & 29 & 25 & Open & Closed & 3 & 4,301 & 3,932 & 111 & 111 \\
\hline 8 & $85 \%$ & 556.3 & 29 & 26 & Open & Open & 2 & 4,314 & 3,953 & 111 & 109 \\
\hline 9 & $85 \%$ & 556.4 & 30 & 27 & Closed & Open & 1 & 4,357 & 4,022 & 100 & 107 \\
\hline 10 & $40 \%$ & 560.2 & 10 & 8 & Open & Closed & 4 & 1,773 & 1,741 & 102 & 112 \\
\hline 11 & $40 \%$ & 560.3 & 10 & 8 & Open & Open & 2 & 1,781 & 1,750 & 113 & 115 \\
\hline 12 & $40 \%$ & 560.2 & 10 & 8 & Closed & Open & 1 & 1,786 & 1,757 & 111 & 109 \\
\hline 13 & $60 \%$ & 560.2 & 19 & 15 & Closed & Open & 1 & 2,940 & 2,612 & 106 & 107 \\
\hline 14 & $60 \%$ & 560.2 & 18 & 15 & Open & Open & 2 & 2,934 & 2,598 & 112 & 111 \\
\hline 15 & $60 \%$ & 560.3 & 20 & 15 & Open & Closed & 4 & 3,009 & 2,588 & 100 & 112 \\
\hline 16 & $85 \%$ & 560.2 & 28 & 25 & Open & Closed & 4 & 4,262 & 3,918 & 103 & 110 \\
\hline 17 & $85 \%$ & 560.0 & 28 & 26 & Open & Open & 2 & 4,297 & 3,945 & 102 & 110 \\
\hline 18 & $85 \%$ & 560.0 & 29 & 27 & Closed & Open & 1 & 4,284 & 4,010 & 94 & 107 \\
\hline 19 & $40 \%$ & 563.0 & 10 & 6 & Open & Open & 4 & 1,705 & 1,723 & 108 & 109 \\
\hline 20 & $40 \%$ & 564.0 & 10 & 6 & Open & Closed & 2 & 1,809 & 1,710 & 95 & 109 \\
\hline 21 & $40 \%$ & 563.1 & 10 & 6 & Closed & Open & 1 & 1,734 & 1,693 & 106 & 109 \\
\hline 22 & $60 \%$ & 563.1 & 18 & 15 & Closed & Open & 1 & 2,862 & 2,594 & 105 & 105 \\
\hline 23 & $60 \%$ & 563.1 & 18 & 14 & Open & Open & 2 & 2,889 & 2,576 & 107 & 110 \\
\hline 24 & $60 \%$ & 563.1 & 19 & 14 & Open & Closed & 4 & 2,963 & 2,575 & 95 & 109 \\
\hline 25 & $85 \%$ & 563.2 & 27 & 25 & Open & Closed & 4 & 4,195 & 3,945 & 96 & 105 \\
\hline 26 & $85 \%$ & 563.1 & 28 & 25 & Open & Open & 2 & 4,187 & 3,947 & 98 & 104 \\
\hline 27 & $85 \%$ & 563.1 & 28 & 26 & Closed & Open & 1 & 4,214 & 4,000 & 93 & 102 \\
\hline 28 & $85 \%$ & 563.3 & 29 & 29 & Closed & Closed & None & 4,195 & 4,110 & 93 & 93 \\
\hline 29 & $85 \%$ & 563.0 & & & Closed & Closed & None & 4,209 & 4,100 & 92 & 92 \\
\hline
\end{tabular}


MEC Water Resources, Inc.

Osage Project Supplemental Turbine Testing Report

III.E.2. Total Dissolved Gas - Comparison of Study Years

TDG observations during all study years followed a similar relationship with air: discharge ratio (Figure 59). However, the 2002 TDG observations were lower and more scattered than those observed during 2003 and 2005 at air: discharge ratios above 0.05 . This is likely attributed to instrumentation differences 2002 (Hydrolab TDG probe) while a Common Sensing TDG probe was utilized in 2003 and 2005.

TDG and dissolved oxygen relationships were similar for all study years (Figures 60 and 61). TDG typically exceeded the $110 \%$ criterion when the DO criterion $(5 \mathrm{mg} / \mathrm{L})$ was achieved in the discharge and DO increase was $4.5 \mathrm{mg} / \mathrm{L}$. 


\section{CONCLUSIONS}

Significant improvements in discharge DO concentrations were achieved since 2002 and are documented in this study. Various operating scenarios and configurations provided valuable data to help optimize operating conditions in terms of DO concentrations downstream of the Osage Project. The following summary provides the key study findings.

IV.A. General Findings

Several fundamental relationships were observed in all study year datasets when comparing tailwater DO concentration, TDG, airflow, oxygen transfer efficiency, discharge rates, and tailrace elevation. These relationships can be summarized as follows:

- Tailwater DO concentrations generally decreased with increasing turbine discharge rate and tailrace elevation.

- Airflow through the study turbines generally decreased with increasing tailrace elevation.

- Oxygen transfer efficiency increased with increasing discharge rate and increasing tailrace elevation.

- The relationship between aeration efficiency (which accounts for water temperature) and air:discharge ratio was similar for all study year datasets, providing further validation that aeration is a function of the air:discharge ratio.

- The relationship between TDG saturation and air:discharge ratio is similar to aeration efficiency. TDG saturation is also directly related to DO saturation.

- The TDG water quality criterion (110\% saturation) was typically exceeded when the DO criterion ( $5 \mathrm{mg} / \mathrm{L}$ minimum) was exceeded.

The study data also allow comparison of various turbine designs and venting configurations. These comparisons provide valuable insight into potential Project modifications for improvement of downstream water quality. The following conclusions are presented based on the study data:

\section{IV.B. Main Generator 6}

- Use of draft tubes and main vents together resulted in consistently higher air flows than use of draft tube vent or new main vents alone.

- The four new main vents were more effective than the draft tube vent at lower gate settings through the range of tailrace elevations.

- The four new main vents in 2005 had similar performance to the two original main vents in the 2002 and 2003 when tailrace elevations were 560 or greater.

- The draft tube vent provided greater airflow than the main vents at the higher gate settings through the range of tailrace elevations. 
- The combination of the new main vents and the draft tube vents produced the greatest amount of total airflow for all MG6 configurations of gate settings and tailrace elevations

- The relationship between DO and discharge at high tailrace elevations were opposite for the new main vents and the draft tube vent only. The new main vent configuration resulted in higher DO levels at the lower gate settings, while the draft tube vent produced higher DO levels as discharge increased.

- $\quad$ The draft tube vent and the four new main vents installed at MG6 in 2005 increased airflow compared to 2002 and 2003 studies of original main and manual auxiliary vents. MG6 discharge DO concentrations were on average 1.2 to 2.4 mg/L higher in 2005 than in 2002 at moderate to high tailrace evelations.

- With the draft tube and main vents open, the MG6 discharge met or exceeded the dissolved oxygen water quality criterion $(5 \mathrm{mg} / \mathrm{L})$ until a relatively high tailrace elevation (560') was reached.

- Discharge DO was enhanced by modifications made to MG6 from 2002 to 2005 as summarized in Table 4.

Table 4: Main Generator 6 Discharge Dissolved Oxygen Enhancement from 2002 to 2005

\begin{tabular}{|c|c|c|c|c|c|c|c|c|c|}
\cline { 2 - 10 } \multicolumn{1}{c|}{} & \multicolumn{9}{c|}{ Discharge Dissolved Oxygen (mg/L) } \\
\cline { 2 - 10 } \multicolumn{1}{c|}{} & \multicolumn{4}{c|}{2002} & \multicolumn{3}{c|}{2005} & \multicolumn{3}{c|}{ Difference (2005-2002) } \\
\hline \multirow{2}{c}{$\begin{array}{c}\text { Tailrace Elevation } \\
\text { (ft. MSL) }\end{array}$} & \multicolumn{3}{c|}{ Gate Setting } & \multicolumn{3}{c|}{ Gate Setting } & \multicolumn{3}{c|}{ Gate Setting } \\
\cline { 2 - 11 } & $40 \%$ & $60 \%$ & $80 \% \& 90 \%$ & $40 \%$ & $60 \%$ & $85 \%$ & $40 \%$ & $60 \%$ & $85 \%$ \\
\hline 556 & 3.90 & 3.11 & 2.04 & 5.59 & 5.73 & 5.05 & 1.69 & 2.62 & 3.02 \\
\hline 560 & 3.01 & 3.05 & 2.00 & 4.95 & 5.17 & 3.70 & 1.94 & 2.12 & 1.71 \\
\hline 563 & 3.61 & 3.28 & 2.60 & 4.50 & 4.84 & 3.84 & 0.89 & 1.56 & 1.25 \\
\hline
\end{tabular}




\section{IV.C. Main Generator 3}

- Removal of check valves from the MG3 vents in 2005 had no significant impacts on airflow through the units.

- Airflows through two main vents were similar to those measured in four main vents indicating that there is little gain in airflow with the use of four main vents compared to two.

- Airflows were reduced with one main vent at low gate settings and moderate tailrace elevation, which indicates promise in controlling airflow low tailrace elevations and gate settings. This control measure may be useful in reducing TDG levels during vented, baseflow conditions.

- The fully vented $\mathrm{MG}_{3}$ discharge during 2005 met the $5.0 \mathrm{mg} / \mathrm{L}$ dissolved oxygen criterion until high gate setting (85\%) and moderate tailrace elevation (556') was reached.

- MG3 discharge DO concentrations increased an average of 1.2 to $1.6 \mathrm{mg} / \mathrm{L}$ in 2005 compared to 2002 at moderate to high tailrace elevations (Table 5). The majority of this increase was observed after the 2002 study year and is attributed to the removal of the nosecone bottom plate.

Table 5: Main Generator 3 Discharge Dissolved Oxygen Enhancement from 2002 to 2005

\begin{tabular}{|c|c|c|c|c|c|c|c|c|c|}
\hline & \multirow{2}{*}{\multicolumn{9}{|c|}{ Discharge Dissolved Oxygen (mg/L) }} \\
\hline & & & & & & & & & \\
\hline & \multicolumn{3}{|c|}{2002} & \multicolumn{3}{|c|}{2005} & \multicolumn{3}{|c|}{ Difference (2005-2002) } \\
\hline \multirow{2}{*}{$\begin{array}{c}\text { Tailrace Elevation } \\
\text { (ft. MSL) }\end{array}$} & \multicolumn{3}{|c|}{ Gate Setting } & \multicolumn{3}{|c|}{ Gate Setting } & \multicolumn{3}{|c|}{ Gate Setting } \\
\hline & $40 \%$ & $60 \%$ & $80 \% \& 90 \%$ & $40 \%$ & $60 \%$ & $85 \%$ & $40 \%$ & $60 \%$ & $85 \%$ \\
\hline 556 & 5.02 & 4.10 & 3.12 & 5.95 & 5.50 & 4.69 & 0.93 & 1.40 & 1.57 \\
\hline 560 & 3.63 & 3.21 & 2.60 & 4.66 & 4.82 & 4.82 & 1.03 & 1.61 & 2.22 \\
\hline 563 & 3.49 & 3.39 & 2.92 & 4.20 & 4.57 & 4.47 & 0.71 & 1.18 & 1.56 \\
\hline
\end{tabular}




\section{IV.D. Comparison of Main Generators 3 and 6}

- MG6 with draft tube and main vents produced greater airflow and tailrace DO than $M G_{3}$ at high gate settings ( $85 \%$ ) and moderate to high tailrace elevations (560 to 563 ).

- $M G_{3}$ discharge $\mathrm{DO}$ at high tailrace and high gate settings was significantly greater than MG6 discharge DO at similar configurations (Table 6)

Table 6: Main Generators 3 and 6 Discharge Dissolved Oxygen Comparison - 2005

\begin{tabular}{|c|c|c|c|c|c|c|c|c|c|}
\cline { 2 - 10 } \multicolumn{1}{c|}{} & \multicolumn{4}{c|}{ MG Discharge Dissolved Oxygen (mg/L) } \\
\cline { 2 - 10 } \multicolumn{1}{c|}{} & \multicolumn{4}{c|}{ MG $3.45 \%$} & \multicolumn{3}{c|}{ MG6 } & \multicolumn{3}{c|}{ Difference } \\
\hline \multirow{2}{*}{$\begin{array}{c}\text { Tailrace Elevation } \\
\text { (ft. MSL) }\end{array}$} & \multicolumn{3}{c|}{ Gate Setting Setting } \\
\cline { 2 - 10 } & $40 \%$ & $60 \%$ & $85 \%$ & $40 \%$ & $60 \%$ & $85 \%$ & $40 \%$ & $60 \%$ & $85 \%$ \\
\hline 556 & 5.95 & 5.5 & 4.69 & 5.59 & 5.73 & 5.05 & 0.36 & -0.23 & -0.36 \\
\hline 560 & 4.66 & 4.82 & 4.82 & 4.95 & 5.17 & 3.70 & -0.29 & -0.35 & 1.12 \\
\hline 563 & 4.2 & 4.57 & 4.47 & 4.50 & 4.84 & 3.84 & -0.30 & -0.27 & 0.63 \\
\hline
\end{tabular}

*** Negative values indicated that MG6 DO was greater than MG3. 


\section{APPENDIX 1}


Figure 1: Modifications made to Main Generator 62003 and 2005

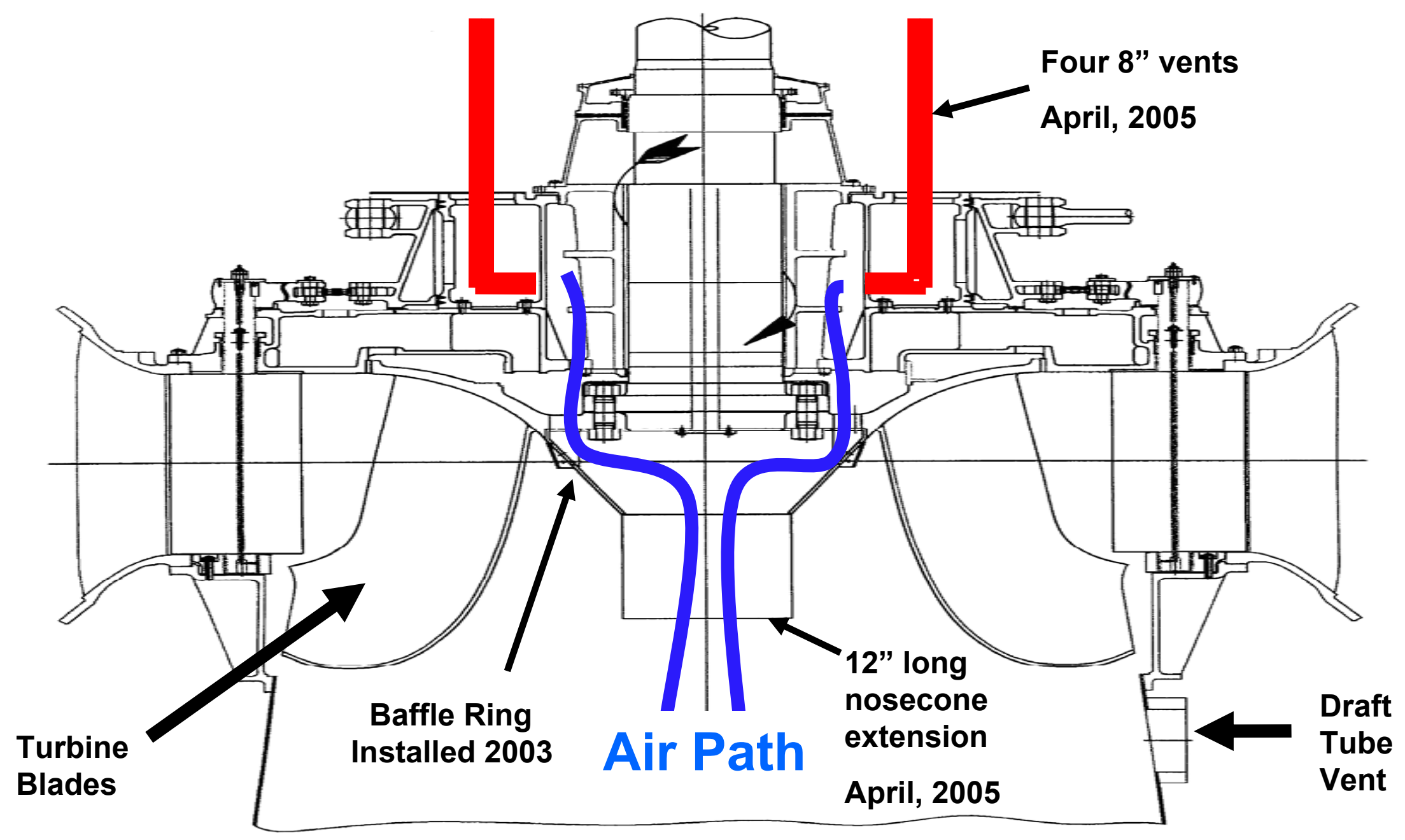


Figure 2

Diagram of Discrete Sampling Device

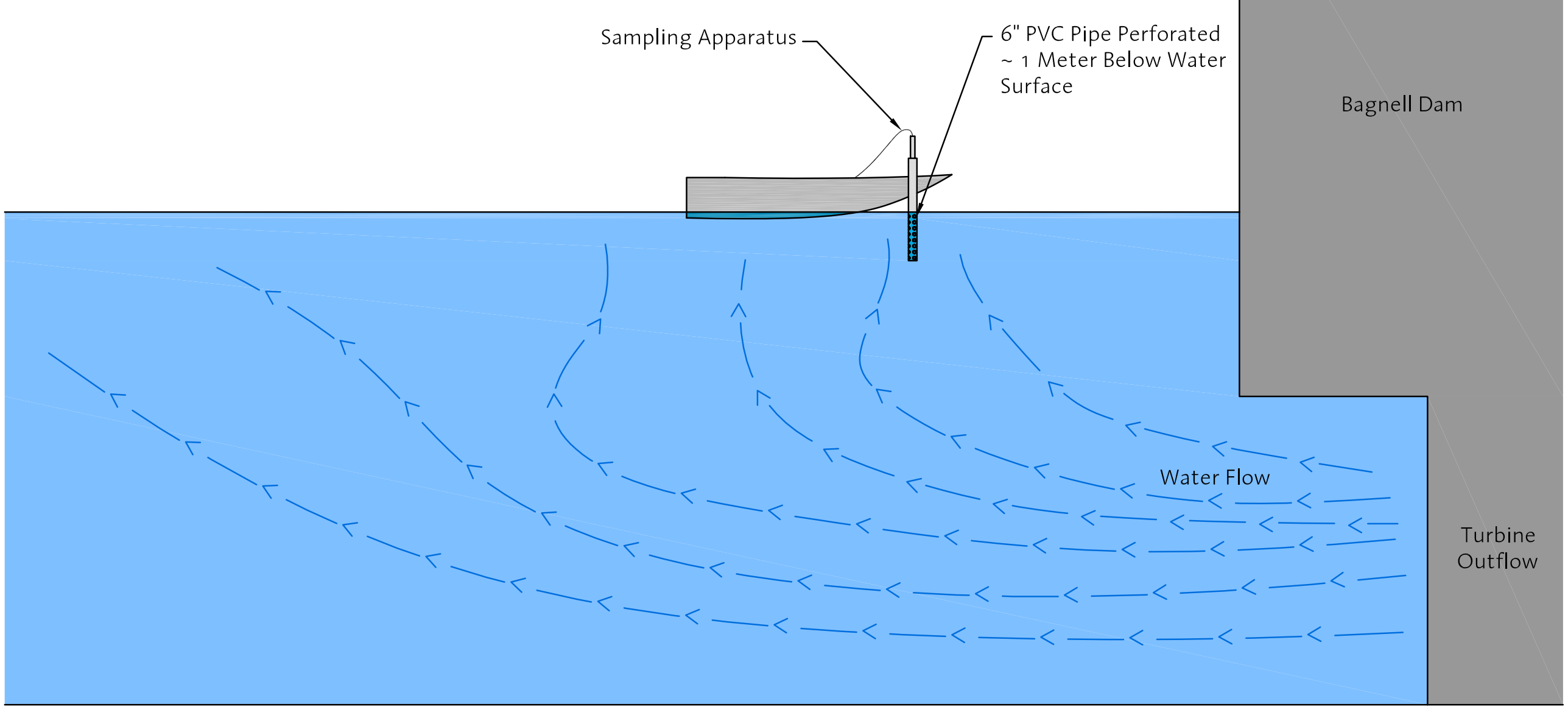


Figure 3

Photograph of Discrete Sampling Device

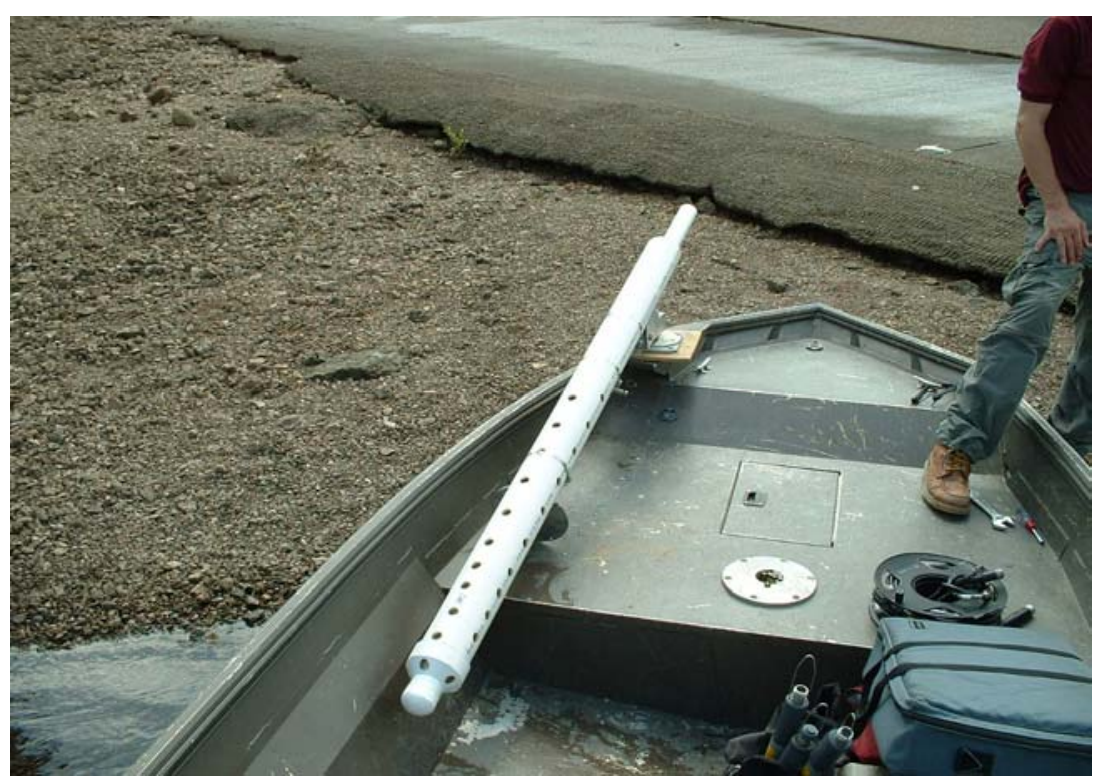

Figure 4

Photograph of Discrete Sampling Device - Deployed

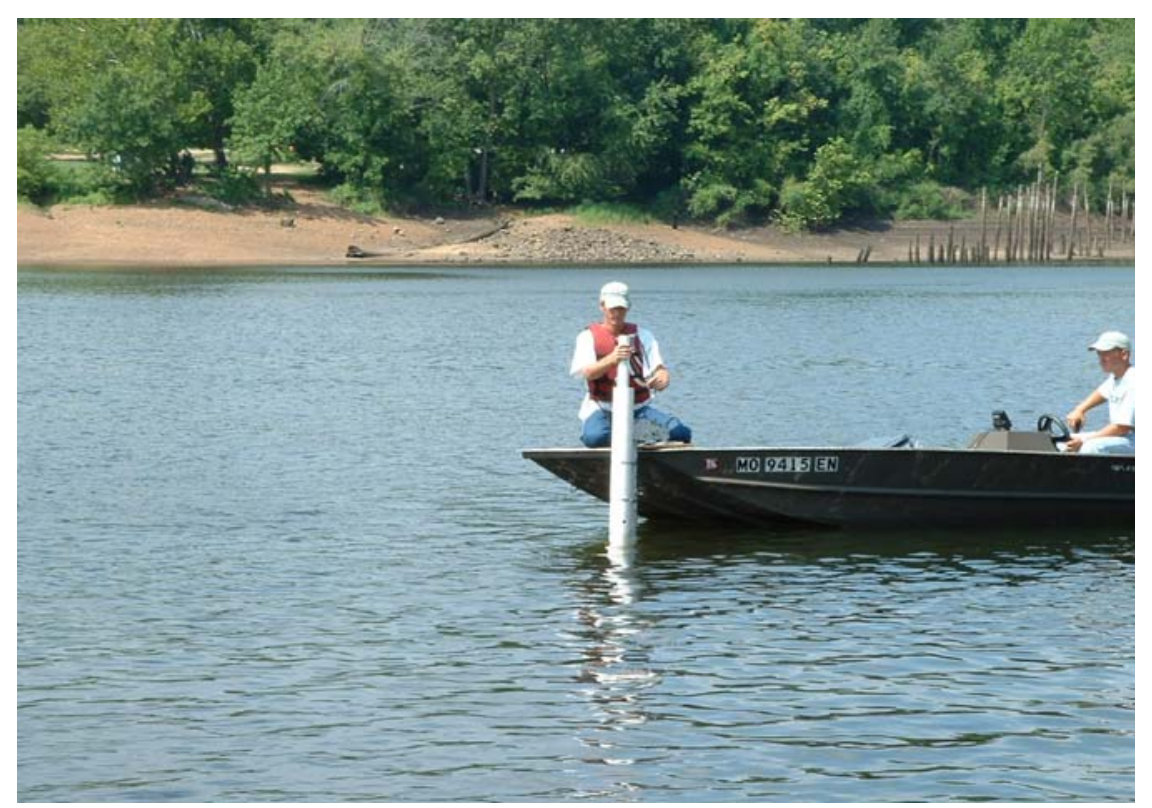




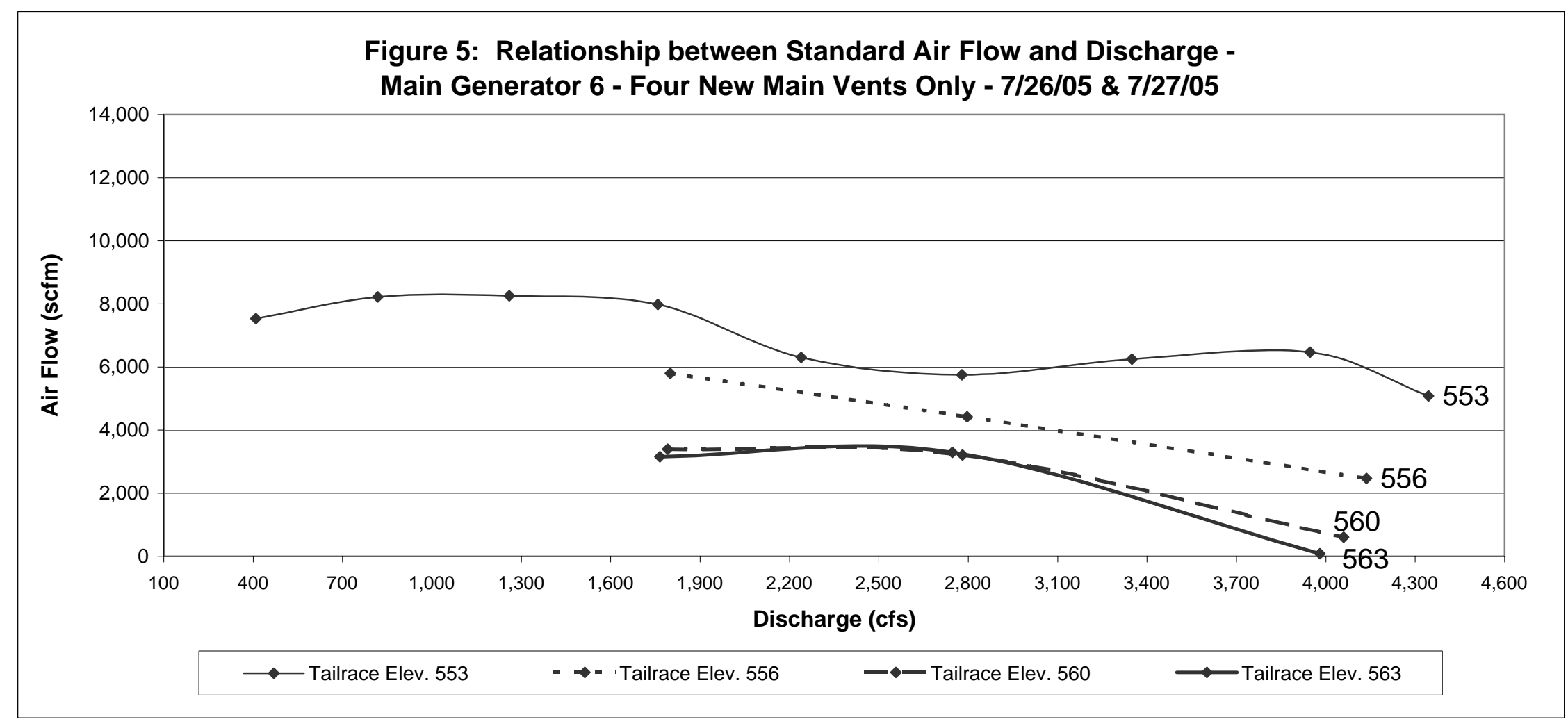




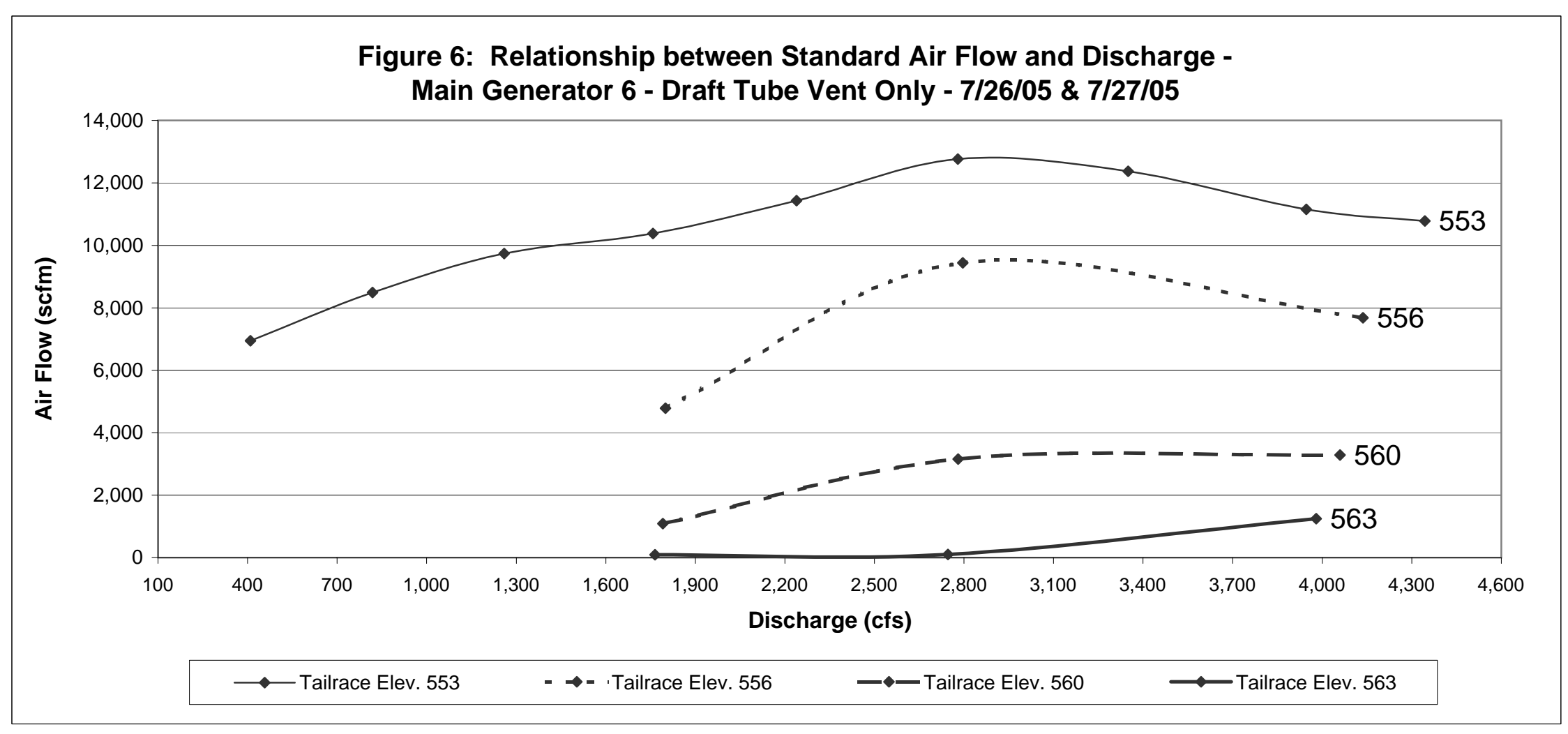




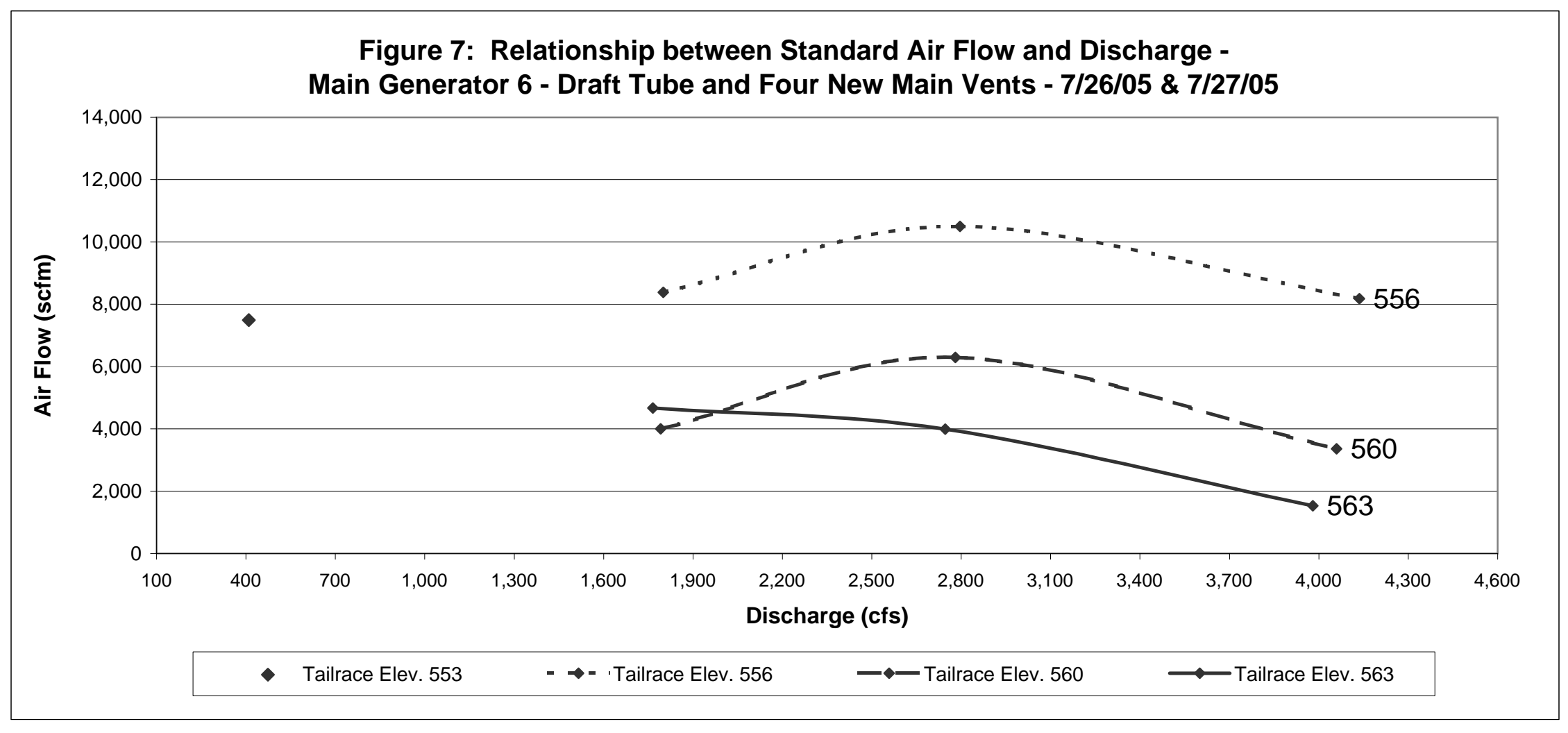




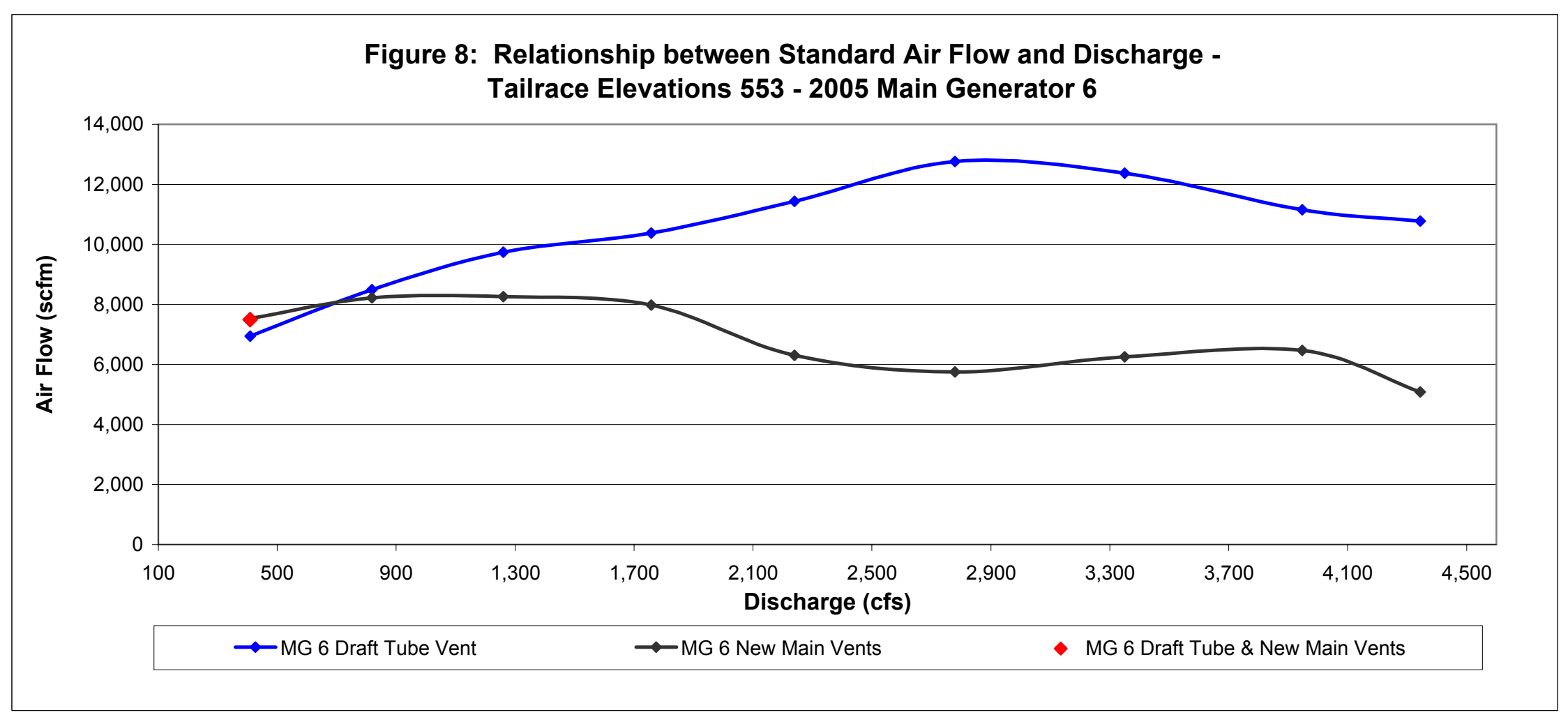




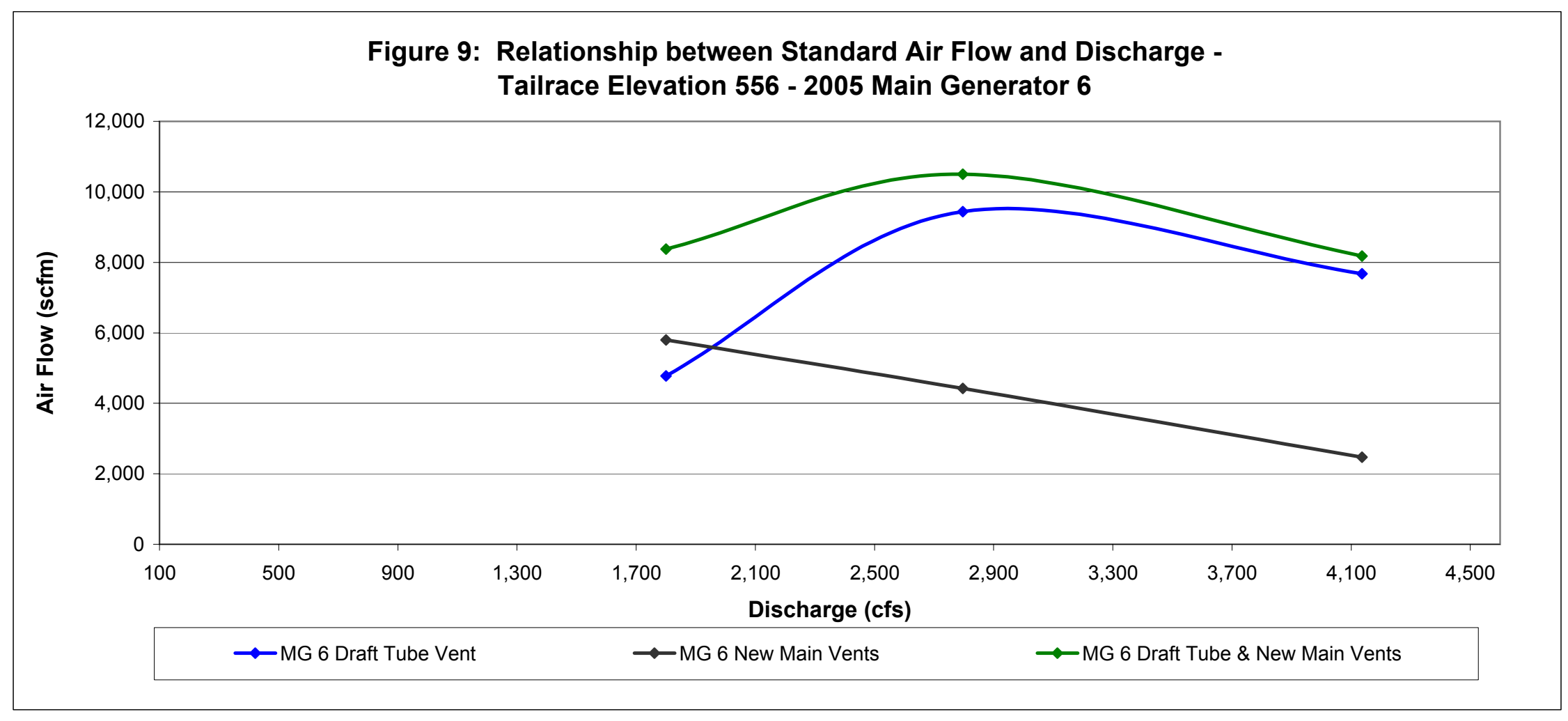




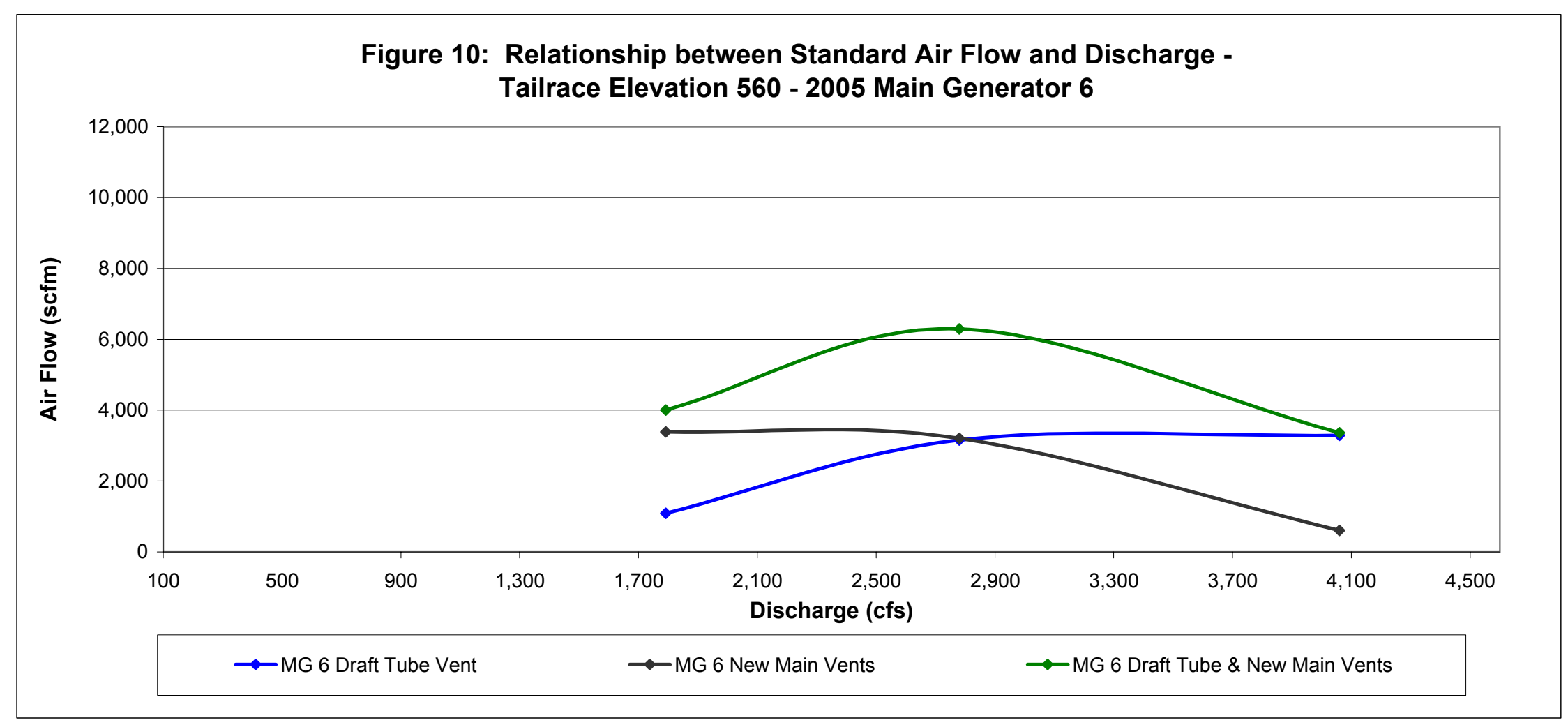




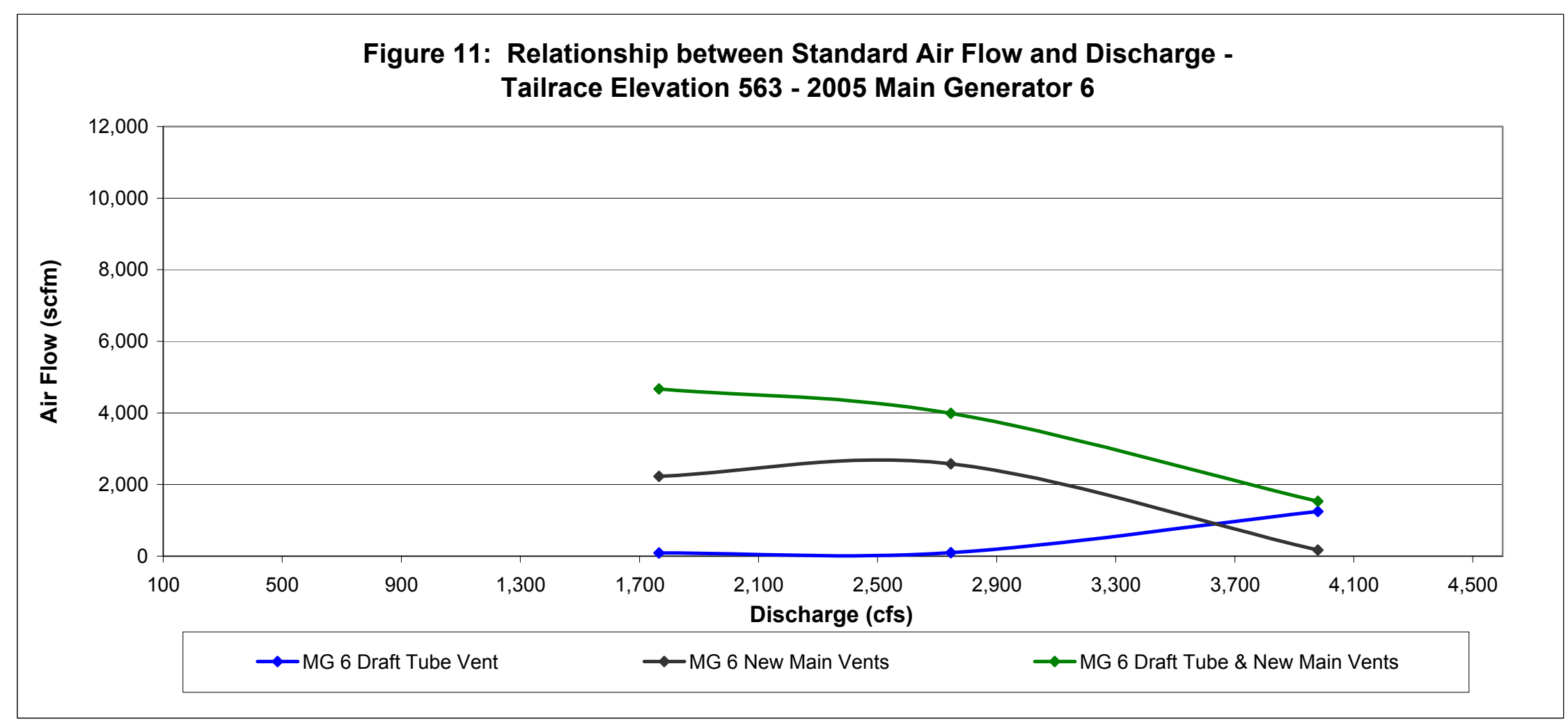




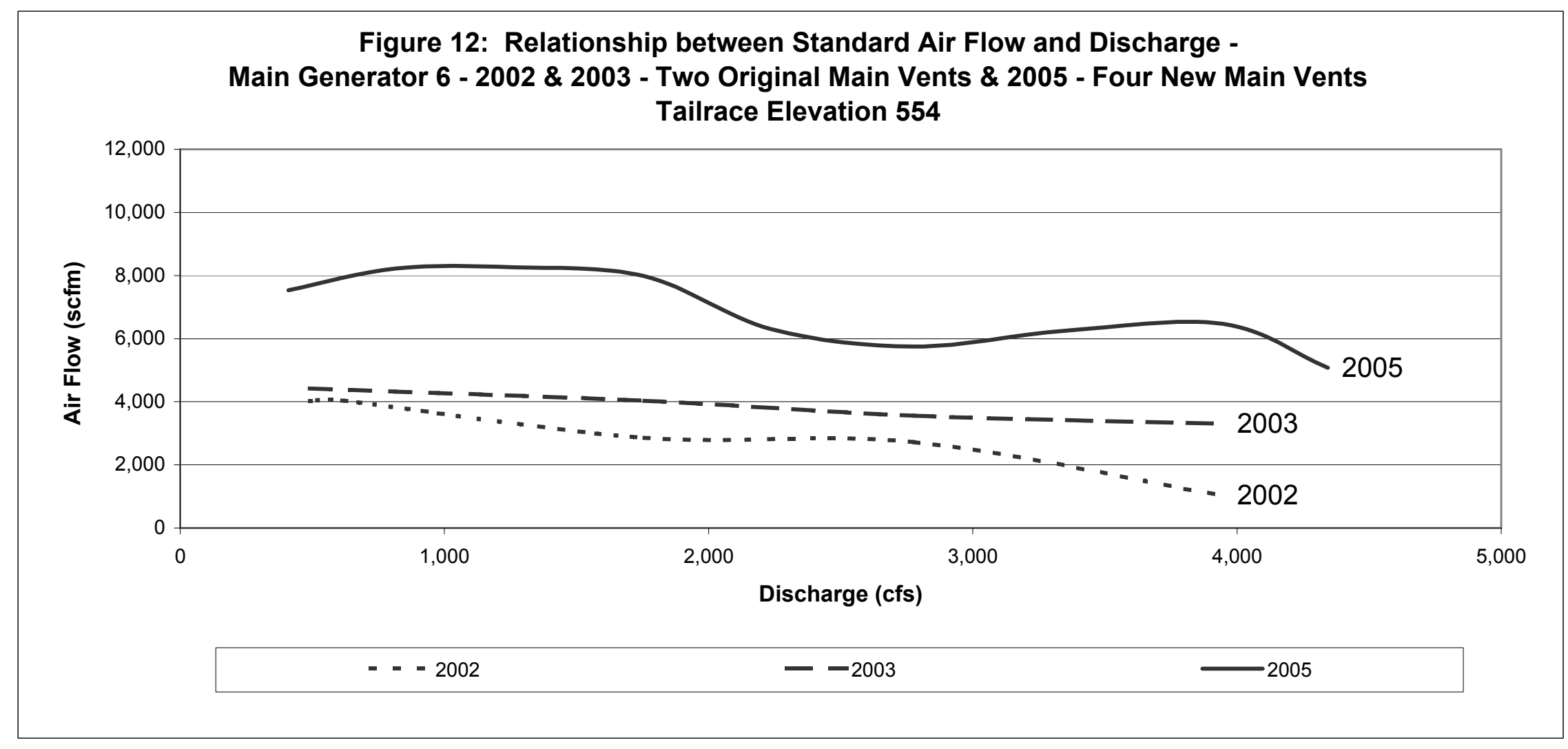




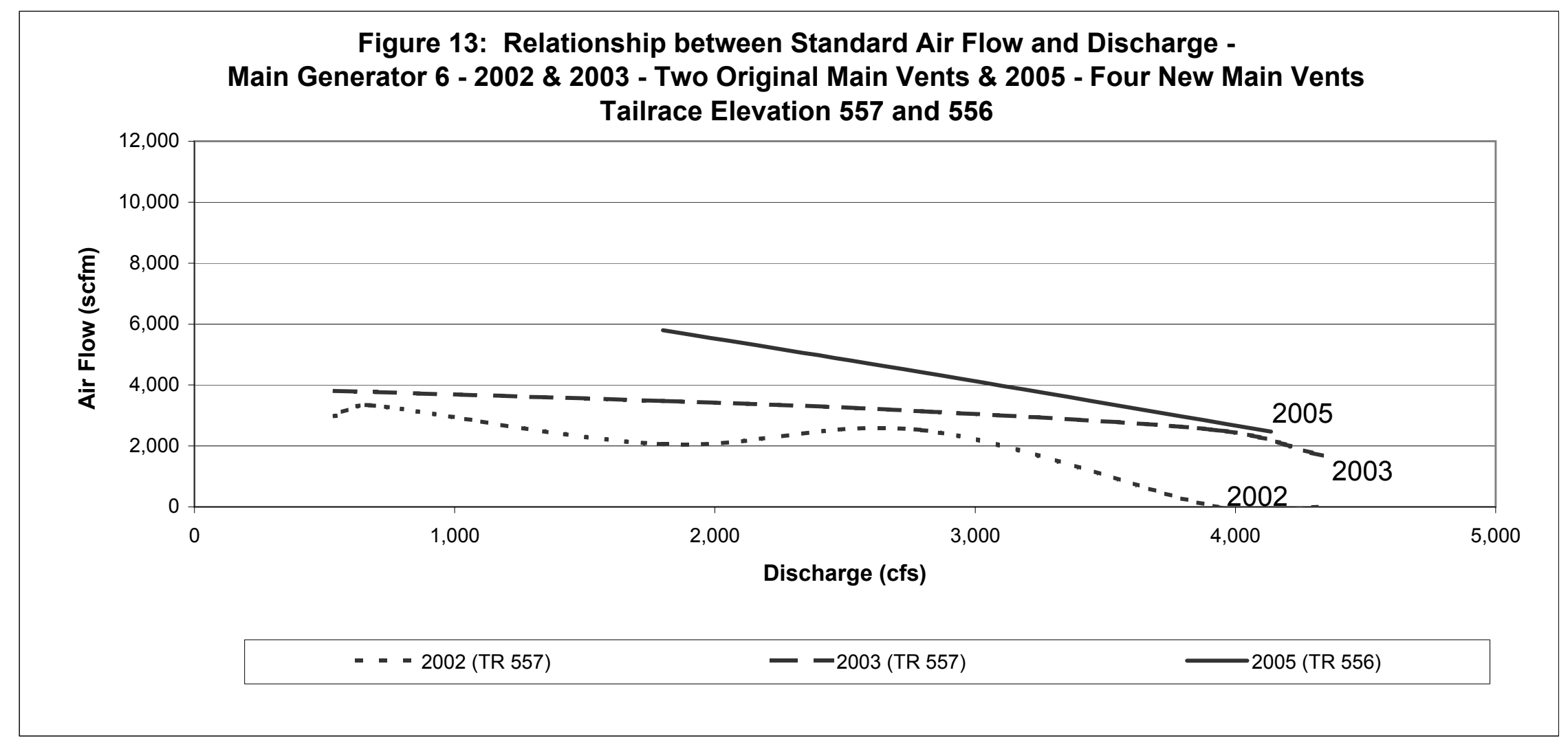




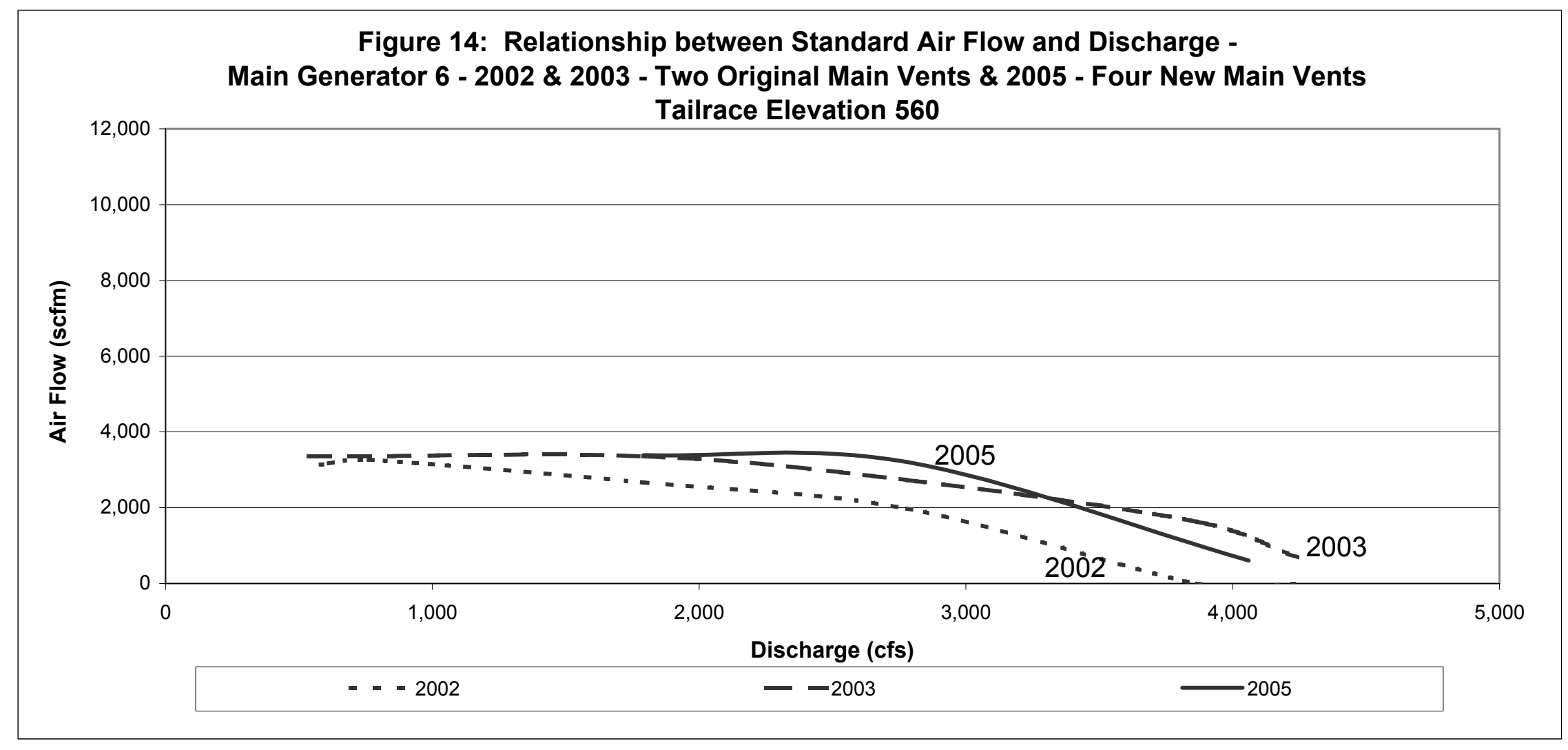




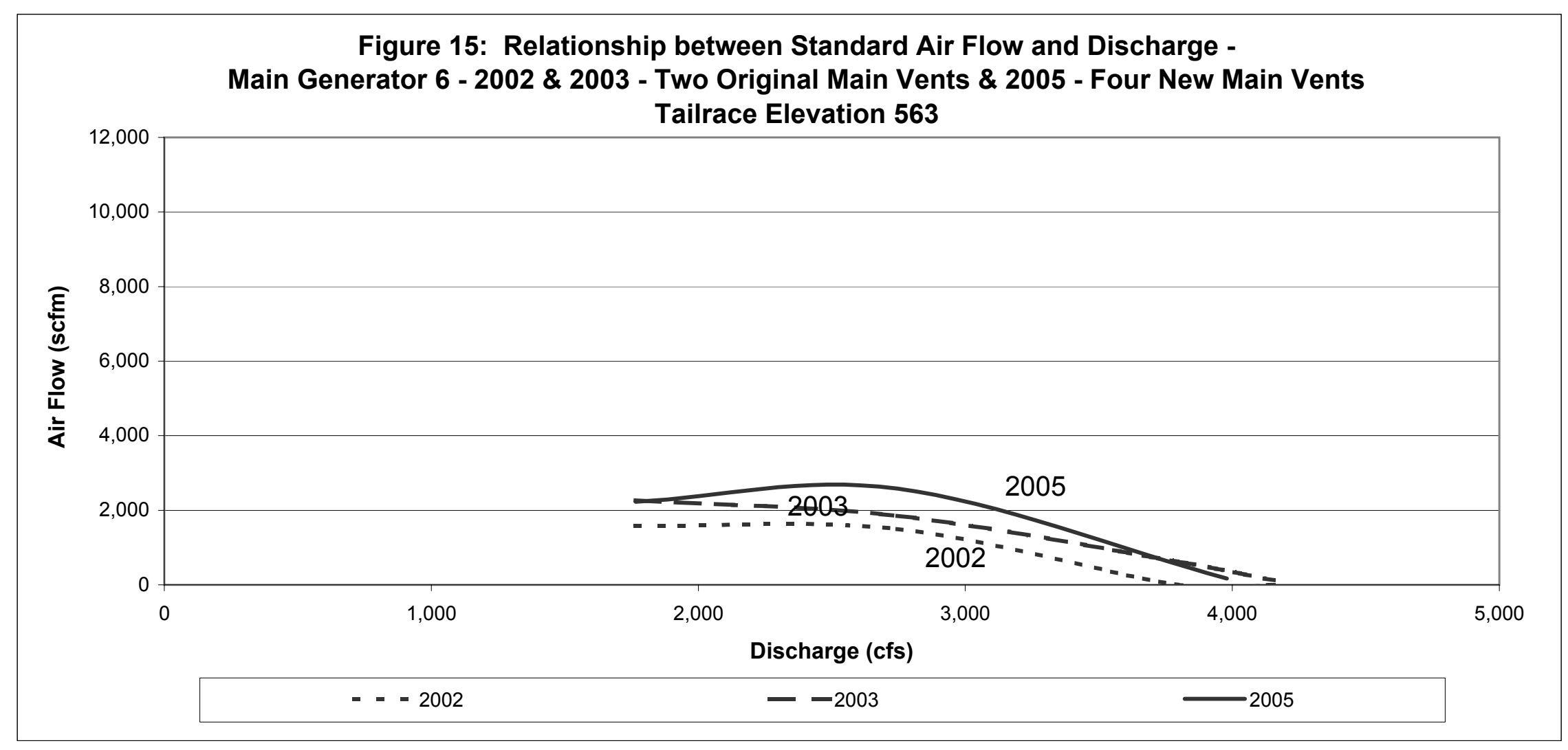




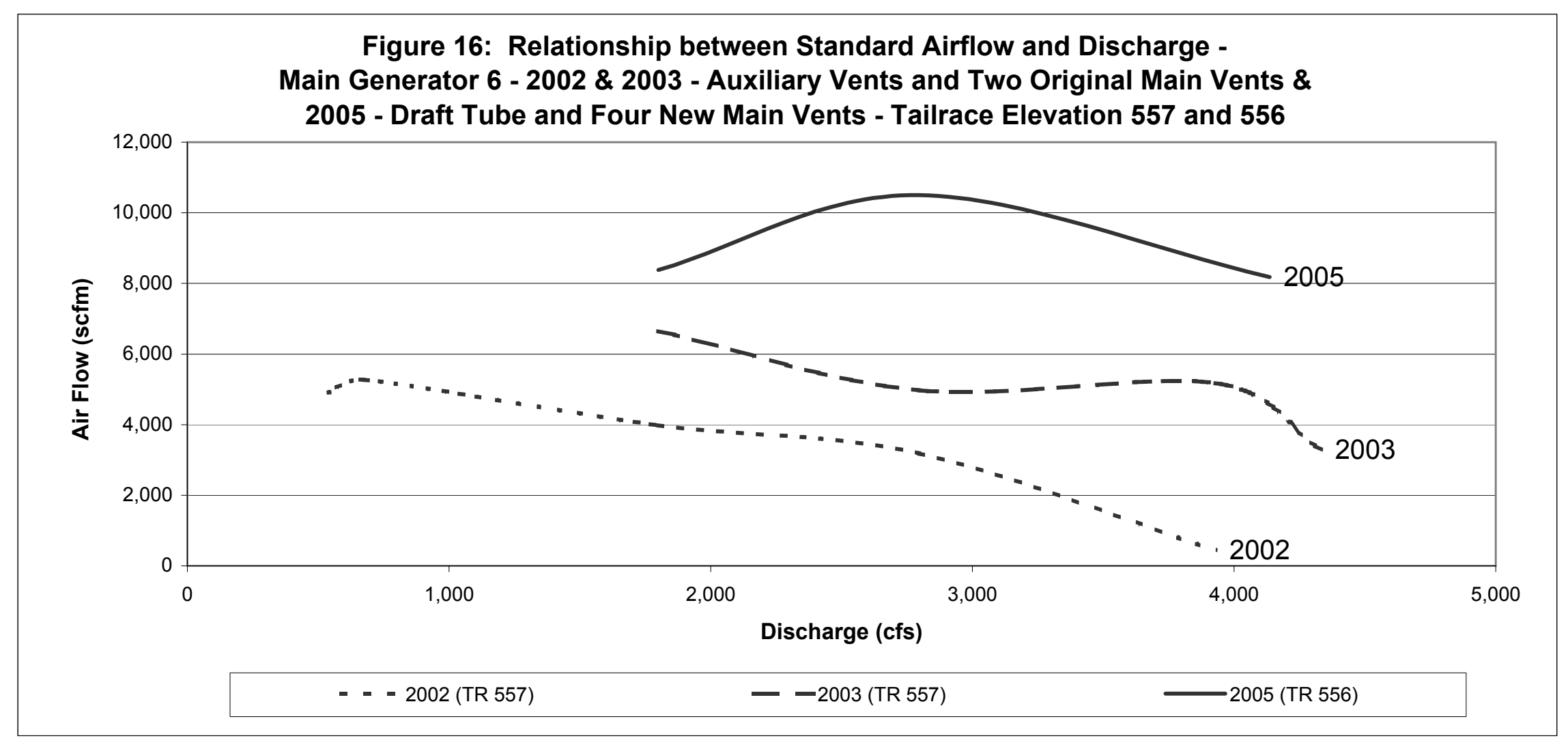




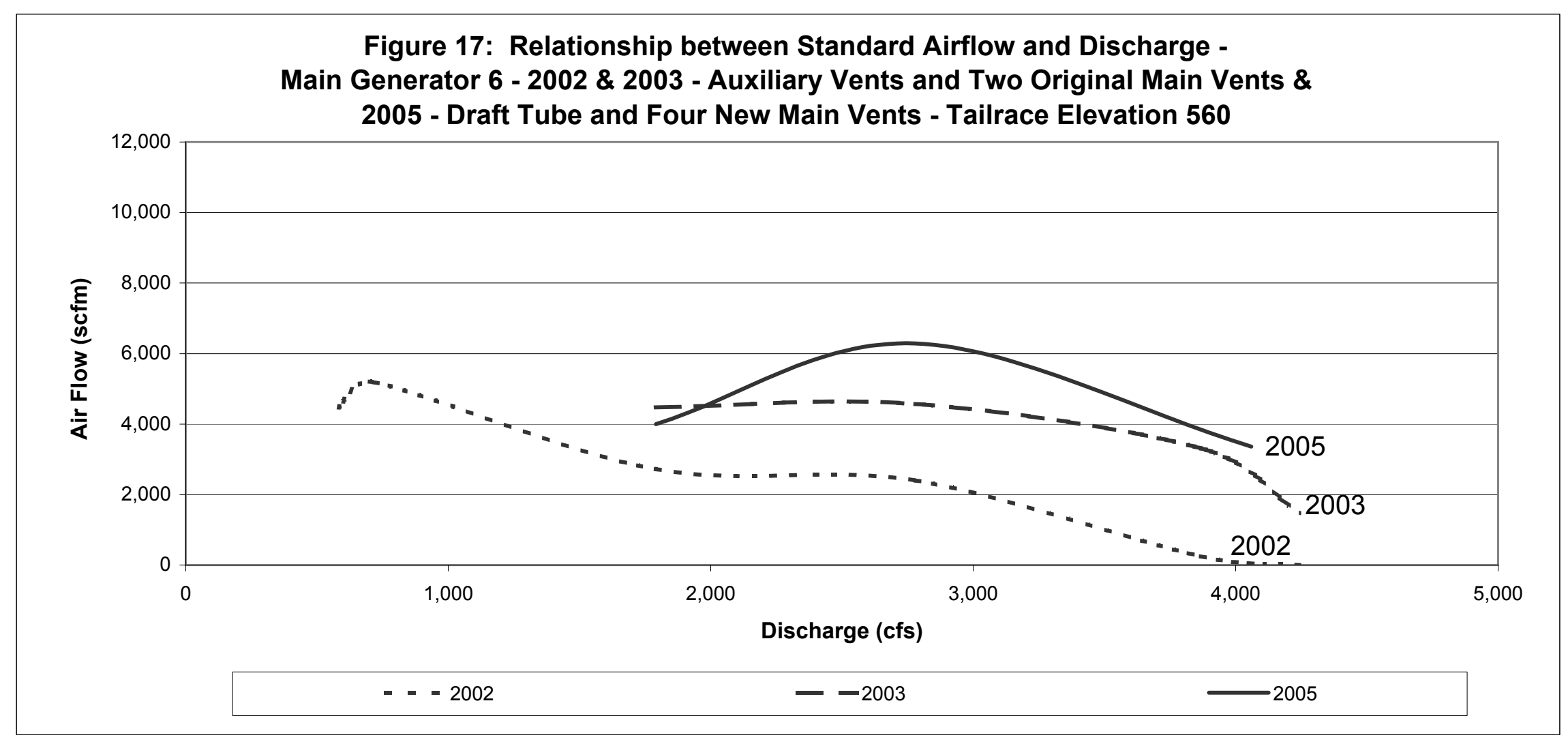




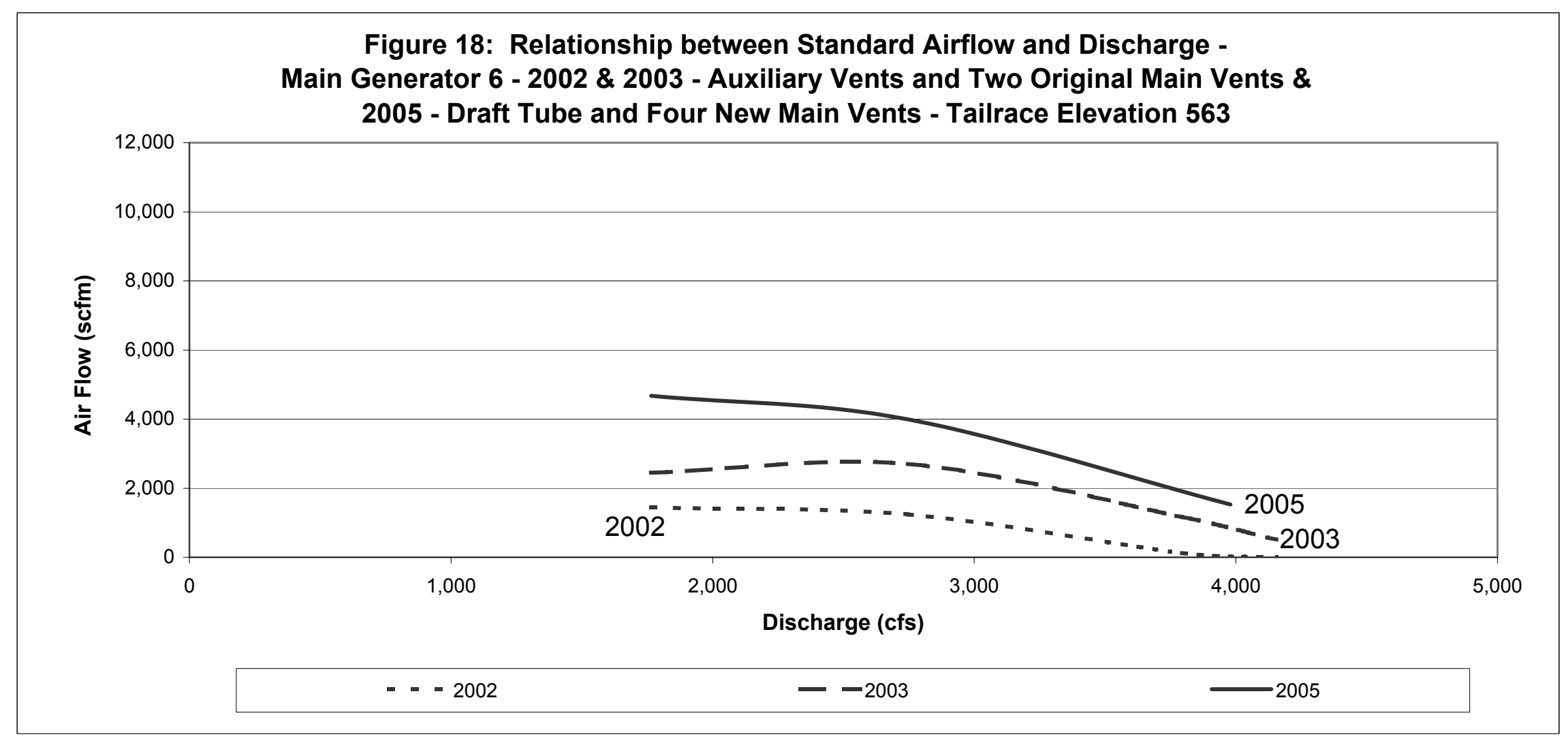




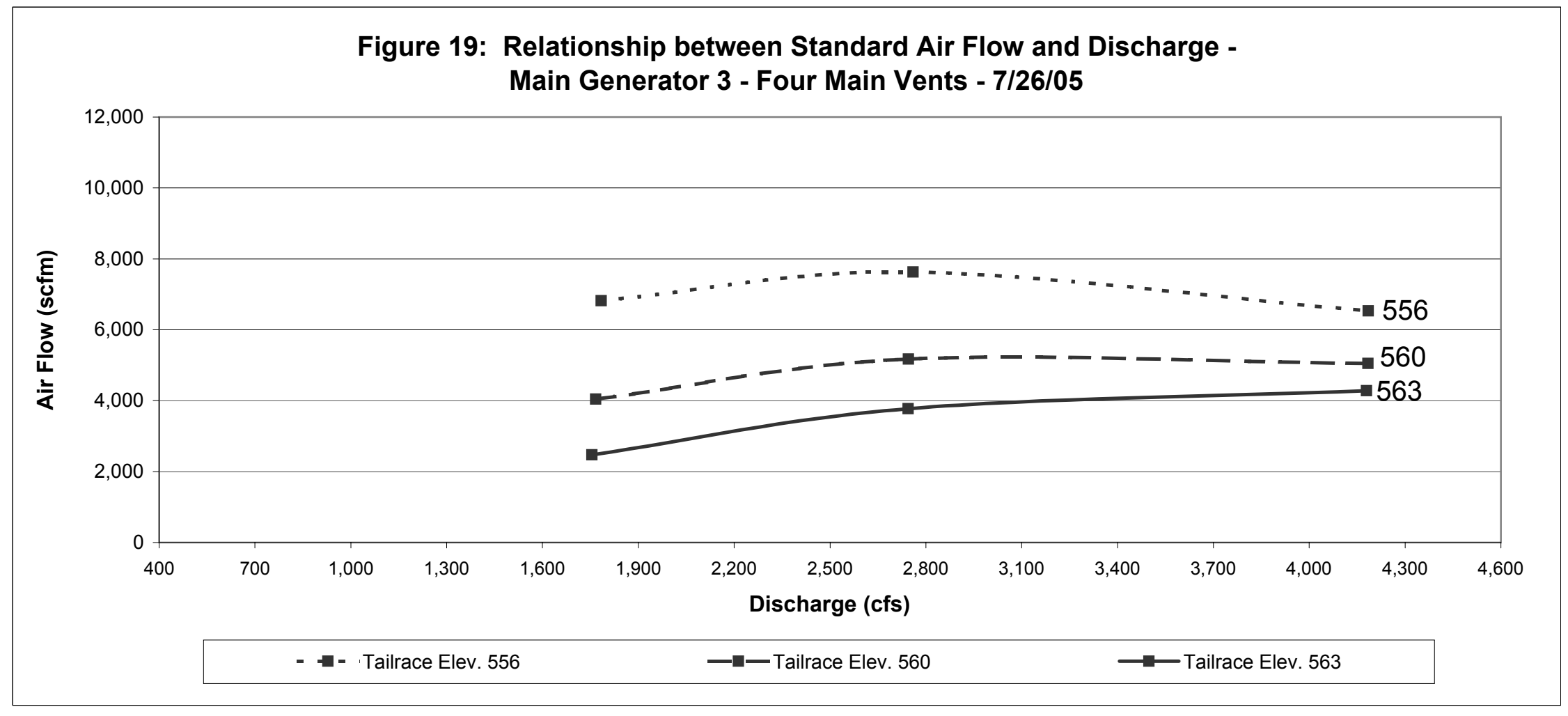




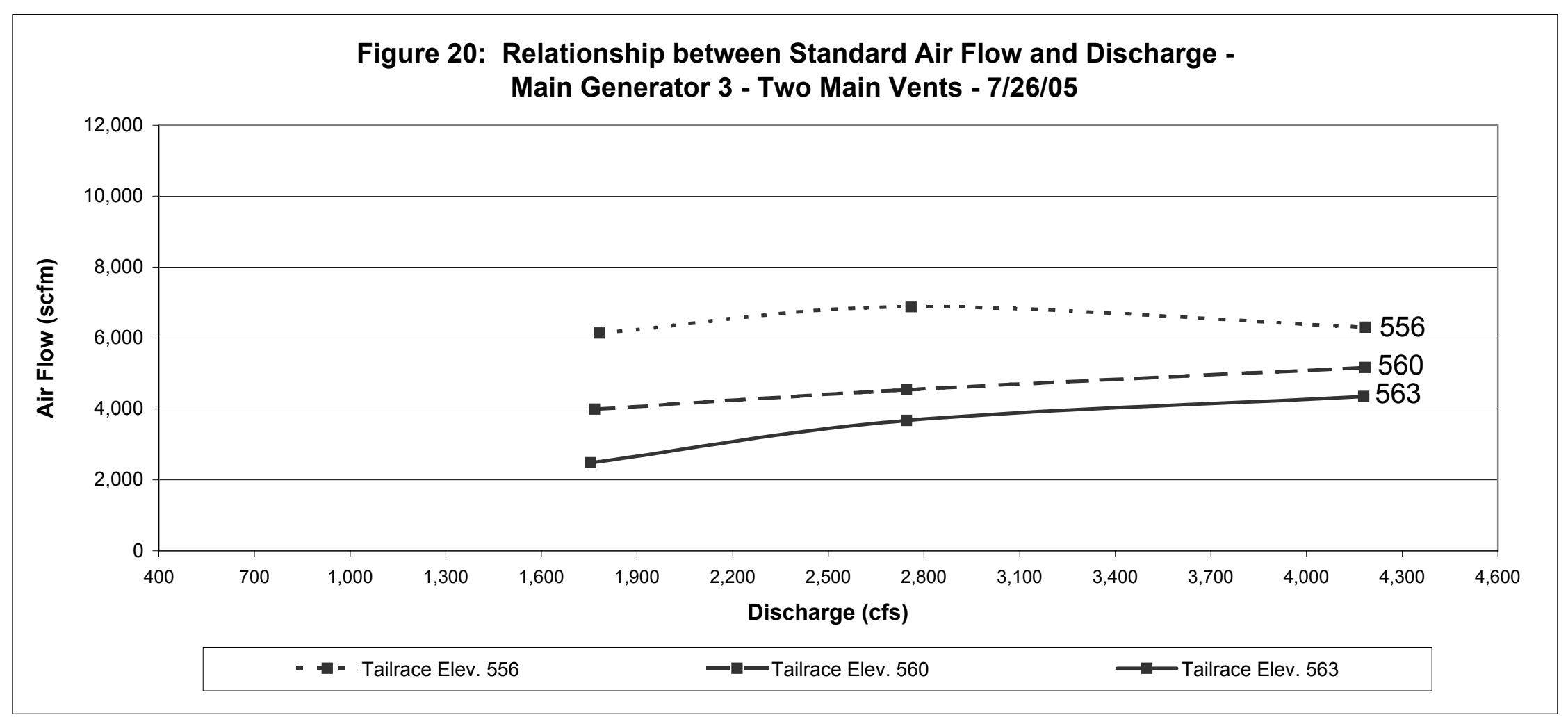




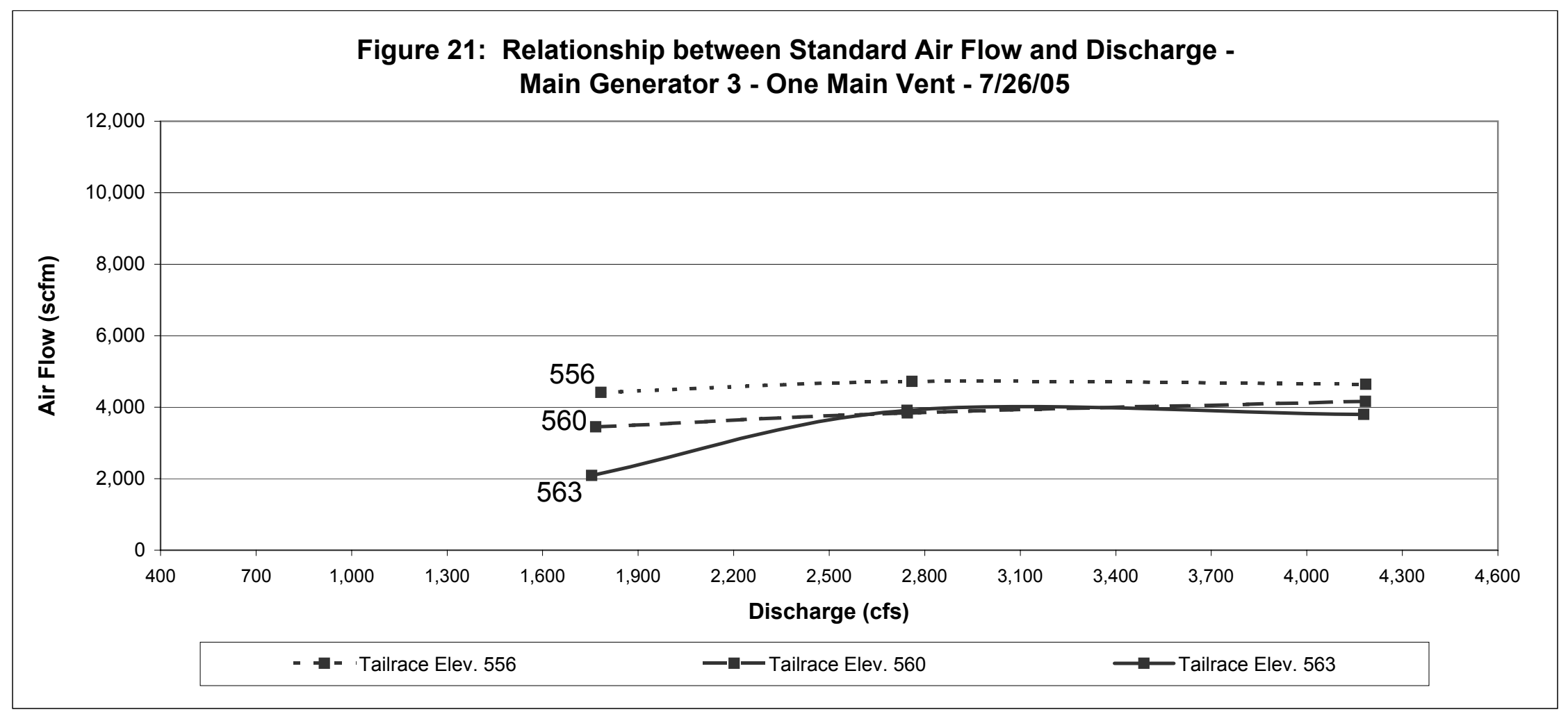




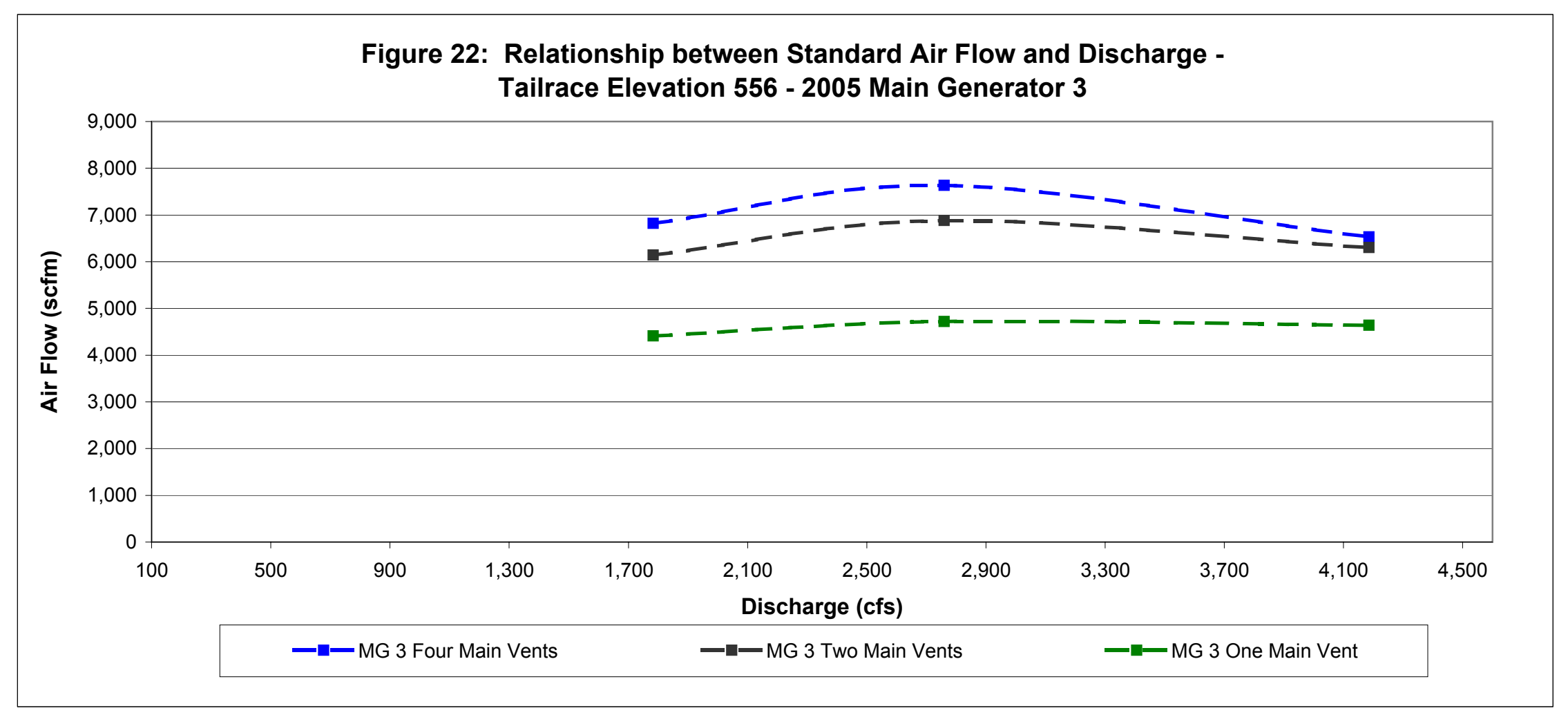




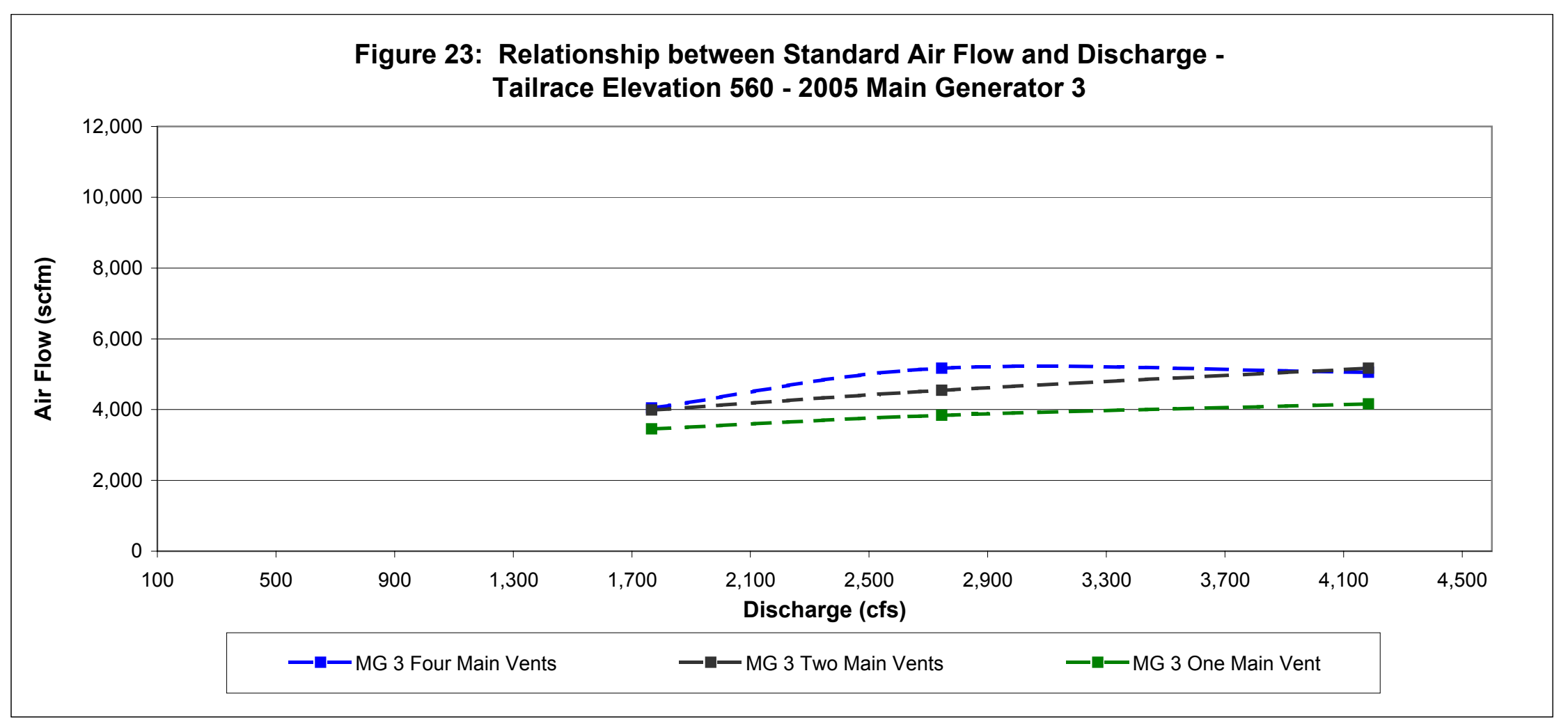




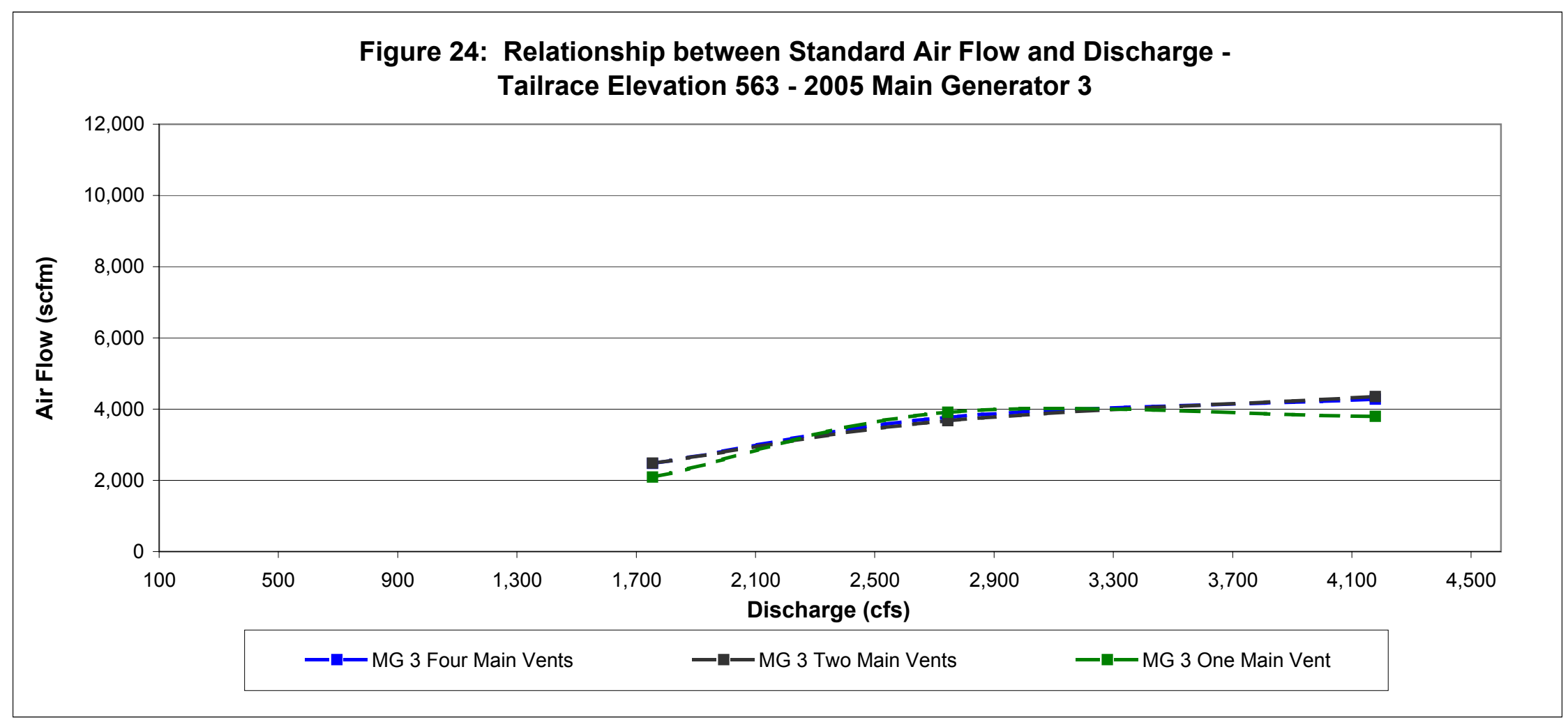




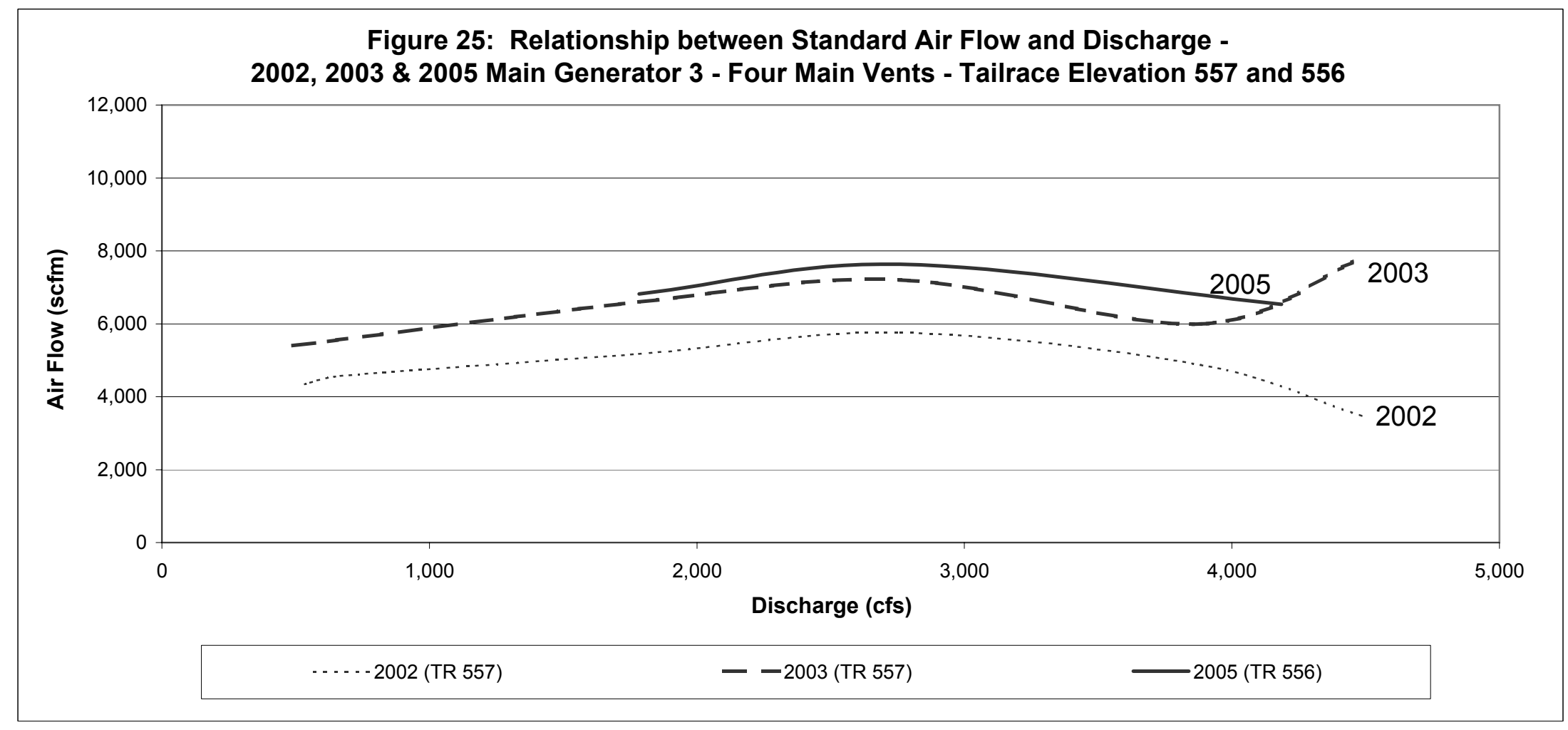




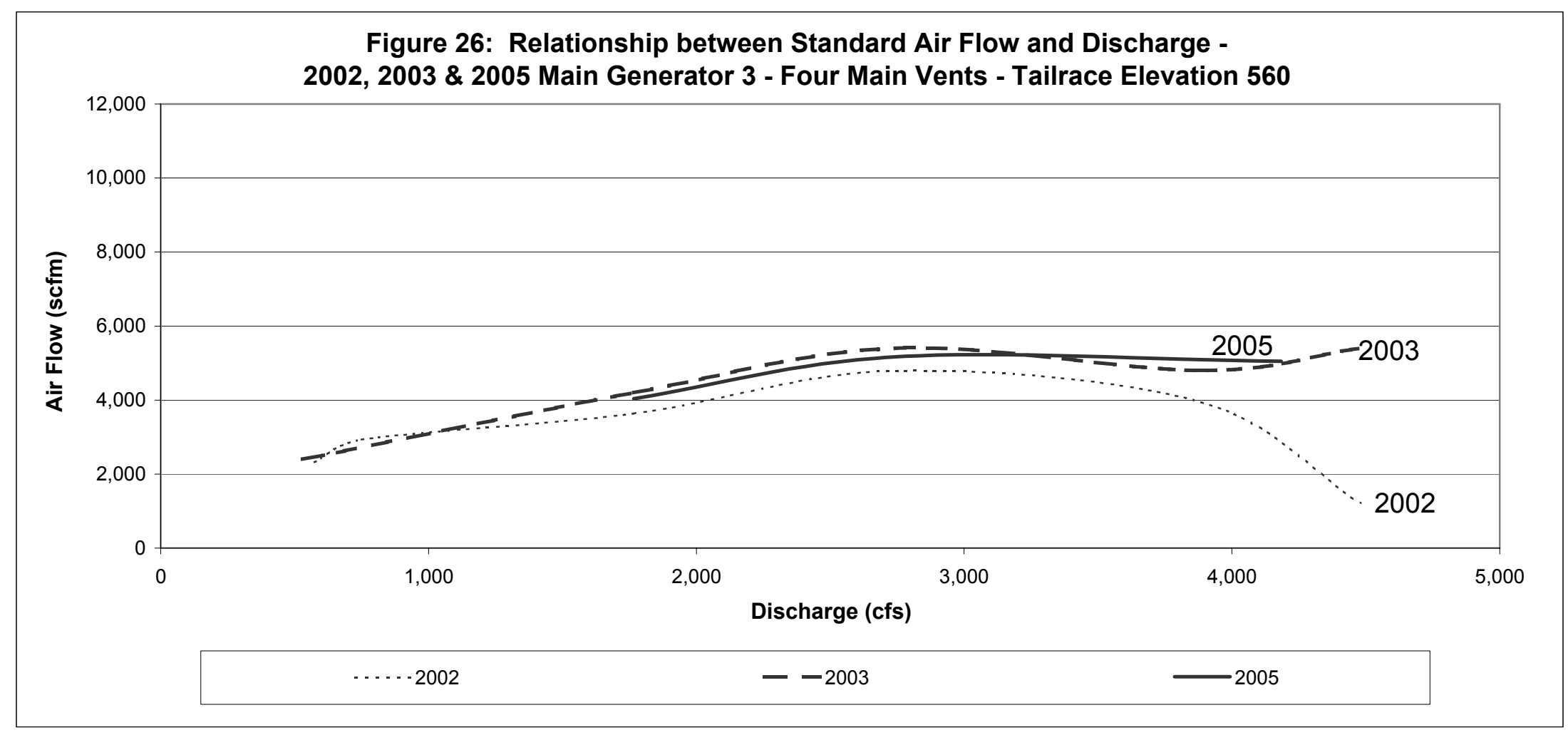




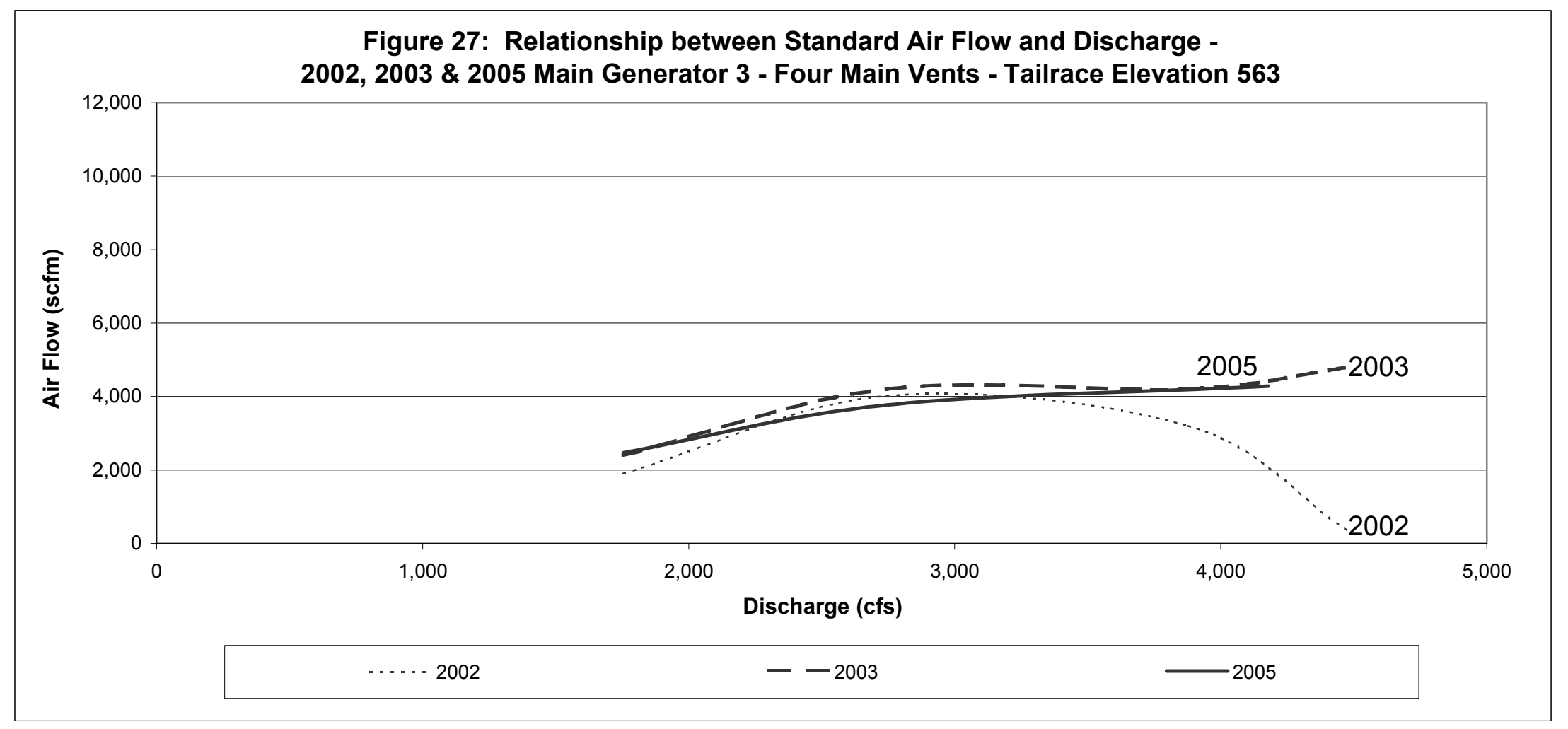




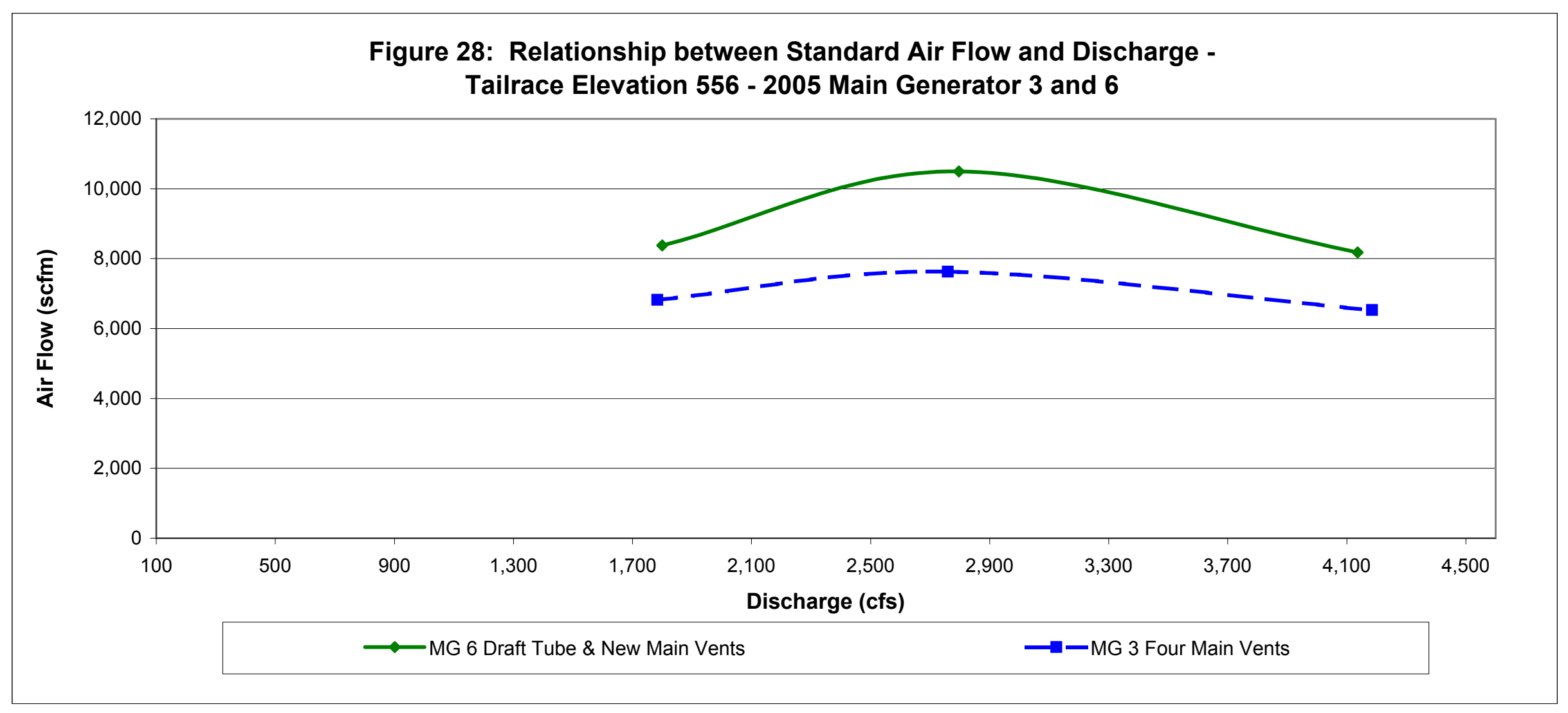




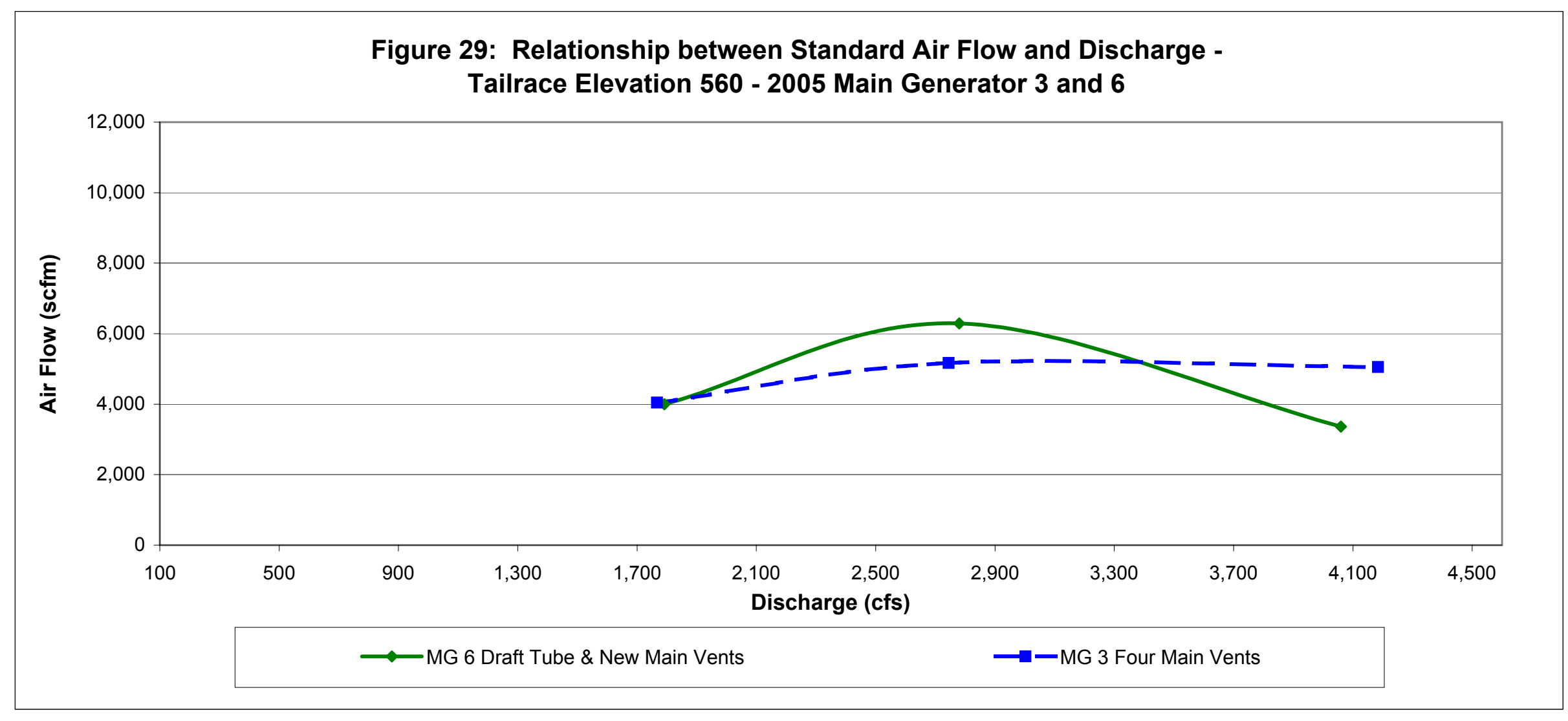




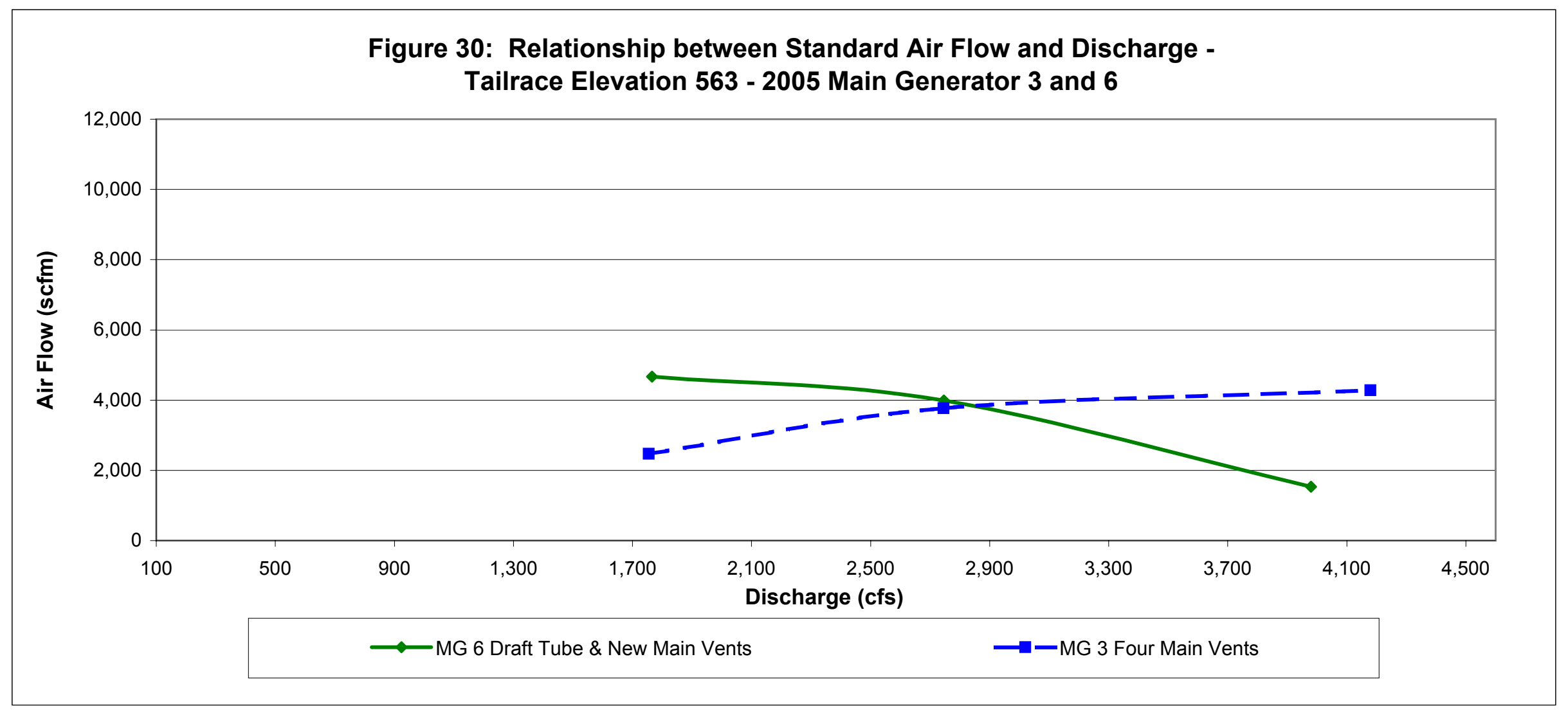




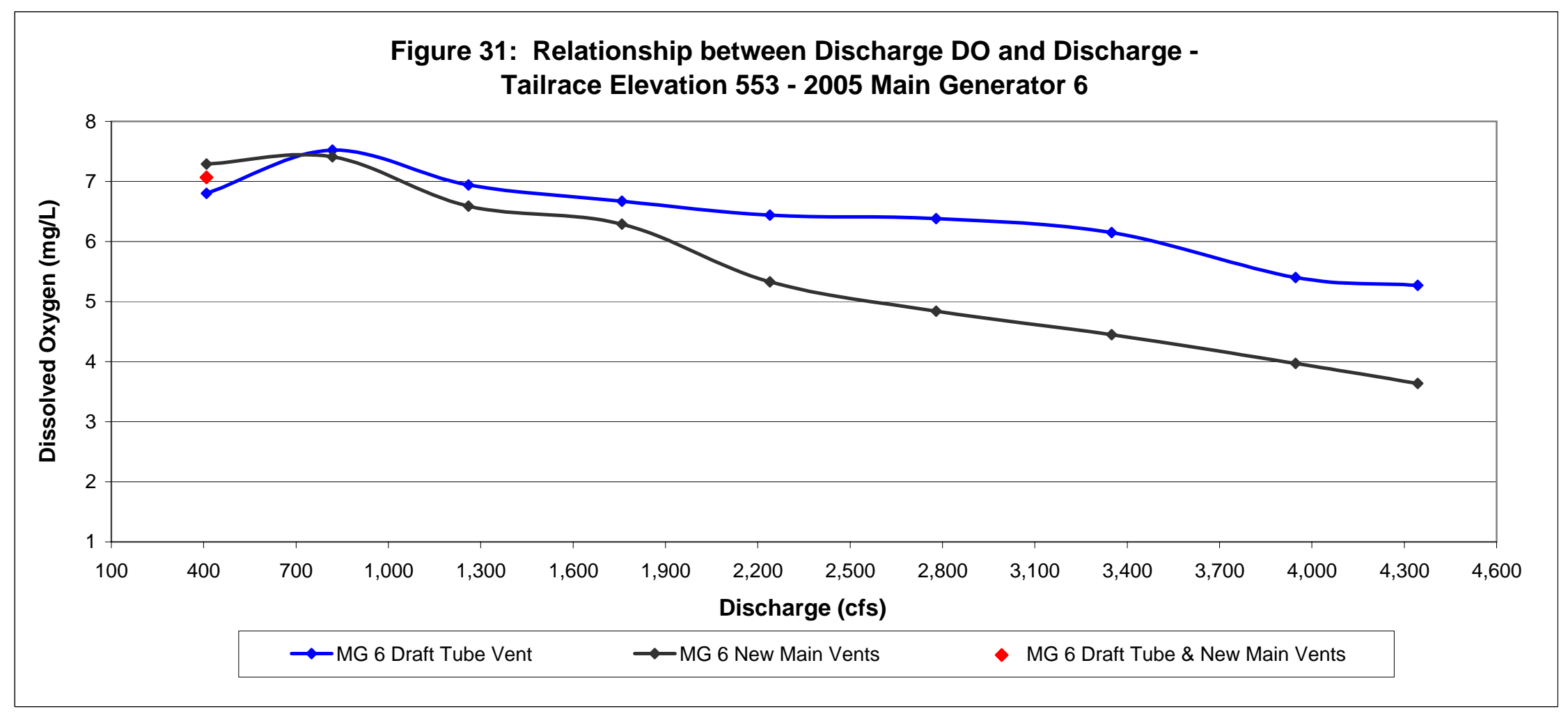




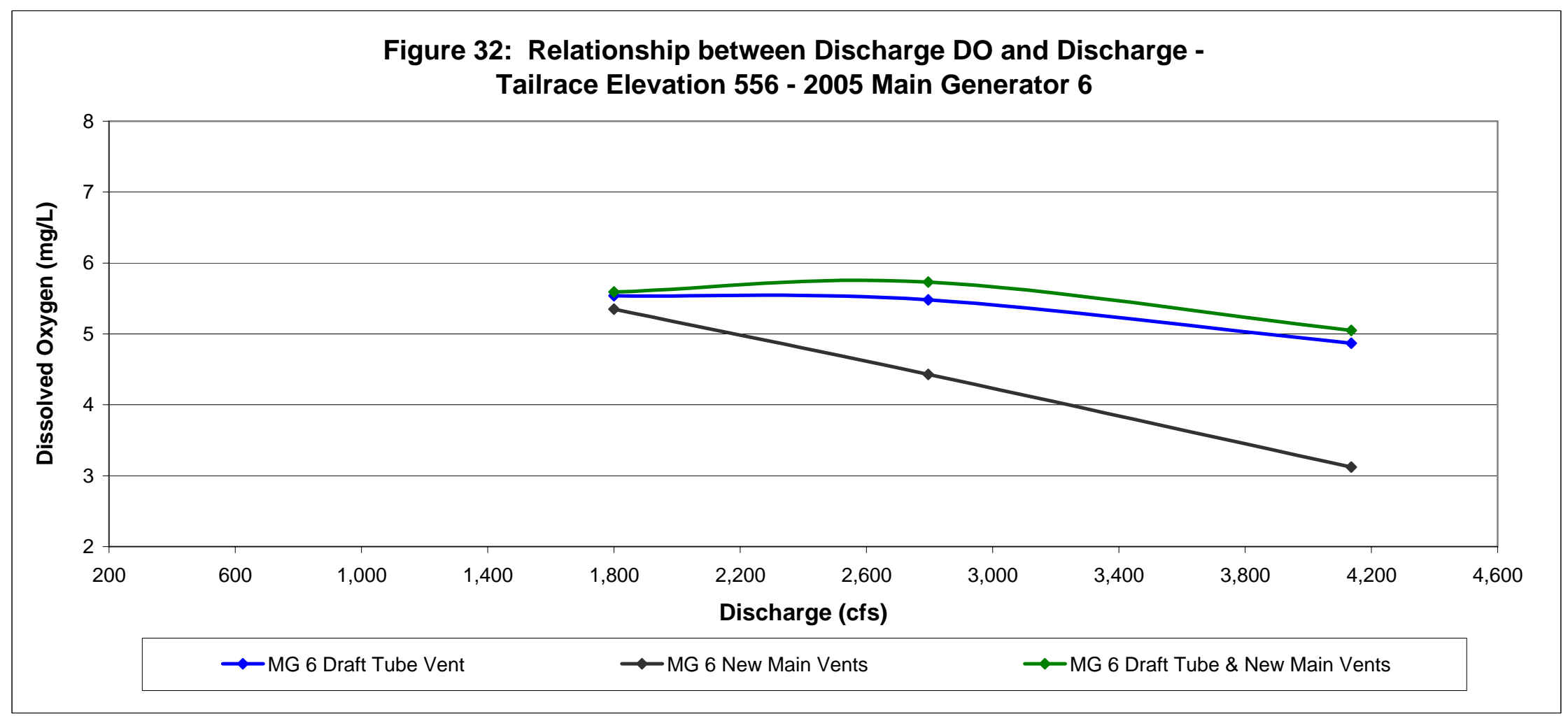




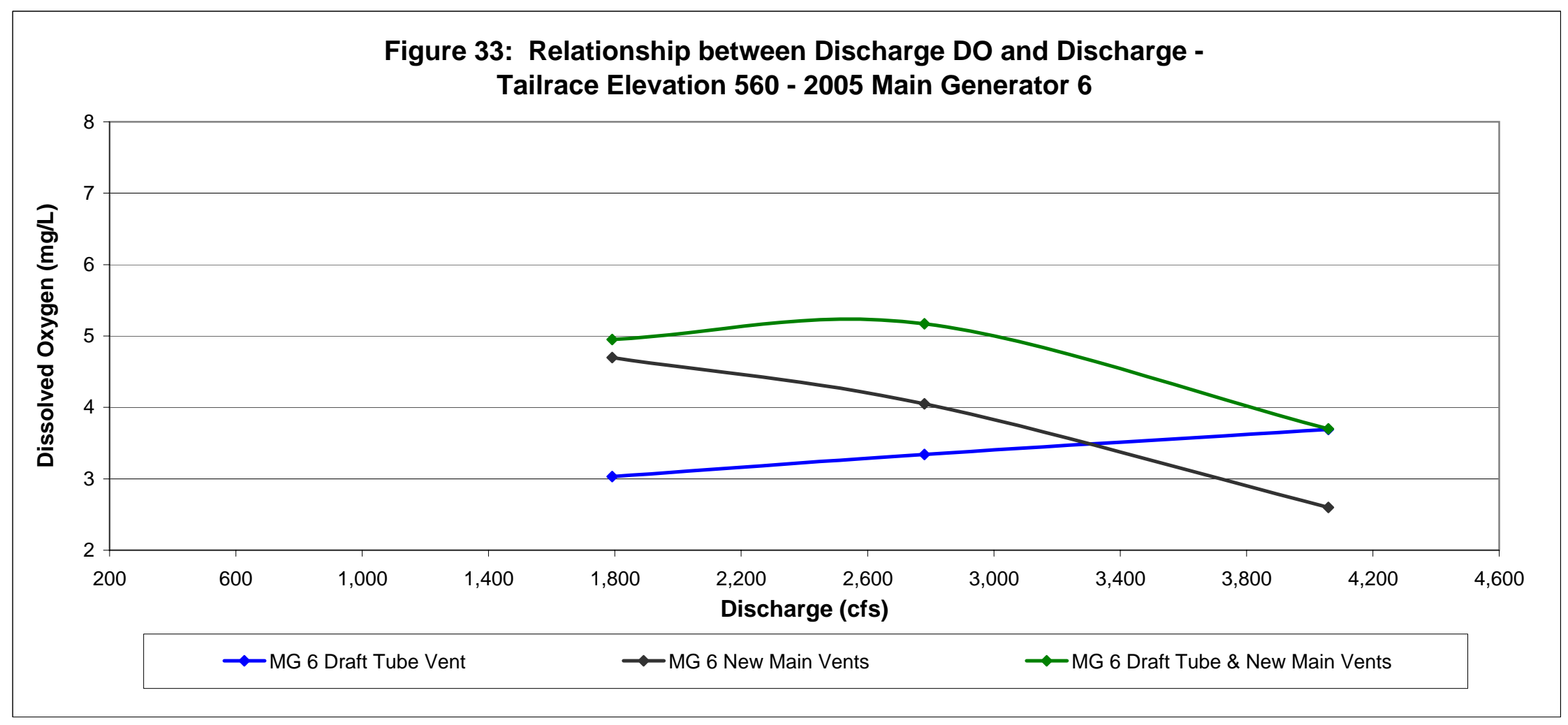




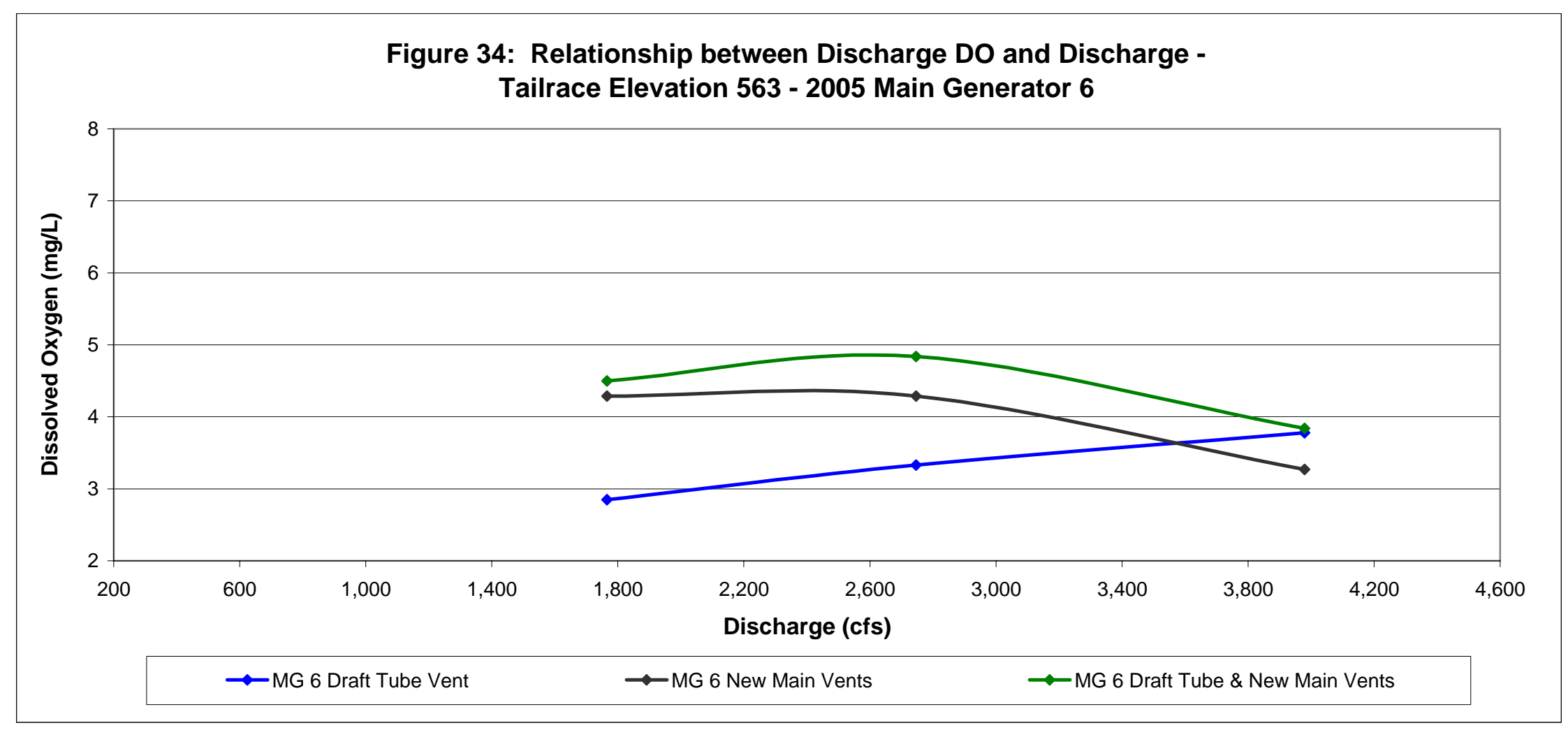




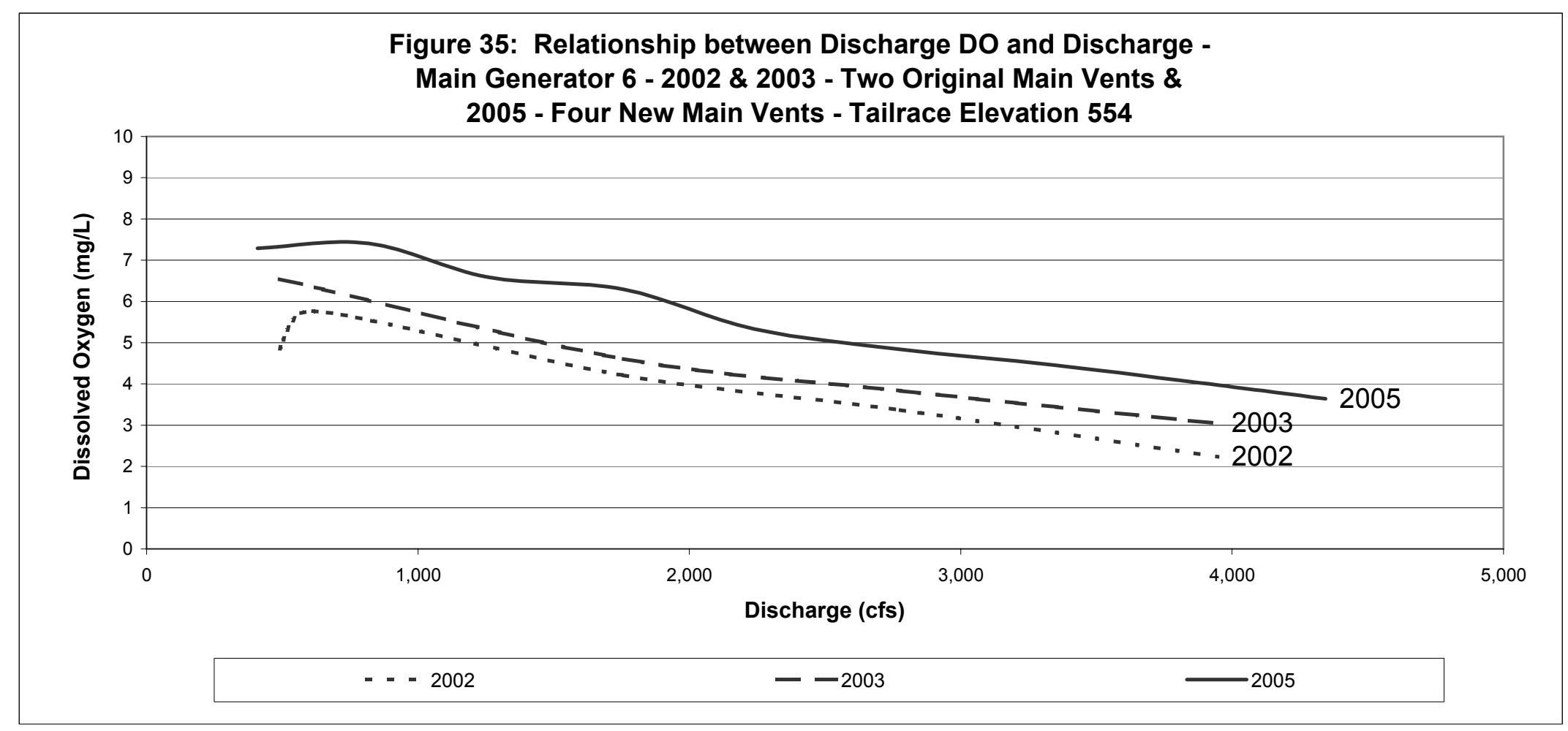




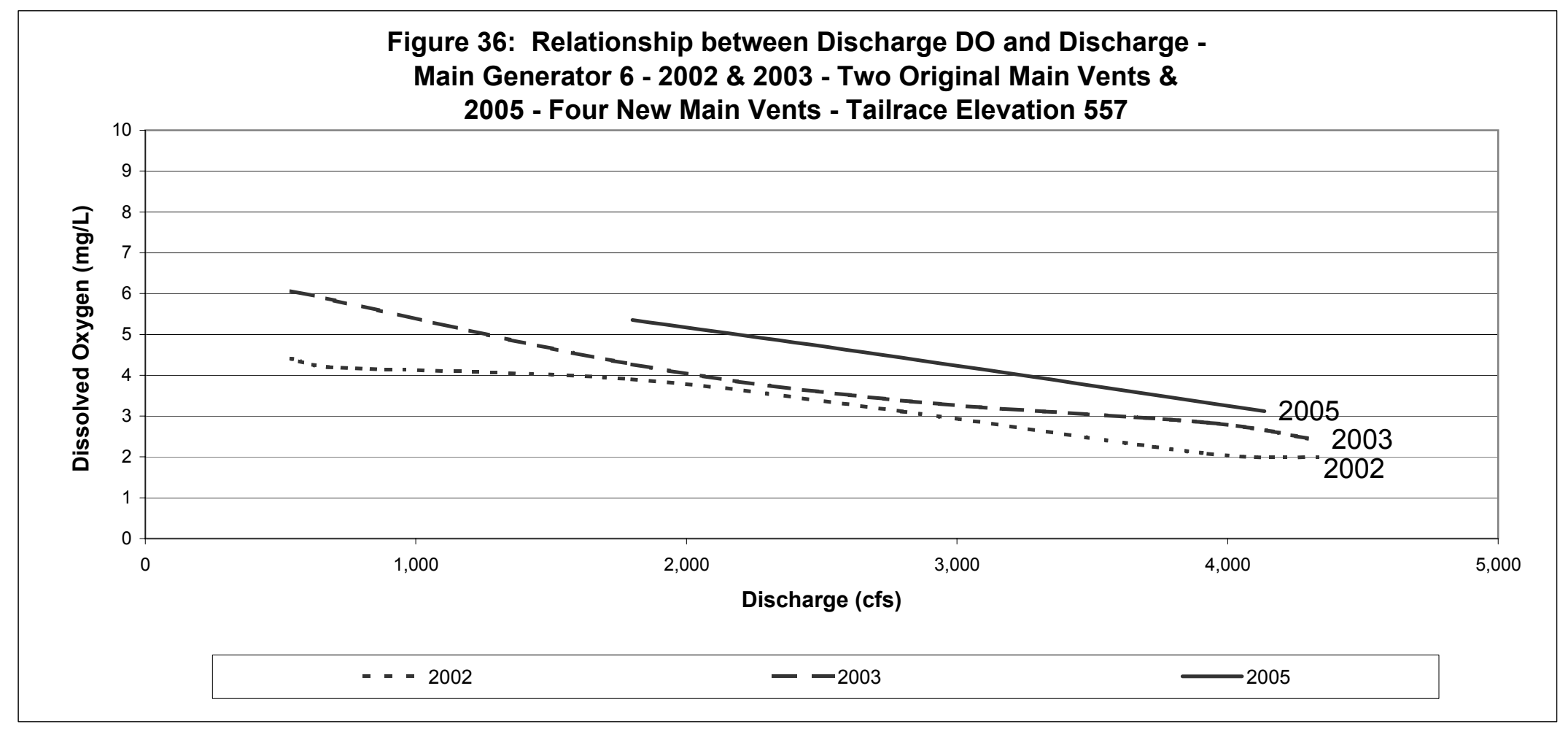




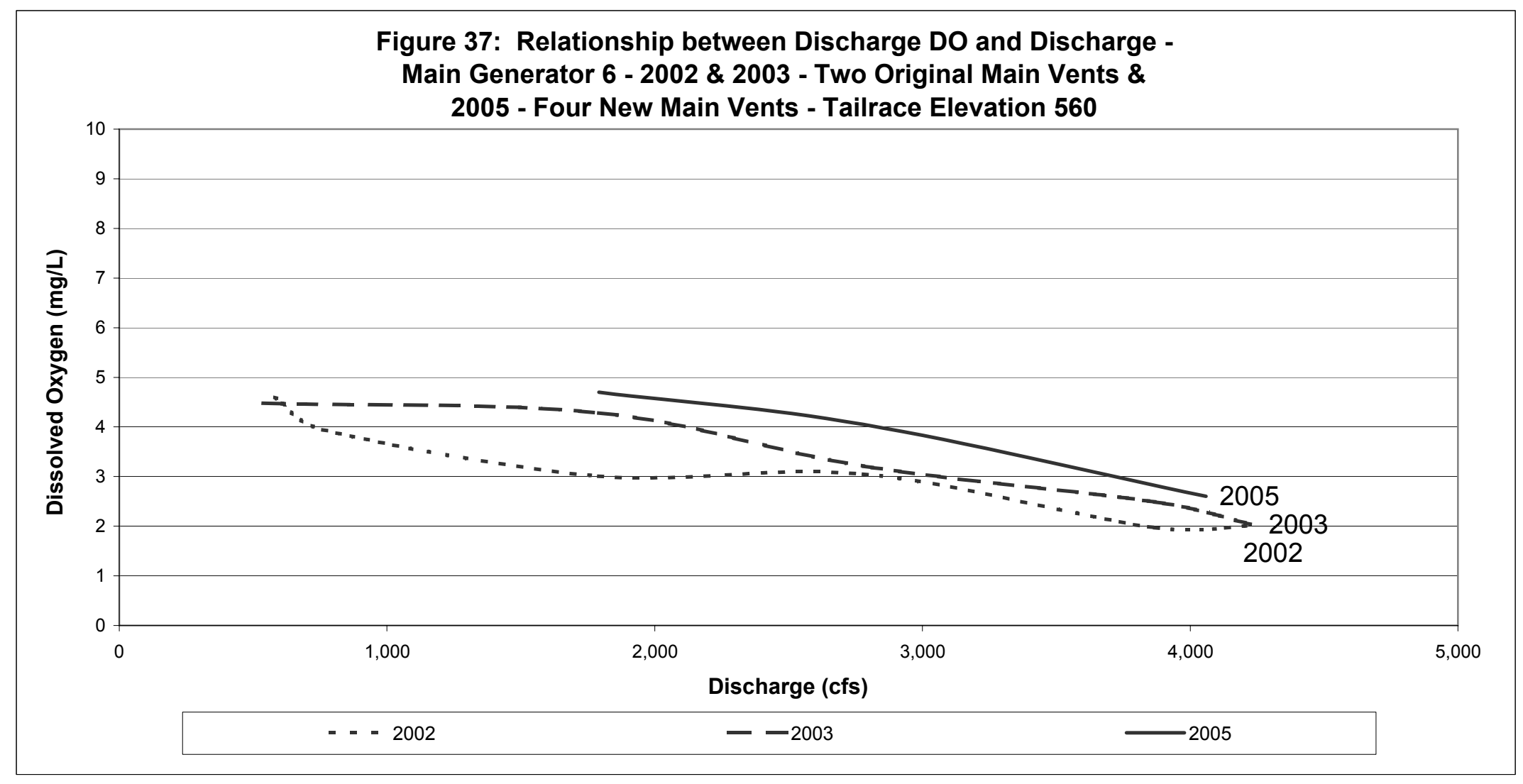




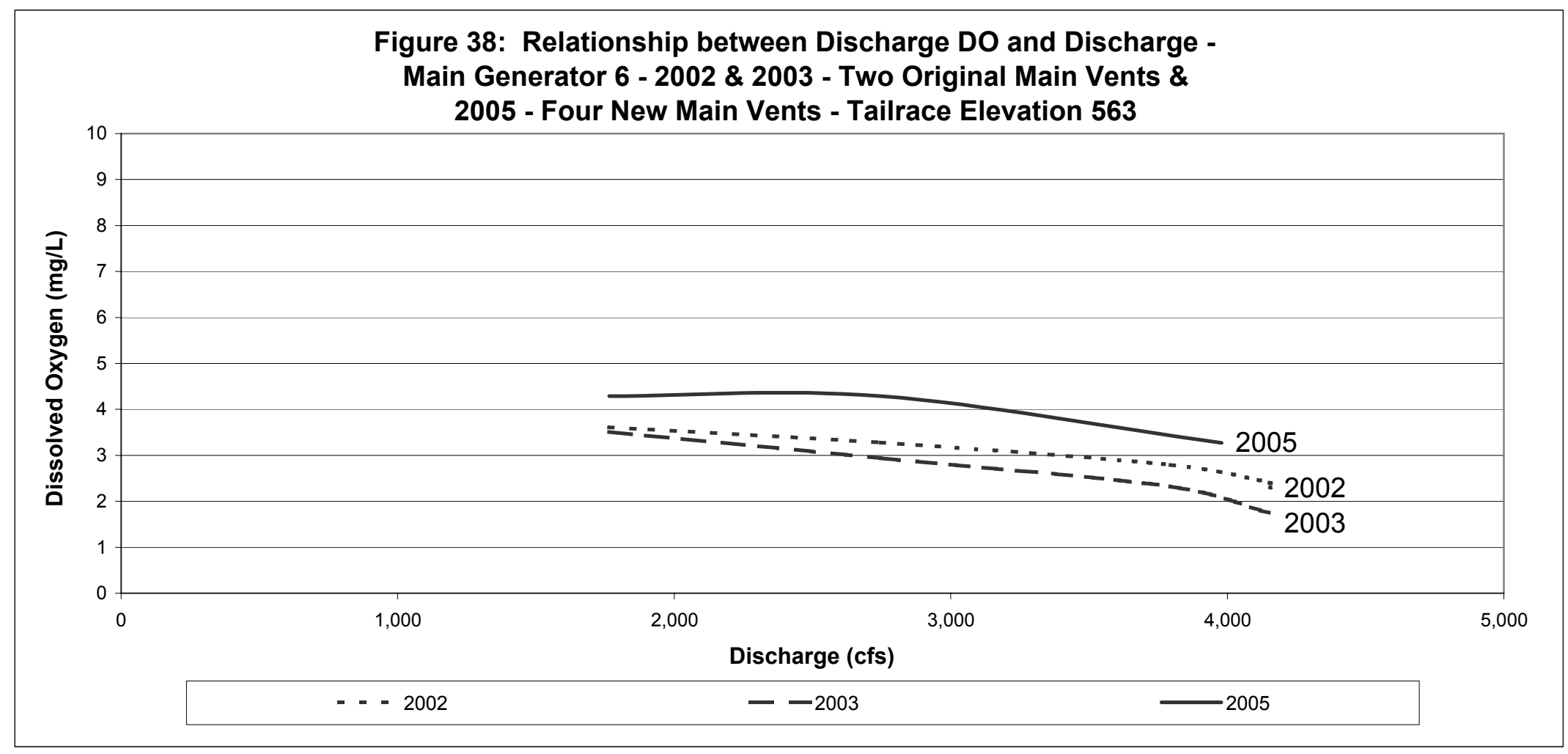




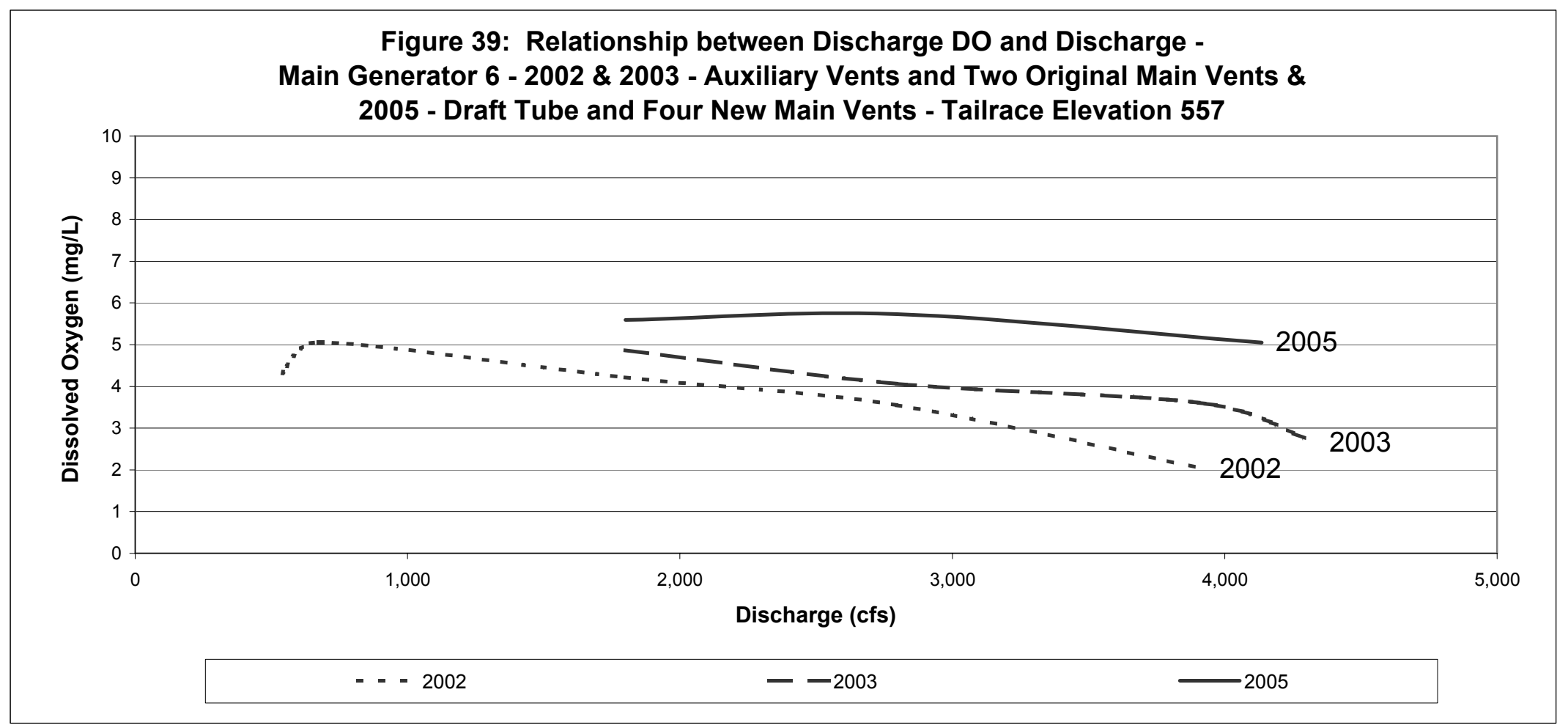




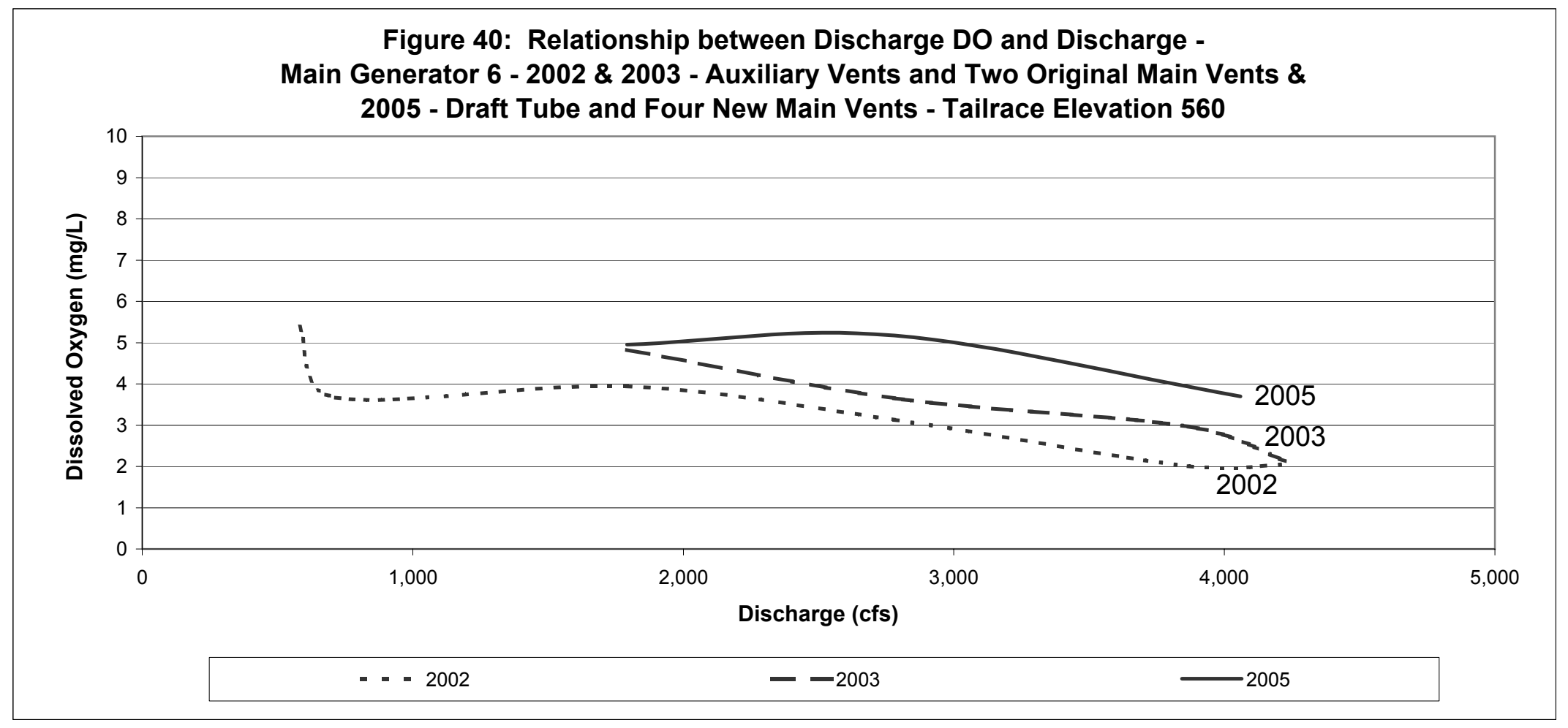




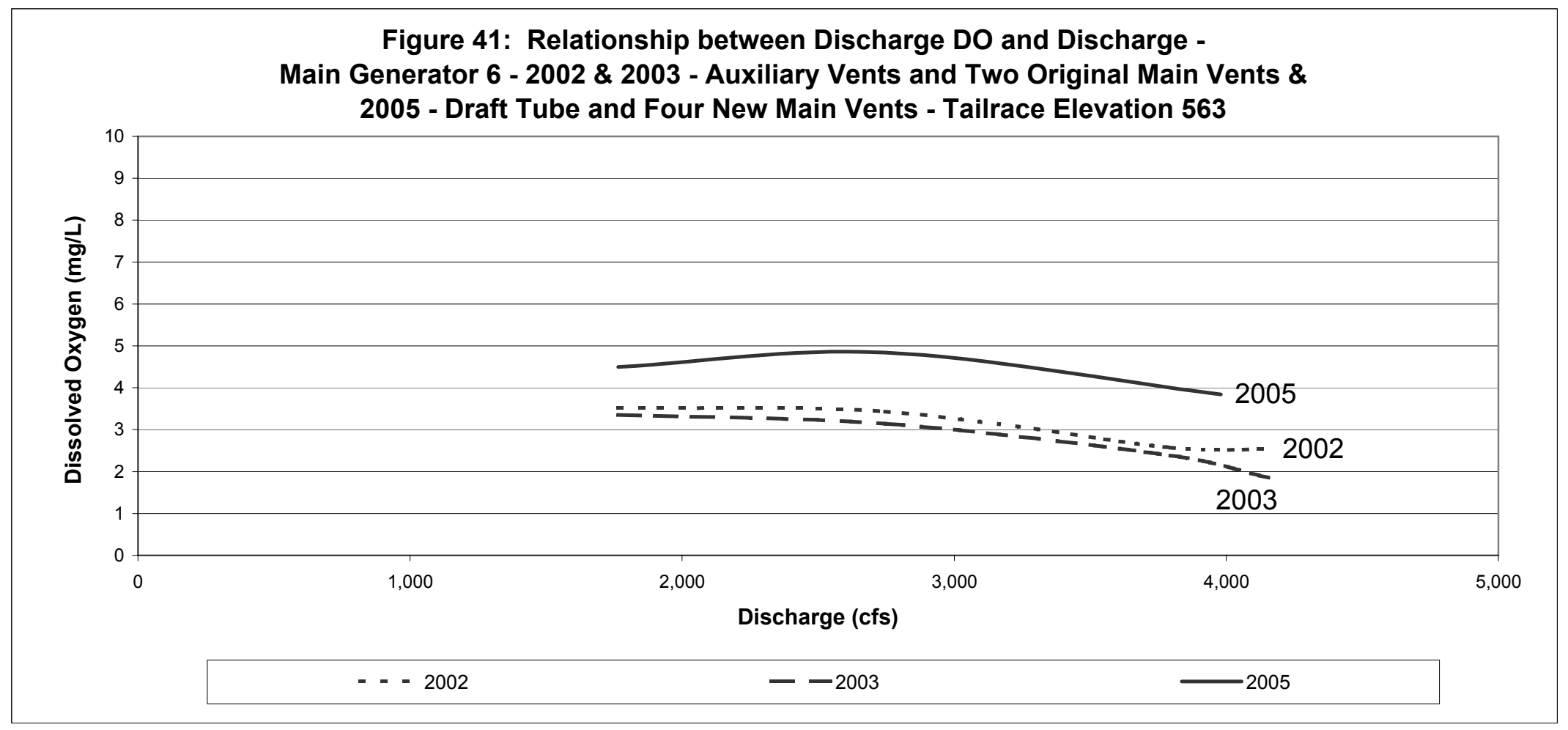




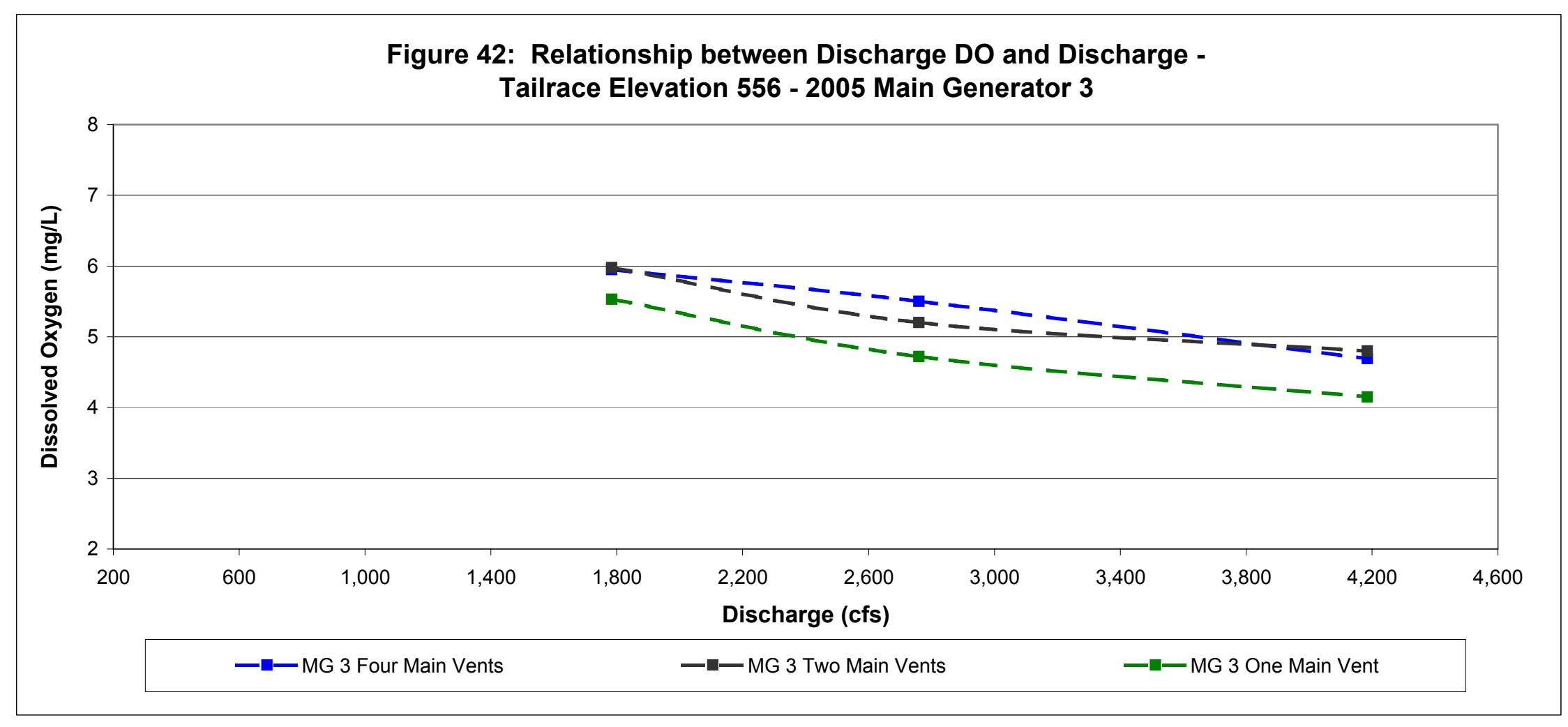




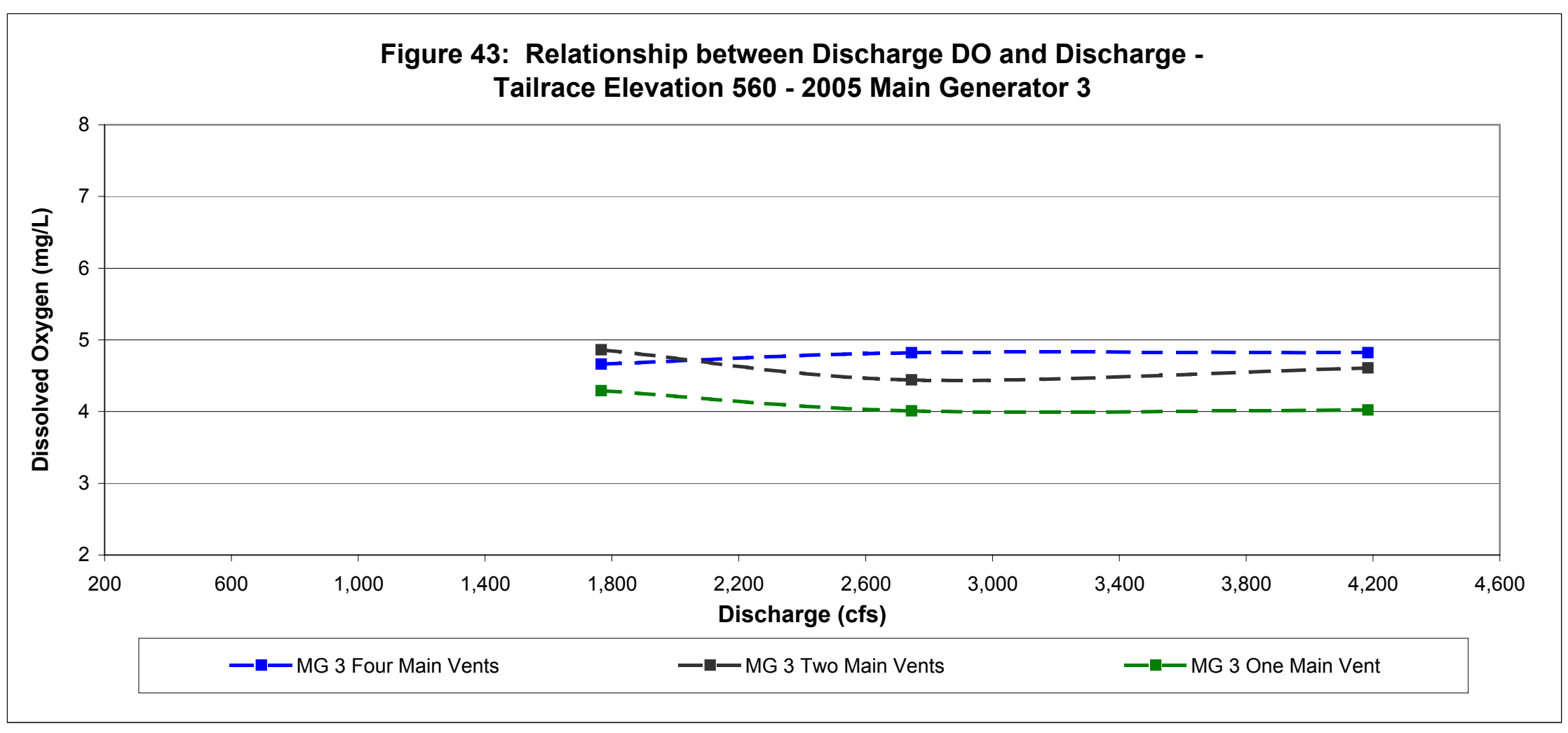




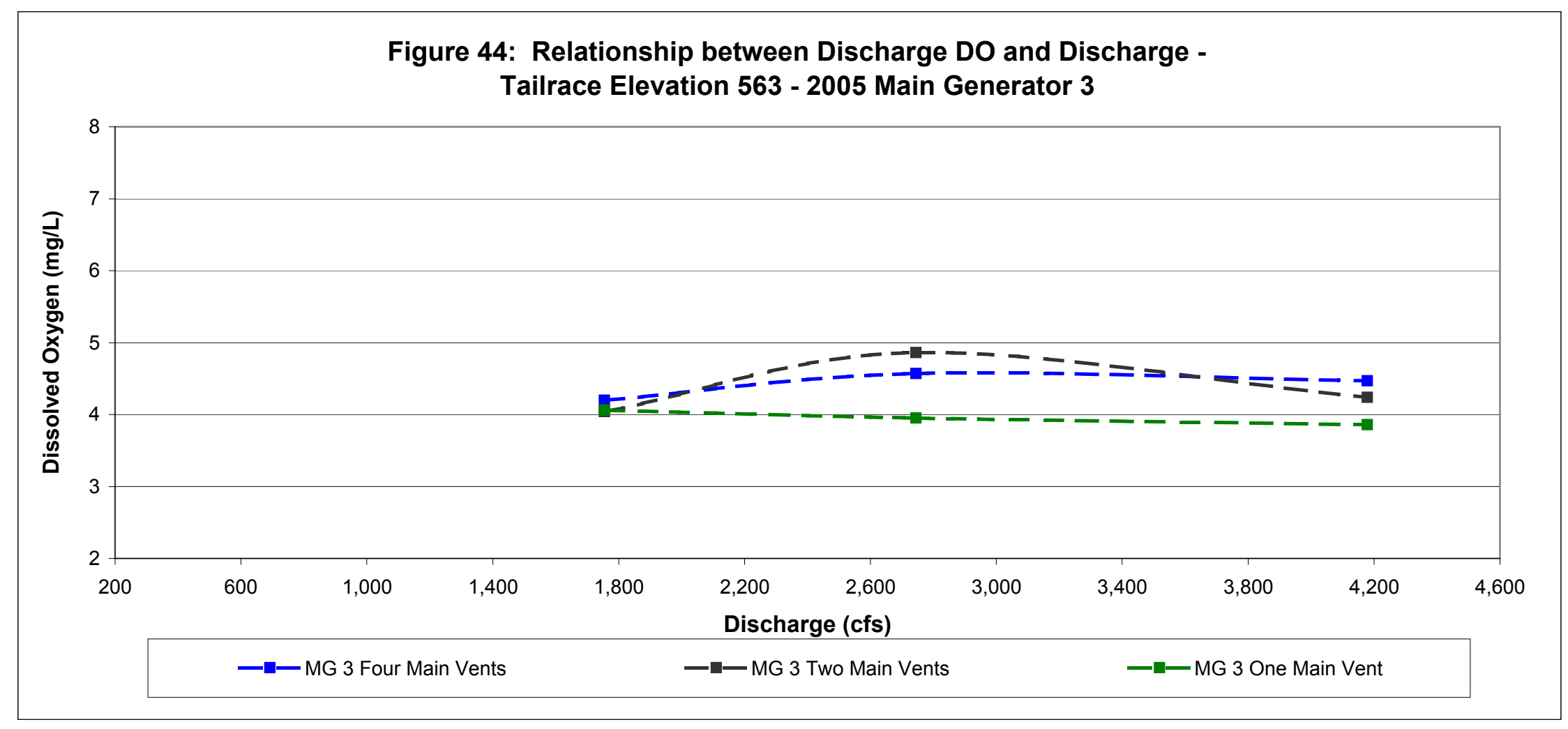




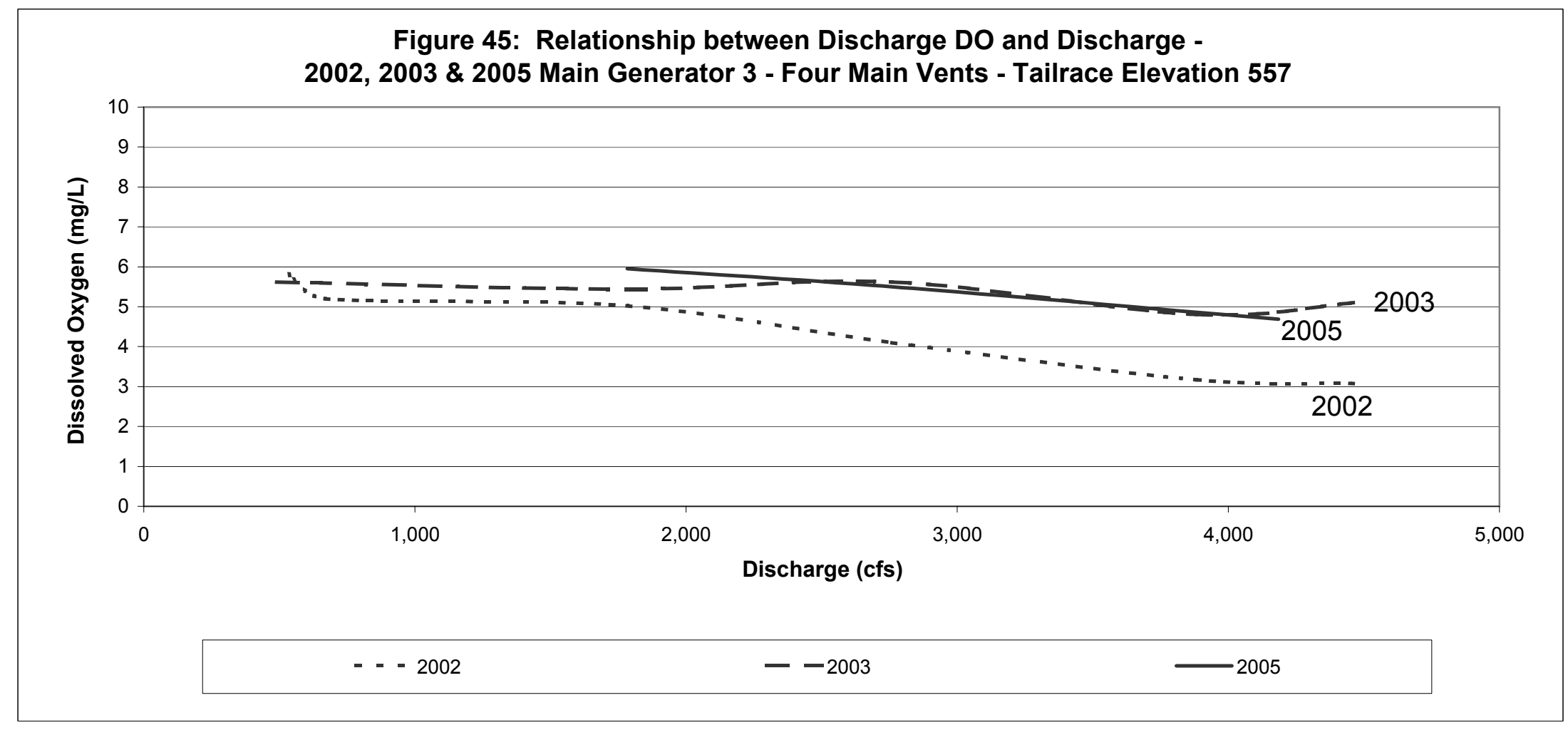




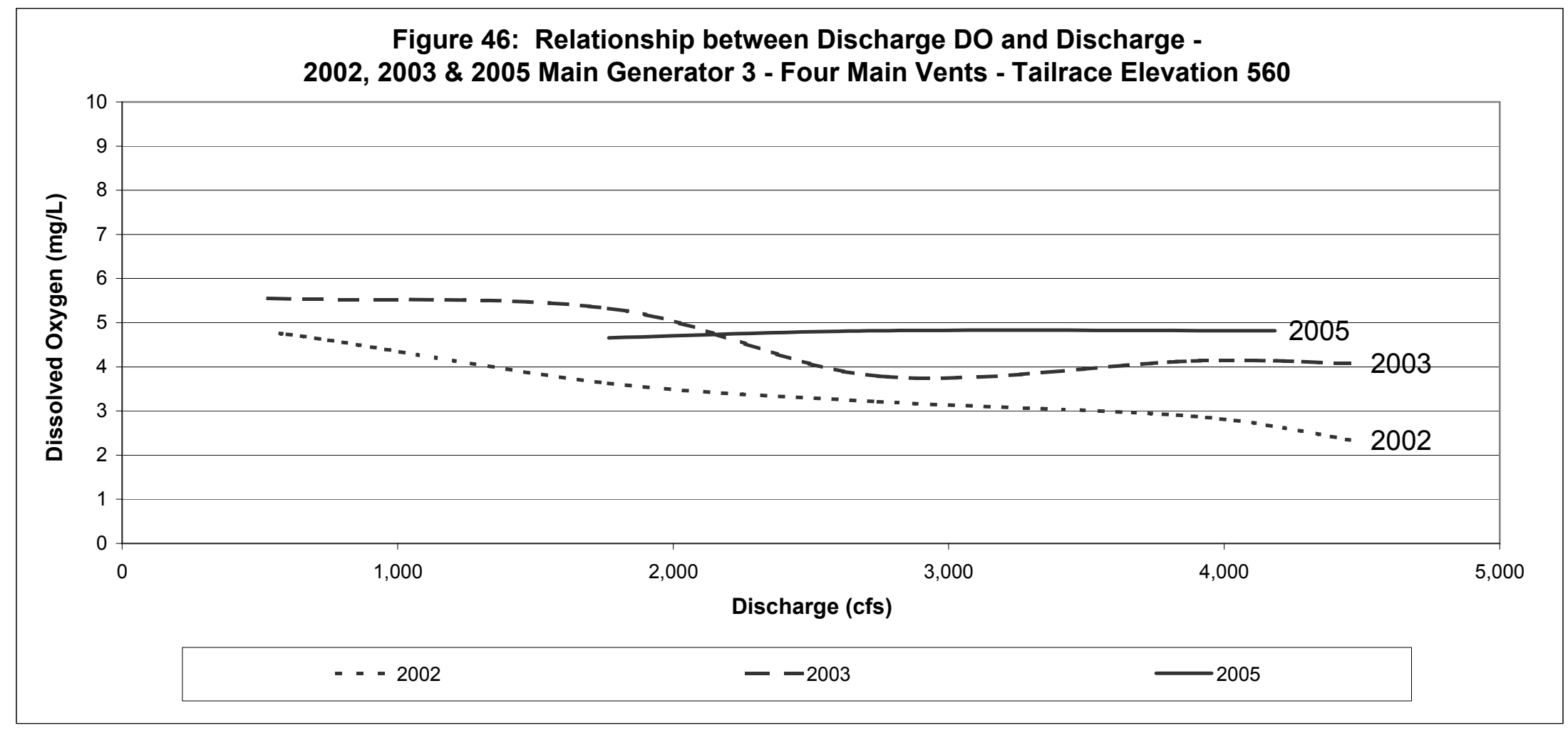




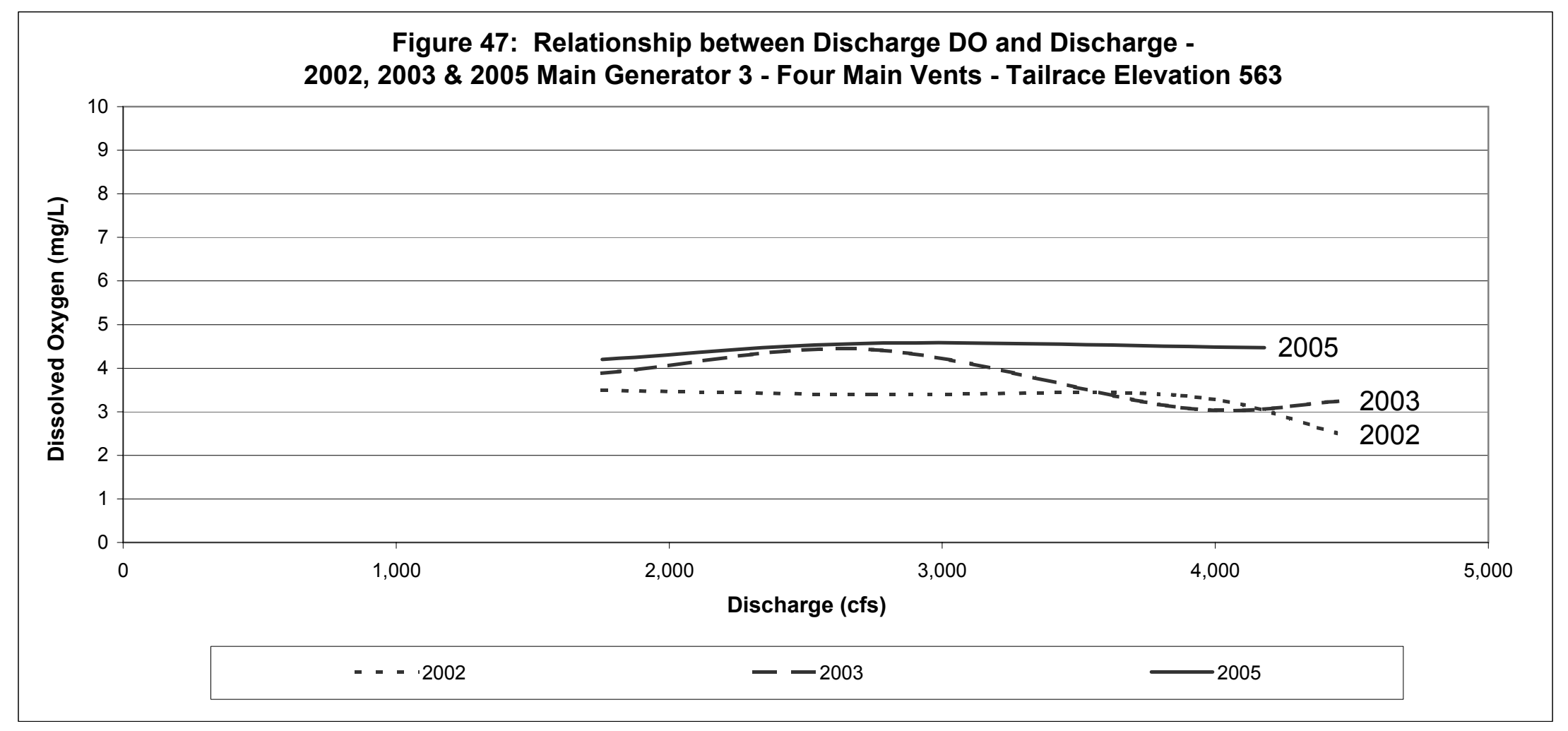




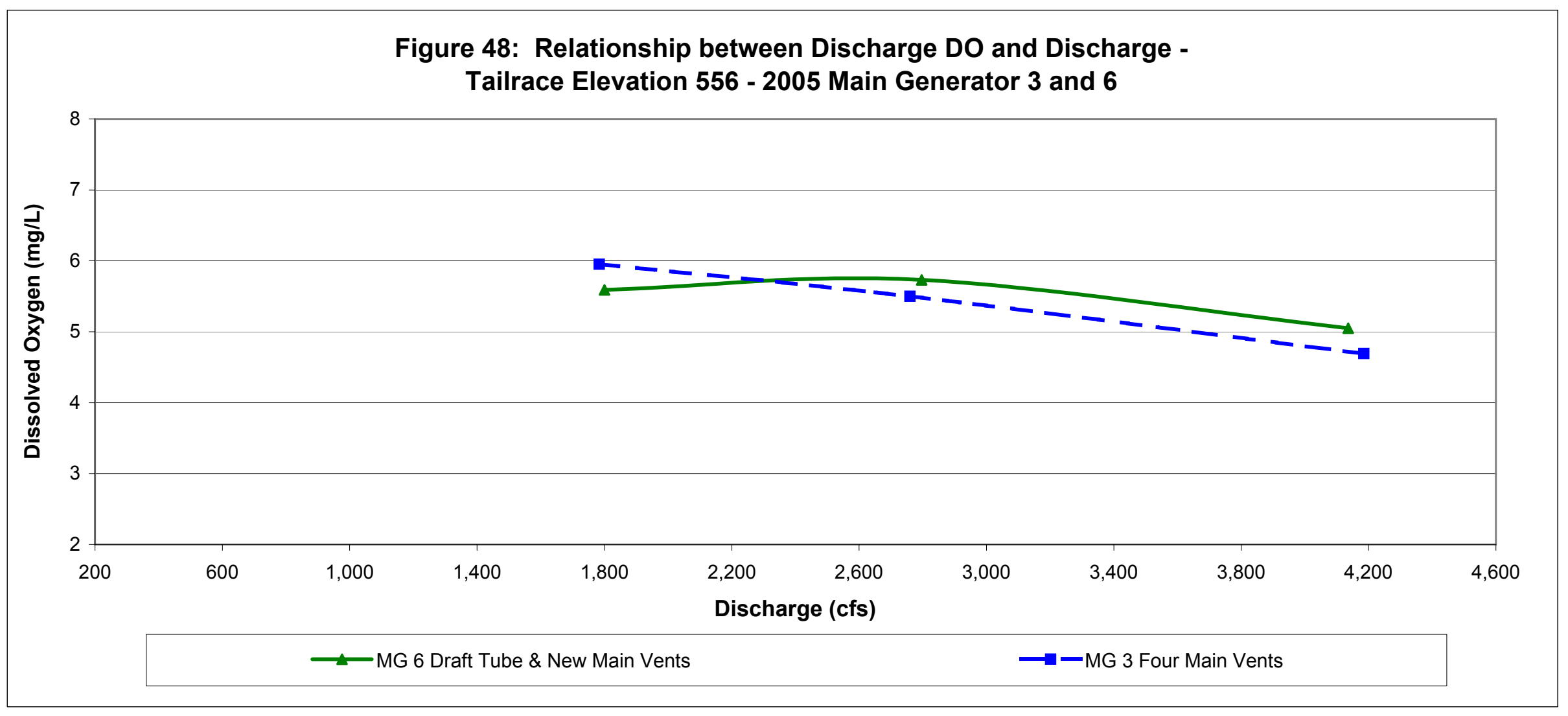




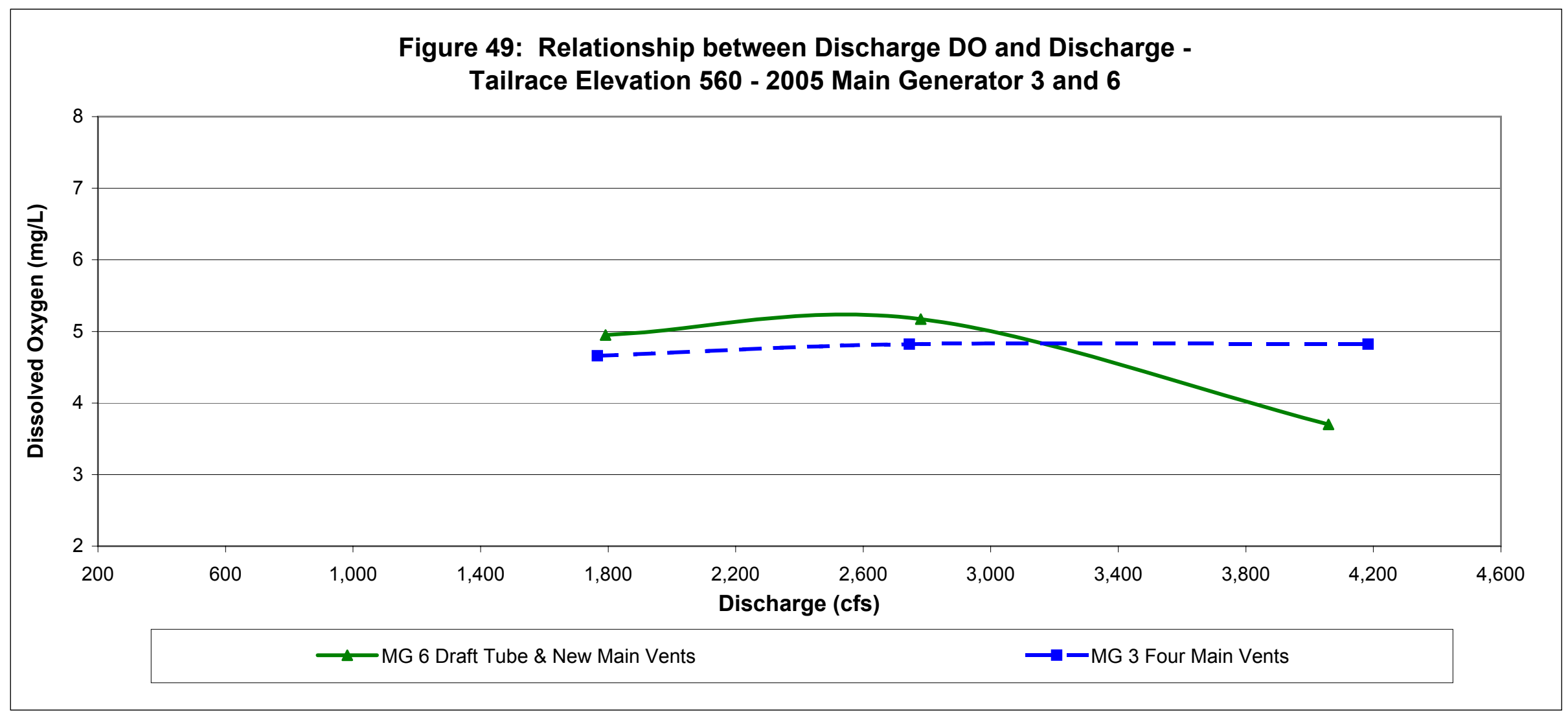




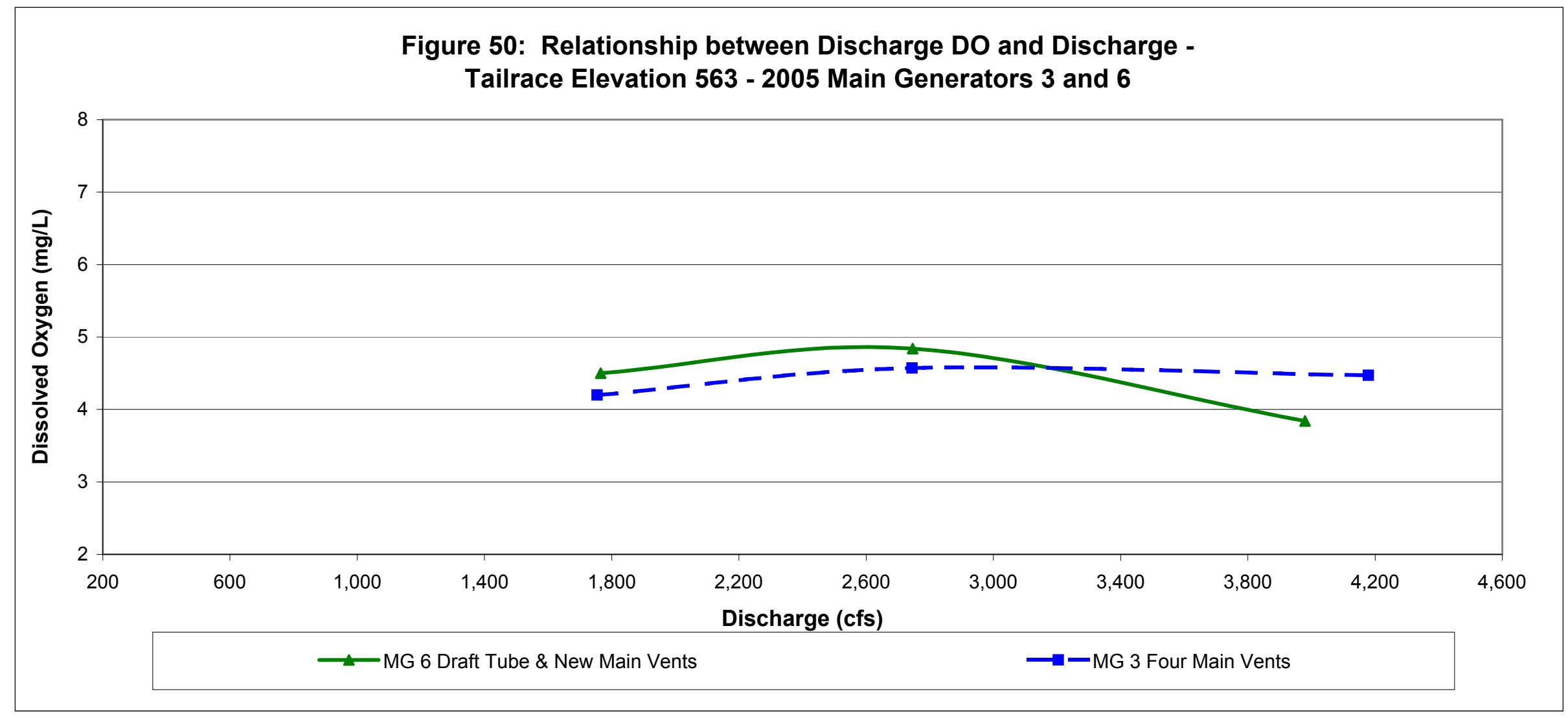




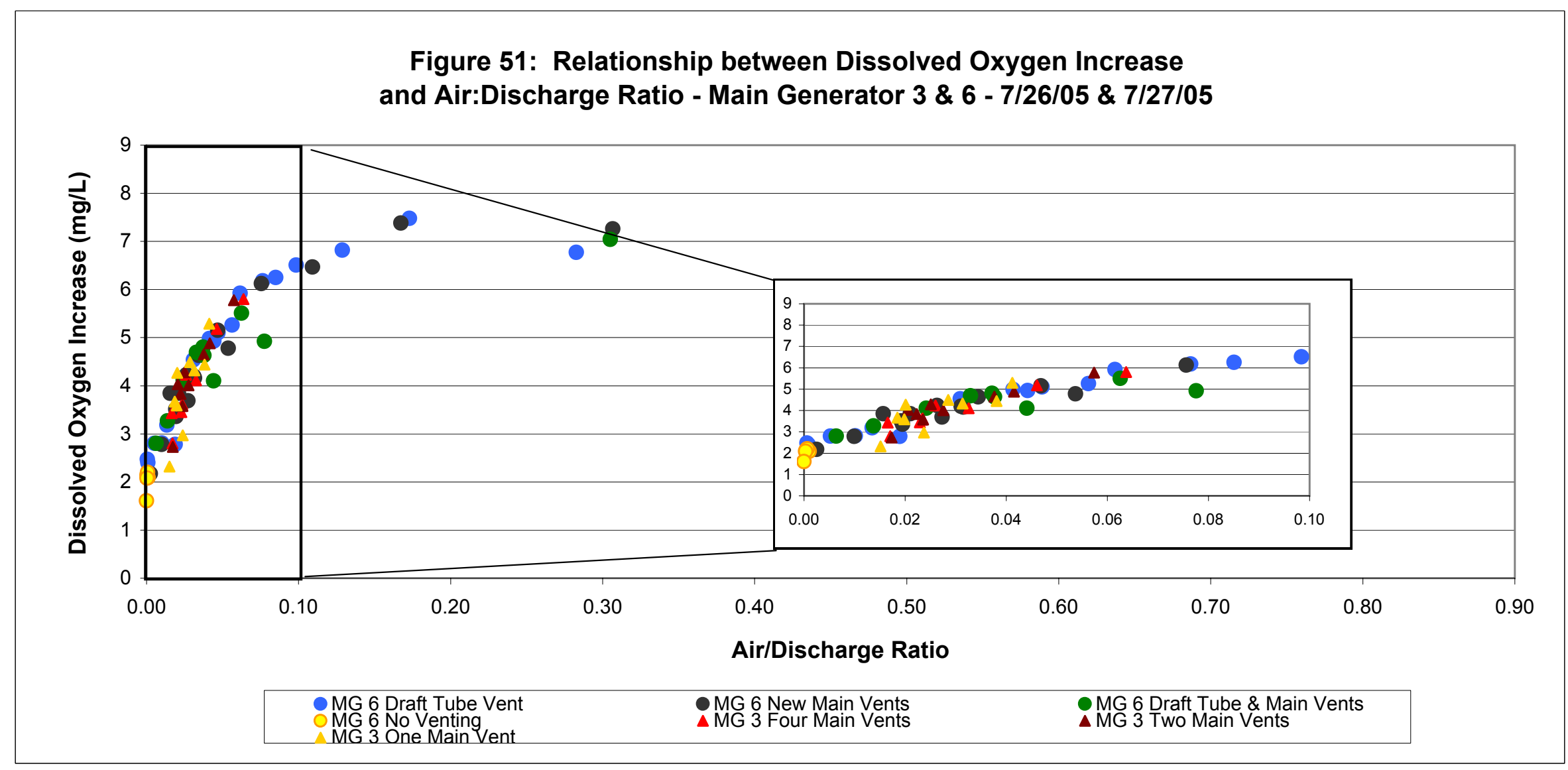

Dissolved Oxgyen Increase is the difference between the study unit discharge dissolved oxygen and the study unit intake dissolved oxygen. 


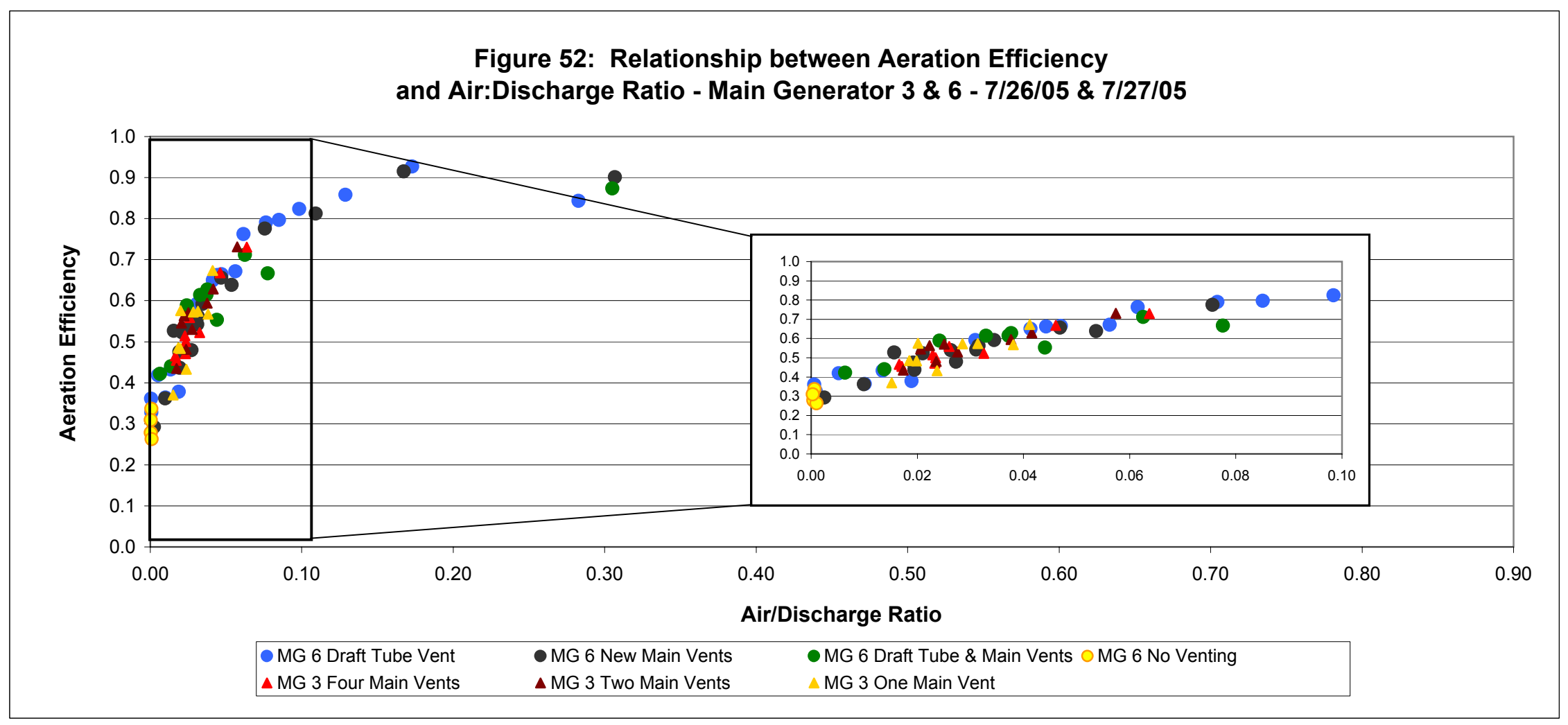

Aeration Efficiency is the ability of the study unit to increase the inlet water dissolved oxygen concentrations to saturation concentrations. Aeration Effeciency $=\left(C_{D^{-}}\right.$ $\left.C_{i}\right) /\left(C_{S}-C_{i}\right)$ where $C_{D}=$ Dissolved Oxygen Concentration in the Discharge Water, and $C_{i}=$ Dissolved Oxygen Concentration in the Inlet Water, and $C_{S}=$ Dissolved Oxygen Concentration at Saturation 


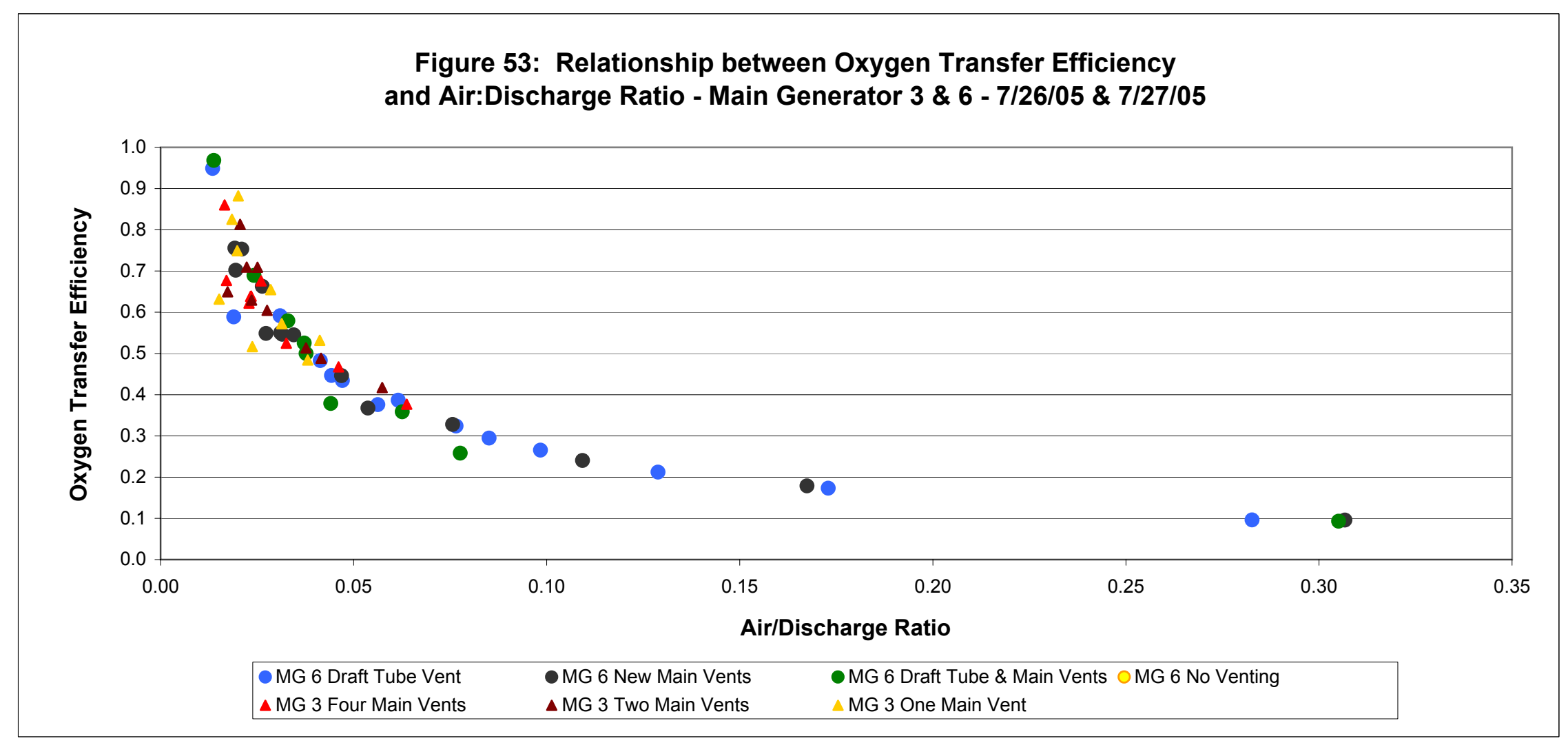

Oxygen Transfer Efficiency is a measure of the study unit's ability to transfer oxygen from the air entering the unit into the water entering the unit. Oxygen Transfer Efficiency $=$ Mass of $\mathrm{O}_{2}$ (lbs) transferred to water/mass of $\mathrm{O}_{2}$ (lbs) from airflow 


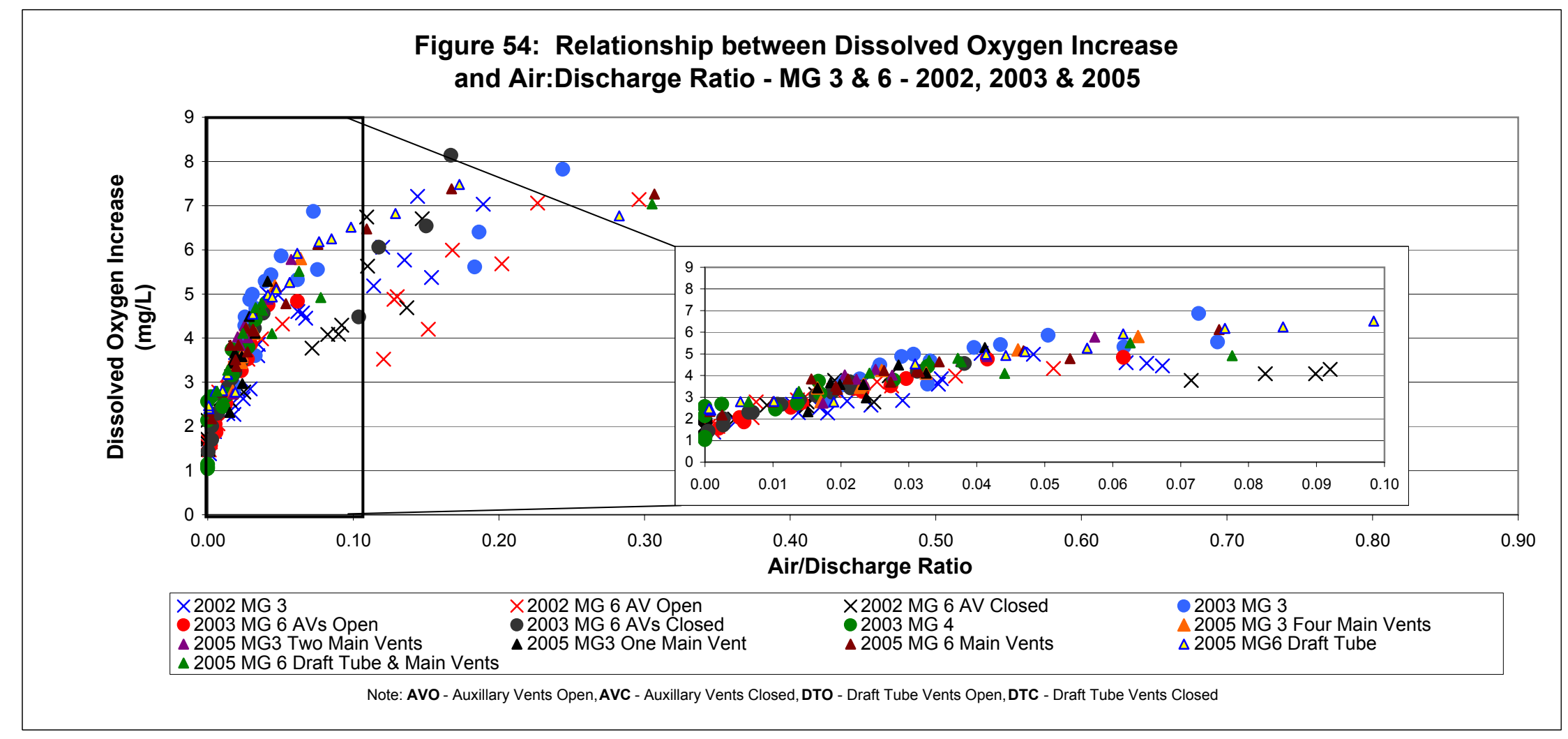

Dissolved Oxgyen Increase is the difference between the tailrace dissolved oxygen and the intake dissolved oxygen. 


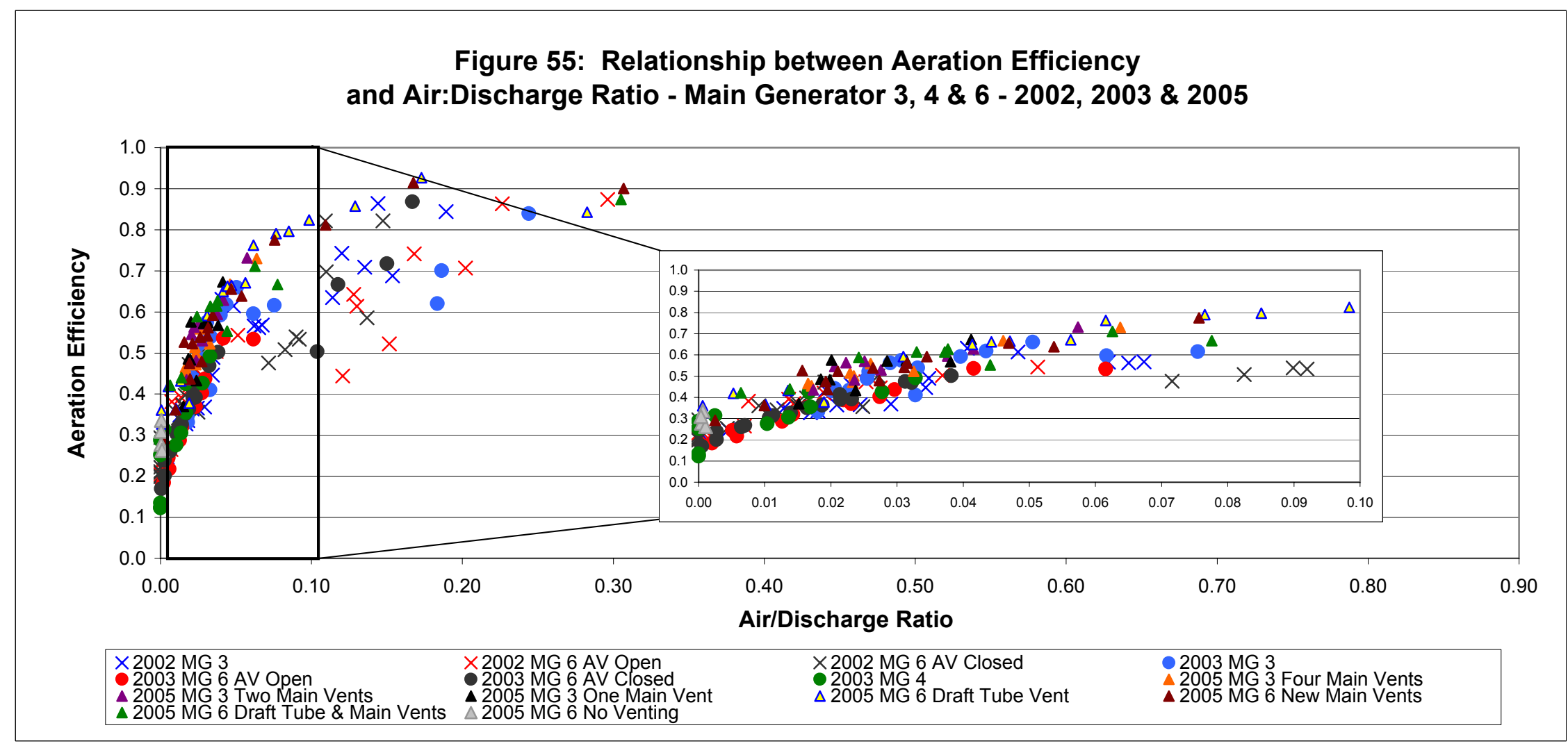

Aeration Efficiency is the ability of the study unit to increase the inlet water dissolved oxygen concentrations to saturation concentrations. Aeration Effeciency $=\left(C_{D^{-}}\right.$ $\left.C_{i}\right) /\left(C_{S}-C_{i}\right)$ where $C_{D}=$ Dissolved Oxygen Concentration in the Discharge Water, and $C_{i}=$ Dissolved Oxygen Concentration in the Inlet Water, and $C_{S}=$ Dissolved Oxygen Concentration at Saturation 


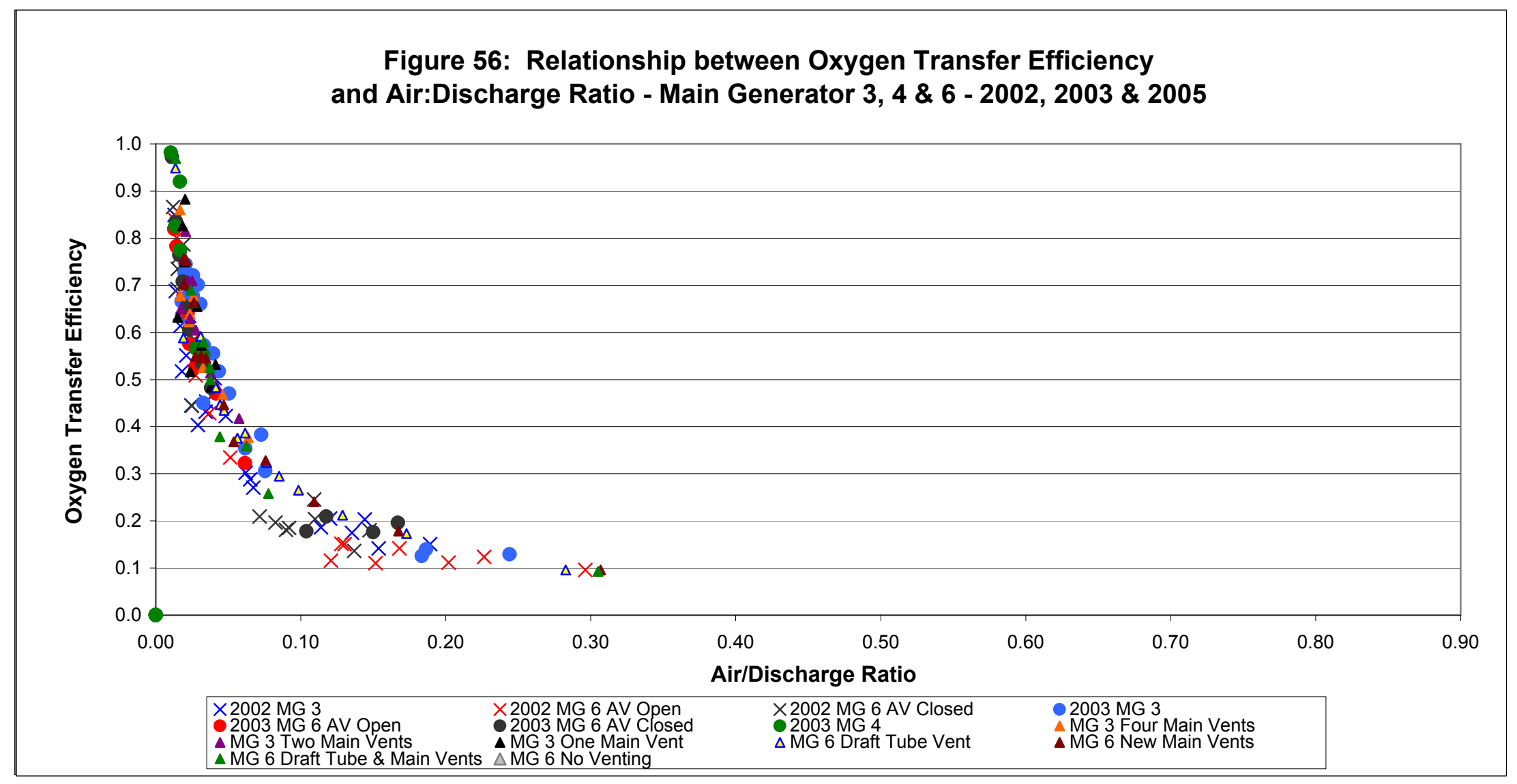

Oxygen Transfer Efficiency is a measure of the study unit's ability to transfer oxygen from the air entering the unit into the water entering the unit. Oxygen Transfer Efficiency $=$ Mass of $\mathrm{O}_{2}$ (Ibs) transferred to water/mass of $\mathrm{O}_{2}$ (lbs) from airflow 


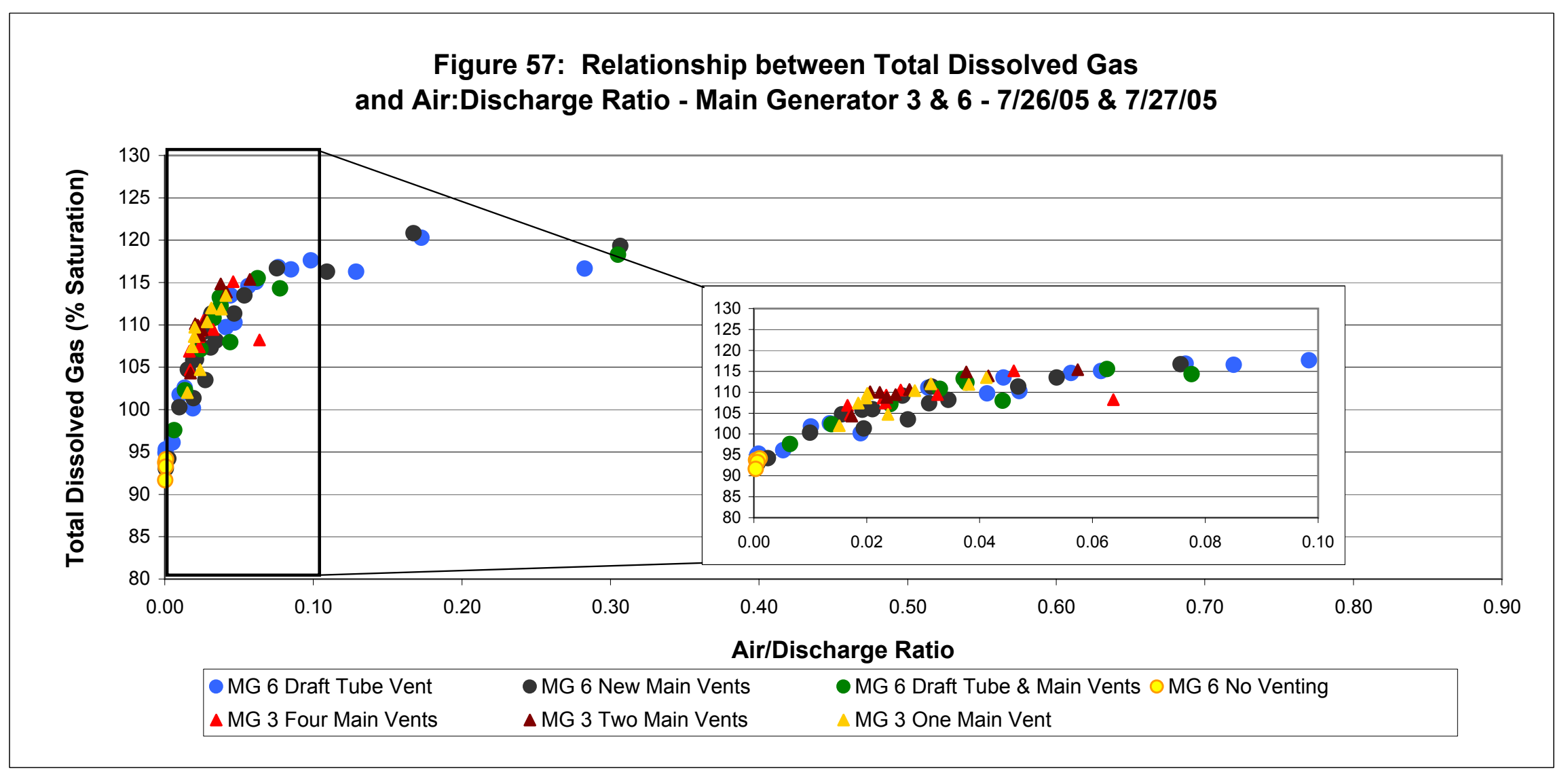




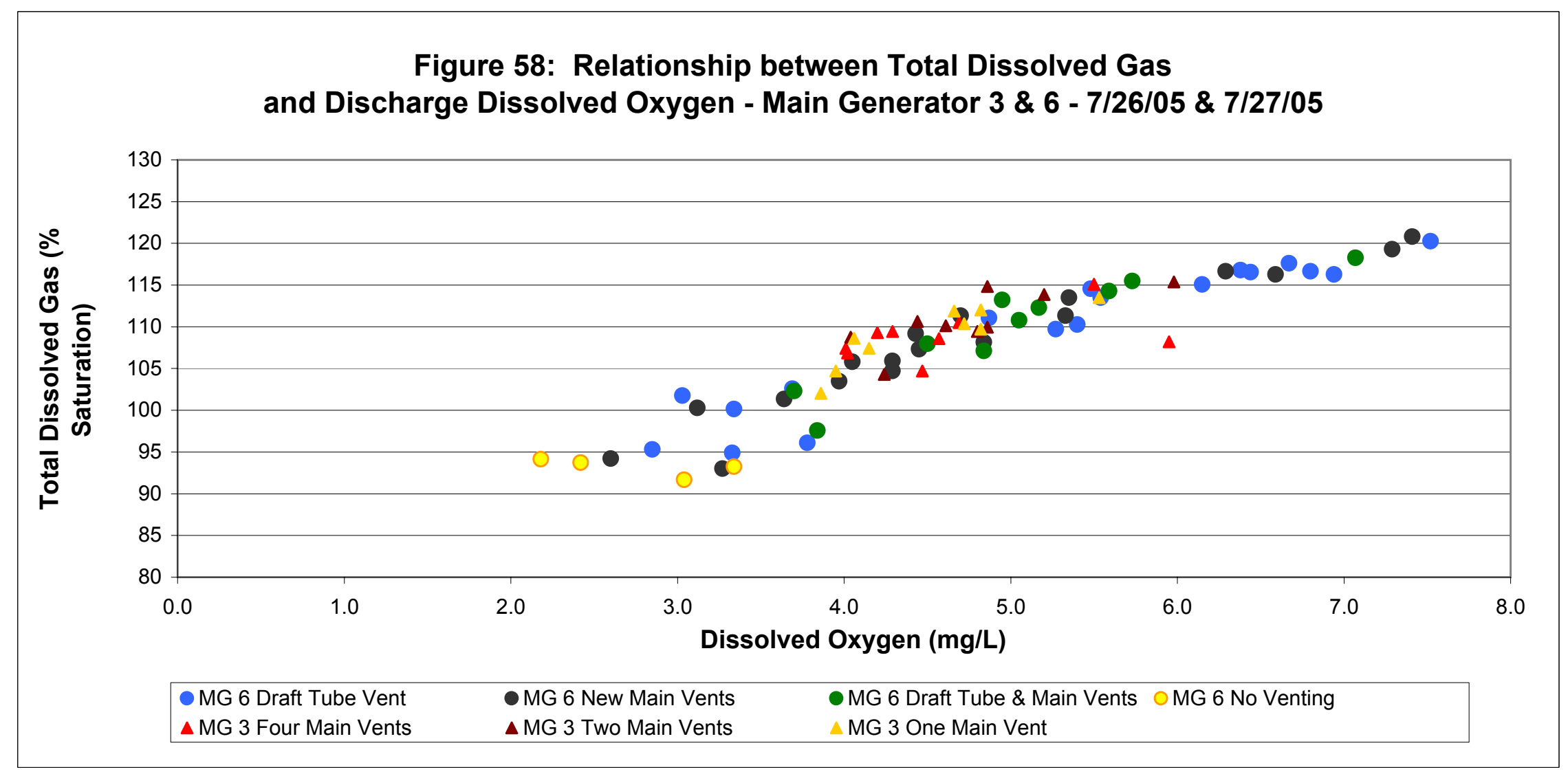

Discharge Dissolved Oxygen that which was measured in the discharge boil of the study unit. 


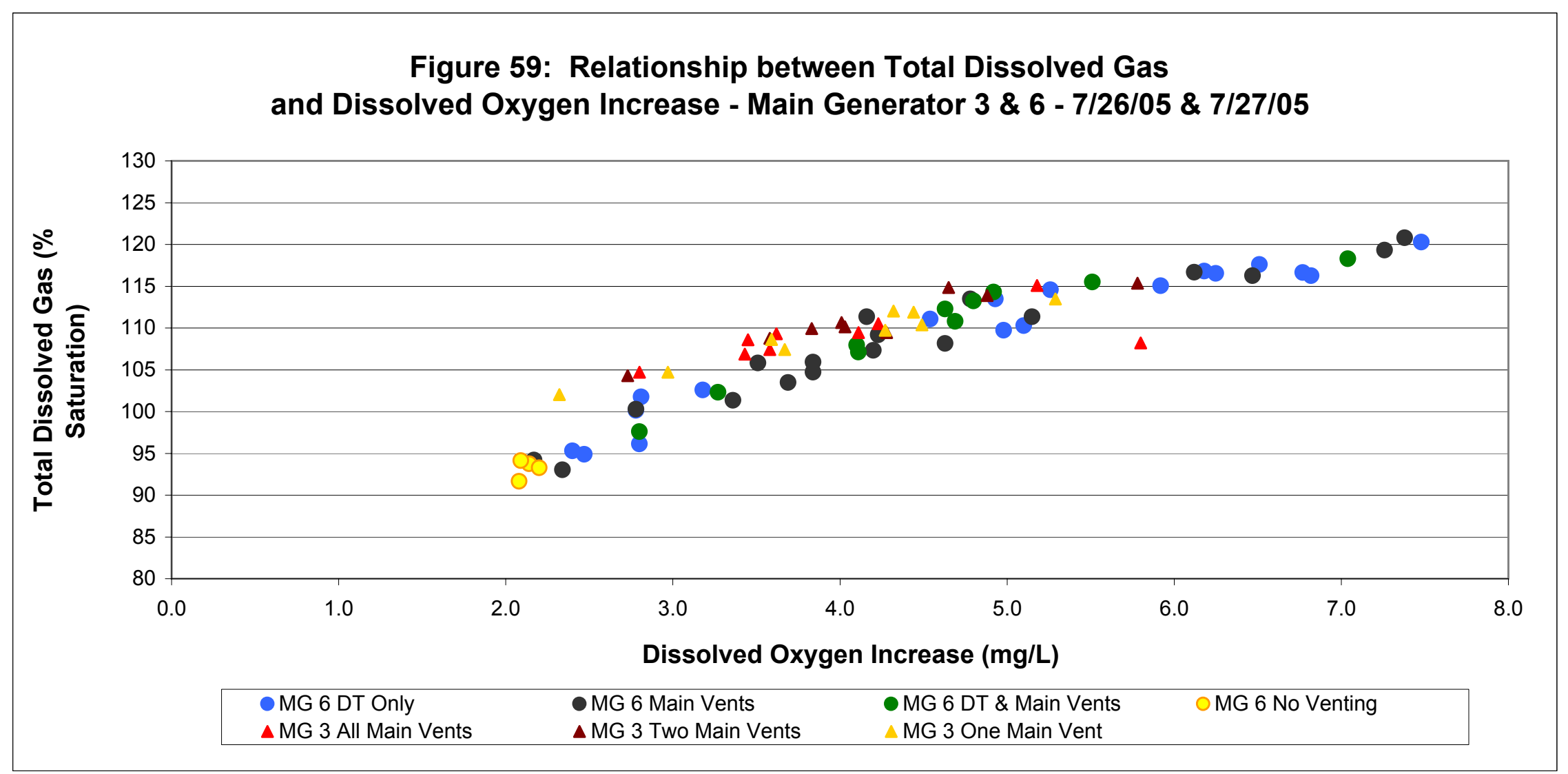

Dissolved Oxgyen Increase is the difference between the study unit discharge dissolved oxygen and the study unit intake dissolved oxygen. 


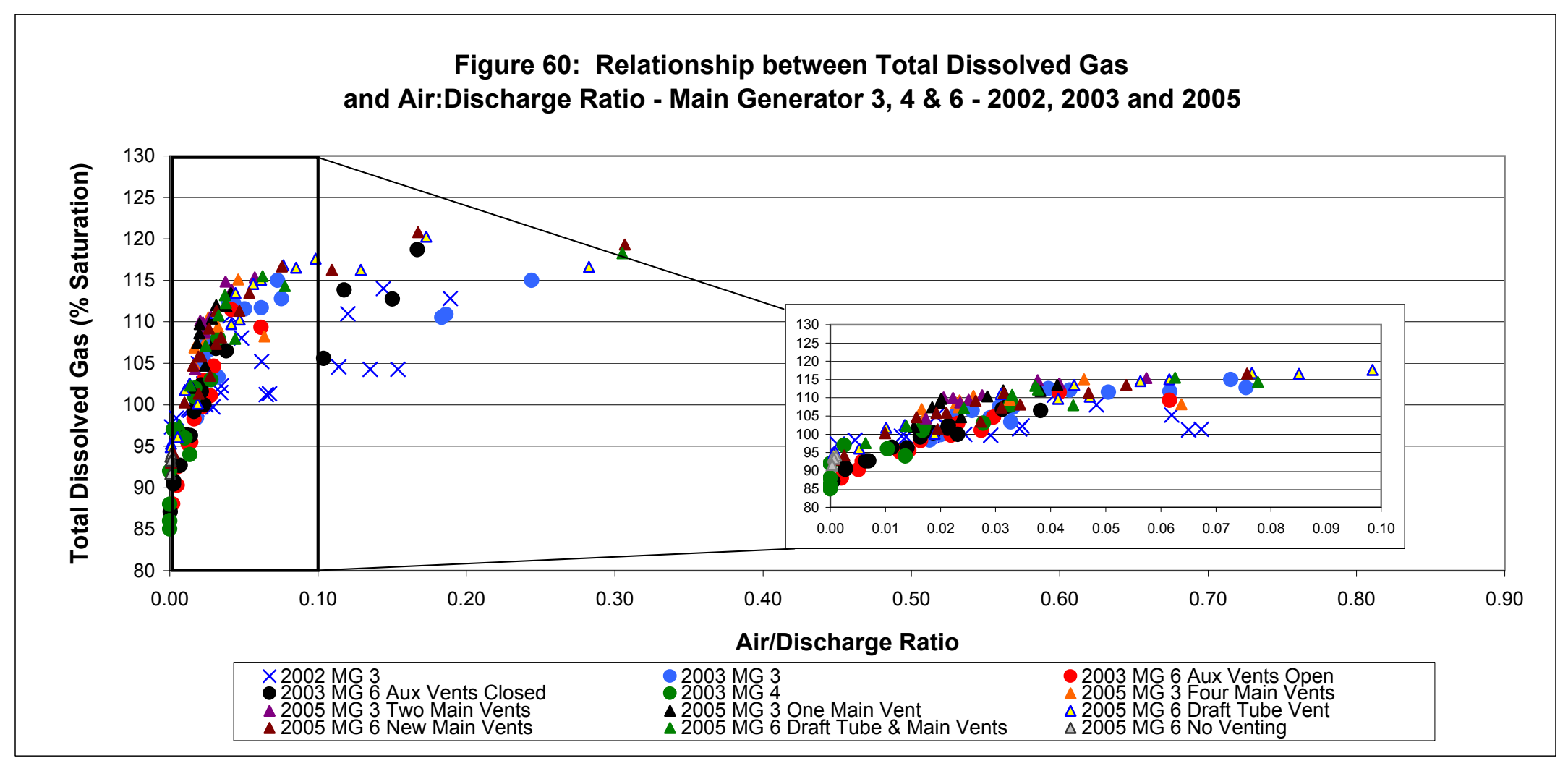




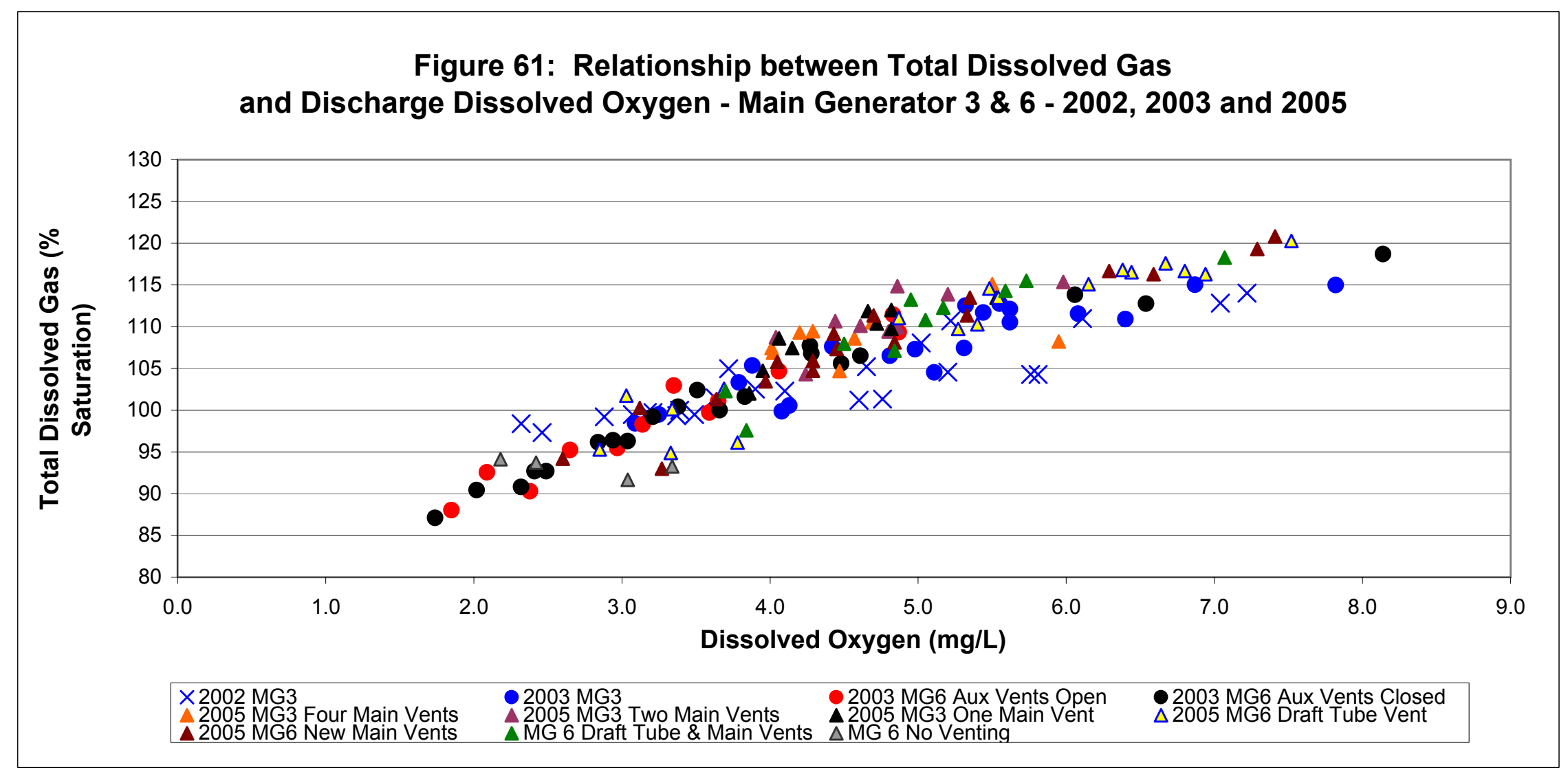

Discharge Dissolved Oxygen that which was measured in the discharge boil of the study unit. 


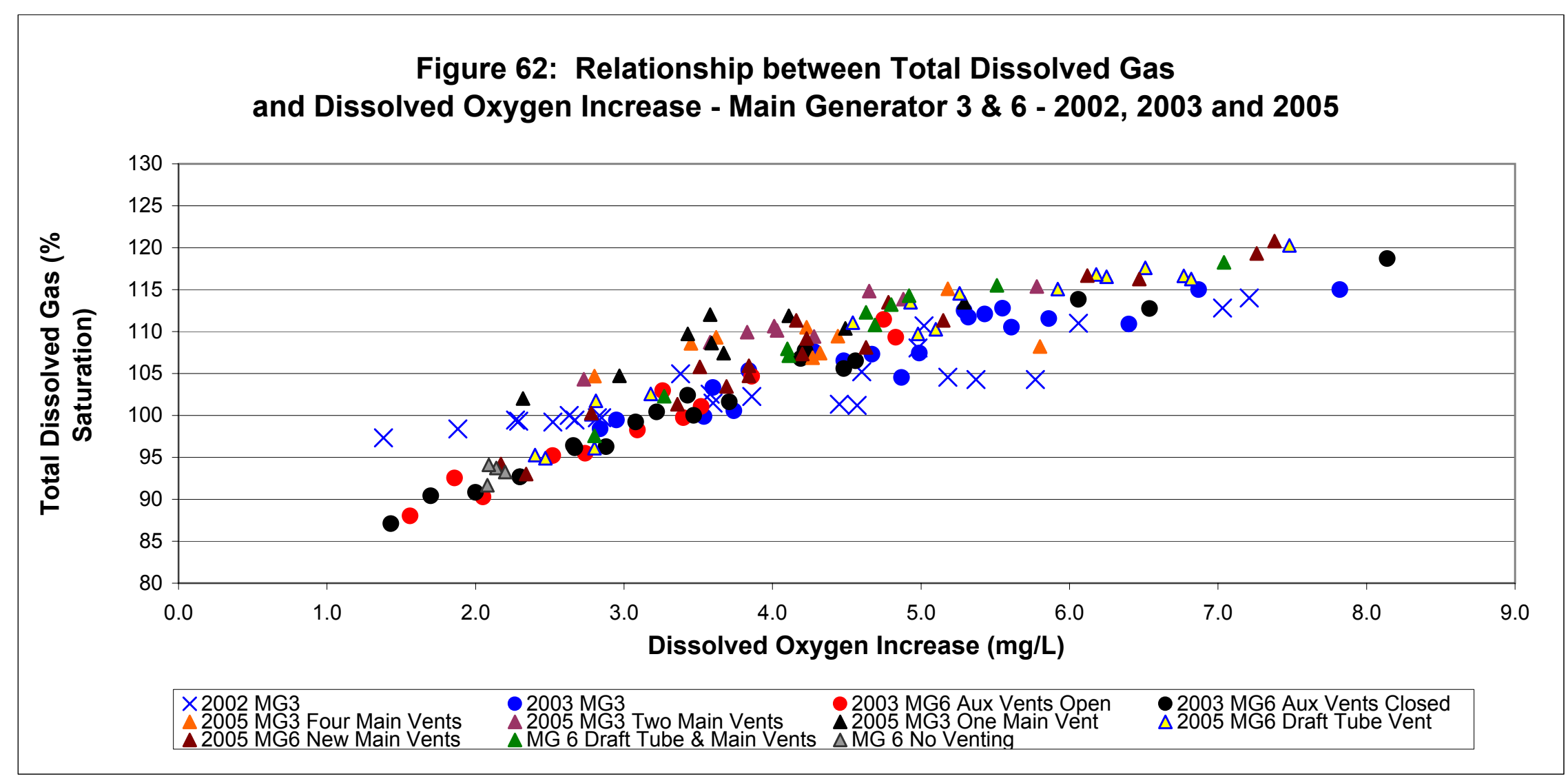

Dissolved Oxgyen Increase is the difference between the study unit discharge dissolved oxygen and the study unit intake dissolved oxygen. 
APPENDIX 2 
Table 1: 2002 Main Generator 3 Data

\begin{tabular}{|c|c|c|c|c|c|c|c|c|c|c|c|c|c|}
\hline \multicolumn{14}{|c|}{ Measured Values } \\
\hline \multirow[b]{2}{*}{ Run \# } & \multirow[b]{2}{*}{$\begin{array}{c}\text { Aux Vents } \\
\text { Unit } 6\end{array}$} & \multirow{2}{*}{$\begin{array}{c}\text { Gate } \\
\text { Setting } \\
\%\end{array}$} & \multirow{2}{*}{$\begin{array}{c}\text { Tailrace } \\
\text { Elev. } \\
\text { (feet) }\end{array}$} & \multirow{2}{*}{$\begin{array}{c}\text { Barometric } \\
\text { Pressure } \\
\text { mmHg }\end{array}$} & \multicolumn{7}{|c|}{ Barrel 3 Air Flow Data } & \multirow[b]{2}{*}{$\begin{array}{c}\text { Discharge } \\
\text { (cfs) }\end{array}$} & \multirow{2}{*}{$\begin{array}{c}\text { Tailrace } \\
\text { Water Temp } \\
\left({ }^{\circ} \mathrm{C}\right)\end{array}$} \\
\hline & & & & & $\begin{array}{l}\text { Air Temp } \\
\left({ }^{\circ} \mathrm{C}\right)\end{array}$ & $\begin{array}{c}\text { Vent } 1 \\
\text { (cfm) }\end{array}$ & $\begin{array}{c}\text { Vent } 2 \\
\text { (cfm) }\end{array}$ & $\begin{array}{c}\text { Vent } 3 \\
\text { (cfm) }\end{array}$ & $\begin{array}{l}\text { Vent } 4 \\
\text { (cfm) }\end{array}$ & $\begin{array}{l}\text { Total } \\
\text { (cfm) }\end{array}$ & $\begin{array}{l}\text { Stndrd } \\
\text { (scfm) }\end{array}$ & & \\
\hline $1 \mathrm{a}$ & Closed & $1 \mathrm{MW}$ & 551.52 & 749 & 29 & 5,100 & 4,600 & 4,633 & 5,045 & 6,475 & 6,090 & 537 & 23.6 \\
\hline $1 a$ & Closed & $1 \mathrm{MW}$ & 551.52 & & & & & & & & & 537 & \\
\hline $2 a$ & Open & $2 \mathrm{MW}$ & 551.61 & 749 & 29 & 5,340 & 4,860 & 4,873 & 5,491 & 6,986 & 6,570 & 760 & 23.5 \\
\hline $2 a$ & Open & $2 \mathrm{MW}$ & 551.61 & & & & & & & & & 760 & \\
\hline $7 a$ & Closed & $1 \mathrm{MW}$ & 553.57 & 748 & 29 & 4,216 & 3,932 & 4,028 & 4,645 & 5,703 & 5,360 & 581 & 24.4 \\
\hline $8 a$ & Closed & $2 \mathrm{MW}$ & 554.18 & 747 & 29 & 4,326 & 4,044 & 4,147 & 4,702 & 5,843 & 5,480 & 760 & 24.3 \\
\hline $9 a$ & Closed & $40 \%$ & 554.18 & 747 & 30 & 5,472 & 5,011 & 4,977 & 5,550 & 7,111 & 6,650 & 1,788 & 24.5 \\
\hline $10 \mathrm{~b}$ & Open & $60 \%$ & 554.09 & 748 & 30 & 5,548 & 5,089 & 5,041 & 5,573 & 7,213 & 6,760 & 2,772 & 24.7 \\
\hline $11 a$ & Closed & $80 \%$ & 554.26 & 747 & 31 & 4,330 & 4,140 & 4,185 & 4,888 & 5,797 & 5,400 & 3,909 & 24.9 \\
\hline $12 a$ & Closed & $90 \%$ & 554.44 & 747 & 31 & 4,068 & 3,838 & 3,891 & 4,623 & 5,599 & 5,220 & 4,527 & 25.0 \\
\hline $13 a$ & Closed & $1 \mathrm{MW}$ & 557.06 & 746 & 32 & 3,271 & 3,074 & 3,213 & 4,225 & 4,671 & 4,340 & 535 & 24.4 \\
\hline $14 a$ & Closed & $2 \mathrm{MW}$ & 557.00 & 746 & 32 & 3,526 & 3,261 & 3,380 & 4,382 & 4,924 & 4,570 & 669 & 24.4 \\
\hline $15 a$ & Closed & $40 \%$ & 556.97 & 746 & 32 & 4,147 & 3,798 & 3,866 & 4,661 & 5,567 & 5,170 & 1,784 & 24.6 \\
\hline $16 \mathrm{~b}$ & Open & $60 \%$ & 556.94 & 747 & 31 & 4,645 & 4,229 & 4,275 & 4,965 & 6,176 & 5,760 & 2,760 & 24.8 \\
\hline $17 a$ & Closed & $80 \%$ & 557.02 & 746 & 31 & 3,806 & 3,612 & 3,662 & 4,424 & 5,227 & 4,870 & 3,883 & 24.9 \\
\hline $18 a$ & Closed & $90 \%$ & 557.07 & 745 & 32 & 2,300 & 2,445 & 2,556 & 3,753 & 3,747 & 3,470 & 4,486 & 25.1 \\
\hline $19 a$ & Closed & $1 \mathrm{MW}$ & 559.82 & 746 & 32 & 576 & 1,942 & 2,096 & 2,752 & 2,497 & 2,320 & 574 & 24.6 \\
\hline $20 a$ & Closed & $2 \mathrm{MW}$ & 559.98 & 746 & 32 & 1,709 & 2,059 & 2,186 & 3,392 & 3,158 & 2,930 & 751 & 24.5 \\
\hline $21 a$ & Closed & $40 \%$ & 560.12 & 746 & 33 & 2,497 & 2,573 & 2,732 & 3,800 & 3,938 & 3,640 & 1,767 & 24.9 \\
\hline $22 a$ & Closed & $60 \%$ & 560.10 & 746 & 33 & 3,770 & 3,616 & 3,644 & 4,368 & 5,180 & 4,790 & 2,745 & 25.0 \\
\hline $23 a$ & Closed & $80 \%$ & 560.09 & 746 & 33 & 2,889 & 2,922 & 2,992 & 3,814 & 4,257 & 3,940 & 3,885 & 25.1 \\
\hline $24 a$ & Closed & $90 \%$ & 560.14 & 746 & 33 & 130 & 782 & 1,313 & 1,632 & 1,308 & 1,210 & 4,481 & 25.1 \\
\hline $27 a$ & Closed & $40 \%$ & 562.75 & 746 & 33 & 906 & 1,232 & 1,440 & 2,414 & 2,055 & 1,900 & 1,755 & 25.7 \\
\hline $28 a$ & Closed & $60 \%$ & 562.93 & 746 & 34 & 3,134 & 2,982 & 2,989 & 3,765 & 4,362 & 4,020 & 2,745 & 25.9 \\
\hline $29 a$ & Closed & $80 \%$ & 563.04 & 746 & 34 & 2,216 & 2,343 & 2,450 & 3,380 & 3,470 & 3,200 & 3,879 & 25.9 \\
\hline $30 a$ & Closed & $90 \%$ & 563.20 & 746 & 34 & 31 & 27 & 20 & 1,015 & 371 & 340 & 4,478 & 25.9 \\
\hline
\end{tabular}


Table 1 continued: 2002 Main Generator 3 Data

\begin{tabular}{|c|c|c|c|c|c|c|c|c|c|c|c|c|}
\hline \multicolumn{13}{|c|}{ Measured Values } \\
\hline Run \# & $\begin{array}{c}\text { Aux Vents } \\
\text { Unit } 6\end{array}$ & $\begin{array}{c}\text { Gate } \\
\text { Setting } \\
\%\end{array}$ & $\begin{array}{c}\text { Tailrace } \\
\text { Elev. } \\
\text { (feet) }\end{array}$ & $\begin{array}{c}\text { TDG } \\
\text { mmHg }\end{array}$ & TDG \% & $\begin{array}{c}\text { Calculated } \\
\text { TDG \% }\end{array}$ & $\begin{array}{c}\text { Calculated } \\
\text { PT-PO2 }\end{array}$ & $\begin{array}{c}\text { \% Sat } \\
\text { Nitrogen } \\
+ \text { Aragon }\end{array}$ & $\begin{array}{c}\text { Tailrace } \\
\text { DO } \\
\text { mg/L }\end{array}$ & $\begin{array}{c}\text { Tailrace } \\
\text { DO } \\
\% \text { Sat }\end{array}$ & $\begin{array}{c}\text { Intake } \\
\text { DO } \\
\mathrm{mg} / \mathrm{L}\end{array}$ & $\begin{array}{c}\text { Datasheet } \\
\text { DO } \\
\mathrm{mg} / \mathrm{L}\end{array}$ \\
\hline $1 a$ & Closed & $1 \mathrm{MW}$ & 551.52 & 845 & 113 & 112.8 & 716 & 125 & 7.04 & 84.4 & 0.01 & 6.90 \\
\hline $1 a$ & Closed & $1 \mathrm{MW}$ & 551.52 & & & & & & 7.07 & & & 6.90 \\
\hline $2 a$ & Open & $2 \mathrm{MW}$ & 551.61 & 854 & 114 & 114.0 & 722 & 126 & 7.22 & 86.4 & 0.01 & 7.10 \\
\hline $2 a$ & Open & $2 \mathrm{MW}$ & 551.61 & & & & & & 7.50 & & & 7.20 \\
\hline $7 a$ & Closed & $1 \mathrm{MW}$ & 553.57 & 780 & 104 & 104.3 & 673 & 117 & 5.76 & 70.2 & 0.39 & 5.75 \\
\hline $8 a$ & Closed & $2 \mathrm{MW}$ & 554.18 & 829 & 111 & 111.0 & 716 & 125 & 6.11 & 74.5 & 0.05 & 5.97 \\
\hline $9 a$ & Closed & $40 \%$ & 554.18 & 786 & 105 & 105.2 & 700 & 122 & 4.65 & 56.9 & 0.05 & 4.58 \\
\hline $10 \mathrm{~b}$ & Open & $60 \%$ & 554.09 & 828 & 111 & 110.7 & 731 & 128 & 5.22 & 64.0 & 0.20 & 5.04 \\
\hline $11 a$ & Closed & $80 \%$ & 554.26 & 766 & 103 & 102.5 & 693 & 121 & 3.90 & 48.1 & 0.32 & 3.84 \\
\hline $12 a$ & Closed & $90 \%$ & 554.44 & 784 & 105 & 105.0 & 714 & 125 & 3.72 & 45.9 & 0.34 & 3.61 \\
\hline $13 a$ & Closed & $1 \mathrm{MW}$ & 557.06 & 778 & 104 & 104.3 & 670 & 117 & 5.81 & 71.0 & 0.04 & 5.84 \\
\hline $14 a$ & Closed & $2 \mathrm{MW}$ & 557.00 & 780 & 105 & 104.6 & 684 & 120 & 5.20 & 63.6 & 0.02 & 5.16 \\
\hline $15 a$ & Closed & $40 \%$ & 556.97 & 806 & 108 & 108.0 & 713 & 125 & 5.02 & 61.6 & 0.04 & 4.73 \\
\hline $16 \mathrm{~b}$ & Open & $60 \%$ & 556.94 & 764 & 102 & 102.3 & 688 & 120 & 4.10 & 50.4 & 0.24 & 3.99 \\
\hline $17 a$ & Closed & $80 \%$ & 557.02 & 744 & 100 & 99.7 & 685 & 120 & 3.17 & 39.1 & 0.35 & 3.14 \\
\hline $18 a$ & Closed & $90 \%$ & 557.07 & 741 & 99 & 99.5 & 683 & 120 & 3.07 & 38.1 & 0.40 & 2.87 \\
\hline $19 a$ & Closed & $1 \mathrm{MW}$ & 559.82 & 756 & 101 & 101.3 & 668 & 117 & 4.76 & 58.4 & 0.31 & 4.74 \\
\hline $20 a$ & Closed & $2 \mathrm{MW}$ & 559.98 & 755 & 101 & 101.2 & 670 & 117 & 4.60 & 56.4 & 0.03 & 4.64 \\
\hline $21 a$ & Closed & $40 \%$ & 560.12 & 757 & 101 & 101.5 & 689 & 121 & 3.63 & 44.8 & 0.03 & 3.64 \\
\hline $22 a$ & Closed & $60 \%$ & 560.10 & 744 & 100 & 99.7 & 684 & 120 & 3.21 & 39.7 & 0.36 & 3.14 \\
\hline $23 a$ & Closed & $80 \%$ & 560.09 & 740 & 99 & 99.2 & 686 & 120 & 2.88 & 35.7 & 0.36 & 2.77 \\
\hline $24 a$ & Closed & $90 \%$ & 560.14 & 734 & 98 & 98.4 & 691 & 121 & 2.32 & 28.7 & 0.44 & 2.10 \\
\hline $27 a$ & Closed & $40 \%$ & 562.75 & 742 & 99 & 99.5 & 676 & 119 & 3.49 & 43.7 & 1.22 & 3.30 \\
\hline $28 a$ & Closed & $60 \%$ & 562.93 & 746 & 100 & 100.0 & 682 & 120 & 3.39 & 42.6 & 0.76 & 3.61 \\
\hline $29 a$ & Closed & $80 \%$ & 563.04 & 741 & 99 & 99.3 & 677 & 119 & 3.37 & 42.4 & 1.08 & 3.19 \\
\hline $30 a$ & Closed & $90 \%$ & 563.20 & 726 & 97 & 97.3 & 679 & 119 & 2.46 & 30.9 & 1.08 & 2.36 \\
\hline
\end{tabular}


Table 1 continued: 2002 Main Generator 3 Data

\begin{tabular}{|c|c|c|c|c|c|c|c|c|c|c|c|}
\hline \multicolumn{12}{|c|}{ Calculated Values } \\
\hline Run \# & $\begin{array}{c}\text { Aux Vents } \\
\text { Unit } 6\end{array}$ & $\begin{array}{c}\text { Gate } \\
\text { Setting } \\
\%\end{array}$ & $\begin{array}{c}\text { Tailrace } \\
\text { Elev. } \\
\text { (feet) }\end{array}$ & $\begin{array}{c}\text { Net DO } \\
\text { Transfer } \\
\text { mg/L }\end{array}$ & $\begin{array}{c}\mathrm{O} 2 \text { in Water } \\
\mathrm{lb} . / \mathrm{min}\end{array}$ & $\begin{array}{c}\mathrm{O} 2 \text { in Air }{ }^{1} \\
\text { lb./min }\end{array}$ & $\begin{array}{c}\text { Air Flowl } \\
\text { Discharge } \\
\end{array}$ & $\begin{array}{c}\text { Oxygen } \\
\text { Transfer } \\
\text { Efficiency } \\
\end{array}$ & $\begin{array}{l}\text { Aeration } \\
\text { Efficiency }\end{array}$ & $\begin{array}{c}\text { Oxygen } \\
\text { Transfer } \\
\text { Rate (Ib/hr) }\end{array}$ & $\begin{array}{c}\text { Predicted } \\
\text { OTE }\end{array}$ \\
\hline $1 \mathrm{a}$ & Closed & $1 \mathrm{MW}$ & 551.52 & 7.03 & 11.6 & 93.6 & 0.231 & $12 \%$ & 0.818 & 700 & $12 \%$ \\
\hline $1 \mathrm{a}$ & Closed & $1 \mathrm{MW}$ & 551.52 & & & & & & & & \\
\hline $2 a$ & Open & $2 \mathrm{MW}$ & 551.61 & 7.21 & 18.4 & 101.0 & 0.161 & $18 \%$ & 0.839 & 1,100 & $15 \%$ \\
\hline $2 a$ & Open & $2 \mathrm{MW}$ & 551.61 & & & & & & & & \\
\hline $7 a$ & Closed & $1 \mathrm{MW}$ & 553.57 & 5.37 & 10.1 & 82.4 & 0.179 & $12 \%$ & 0.670 & 600 & $14 \%$ \\
\hline $8 a$ & Closed & $2 \mathrm{MW}$ & 554.18 & 6.06 & 14.8 & 84.2 & 0.141 & $18 \%$ & 0.726 & 890 & $17 \%$ \\
\hline $9 a$ & Closed & $40 \%$ & 554.18 & 4.60 & 29.6 & 102.0 & 0.064 & $29 \%$ & 0.551 & 1,780 & $28 \%$ \\
\hline $10 \mathrm{~b}$ & Open & $60 \%$ & 554.09 & 5.02 & 51.7 & 103.6 & 0.041 & $50 \%$ & 0.612 & 3,100 & $38 \%$ \\
\hline $11 a$ & Closed & $80 \%$ & 554.26 & 3.58 & 55.1 & 82.5 & 0.022 & $67 \%$ & 0.443 & 3,310 & $59 \%$ \\
\hline $12 a$ & Closed & $90 \%$ & 554.44 & 3.38 & 62.0 & 79.8 & 0.018 & $78 \%$ & 0.419 & 3,720 & $68 \%$ \\
\hline $13 a$ & Closed & $1 \mathrm{MW}$ & 557.06 & 5.77 & 9.9 & 66.1 & 0.157 & $15 \%$ & 0.690 & 600 & $15 \%$ \\
\hline $14 a$ & Closed & $2 \mathrm{MW}$ & 557.00 & 5.18 & 11.8 & 69.6 & 0.125 & $17 \%$ & 0.618 & 710 & $18 \%$ \\
\hline $15 a$ & Closed & $40 \%$ & 556.97 & 4.98 & 32.3 & 78.7 & 0.050 & $41 \%$ & 0.596 & 1,940 & $34 \%$ \\
\hline $16 \mathrm{~b}$ & Open & $60 \%$ & 556.94 & 3.86 & 40.0 & 88.0 & 0.035 & $46 \%$ & 0.473 & 2,400 & $43 \%$ \\
\hline $17 a$ & Closed & $80 \%$ & 557.02 & 2.82 & 43.5 & 74.4 & 0.020 & $58 \%$ & 0.350 & 2,610 & $63 \%$ \\
\hline $18 a$ & Closed & $90 \%$ & 557.07 & 2.67 & 49.1 & 52.8 & 0.012 & $93 \%$ & 0.338 & 2,950 & $89 \%$ \\
\hline $19 a$ & Closed & $1 \mathrm{MW}$ & 559.82 & 4.45 & 8.2 & 35.3 & 0.079 & $23 \%$ & 0.550 & 490 & $25 \%$ \\
\hline $20 a$ & Closed & $2 \mathrm{MW}$ & 559.98 & 4.57 & 11.3 & 44.6 & 0.074 & $25 \%$ & 0.546 & 680 & $26 \%$ \\
\hline $21 a$ & Closed & $40 \%$ & 560.12 & 3.60 & 23.3 & 55.2 & 0.035 & $42 \%$ & 0.430 & 1,400 & $43 \%$ \\
\hline $22 a$ & Closed & $60 \%$ & 560.10 & 2.85 & 29.6 & 72.7 & 0.029 & $41 \%$ & 0.354 & 1,770 & $49 \%$ \\
\hline $23 a$ & Closed & $80 \%$ & 560.09 & 2.52 & 38.8 & 59.8 & 0.016 & $65 \%$ & 0.317 & 2,330 & $73 \%$ \\
\hline $24 a$ & Closed & $90 \%$ & 560.14 & 1.88 & 34.3 & 18.4 & 0.004 & $187 \%$ & 0.239 & 2,060 & $182 \%$ \\
\hline $27 a$ & Closed & $40 \%$ & 562.75 & 2.27 & 14.1 & 28.8 & 0.019 & $49 \%$ & 0.321 & 850 & $64 \%$ \\
\hline $28 a$ & Closed & $60 \%$ & 562.93 & 2.63 & 27.2 & 60.8 & 0.024 & $45 \%$ & 0.349 & 1,630 & $55 \%$ \\
\hline $29 a$ & Closed & $80 \%$ & 563.04 & 2.29 & 35.2 & 48.4 & 0.013 & $73 \%$ & 0.317 & 2,110 & $84 \%$ \\
\hline $30 a$ & Closed & $90 \%$ & 563.20 & 1.38 & 25.0 & 5.1 & 0.001 & $487 \%$ & 0.191 & 1,500 & \\
\hline
\end{tabular}


Table 2: 2002 Main Generator 6 Data - Auxiliary Vents Open

\begin{tabular}{|c|c|c|c|c|c|c|c|c|c|c|c|c|}
\hline \multicolumn{13}{|c|}{ Measured Values } \\
\hline Run \# & $\begin{array}{c}\text { Gate } \\
\text { Setting } \\
\%\end{array}$ & $\begin{array}{c}\text { Tailrace } \\
\text { Elev. } \\
\text { (feet) }\end{array}$ & $\begin{array}{c}\text { Baro Press. } \\
\text { (mmHg) }\end{array}$ & $\begin{array}{c}\text { Air Temp } \\
\left({ }^{\circ} \mathrm{C}\right)\end{array}$ & $\begin{array}{c}\text { Air Flow } \\
\text { (cfm) }\end{array}$ & $\begin{array}{l}\text { Std Air Flow } \\
\text { (scfm) }\end{array}$ & $\begin{array}{c}\text { Discharge } \\
\text { (cfs) }\end{array}$ & $\begin{array}{c}\text { Tailrace } \\
\text { Water Temp } \\
\left({ }^{\circ} \mathrm{C}\right)\end{array}$ & $\begin{array}{c}\text { Tailrace } \\
\text { DO } \\
\text { mg/L }\end{array}$ & $\begin{array}{c}\text { Tailrace } \\
\text { DO } \\
\% \text { Sat }\end{array}$ & $\begin{array}{c}\text { Intake } \\
\text { DO } \\
\mathrm{mg} / \mathrm{L}\end{array}$ & $\begin{array}{c}\text { Datasheet } \\
\text { DO } \\
\mathrm{mg} / \mathrm{L}\end{array}$ \\
\hline $1 \mathrm{~b}$ & $1 \mathrm{MW}$ & 551.54 & 745 & 28 & 8,514 & 8,000 & 450 & 23.6 & 7.26 & 87.6 & 0.12 & 7.20 \\
\hline $2 b$ & $2 \mathrm{MW}$ & 551.57 & 747 & 28 & 8,856 & 8,340 & 614 & 23.7 & 7.18 & 86.5 & 0.12 & 7.10 \\
\hline $7 b$ & $1 \mathrm{MW}$ & 553.66 & 746 & 28 & 6,322 & 5,950 & 491 & 24.4 & 5.82 & 71.2 & 0.14 & 5.70 \\
\hline $8 b$ & $2 \mathrm{MW}$ & 554.05 & 747 & 28 & 6,569 & 6,190 & 614 & 24.2 & 6.13 & 74.6 & 0.14 & 5.90 \\
\hline $9 b$ & $40 \%$ & 554.09 & 747 & 28 & 5,741 & 5,410 & 1,758 & 24.5 & 4.54 & 55.5 & 0.22 & 4.50 \\
\hline $10 \mathrm{~b}$ & $60 \%$ & 554.09 & 747 & 28 & 4,868 & 4,580 & 2,779 & 24.7 & 3.76 & 46.2 & 0.24 & 3.60 \\
\hline $11 \mathrm{~b}$ & $80 \%$ & 554.47 & 746 & 28 & 1,748 & 1,640 & 3,947 & 24.9 & 2.38 & 29.4 & 0.32 & 2.40 \\
\hline $13 b$ & $1 \mathrm{MW}$ & 557.04 & 746 & 30 & 5,259 & 4,910 & 540 & 24.5 & 4.32 & 52.9 & 0.12 & 4.30 \\
\hline $14 b$ & $2 \mathrm{MW}$ & 557.00 & 745 & 30 & 5,644 & 5,270 & 675 & 24.4 & 5.06 & 62.0 & 0.12 & 5.00 \\
\hline $15 b$ & $40 \%$ & 556.94 & 745 & 30 & 4,267 & 3,980 & 1,800 & 24.6 & 4.22 & 51.9 & 0.24 & 4.00 \\
\hline $16 \mathrm{~b}$ & $60 \%$ & 556.94 & 746 & 30 & 3,408 & 3,180 & 2,796 & 24.8 & 3.55 & 43.7 & 0.24 & 3.50 \\
\hline $17 \mathrm{~b}$ & $80 \%$ & 557.03 & 745 & 30 & 469 & 440 & 3,929 & 25.0 & 2.02 & 25.0 & 0.37 & 1.90 \\
\hline $18 b$ & $90 \%$ & 557.06 & 744 & 30 & 20 & 20 & 4,333 & 25.0 & 1.93 & 23.9 & 0.38 & 1.80 \\
\hline $19 b$ & $1 \mathrm{MW}$ & 559.87 & 745 & 30 & 4,786 & 4,470 & 582 & 24.8 & 5.39 & 66.5 & 0.51 & 5.00 \\
\hline $20 b$ & $2 \mathrm{MW}$ & 559.95 & 745 & 30 & 5,567 & 5,190 & 717 & 25.0 & 3.67 & 45.4 & 0.15 & 3.50 \\
\hline $21 b$ & $40 \%$ & 560.17 & 745 & 30 & 2,920 & 2,720 & 1,792 & 25.1 & 3.94 & 48.9 & 0.23 & 3.80 \\
\hline $22 b$ & $60 \%$ & 560.08 & 745 & 30 & 2,577 & 2,400 & 2,780 & 25.3 & 3.13 & 39.0 & 0.23 & 2.90 \\
\hline $23 b$ & $80 \%$ & 560.11 & 745 & 30 & 268 & 250 & 3,867 & 25.5 & 2.01 & 25.1 & 0.54 & 1.90 \\
\hline $24 b$ & $90 \%$ & 560.11 & 745 & 30 & 0 & 0 & 4,242 & 25.5 & 2.06 & 25.7 & 0.54 & 1.90 \\
\hline $27 b$ & $40 \%$ & 562.75 & 747 & 31 & 1,541 & 1,440 & 1,765 & 25.8 & 3.52 & 44.1 & 0.65 & 3.40 \\
\hline $28 b$ & $60 \%$ & 562.78 & 746 & 31 & 1,330 & 1,240 & 2,747 & 26.0 & 3.43 & 43.2 & 0.65 & 3.40 \\
\hline $29 b$ & $80 \%$ & 563.03 & 745 & 31 & 125 & 120 & 3,795 & 26.2 & 2.57 & 32.5 & 0.92 & 2.50 \\
\hline $30 b$ & $90 \%$ & 563.13 & 745 & 31 & 0 & 0 & 4,155 & 26.1 & 2.54 & 32.1 & 0.92 & 2.40 \\
\hline
\end{tabular}


Table 2 continued: 2002 Main Generator 6 Data - Auxiliary Vents Open

\begin{tabular}{|c|c|c|c|c|c|c|c|c|c|c|}
\hline \multicolumn{11}{|c|}{ Calculated Values } \\
\hline Run \# & $\begin{array}{c}\text { Gate } \\
\text { Setting } \\
\%\end{array}$ & $\begin{array}{c}\text { Tailrace } \\
\text { Elev. } \\
\text { (feet) }\end{array}$ & $\begin{array}{l}\text { Net DO } \\
\text { transfer } \\
\mathrm{mg} / \mathrm{L}\end{array}$ & $\begin{array}{c}\text { O2 in Water } \\
\text { lb./min }\end{array}$ & $\begin{array}{c}\mathrm{O} 2 \mathrm{in} \text { Air }{ }^{1} \\
\text { lb./min }\end{array}$ & $\begin{array}{l}\text { Air Flowl } \\
\text { Discharge }\end{array}$ & $\begin{array}{c}\text { Oxygen } \\
\text { Transfer } \\
\text { Efficiency }\end{array}$ & $\begin{array}{l}\text { Aeration } \\
\text { Efficiency }\end{array}$ & $\begin{array}{c}\text { Oxygen } \\
\text { Transfer } \\
\text { Rate (lb/hr) }\end{array}$ & $\begin{array}{l}\text { Predicted } \\
\text { OTE }\end{array}$ \\
\hline $1 \mathrm{~b}$ & $1 \mathrm{MW}$ & 551.54 & 7.14 & 12.0 & 125.8 & 0.296 & $10 \%$ & 0.842 & 720 & $8 \%$ \\
\hline $2 b$ & $2 \mathrm{MW}$ & 551.57 & 7.06 & 16.4 & 131.1 & 0.224 & $13 \%$ & 0.833 & 980 & $10 \%$ \\
\hline $7 \mathrm{~b}$ & $1 \mathrm{MW}$ & 553.66 & 5.68 & 10.4 & 93.6 & 0.202 & $11 \%$ & 0.688 & 630 & $10 \%$ \\
\hline $8 b$ & 2MW & 554.05 & 5.99 & 13.9 & 97.3 & 0.166 & $14 \%$ & 0.725 & 830 & $12 \%$ \\
\hline $9 b$ & $40 \%$ & 554.09 & 4.32 & 29.8 & 85.1 & 0.049 & $35 \%$ & 0.528 & 1,790 & $32 \%$ \\
\hline $10 \mathrm{~b}$ & $60 \%$ & 554.09 & 3.52 & 39.8 & 72.0 & 0.025 & $55 \%$ & 0.431 & 2,390 & $55 \%$ \\
\hline $11 b$ & $80 \%$ & 554.47 & 2.06 & 31.2 & 25.8 & 0.007 & $121 \%$ & 0.255 & 1,870 & $157 \%$ \\
\hline $13 b$ & $1 \mathrm{MW}$ & 557.04 & 4.20 & 7.6 & 77.2 & 0.170 & $10 \%$ & 0.507 & 450 & $12 \%$ \\
\hline $14 b$ & $2 \mathrm{MW}$ & 557.00 & 4.94 & 11.3 & 82.9 & 0.144 & $14 \%$ & 0.597 & 680 & $14 \%$ \\
\hline $15 b$ & $40 \%$ & 556.94 & 3.98 & 27.1 & 62.6 & 0.036 & $43 \%$ & 0.488 & 1,630 & $41 \%$ \\
\hline $16 b$ & $60 \%$ & 556.94 & 3.31 & 36.8 & 50.0 & 0.018 & $74 \%$ & 0.406 & 2,210 & $72 \%$ \\
\hline $17 \mathrm{~b}$ & $80 \%$ & 557.03 & 1.65 & 24.7 & 6.9 & 0.002 & $356 \%$ & 0.205 & 1,480 & $442 \%$ \\
\hline $18 b$ & $90 \%$ & 557.06 & 1.55 & 25.3 & 0.3 & 0.000 & $8030 \%$ & 0.196 & 1,520 & $5558 \%$ \\
\hline $19 b$ & $1 \mathrm{MW}$ & 559.87 & 4.88 & 9.5 & 70.3 & 0.143 & $14 \%$ & 0.619 & 570 & $14 \%$ \\
\hline $20 b$ & $2 \mathrm{MW}$ & 559.95 & 3.52 & 9.2 & 81.6 & 0.124 & $11 \%$ & 0.427 & 550 & $15 \%$ \\
\hline $21 b$ & $40 \%$ & 560.17 & 3.71 & 24.9 & 42.8 & 0.025 & $58 \%$ & 0.460 & 1,490 & $55 \%$ \\
\hline $22 b$ & $60 \%$ & 560.08 & 2.90 & 31.7 & 37.7 & 0.014 & $84 \%$ & 0.359 & 1,900 & $89 \%$ \\
\hline $23 b$ & $80 \%$ & 560.11 & 1.47 & 21.6 & 3.9 & 0.001 & $550 \%$ & 0.189 & 1,300 & $686 \%$ \\
\hline $24 b$ & $90 \%$ & 560.11 & 1.52 & 24.4 & 0.0 & 0.000 & & 0.196 & 1,470 & \\
\hline $27 b$ & $40 \%$ & 562.75 & 2.87 & 18.9 & 22.6 & 0.014 & $84 \%$ & 0.375 & 1,140 & $90 \%$ \\
\hline $28 b$ & $60 \%$ & 562.78 & 2.78 & 29.9 & 19.5 & 0.007 & $153 \%$ & 0.373 & 1,790 & $149 \%$ \\
\hline $29 b$ & $80 \%$ & 563.03 & 1.65 & 24.0 & 1.9 & 0.001 & $1271 \%$ & 0.230 & 1,440 & $1218 \%$ \\
\hline $30 b$ & $90 \%$ & 563.13 & 1.62 & 25.7 & 0.0 & 0.000 & & 0.226 & 1,540 & \\
\hline
\end{tabular}


Table 3: 2002 Main Generator 6 Data - Auxiliary Vents Closed

\begin{tabular}{|c|c|c|c|c|c|c|c|c|c|c|c|c|}
\hline \multicolumn{13}{|c|}{ Measured Values } \\
\hline Run \# & $\begin{array}{c}\text { Gate } \\
\text { Setting } \\
\%\end{array}$ & $\begin{array}{c}\text { Tailrace } \\
\text { Elev. } \\
\text { (feet) }\end{array}$ & $\begin{array}{c}\text { Baro Press. } \\
(\mathrm{mmHg})\end{array}$ & $\begin{array}{l}\text { Air Temp } \\
\left({ }^{\circ} \mathrm{C}\right)\end{array}$ & $\begin{array}{l}\text { Air Flow } \\
\text { (cfm) }\end{array}$ & $\begin{array}{l}\text { Std Air Flow } \\
\text { (scfm) }\end{array}$ & $\begin{array}{l}\text { Discharge } \\
\text { (cfs) }\end{array}$ & $\begin{array}{c}\text { Tailrace } \\
\text { Water Temp } \\
\left({ }^{\circ} \mathrm{C}\right)\end{array}$ & $\begin{array}{c}\text { Tailrace } \\
\text { DO } \\
\text { mg/L }\end{array}$ & $\begin{array}{c}\text { Tailrace } \\
\text { DO } \\
\% \text { Sat }\end{array}$ & $\begin{array}{l}\text { Intake } \\
\text { DO } \\
\mathrm{mg} / \mathrm{L}\end{array}$ & $\begin{array}{c}\text { Datasheet } \\
\text { DO } \\
\mathrm{mg} / \mathrm{L}\end{array}$ \\
\hline $1 \mathrm{a}$ & $1 \mathrm{MW}$ & 551.54 & 745 & 28 & 4,234 & 3,980 & 450 & 23.7 & 6.82 & 82.4 & 0.12 & 6.80 \\
\hline $2 a$ & $2 \mathrm{MW}$ & 551.57 & 749 & 28 & 4,252 & 4,020 & 614 & 23.7 & 6.86 & 82.4 & 0.12 & 6.90 \\
\hline $7 a$ & $1 \mathrm{MW}$ & 553.66 & 747 & 28 & 4,282 & 4,030 & 491 & 24.5 & 4.86 & 59.5 & 0.17 & 4.70 \\
\hline $8 a$ & $2 \mathrm{MW}$ & 554.05 & 746 & 28 & 4,300 & 4,040 & 614 & 24.2 & 5.77 & 70.3 & 0.14 & 5.70 \\
\hline $9 a$ & $40 \%$ & 554.09 & 746 & 28 & 3,040 & 2,860 & 1,758 & 24.4 & 4.21 & 51.5 & 0.22 & 4.00 \\
\hline $10 a$ & $60 \%$ & 554.09 & 746 & 28 & 2,890 & 2,720 & 2,779 & 24.7 & 3.37 & 41.4 & 0.24 & 3.40 \\
\hline $11 \mathrm{a}$ & $80 \%$ & 554.47 & 746 & 28 & 1,093 & 1,030 & 3,947 & 24.9 & 2.23 & 27.5 & 0.24 & 2.15 \\
\hline $13 a$ & $1 \mathrm{MW}$ & 557.04 & 746 & 31 & 3,202 & 2,980 & 540 & 24.5 & 4.41 & 54.0 & 0.12 & 4.30 \\
\hline $14 a$ & $2 \mathrm{MW}$ & 557.00 & 745 & 30 & 3,578 & 3,340 & 675 & 24.5 & 4.20 & 51.5 & 0.12 & 4.20 \\
\hline $15 a$ & $40 \%$ & 556.94 & 745 & 30 & 2,206 & 2,060 & 1,800 & 24.7 & 3.90 & 48.0 & 0.12 & 3.70 \\
\hline $16 a$ & $60 \%$ & 556.94 & 746 & 30 & 2,701 & 2,520 & 2,796 & 24.8 & 3.11 & 38.3 & 0.33 & 2.80 \\
\hline $17 a$ & $80 \%$ & 557.03 & 745 & 30 & 0 & 0 & 3,929 & 25.0 & 2.08 & 25.8 & 0.37 & 1.90 \\
\hline $18 a$ & $90 \%$ & 557.06 & 744 & 30 & 0 & 0 & 4,333 & 25.0 & 1.99 & 24.7 & 0.38 & 1.90 \\
\hline $19 a$ & $1 \mathrm{MW}$ & 559.87 & 744 & 30 & 3,370 & 3,140 & 582 & 24.8 & 4.60 & 56.8 & 0.51 & 4.60 \\
\hline $20 a$ & $2 \mathrm{MW}$ & 559.95 & 745 & 30 & 3,504 & 3,270 & 761 & 24.9 & 3.94 & 48.7 & 0.17 & 3.70 \\
\hline $21 a$ & $40 \%$ & 560.17 & 745 & 30 & 2,865 & 2,670 & 1,792 & 25.2 & 3.01 & 37.4 & 0.23 & 2.80 \\
\hline $22 a$ & $60 \%$ & 560.08 & 746 & 30 & 2,115 & 1,980 & 2,780 & 25.3 & 3.05 & 37.9 & 0.46 & 2.80 \\
\hline $23 a$ & $80 \%$ & 560.11 & 745 & 30 & 0 & 0 & 3,867 & 25.4 & 1.97 & 24.6 & 0.46 & 1.90 \\
\hline $24 a$ & $90 \%$ & 560.11 & 745 & 30 & 0 & 0 & 4,242 & 25.6 & 2.02 & 25.3 & 0.54 & 1.90 \\
\hline $27 a$ & $40 \%$ & 562.75 & 746 & 31 & 1,700 & 1,580 & 1,765 & 25.8 & 3.61 & 45.3 & 1.01 & 3.50 \\
\hline $28 a$ & $60 \%$ & 562.78 & 746 & 31 & 1,615 & 1,500 & 2,747 & 26.0 & 3.28 & 41.3 & 0.65 & 3.10 \\
\hline $29 a$ & $80 \%$ & 563.03 & 746 & 31 & 0 & 0 & 3,795 & 26.1 & 2.79 & 35.2 & 0.65 & 2.60 \\
\hline $30 a$ & $90 \%$ & 563.13 & 745 & 31 & 0 & 0 & 4,155 & 26.1 & 2.40 & 30.3 & 0.92 & 2.40 \\
\hline
\end{tabular}


Table 3 continued: 2002 Main Generator 6 Data - Auxiliary Vents Closed

\begin{tabular}{|c|c|c|c|c|c|c|c|c|c|}
\hline \multicolumn{10}{|c|}{ Calculated Values } \\
\hline Run \# & $\begin{array}{c}\text { Gate } \\
\text { Setting } \\
\%\end{array}$ & $\begin{array}{c}\text { Tailrace } \\
\text { Elev. } \\
\text { (feet) }\end{array}$ & $\begin{array}{c}\text { Net DO } \\
\text { transfer } \\
\mathrm{mg} / \mathrm{L}\end{array}$ & $\begin{array}{c}02 \text { in Water } \\
\text { lb./min }\end{array}$ & $\begin{array}{c}\mathrm{O} 2 \text { in Air }{ }^{1} \\
\text { lb./min }\end{array}$ & $\begin{array}{l}\text { Air Flow/ } \\
\text { Discharge }\end{array}$ & $\begin{array}{l}\text { Oxygen } \\
\text { Transfer } \\
\text { Efficiency }\end{array}$ & $\begin{array}{l}\text { Aeration } \\
\text { Efficiency }\end{array}$ & $\begin{array}{c}\text { Oxygen } \\
\text { Transfer } \\
\text { Rate (lb/hr) }\end{array}$ \\
\hline $1 \mathrm{a}$ & $1 \mathrm{MW}$ & 551.54 & 6.70 & 11.3 & 62.6 & 0.147 & $18 \%$ & 0.790 & 680 \\
\hline $2 a$ & $2 \mathrm{MW}$ & 551.57 & 6.74 & 15.7 & 63.2 & 0.108 & $25 \%$ & 0.795 & 940 \\
\hline $7 a$ & $1 \mathrm{MW}$ & 553.66 & 4.69 & 8.6 & 63.4 & 0.137 & $14 \%$ & 0.570 & 520 \\
\hline $8 a$ & $2 \mathrm{MW}$ & 554.05 & 5.63 & 13.1 & 63.5 & 0.109 & $21 \%$ & 0.682 & 780 \\
\hline $9 a$ & $40 \%$ & 554.09 & 3.99 & 27.5 & 45.0 & 0.026 & $61 \%$ & 0.488 & 1,650 \\
\hline $10 \mathrm{a}$ & $60 \%$ & 554.09 & 3.13 & 35.4 & 42.8 & 0.015 & $83 \%$ & 0.384 & 2,120 \\
\hline $11 a$ & $80 \%$ & 554.47 & 1.99 & 30.1 & 16.2 & 0.004 & $186 \%$ & 0.244 & 1,810 \\
\hline $13 a$ & $1 \mathrm{MW}$ & 557.04 & 4.29 & 7.7 & 46.9 & 0.103 & $16 \%$ & 0.518 & 460 \\
\hline $14 a$ & $2 \mathrm{MW}$ & 557.00 & 4.08 & 9.3 & 52.5 & 0.091 & $18 \%$ & 0.493 & 560 \\
\hline $15 a$ & $40 \%$ & 556.94 & 3.78 & 25.8 & 32.4 & 0.019 & $80 \%$ & 0.457 & 1,550 \\
\hline $16 a$ & $60 \%$ & 556.94 & 2.78 & 30.9 & 39.6 & 0.014 & $78 \%$ & 0.344 & 1,860 \\
\hline $17 a$ & $80 \%$ & 557.03 & 1.71 & 25.6 & 0.0 & 0.000 & & 0.213 & 1,530 \\
\hline $18 a$ & $90 \%$ & 557.06 & 1.61 & 26.2 & 0.0 & 0.000 & & 0.203 & 1,570 \\
\hline $19 a$ & $1 \mathrm{MW}$ & 559.87 & 4.09 & 8.0 & 49.4 & 0.101 & $16 \%$ & 0.518 & 480 \\
\hline $20 a$ & $2 \mathrm{MW}$ & 559.95 & 3.77 & 9.9 & 51.4 & 0.078 & $19 \%$ & 0.458 & 590 \\
\hline $21 a$ & $40 \%$ & 560.17 & 2.78 & 18.6 & 42.0 & 0.025 & $44 \%$ & 0.344 & 1,120 \\
\hline $22 a$ & $60 \%$ & 560.08 & 2.59 & 28.3 & 31.1 & 0.011 & $91 \%$ & 0.330 & 1,700 \\
\hline $23 a$ & $80 \%$ & 560.11 & 1.51 & 22.2 & 0.0 & 0.000 & & 0.193 & 1,330 \\
\hline $24 a$ & $90 \%$ & 560.11 & 1.48 & 23.8 & 0.0 & 0.000 & & 0.191 & 1,430 \\
\hline $27 a$ & $40 \%$ & 562.75 & 2.60 & 17.1 & 24.8 & 0.015 & $69 \%$ & 0.357 & 1,030 \\
\hline $28 a$ & $60 \%$ & 562.78 & 2.63 & 28.3 & 23.6 & 0.009 & $120 \%$ & 0.353 & 1,700 \\
\hline $29 a$ & $80 \%$ & 563.03 & 2.14 & 31.1 & 0.0 & 0.000 & & 0.287 & 1,870 \\
\hline $30 a$ & $90 \%$ & 563.13 & 1.48 & 23.4 & 0.0 & 0.000 & & 0.206 & 1,410 \\
\hline
\end{tabular}


Table 4: 2003 Main Generator 3 Data

\begin{tabular}{|c|c|c|c|c|c|c|c|c|c|c|c|c|c|}
\hline \multicolumn{14}{|c|}{ Measured Values } \\
\hline Run \# & $\begin{array}{c}\text { Gate } \\
\text { Setting } \\
\%\end{array}$ & $\begin{array}{l}\text { Unit } \\
\text { Load } \\
\text { MW }\end{array}$ & $\begin{array}{c}\text { Tailrace } \\
\text { Elev. } \\
\text { (feet) }\end{array}$ & $\begin{array}{c}\text { Baro Press. } \\
(\mathrm{mmHg})\end{array}$ & $\begin{array}{c}\text { Tailrace } \\
\text { Air Temp } \\
\left({ }^{\circ} \mathrm{C}\right)\end{array}$ & $\begin{array}{c}\text { Relative } \\
\text { Humidity } \\
\%\end{array}$ & $\begin{array}{c}\text { Turbine Barrel } \\
\text { Air Temp } \\
\left({ }^{\circ} \mathrm{C}\right)\end{array}$ & $\begin{array}{c}\text { Air Flow } \\
\text { (cfs) }\end{array}$ & $\begin{array}{c}\text { Standard } \\
\text { Air Flow } \\
\text { (scfm) }\end{array}$ & $\begin{array}{c}\text { Discharge } \\
\text { (cfs) }\end{array}$ & $\begin{array}{c}\text { Tailrace } \\
\text { Water Temp } \\
\left({ }^{\circ} \mathrm{C}\right)\end{array}$ & $\begin{array}{c}\text { Rounded } \\
\text { Water Temp } \\
\left({ }^{\circ} \mathrm{C}\right)\end{array}$ & $\begin{array}{c}\text { Tailrace } \\
\text { Sp. Cond. } \\
\text { uS/cm }\end{array}$ \\
\hline 1 & $11 \%$ & 1 & 551.63 & 754 & 19 & 63 & 26 & 128 & 7,200 & 492 & 18.3 & 18.3 & 312 \\
\hline 2 & $12 \%$ & 1 & 554.16 & 753 & 26 & 55 & 28 & 110 & 6,000 & 537 & 19.2 & 19.2 & 312 \\
\hline 3 & $40 \%$ & 10 & 553.93 & 753 & 26 & 54 & 28 & 139 & 7,800 & 1,788 & 19.2 & 19.2 & 312 \\
\hline 4 & $60 \%$ & 16 & 554.09 & 753 & 26 & 53 & 28 & 145 & 8,400 & 2,772 & 19.4 & 19.4 & 313 \\
\hline 6 & $90 \%$ & 31 & 554.31 & 753 & 27 & 54 & 29 & 159 & 9,000 & 4,527 & 20.1 & 20.1 & 312 \\
\hline 7 & $11 \%$ & 1 & 556.60 & 752 & 32 & 45 & 32 & 96 & 5,400 & 490 & 19.6 & 19.6 & 312 \\
\hline 8 & $40 \%$ & 9 & 556.83 & 752 & 33 & 45 & 32 & 115 & 6,600 & 1,784 & 19.6 & 19.6 & 312 \\
\hline 9 & $40 \%$ & 9 & 557.01 & 752 & 34 & 47 & & & & 1,784 & & & \\
\hline 10 & $60 \%$ & 16 & 557.03 & 752 & 37 & 41 & & & & 2,760 & & & \\
\hline 11 & $60 \%$ & 16 & 556.94 & 752 & 37 & 44 & 35 & 125 & 7,200 & 2,760 & 20.0 & 20.0 & 311 \\
\hline 12 & $80 \%$ & 24 & 556.97 & 752 & 36 & 45 & 35 & 107 & 6,000 & 3,883 & 20.3 & 20.3 & 310 \\
\hline 13 & $18 \%$ & 3 & 557.23 & 752 & 37 & 44 & & & & & & & \\
\hline 14 & Float & 0 & 557.14 & 752 & 37 & 45 & & & & & & & \\
\hline 16 & $12 \%$ & 1 & 559.88 & 752 & 36 & 43 & 36 & 42 & 2,400 & 530 & 19.8 & 19.8 & 312 \\
\hline 17 & $40 \%$ & 9 & 560.02 & 751 & 35 & 48 & 36 & 76 & 4,200 & 1,767 & 20.0 & 20.0 & 312 \\
\hline 18 & $40 \%$ & 7 & 560.20 & 751 & 34 & 46 & & & & 1,767 & & & \\
\hline 19 & $40 \%$ & 7 & 560.22 & 751 & 33 & 45 & & & & 1,767 & & & \\
\hline 20 & $60 \%$ & 16 & 560.22 & 752 & 31 & 48 & 32 & 96 & 5,400 & 2,745 & 20.1 & 20.1 & 312 \\
\hline 21 & $80 \%$ & 24 & 560.21 & 752 & 30 & 49 & 32 & 89 & 4,800 & 3,885 & 20.7 & 20.7 & 311 \\
\hline 22 & $80 \%$ & 29 & 560.21 & 752 & 31 & 49 & & & & 3,885 & & & \\
\hline 23 & $80 \%$ & 30 & 560.33 & 751 & 33 & 46 & & & & 3,885 & & & \\
\hline 24 & $90 \%$ & 30 & 560.30 & 751 & 33 & 46 & 33 & 98 & 5,400 & 4,481 & 21.3 & 21.3 & 310 \\
\hline 25 & $40 \%$ & 7 & 562.83 & 751 & 34 & 48 & 26 & 41 & 2,400 & 1,755 & 20.5 & 20.5 & 312 \\
\hline 26 & $40 \%$ & 6 & 562.91 & 751 & 33 & 48 & & & & 1,755 & & & \\
\hline 27 & $40 \%$ & 6 & 563.00 & 751 & 31 & 50 & & & & 1,755 & & & \\
\hline 28 & $60 \%$ & 15 & 563.18 & 751 & 32 & 49 & 27 & 78 & 4,200 & 2,745 & 20.3 & 20.3 & 312 \\
\hline 29 & $80 \%$ & 24 & 563.30 & 751 & 32 & 49 & 26 & 75 & 4,200 & 3,879 & 20.8 & 20.8 & 311 \\
\hline 30 & $67 \%$ & 20 & 563.43 & 751 & 31 & 50 & & & & & & & \\
\hline 31 & $55 \%$ & 13 & 563.15 & 751 & 31 & 50 & & & & 2,479 & & & \\
\hline 32 & $90 \%$ & 30 & 563.09 & 751 & 31 & 50 & 26 & 88 & 4,800 & 4,478 & 20.7 & 20.7 & 311 \\
\hline
\end{tabular}


Table 4 continued: 2003 Main Generator 3 Data

\begin{tabular}{|c|c|c|c|c|c|c|c|c|c|c|c|c|c|}
\hline \multicolumn{14}{|c|}{ Measured Values } \\
\hline Run \# & $\begin{array}{c}\text { Gate } \\
\text { Setting } \\
\%\end{array}$ & $\begin{array}{l}\text { Unit } \\
\text { Load } \\
\text { MW }\end{array}$ & $\begin{array}{c}\text { Tailrace } \\
\text { Elev. } \\
\text { (feet) }\end{array}$ & $\begin{array}{c}\text { TDG } \\
\mathrm{mmHg}\end{array}$ & $\begin{array}{c}\text { Measured } \\
\text { TDG } \\
\text { \% Sat }\end{array}$ & $\begin{array}{c}\text { Calculated } \\
\text { TDG } \\
\% \text { Sat }\end{array}$ & $\begin{array}{c}\text { Recorded } \\
\text { PT-pO2 } \\
\text { mmHg }\end{array}$ & $\begin{array}{c}\text { Calculated } \\
\mathrm{P}_{\mathrm{T}}-\mathrm{pO}_{2} \\
\mathrm{mmHg}\end{array}$ & $\begin{array}{c}\text { Calculated } \\
\% \text { Sat } \\
\mathrm{NO}_{2}+\mathrm{Ar}\end{array}$ & $\begin{array}{c}\text { Tailrace } \\
\text { DO } \\
\text { mg/L }\end{array}$ & $\begin{array}{c}\text { Recorded } \\
\text { Tailrace DO } \\
\% \text { Sat }\end{array}$ & $\begin{array}{c}\text { Calculated } \\
\text { Tailrace DO } \\
\% \text { Sat }\end{array}$ & $\begin{array}{c}\text { Intake } \\
\text { DO } \\
\text { mg/L }\end{array}$ \\
\hline 1 & $11 \%$ & 1 & 551.63 & 867 & 115 & 115.0 & 717 & 737 & 126 & 7.82 & 83.1 & 83.9 & 0.00 \\
\hline 2 & $12 \%$ & 1 & 554.16 & 835 & 110 & 110.9 & 711 & 727 & 125 & 6.40 & 69.2 & 70.0 & 0.00 \\
\hline 3 & $40 \%$ & 10 & 553.93 & 866 & 115 & 115.0 & & 750 & 129 & 6.87 & & & 0.00 \\
\hline 4 & $60 \%$ & 16 & 554.09 & 840 & 111 & 111.6 & 719 & 737 & 128 & 6.08 & 66.2 & 66.8 & 0.22 \\
\hline 5 & $80 \%$ & 24 & 554.25 & 809 & 107 & 107.4 & 700 & 718 & 124 & 5.31 & 58.3 & 58.9 & 0.32 \\
\hline 6 & $90 \%$ & 31 & 554.31 & 808 & 107 & 107.3 & 705 & 723 & 124 & 4.98 & 54.8 & 55.5 & 0.31 \\
\hline 7 & $11 \%$ & 1 & 556.60 & 831 & 110 & 110.5 & 723 & 735 & 127 & 5.62 & 61.4 & 62.1 & 0.01 \\
\hline 8 & $40 \%$ & 9 & 556.83 & 840 & 111 & 111.7 & 731 & 748 & 129 & 5.44 & 59.4 & 60.1 & 0.12 \\
\hline 9 & $40 \%$ & 9 & 557.01 & & & & & & & & & & \\
\hline 10 & $60 \%$ & 16 & 557.03 & & & & & & & & & & \\
\hline 11 & $60 \%$ & 16 & 556.94 & 843 & 112 & 112.1 & 726 & 747 & 129 & 5.62 & 61.9 & 62.6 & 0.19 \\
\hline 12 & $80 \%$ & 24 & 556.97 & 801 & 106 & 106.5 & 699 & 718 & 124 & 4.81 & 53.3 & 53.9 & 0.33 \\
\hline 13 & $18 \%$ & 3 & 557.23 & & & & & & & & & & \\
\hline 14 & Float & 0 & 557.14 & & & & & & & & & & \\
\hline 15 & $90 \%$ & 31 & 557.14 & 786 & 104 & 104.5 & 681 & 698 & 120 & 5.11 & 56.6 & 57.4 & 0.24 \\
\hline 16 & $12 \%$ & 1 & 559.88 & 848 & 112 & 112.8 & 747 & 753 & 130 & 5.55 & 60.9 & 61.6 & 0.00 \\
\hline 17 & $40 \%$ & 9 & 560.02 & 845 & 112 & 112.5 & 754 & 754 & 130 & 5.32 & 58.5 & 59.3 & 0.03 \\
\hline 18 & $40 \%$ & 7 & 560.20 & & & & & & & & & & \\
\hline 19 & $40 \%$ & 7 & 560.22 & & & & & & & & & & \\
\hline 20 & $60 \%$ & 16 & 560.22 & 777 & 103 & 103.3 & 712 & 712 & 123 & 3.79 & 41.9 & 42.3 & 0.19 \\
\hline 21 & $80 \%$ & 24 & 560.21 & 756 & 100 & 100.5 & 681 & 684 & 118 & 4.13 & 46.1 & 46.6 & 0.39 \\
\hline 22 & $80 \%$ & 29 & 560.21 & & & & & & & & & & \\
\hline 23 & $80 \%$ & 30 & 560.33 & & & & & & & & & & \\
\hline 24 & $90 \%$ & 30 & 560.30 & 750 & 99 & 99.9 & 680 & 678 & 117 & 4.08 & 46.2 & 46.7 & 0.54 \\
\hline 25 & $40 \%$ & 7 & 562.83 & 791 & 105 & 105.3 & 726 & 724 & 125 & 3.88 & 43.1 & 43.7 & 0.04 \\
\hline 26 & $40 \%$ & 6 & 562.91 & & & & & & & & & & \\
\hline 27 & $40 \%$ & 6 & 563.00 & & & & & & & & & & \\
\hline 28 & $60 \%$ & 15 & 563.18 & 808 & 107 & 107.6 & 740 & 732 & 126 & 4.42 & 48.9 & 49.6 & 0.14 \\
\hline 29 & $80 \%$ & 24 & 563.30 & 739 & 98 & 98.4 & 678 & 685 & 118 & 3.09 & 34.6 & 35.0 & 0.25 \\
\hline 30 & $67 \%$ & 20 & 563.43 & & & & & & & & & & \\
\hline 31 & $55 \%$ & 13 & 563.15 & & & & & & & & & & \\
\hline 32 & $90 \%$ & 30 & 563.09 & 747 & 99 & 99.5 & 694 & 691 & 119 & 3.25 & 36.3 & 36.8 & 0.30 \\
\hline
\end{tabular}


Table 4 continued: 2003 Main Generator 3 Data

\begin{tabular}{|c|c|c|c|c|c|c|c|c|c|c|c|}
\hline \multicolumn{12}{|c|}{ Calculated Values } \\
\hline Run \# & $\begin{array}{c}\text { Gate } \\
\text { Setting } \\
\%\end{array}$ & $\begin{array}{l}\text { Unit } \\
\text { Load } \\
\text { MW }\end{array}$ & $\begin{array}{c}\text { Tailrace } \\
\text { Elev. } \\
\text { (feet) }\end{array}$ & $\begin{array}{l}\text { Aeration } \\
\text { Efficiency }\end{array}$ & $\begin{array}{c}\text { Net DO } \\
\text { Transfer } \\
\mathrm{mg} / \mathrm{L}\end{array}$ & $\begin{array}{c}\text { O2 in Water } \\
\text { lb./min }\end{array}$ & $\begin{array}{l}\mathrm{O} 2 \text { in Air } \\
\mathrm{lb} . / \mathrm{min}\end{array}$ & $\begin{array}{l}\text { Air Flowl } \\
\text { Discharge }\end{array}$ & $\begin{array}{l}\text { Oxygen } \\
\text { Transfer } \\
\text { Efficiency }\end{array}$ & $\begin{array}{c}\text { Oxygen } \\
\text { Transfer } \\
\text { Rate (lb/hr) }\end{array}$ & $\begin{array}{c}\text { OTR/ } \\
\text { Air Discharge }\end{array}$ \\
\hline 1 & $11 \%$ & 1 & 551.63 & 0.84 & 7.82 & 10.3 & 111.5 & 0.341 & $9 \%$ & 620 & 0.07 \\
\hline 2 & $12 \%$ & 1 & 554.16 & 0.70 & 6.40 & 9.5 & 92.5 & 0.253 & $10 \%$ & 570 & 0.07 \\
\hline 3 & $40 \%$ & 10 & 553.93 & & 6.87 & 43.5 & 120.2 & 0.077 & $36 \%$ & 2,610 & 0.06 \\
\hline 4 & $60 \%$ & 16 & 554.09 & 0.66 & 5.86 & 57.9 & 129.4 & 0.053 & $45 \%$ & 3,470 & 0.05 \\
\hline 5 & $80 \%$ & 24 & 554.25 & 0.57 & 4.99 & 71.0 & 110.7 & 0.032 & $64 \%$ & 4,260 & 0.05 \\
\hline 6 & $90 \%$ & 31 & 554.31 & 0.54 & 4.67 & 79.0 & 138.3 & 0.033 & $57 \%$ & 4,740 & 0.03 \\
\hline 7 & $11 \%$ & 1 & 556.60 & 0.62 & 5.61 & 6.5 & 82.2 & 0.289 & $8 \%$ & 390 & 0.07 \\
\hline 8 & $40 \%$ & 9 & 556.83 & 0.60 & 5.32 & 33.2 & 100.5 & 0.066 & $33 \%$ & 1,990 & 0.05 \\
\hline 9 & $40 \%$ & 9 & 557.01 & & & & & & & & \\
\hline 10 & $60 \%$ & 16 & 557.03 & & & & & & & & \\
\hline 11 & $60 \%$ & 16 & 556.94 & 0.62 & 5.43 & 53.3 & 108.5 & 0.046 & $49 \%$ & 3,200 & 0.05 \\
\hline 12 & $80 \%$ & 24 & 556.97 & 0.52 & 4.48 & 63.5 & 90.4 & 0.026 & $70 \%$ & 3,810 & 0.05 \\
\hline 13 & $18 \%$ & 3 & 557.23 & & & & & & & & \\
\hline 14 & Float & 0 & 557.14 & & & & & & & & \\
\hline 15 & $90 \%$ & 31 & 557.14 & 0.56 & 4.87 & 82.5 & 116.7 & 0.029 & $71 \%$ & 4,950 & 0.04 \\
\hline 16 & $12 \%$ & 1 & 559.88 & 0.62 & 5.55 & 6.9 & 36.0 & 0.120 & $19 \%$ & 420 & 0.15 \\
\hline 17 & $40 \%$ & 9 & 560.02 & 0.59 & 5.29 & 33.1 & 63.1 & 0.042 & $52 \%$ & 1,980 & 0.08 \\
\hline 18 & $40 \%$ & 7 & 560.20 & & & & & & & & \\
\hline 19 & $40 \%$ & 7 & 560.22 & & & & & & & & \\
\hline 20 & $60 \%$ & 16 & 560.22 & 0.41 & 3.60 & 35.4 & 82.2 & 0.034 & $43 \%$ & 2,120 & 0.04 \\
\hline 21 & $80 \%$ & 24 & 560.21 & 0.44 & 3.74 & 53.2 & 73.1 & 0.021 & $73 \%$ & 3,190 & 0.05 \\
\hline 22 & $80 \%$ & 29 & 560.21 & & & & & & & & \\
\hline 23 & $80 \%$ & 30 & 560.33 & & & & & & & & \\
\hline 24 & $90 \%$ & 30 & 560.30 & 0.43 & 3.54 & 59.6 & 81.9 & 0.020 & $73 \%$ & 3,580 & 0.04 \\
\hline 25 & $40 \%$ & 7 & 562.83 & 0.43 & 3.84 & 22.7 & 37.2 & 0.025 & $61 \%$ & 1,360 & 0.10 \\
\hline 26 & $40 \%$ & 6 & 562.91 & & & & & & & & \\
\hline 27 & $40 \%$ & 6 & 563.00 & & & & & & & & \\
\hline 28 & $60 \%$ & 15 & 563.18 & 0.49 & 4.28 & 41.7 & 64.9 & 0.027 & $64 \%$ & 2,500 & 0.07 \\
\hline 29 & $80 \%$ & 24 & 563.30 & 0.33 & 2.84 & 40.3 & 65.1 & 0.018 & $62 \%$ & 2,420 & 0.04 \\
\hline 30 & $67 \%$ & 20 & 563.43 & & & & & & & & \\
\hline 31 & $55 \%$ & 13 & 563.15 & & & & & & & & \\
\hline 32 & $90 \%$ & 30 & 563.09 & 0.35 & 2.95 & 49.4 & 74.3 & 0.018 & $67 \%$ & 2,970 & 0.04 \\
\hline
\end{tabular}


Table 5: 2003 Main Generator 6 Data

\begin{tabular}{|c|c|c|c|c|c|c|c|c|c|c|c|c|c|c|}
\hline \multicolumn{15}{|c|}{ Measured Values } \\
\hline Run \# & $\begin{array}{c}\text { Gate } \\
\text { Setting } \\
\%\end{array}$ & $\begin{array}{l}\text { Unit } \\
\text { Load } \\
\text { MW }\end{array}$ & $\begin{array}{c}\text { Aux } \\
\text { Vents }\end{array}$ & $\begin{array}{c}\text { Tailrace } \\
\text { Elev. } \\
\text { (feet) }\end{array}$ & $\begin{array}{c}\text { Baro Press. } \\
(\mathrm{mmHg})\end{array}$ & $\begin{array}{c}\text { Tailrace } \\
\text { Air Temp } \\
\left({ }^{\circ} \mathrm{C}\right)\end{array}$ & $\begin{array}{c}\text { Relative } \\
\text { Humidity } \\
\%\end{array}$ & $\begin{array}{c}\text { Turbine Barrel } \\
\text { Air Temp } \\
\left({ }^{\circ} \mathrm{C}\right)\end{array}$ & $\begin{array}{c}\text { Air Flow } \\
\text { (cfs) }\end{array}$ & $\begin{array}{c}\text { Standard } \\
\text { Air Flow } \\
\text { (scfm) }\end{array}$ & $\begin{array}{l}\text { Discharge } \\
\text { (cfs) }\end{array}$ & $\begin{array}{c}\text { Tailrace } \\
\text { Water Temp } \\
\left({ }^{\circ} \mathrm{C}\right)\end{array}$ & $\begin{array}{c}\text { Rounded } \\
\text { Water Temp } \\
\left({ }^{\circ} \mathrm{C}\right)\end{array}$ & $\begin{array}{l}\text { Tailrace } \\
\text { Sp. Cond. } \\
\text { uS/cm }\end{array}$ \\
\hline 1 & $12 \%$ & 1 & Closed & 551.63 & 754 & 20 & 54 & 25 & 5,125 & 4,920 & 491 & 18.0 & 18.0 & 305 \\
\hline 2 & $12 \%$ & 1 & Closed & 554.16 & 753 & & 41 & 27 & 4,636 & 4,420 & 491 & $\begin{array}{l}19.3 \\
\end{array}$ & $\begin{array}{l}19.3 \\
\end{array}$ & 306 \\
\hline 3 & $40 \%$ & 11 & Closed & 553.93 & 753 & & 39 & 27 & 4,232 & 4,030 & 1,758 & 19.2 & 19.2 & 303 \\
\hline 4 & $60 \%$ & 20 & Closed & 554.09 & 753 & & 40 & 27 & 3,736 & 3,560 & 2,779 & 19.5 & 19.5 & 302 \\
\hline 5 & $80 \%$ & 29 & Closed & 554.25 & 753 & & 40 & 27 & 3,465 & 3,300 & 3,947 & 20.0 & 20.0 & 303 \\
\hline 6 & $60 \%$ & 20 & Closed & 554.31 & 753 & & 39 & 27 & 4,057 & 3,860 & 2,779 & $\begin{array}{l}19.7 \\
\end{array}$ & $\begin{array}{l}19.7 \\
\end{array}$ & 302 \\
\hline 7 & $12 \%$ & 1 & Closed & 556.60 & 752 & & 52 & 29 & 4,031 & 3,810 & 540 & 19.4 & 19.4 & 302 \\
\hline 8 & $40 \%$ & 11 & Closed & 556.83 & 752 & & 40 & 30 & 3,691 & 3,480 & 1,800 & 19.6 & 19.6 & 304 \\
\hline 9 & $40 \%$ & 11 & Open & 557.01 & 752 & & 38 & 33 & 7,134 & 6,650 & 1,800 & 19.4 & 19.4 & 303 \\
\hline 10 & $60 \%$ & 18 & Open & 557.03 & 752 & & 40 & 33 & 5,331 & 4,970 & 2,796 & 19.7 & 19.7 & 303 \\
\hline 11 & $60 \%$ & 19 & Closed & 556.94 & 752 & & 44 & 33 & 3,364 & 3,140 & 2,796 & $\begin{array}{l}19.7 \\
\end{array}$ & 19.7 & 303 \\
\hline 12 & $80 \%$ & 28 & Closed & 556.97 & 752 & & 51 & 33 & 2,706 & 2,520 & 3,929 & 20.0 & 20.0 & 303 \\
\hline 13 & $80 \%$ & 28 & Open & 557.23 & 752 & & 51 & 34 & 5,563 & 5,170 & 3,929 & 20.1 & 20.1 & 302 \\
\hline 14 & $90 \%$ & 30 & Open & 557.14 & 752 & & 51 & 33 & 3,528 & 3,290 & 4,333 & 20.3 & 20.3 & 302 \\
\hline 15 & $90 \%$ & 30 & Closed & 557.14 & 752 & & 49 & 35 & 1,814 & 1,680 & 4,333 & 20.3 & 20.3 & 302 \\
\hline 16 & $12 \%$ & 1 & Closed & 559.88 & 752 & & 51 & 34 & 3,600 & 3,350 & 537 & 20.4 & 20.4 & 305 \\
\hline 17 & $40 \%$ & 10 & Closed & 560.02 & 751 & & 50 & 33 & 3,609 & 3,360 & 1,792 & 20.3 & 20.3 & 303 \\
\hline 18 & $40 \%$ & 10 & Open & 560.20 & 751 & & 51 & 33 & 4,800 & 4,470 & 1,792 & 20.1 & 20.1 & 303 \\
\hline 19 & $60 \%$ & 18 & Open & 560.22 & 751 & & 51 & 32 & 4,890 & 4,570 & 2,780 & 20.5 & 20.5 & 303 \\
\hline 20 & $60 \%$ & 18 & Closed & 560.22 & 752 & & 51 & 29 & 2,894 & 2,730 & 2,780 & 20.4 & 20.4 & 303 \\
\hline 21 & $80 \%$ & 27 & Closed & 560.21 & 752 & & 52 & 30 & 1,736 & 1,630 & 3,867 & 21.1 & 21.1 & 302 \\
\hline 22 & $80 \%$ & 27 & Open & 560.21 & 752 & & 52 & 30 & 3,514 & 3,310 & 3,867 & 20.9 & 20.9 & 301 \\
\hline 23 & $90 \%$ & 29 & Open & 560.33 & 751 & & & 30 & 1,564 & 1,470 & 4,242 & 20.9 & 20.9 & 302 \\
\hline 24 & $90 \%$ & 28 & Closed & 560.30 & 751 & & 49 & 30 & 733 & 690 & 4,242 & 21.0 & 21.0 & 302 \\
\hline 25 & $40 \%$ & 10 & Closed & 562.83 & 751 & & 49 & 31 & 2,421 & 2,270 & 1,765 & 20.6 & 20.6 & 301 \\
\hline 26 & $40 \%$ & 10 & Open & 562.91 & 751 & & 50 & 31 & 2,613 & 2,450 & 1,765 & 20.3 & 20.3 & 303 \\
\hline 27 & $60 \%$ & 18 & Open & 563.00 & 751 & & 51 & 31 & 2,878 & 2,700 & 2,747 & 20.9 & 20.9 & 301 \\
\hline 28 & $60 \%$ & 18 & Closed & 563.18 & 751 & & 51 & 32 & 1,979 & 1,850 & 2,747 & 21.1 & 21.1 & 301 \\
\hline 29 & $80 \%$ & 26 & Closed & 563.30 & 751 & & 51 & 31 & 656 & 620 & 3,795 & 21.5 & 21.5 & 302 \\
\hline 30 & $80 \%$ & 26 & Open & 563.43 & 751 & & 51 & 31 & 1,248 & 1,170 & 3,795 & 21.4 & 21.4 & 301 \\
\hline 31 & $90 \%$ & 28 & Open & 563.15 & 751 & & 52 & 31 & 544 & 510 & 4,155 & 21.2 & 21.2 & 302 \\
\hline 32 & $90 \%$ & 28 & Closed & 563.09 & 751 & & 51 & 31 & 124 & 120 & 4,155 & 21.2 & 21.2 & 302 \\
\hline
\end{tabular}


Table 5 continued: 2003 Main Generator 6 Data

\begin{tabular}{|c|c|c|c|c|c|c|c|c|c|c|c|c|c|c|}
\hline \multicolumn{15}{|c|}{ Measured Values } \\
\hline Run \# & $\begin{array}{c}\text { Gate } \\
\text { Setting } \\
\%\end{array}$ & $\begin{array}{l}\text { Unit } \\
\text { Load } \\
\text { MW }\end{array}$ & $\begin{array}{c}\text { Aux } \\
\text { Vents }\end{array}$ & $\begin{array}{c}\text { Tailrace } \\
\text { Elev. } \\
\text { (feet) }\end{array}$ & $\begin{array}{c}\text { TDG } \\
\mathrm{mmHg}\end{array}$ & $\begin{array}{c}\text { Measured } \\
\text { TDG } \\
\% \text { Sat }\end{array}$ & $\begin{array}{c}\text { Calculated } \\
\text { TDG } \\
\% \text { Sat }\end{array}$ & $\begin{array}{c}\text { Recorded } \\
\mathrm{P}_{\mathrm{T}-\mathrm{pO} 2} \\
\mathrm{mmHg}\end{array}$ & $\begin{array}{c}\text { Calculated } \\
\mathrm{P}_{\mathrm{T}-\mathrm{pO}_{2}} \\
\mathrm{mmHg}\end{array}$ & $\begin{array}{c}\text { Calculated } \\
\% \text { Sat } \\
\mathrm{NO}_{2}+\mathrm{Ar}\end{array}$ & $\begin{array}{c}\text { Tailrace } \\
\text { DO } \\
\text { mg/L }\end{array}$ & $\begin{array}{c}\text { Recorded } \\
\text { Tailrace Do } \\
\% \text { Sat }\end{array}$ & $\begin{array}{c}\text { Calculated } \\
\text { Tailrace DO } \\
\% \text { Sat }\end{array}$ & $\begin{array}{c}\text { Intake } \\
\text { DO } \\
\mathrm{mg} / \mathrm{L}\end{array}$ \\
\hline 1 & $12 \%$ & 1 & Closed & 551.63 & 895 & 118 & 118.7 & 744 & 761 & 130 & 8.14 & 85.9 & 86.8 & 0.00 \\
\hline 2 & $12 \%$ & 1 & Closed & 554.16 & 849 & 112 & 112.7 & 725 & 738 & 127 & 6.54 & 71.0 & 71.7 & 0.00 \\
\hline 3 & $40 \%$ & 11 & Closed & 553.93 & 802 & 106 & 106.5 & 715 & 724 & 124 & 4.61 & 49.9 & 50.5 & 0.05 \\
\hline 4 & $60 \%$ & 20 & Closed & 554.09 & 765 & 101 & 101.6 & 691 & 700 & 120 & 3.83 & 41.7 & 42.2 & 0.12 \\
\hline 5 & $80 \%$ & 29 & Closed & 554.25 & 725 & 96 & 96.3 & 665 & 673 & 116 & 3.04 & 33.5 & 33.8 & 0.16 \\
\hline 6 & $60 \%$ & 20 & Closed & 554.31 & 753 & 100 & 100.0 & 680 & 691 & 119 & 3.66 & 40.1 & 40.5 & 0.19 \\
\hline 7 & $12 \%$ & 1 & Closed & 556.60 & 856 & 113 & 113.8 & 735 & 753 & 131 & 6.06 & 65.9 & 66.7 & 0.00 \\
\hline 8 & $40 \%$ & 11 & Closed & 556.83 & 810 & 107 & $\begin{array}{l}107.7 \\
\end{array}$ & 720 & 737 & 127 & 4.27 & 46.7 & 47.2 & 0.05 \\
\hline 9 & $40 \%$ & 11 & Open & 557.01 & 822 & 109 & 109.3 & 723 & 740 & 128 & 4.87 & 53.0 & 53.6 & 0.04 \\
\hline 10 & $60 \%$ & 18 & Open & 557.03 & 787 & 104 & 104.7 & & 718 & 124 & 4.06 & 44.4 & 44.9 & 0.20 \\
\hline 11 & $60 \%$ & 19 & Closed & 556.94 & 755 & 100 & 100.4 & 676 & 697 & 120 & 3.38 & 37.0 & 37.4 & 0.16 \\
\hline 12 & $80 \%$ & 28 & Closed & 556.97 & 723 & 95 & 96.1 & 657 & 674 & 116 & 2.84 & 31.3 & 31.6 & 0.17 \\
\hline 13 & $80 \%$ & 28 & Open & 557.23 & 750 & 99 & 99.7 & 671 & 688 & 119 & 3.59 & 39.6 & 40.1 & 0.19 \\
\hline 14 & $90 \%$ & 30 & Open & 557.14 & 716 & 94 & 95.2 & 651 & 670 & 116 & 2.65 & 29.4 & 29.7 & 0.13 \\
\hline 15 & $90 \%$ & 30 & Closed & 557.14 & 697 & 92 & 92.7 & 642 & 655 & 113 & 2.41 & 26.7 & 27.0 & 0.11 \\
\hline 16 & $12 \%$ & 1 & Closed & 559.88 & 794 & 105 & 105.6 & 698 & 717 & 124 & 4.48 & 49.8 & 50.3 & 0.00 \\
\hline 17 & $40 \%$ & 10 & Closed & 560.02 & 802 & 106 & 106.8 & 729 & 728 & 126 & 4.28 & $\begin{array}{l}47.4 \\
\end{array}$ & 48.0 & 0.09 \\
\hline 18 & $40 \%$ & 10 & Open & 560.20 & 837 & 111 & 111.5 & 739 & 754 & 130 & 4.83 & 53.3 & 54.0 & 0.08 \\
\hline 19 & $60 \%$ & 18 & Open & 560.22 & 759 & 100 & 101.1 & 678 & 696 & 120 & 3.65 & 40.5 & 41.1 & 0.13 \\
\hline 20 & $60 \%$ & 18 & Closed & 560.22 & 746 & 99 & 99.2 & 672 & 691 & 119 & 3.21 & 35.7 & 36.0 & 0.13 \\
\hline 21 & $80 \%$ & 27 & Closed & 560.21 & 697 & 92 & 92.7 & 633 & 653 & 113 & 2.49 & 28.2 & 28.3 & 0.19 \\
\hline 22 & $80 \%$ & 27 & Open & 560.21 & 718 & 95 & 95.5 & 649 & 666 & 115 & 2.97 & 33.3 & 33.7 & 0.23 \\
\hline 23 & $90 \%$ & 29 & Open & 560.33 & 695 & 92 & 92.5 & 631 & 659 & 114 & 2.09 & 23.5 & 23.7 & 0.23 \\
\hline 24 & $90 \%$ & 28 & Closed & 560.30 & 679 & 90 & 90.4 & & 644 & 111 & 2.02 & 22.7 & 23.0 & 0.32 \\
\hline 25 & $40 \%$ & 10 & Closed & 562.83 & 769 & 102 & 102.4 & 695 & 708 & 122 & 3.51 & 39.1 & 39.6 & 0.08 \\
\hline 26 & $40 \%$ & 10 & Open & 562.91 & 773 & 102 & 102.9 & 697 & 715 & 123 & 3.35 & 37.1 & 37.6 & 0.09 \\
\hline 27 & $60 \%$ & 18 & Open & 563.00 & 738 & 98 & 98.3 & 664 & 683 & 118 & 3.14 & 35.2 & 35.7 & 0.05 \\
\hline 28 & $60 \%$ & 18 & Closed & 563.18 & 724 & 96 & 96.4 & 652 & 673 & 116 & 2.94 & 33.1 & 33.5 & 0.28 \\
\hline 29 & $80 \%$ & 26 & Closed & 563.30 & 682 & 90 & 90.8 & 622 & 641 & 111 & 2.32 & 26.3 & 26.7 & 0.32 \\
\hline 30 & $80 \%$ & 26 & Open & 563.43 & 678 & 90 & 90.3 & 616 & 636 & 110 & 2.38 & 27.0 & 27.3 & 0.33 \\
\hline 31 & $90 \%$ & 28 & Open & 563.15 & 661 & 87 & 88.0 & 606 & 629 & 109 & 1.85 & 20.9 & 21.1 & 0.29 \\
\hline 32 & $90 \%$ & 28 & Closed & 563.09 & 654 & 86 & 87.1 & 605 & 624 & 108 & 1.74 & 19.7 & 19.9 & 0.31 \\
\hline
\end{tabular}


Table 5 continued: 2003 Main Generator 6 Data

\begin{tabular}{|c|c|c|c|c|c|c|c|c|c|c|c|}
\hline \multicolumn{12}{|c|}{ Calculated Values } \\
\hline Run \# & $\begin{array}{c}\text { Gate } \\
\text { Setting } \\
\%\end{array}$ & $\begin{array}{c}\text { Unit } \\
\text { Load } \\
\text { MW }\end{array}$ & $\begin{array}{c}\text { Aux } \\
\text { Vents }\end{array}$ & $\begin{array}{l}\text { Aeration } \\
\text { Efficiency }\end{array}$ & $\begin{array}{c}\text { Net DO } \\
\text { Transfer } \\
\text { mg/L }\end{array}$ & $\begin{array}{c}\text { O2 in Water } \\
\text { lb./min }\end{array}$ & $\begin{array}{l}\text { O2 in Air } \\
\text { lb./min }\end{array}$ & $\begin{array}{l}\text { Air Flow/ } \\
\text { Discharge }\end{array}$ & $\begin{array}{c}\text { Oxygen } \\
\text { Transfer } \\
\text { Efficiency }\end{array}$ & $\begin{array}{c}\text { Oxygen } \\
\text { Transfer } \\
\text { Rate (lb/hr) }\end{array}$ & $\begin{array}{c}\text { OTR/ } \\
\text { Air Discharge }\end{array}$ \\
\hline 1 & $12 \%$ & 1 & Closed & 0.871 & 8.14 & 17.3 & 76.4 & 0.144 & $23 \%$ & 1,040 & 0.11 \\
\hline 2 & $12 \%$ & 1 & Closed & 0.719 & 6.54 & 13.4 & 68.3 & 0.135 & $20 \%$ & 800 & 0.10 \\
\hline 3 & $40 \%$ & 11 & Closed & 0.503 & 4.56 & 34.0 & 62.3 & 0.034 & $55 \%$ & 2,040 & 0.07 \\
\hline 4 & $60 \%$ & 20 & Closed & 0.416 & 3.71 & 42.3 & 55.0 & 0.020 & $77 \%$ & 2,540 & 0.07 \\
\hline 5 & $80 \%$ & 29 & Closed & 0.328 & 2.88 & 44.9 & 51.0 & 0.013 & $88 \%$ & 2,690 & 0.06 \\
\hline 6 & $60 \%$ & 20 & Closed & 0.394 & 3.47 & 39.5 & 59.6 & 0.021 & $66 \%$ & 2,370 & 0.06 \\
\hline 7 & $12 \%$ & 1 & Closed & 0.667 & 6.06 & 13.0 & 58.6 & 0.111 & $22 \%$ & 780 & 0.10 \\
\hline 8 & $40 \%$ & 11 & Closed & 0.470 & 4.22 & 30.6 & 53.4 & 0.030 & $57 \%$ & 1,830 & 0.08 \\
\hline 9 & $40 \%$ & 11 & Open & 0.535 & 4.83 & 34.7 & 100.9 & 0.058 & $34 \%$ & 2,080 & 0.05 \\
\hline 10 & $60 \%$ & 18 & Open & 0.437 & 3.86 & 42.7 & 75.4 & 0.028 & $57 \%$ & 2,560 & 0.05 \\
\hline 11 & $60 \%$ & 19 & Closed & 0.364 & 3.22 & 36.2 & 47.6 & 0.017 & $76 \%$ & 2,170 & 0.07 \\
\hline 12 & $80 \%$ & 28 & Closed & 0.304 & 2.67 & 41.1 & 38.2 & 0.010 & $107 \%$ & 2,460 & 0.07 \\
\hline 13 & $80 \%$ & 28 & Open & 0.389 & 3.40 & 52.0 & 78.2 & 0.021 & $67 \%$ & 3,120 & 0.04 \\
\hline 14 & $90 \%$ & 30 & Open & 0.287 & 2.52 & 41.5 & 49.9 & 0.012 & $83 \%$ & 2,490 & 0.05 \\
\hline 15 & $90 \%$ & 30 & Closed & 0.262 & 2.30 & 37.9 & 25.3 & 0.006 & $150 \%$ & 2,270 & 0.09 \\
\hline 16 & $12 \%$ & 1 & Closed & 0.505 & 4.48 & 10.2 & 50.7 & 0.092 & $20 \%$ & 610 & 0.09 \\
\hline 17 & $40 \%$ & 10 & Closed & 0.475 & 4.19 & 29.5 & 51.0 & 0.030 & $58 \%$ & 1,770 & 0.08 \\
\hline 18 & $40 \%$ & 10 & Open & 0.536 & 4.75 & 33.4 & 67.8 & 0.040 & $49 \%$ & 2,000 & 0.07 \\
\hline 19 & $60 \%$ & 18 & Open & 0.402 & 3.52 & 38.5 & 69.6 & 0.026 & $55 \%$ & 2,310 & 0.05 \\
\hline 20 & $60 \%$ & 18 & Closed & 0.352 & 3.08 & 33.9 & 42.0 & 0.015 & $81 \%$ & 2,040 & 0.07 \\
\hline 21 & $80 \%$ & 27 & Closed & 0.269 & 2.30 & 34.7 & 25.0 & 0.007 & $139 \%$ & 2,080 & 0.09 \\
\hline 22 & $80 \%$ & 27 & Open & 0.320 & 2.74 & 41.5 & 50.7 & 0.014 & $82 \%$ & 2,490 & 0.05 \\
\hline 23 & $90 \%$ & 29 & Open & 0.217 & 1.86 & 30.4 & 22.5 & 0.006 & $135 \%$ & 1,820 & 0.08 \\
\hline 24 & $90 \%$ & 28 & Closed & 0.201 & 1.70 & 27.6 & 10.6 & 0.003 & $261 \%$ & 1,660 & 0.16 \\
\hline 25 & $40 \%$ & 10 & Closed & 0.392 & 3.43 & 23.6 & 34.7 & 0.021 & $68 \%$ & 1,410 & 0.10 \\
\hline 26 & $40 \%$ & 10 & Open & 0.370 & 3.26 & 22.3 & 37.4 & 0.022 & $60 \%$ & 1,340 & 0.09 \\
\hline 27 & $60 \%$ & 18 & Open & 0.354 & 3.09 & 33.5 & 41.3 & 0.016 & $81 \%$ & 2,010 & 0.07 \\
\hline 28 & $60 \%$ & 18 & Closed & 0.314 & 2.66 & 29.0 & 28.2 & 0.011 & $103 \%$ & 1,740 & 0.09 \\
\hline 29 & $80 \%$ & 26 & Closed & 0.239 & 2.00 & 29.9 & 9.5 & 0.003 & $316 \%$ & 1,800 & 0.21 \\
\hline 30 & $80 \%$ & 26 & Open & 0.245 & 2.05 & 30.6 & 17.9 & 0.005 & $171 \%$ & 1,830 & 0.11 \\
\hline 31 & $90 \%$ & 28 & Open & 0.185 & 1.56 & 25.0 & 7.8 & 0.002 & $321 \%$ & 1,500 & 0.20 \\
\hline 32 & $90 \%$ & 28 & Closed & 0.170 & 1.43 & 23.0 & 1.8 & 0.000 & $1255 \%$ & 1,380 & 0.78 \\
\hline
\end{tabular}


Table 6: 2005 Main Generator 6 Data

\begin{tabular}{|c|c|c|c|c|c|c|c|c|c|c|c|c|c|c|c|c|c|c|c|}
\hline \multicolumn{20}{|c|}{ Measured Values } \\
\hline Run \# & $\begin{array}{c}\text { Gate } \\
\text { Setting } \\
(\%) \\
\end{array}$ & $\begin{array}{l}\text { Unit } \\
\text { Load } \\
\text { (MW) } \\
\end{array}$ & $\begin{array}{l}\text { Draft } \\
\text { Tube } \\
\text { Vents }\end{array}$ & $\begin{array}{l}\text { New } \\
\text { Main } \\
\text { Vents } \\
\end{array}$ & \begin{tabular}{|c} 
Tailrace \\
Elev. \\
(feet) \\
\end{tabular} & \begin{tabular}{|c|} 
Lake \\
Elevation \\
(feet)
\end{tabular} & \begin{tabular}{|c|} 
Tailrace \\
Baro Press. \\
$(\mathrm{mmHg})$ \\
\end{tabular} & \begin{tabular}{|c}
$\begin{array}{c}\text { Relative } \\
\text { Humidity } \\
(\%)\end{array}$ \\
\end{tabular} & \begin{tabular}{|c} 
Turbine Barrel \\
Air Temp \\
$\left({ }^{\circ} \mathrm{C}\right)$
\end{tabular} & $\begin{array}{l}\text { Turbine Barrel } \\
\text { Baro Pressure } \\
(\mathrm{mmHg})\end{array}$ & \begin{tabular}{|c|} 
Original Main \\
Vent Air Flows \\
(cfm)
\end{tabular} & \begin{tabular}{|c|} 
Original Main \\
Vent Standard \\
Air Flows (scfm) \\
\end{tabular} & $\begin{array}{l}\text { New Main Vent } \\
\text { Air Flows }(\mathrm{cfm}) \\
\end{array}$ & \begin{tabular}{|c|} 
New Main Vent \\
Standard Air \\
Flows (scfm) \\
\end{tabular} & $\begin{array}{l}\text { Draft Tube } \\
\text { Temp }\left({ }^{\circ} \mathrm{C}\right) \\
\end{array}$ & \begin{tabular}{|c|} 
Draft Tube Baro \\
Pressure \\
$(\mathrm{mmHg})$
\end{tabular} & $\begin{array}{c}\text { Draft Tube Air } \\
\text { Flow (cfm) }\end{array}$ & \begin{tabular}{|c|} 
Standard Draft \\
Tube Air Flow \\
(scfm)
\end{tabular} & \begin{tabular}{|c|}
$\begin{array}{c}\text { Total Stndrd } \\
\text { Air Flow } \\
\text { (scfm) }\end{array}$ \\
\end{tabular} \\
\hline 1 & $10 \%$ & 1 & Open & Closed & 552.5 & 659.1 & $\begin{array}{l}751 \\
750\end{array}$ & 76 & 29 & 754 & \begin{tabular}{|l|}
21.7 \\
\end{tabular} & 20 & 38 & $\begin{array}{c}40 \\
40\end{array}$ & $\frac{24}{24}$ & $\begin{array}{l}753 \\
753 \\
\end{array}$ & 7,144 & \begin{tabular}{|l|}
6,880 \\
\end{tabular} & \begin{tabular}{|l}
6,940 \\
\end{tabular} \\
\hline 2 & $10 \%$ & 1 & Open & Open & 552.5 & 659.1 & 750 & 63 & 29 & 754 & 14.1 & 10 & 4,198 & 3,980 & 24 & 753 & 3,644 & 3,500 & 7,490 \\
\hline 3 & $10 \%$ & 1 & Closed & Open & 552.4 & 659.2 & 751 & 50 & 29 & 754 & 18.9 & 20 & 7,901 & 7,500 & 24 & 753 & 8 & 10 & 7,530 \\
\hline 4 & $20 \%$ & 3 & Closed & Open & 552.4 & $\begin{array}{ll}659.2 \\
S 50.2\end{array}$ & 750 & 47 & 29 & 754 & $\begin{array}{ll}21.0 \\
2.2\end{array}$ & 20 & 8,629 & 8,190 & 23 & 754 & 7 & 10 & 8,220 \\
\hline 5 & $20 \%$ & 3 & Open & Closed & 552.4 & 659.2 & 750 & 45 & 29 & 754 & 36.3 & 30 & 38 & 40 & 24 & 754 & 8,732 & 8,420 & 8,490 \\
\hline 6 & $30 \%$ & 7 & Open & Closed & 552.4 & 659.2 & 750 & 41 & 29 & 755 & 42.8 & 40 & 38 & 40 & 24 & 754 & 10,038 & 9,660 & 9,740 \\
\hline 7 & $30 \%$ & $\begin{array}{ll}7 \\
14\end{array}$ & Closed & Open & 552.4 & 659.2 & 750 & 39 & 29 & 754 & 20.1 & 20 & 8,690 & 8,230 & 24 & 754 & 7 & 10 & 8,260 \\
\hline 8 & $40 \%$ & 11 & Closed & Open & 552.4 & 659.2 & 750 & 42 & 29 & 754 & 20.7 & 20 & 8,389 & 7,950 & 24 & 754 & 7 & 10 & 7,980 \\
\hline 9 & $40 \%$ & 11 & Open & Closed & 552.4 & 659.2 & 750 & 38 & 29 & 754 & 47.6 & 50 & 39 & 40 & 24 & 754 & 10,694 & 10,290 & 10,380 \\
\hline 10 & $\begin{array}{l}50 \% \\
50 \% \\
\end{array}$ & $\begin{array}{l}15 \\
15\end{array}$ & Open & Closed & $\begin{array}{l}552.4 \\
5525\end{array}$ & 659.2 & 750 & 38 & 29 & 755 & 50.4 & 50 & 39 & 40 & 25 & 754 & 11,809 & 11,340 & 11,430 \\
\hline $\begin{array}{l}12 \\
13 \\
13\end{array}$ & $60 \%$ & $\begin{array}{l}19 \\
19\end{array}$ & Closed & $\begin{array}{c}\text { Open } \\
\text { Close }\end{array}$ & $\begin{array}{l}552.6 \\
5527\end{array}$ & $\frac{659.2}{6592}$ & $\begin{array}{l}750 \\
7750\end{array}$ & $\begin{array}{l}41 \\
38\end{array}$ & 29 & 754 & $\begin{array}{l}19.9 \\
522\end{array}$ & $\begin{array}{l}20 \\
50\end{array}$ & $\frac{6,043}{39}$ & $\frac{0, I<0}{40}$ & $\frac{23}{25}$ & $\begin{array}{l}174 \\
753\end{array}$ & $\begin{array}{c}8 \\
13190\end{array}$ & 12670 & $\begin{array}{c}5,750 \\
12760\end{array}$ \\
\hline$\frac{13}{14}$ & $\frac{60 \%}{70 \% \%}$ & $\frac{19}{22}$ & $\begin{array}{l}\text { Open } \\
\text { Open }\end{array}$ & $\begin{array}{l}\text { Closed } \\
\text { Closed }\end{array}$ & $\frac{552.7}{5528}$ & $\begin{array}{l}659.2 \\
6592\end{array}$ & $\begin{array}{l}750 \\
750\end{array}$ & $\begin{array}{l}38 \\
52\end{array}$ & $\begin{array}{l}30 \\
30\end{array}$ & 754 & $\frac{52.2}{50.1}$ & 50 & 39 & 40 & 25 & 754 & $\frac{19}{12798}$ & $\frac{12}{1220}$ & $\frac{12,760}{12070}$ \\
\hline 15 & $70 \%$ & 22 & Closed & Open & 553.0 & \begin{tabular}{|l|}
659.2 \\
\end{tabular} & 750 & $\begin{array}{l}02 \\
48\end{array}$ & 30 & $\begin{array}{l}754 \\
754\end{array}$ & $\begin{array}{l}0.1 \\
23.4\end{array}$ & 20 & 6.585 & 6,220 & 24 & 754 & 7 & 10 & $\frac{12,370}{6250}$ \\
\hline 16 & $80 \%$ & 25 & Closed & Open & 553.1 & 659.2 & 750 & 50 & 30 & 754 & 24.4 & 20 & 6,816 & $\frac{1,260}{6,440}$ & 24 & 753 & 8 & $\frac{10}{10}$ & $\frac{6,250}{6470}$ \\
\hline 17 & $80 \%$ & 29 & Open & Closed & 553.2 & 659.2 & 750 & 50 & 30 & 754 & 55.3 & 50 & 39 & 40 & 25 & 753 & 11,512 & $\frac{10}{11,060}$ & $\begin{array}{r}6,470 \\
11150\end{array}$ \\
\hline 18 & $90 \%$ & 29 & Open & Closed & 553.3 & 659.2 & 750 & 50 & 30 & 755 & 48.0 & 50 & 39 & 40 & 25 & 753 & 11,139 & $1,10,690$ & $\frac{11,150}{10,780}$ \\
\hline 19 & $90 \%$ & 29 & Closed & Open & 553.4 & 659.2 & 750 & 42 & 30 & 754 & 21.7 & 20 & 5,358 & 5,050 & 24 & 754 & 8 & 10 & $\frac{10,100}{5,080}$ \\
\hline 20 & $90 \%$ & 31 & Closed & Closed & 553.5 & 659.2 & 750 & 47 & 30 & 754 & 58.3 & 60 & 39 & 40 & 24 & 754 & 7 & 10 & 110 \\
\hline 21 & $40 \%$ & 15 & Closed & Closed & 553.5 & 659.2 & 749 & 42 & 31 & 754 & 65.2 & 60 & 46 & 40 & 24 & 753 & 7 & 10 & 110 \\
\hline 1 & $40 \%$ & 11 & Open & Closed & 556.4 & 659.1 & 742 & 48 & 35 & 747 & 58.8 & 50 & 45 & 40 & 25 & 747 & 4,923 & 4,690 & 4,780 \\
\hline 2 & $40 \%$ & 10 & Open & Open & 556.4 & 659.1 & 742 & 46 & 35 & 747 & $\begin{array}{l}17.7 \\
\end{array}$ & 20 & 5,081 & 4,680 & 25 & 747 & 3,871 & 3,680 & 8,380 \\
\hline 3 & $40 \%$ & 11 & Closed & Open & 556.3 & 659.1 & 742 & 46 & 35 & 747 & 19.0 & 20 & 6,263 & 5,770 & 25 & 747 & 8 & 10 & 5,800 \\
\hline 4 & $60 \%$ & 19 & Closed & Open & 556.2 & 659.1 & 742 & 46 & 35 & 747 & 19.7 & 20 & 4,764 & 4,390 & 23 & 747 & 8 & 10 & 4,420 \\
\hline 5 & $60 \%$ & 18 & Open & Open & 556.2 & 659.1 & 742 & 44 & 35 & 747 & 19.0 & 20 & 2,944 & 2,710 & 25 & 747 & 8,160 & 7,770 & 10,500 \\
\hline 8 & $85 \%$ & 29 & Open & Open & 556.3 & $\begin{array}{l}659.1 \\
\end{array}$ & 742 & 45 & 35 & 747 & 20.3 & 20 & 822 & 760 & 26 & 747 & 7,820 & 7,400 & 8,180 \\
\hline 9 & $85 \%$ & 30 & Closed & Open & $\begin{array}{l}556.4 \\
\end{array}$ & $\begin{array}{r}659.1 \\
\end{array}$ & 741 & 44 & 35 & 747 & 20.9 & 20 & 2,657 & 2,440 & 25 & 747 & 13 & 10 & 2,470 \\
\hline 10 & $40 \%$ & 10 & Open & Closed & 560.2 & 659.0 & 741 & 42 & 36 & 746 & 58.5 & 50 & 44 & 40 & 25 & 746 & 1,052 & 1,000 & 1,090 \\
\hline 11 & $40 \%$ & 10 & Open & Open & 560.3 & 659.1 & 741 & 45 & 36 & 746 & $\begin{array}{l}17.0 \\
\end{array}$ & 20 & 3,161 & 2,900 & 25 & 746 & 1,136 & 1,080 & 4,000 \\
\hline 12 & $40 \%$ & 10 & Closed & Open & 560.2 & 659.0 & 741 & 45 & 36 & 747 & 17.8 & 20 & 3,666 & 3,360 & 24 & 746 & 8 & 10 & 3,390 \\
\hline 13 & $60 \%$ & 19 & Closed & Open & 560.2 & 659.0 & 741 & 45 & 36 & 746 & 18.9 & 20 & 3,465 & 3,180 & 23 & 7. & 8 & 10 & 3,210 \\
\hline 14 & $60 \%$ & 18 & Open & Open & 560.2 & 659.0 & 741 & 45 & 36 & 746 & 19.0 & 20 & 2,493 & 2,280 & 25 & & 4,197 & 3,990 & 6,290 \\
\hline 15 & $60 \%$ & 20 & Open & Closed & 560.3 & 659.0 & 741 & 44 & 36 & 74 & $5 \mathrm{c}$ & 50 & 45 & 40 & 25 & 7 & 3,223 & $3, C$ & 3,160 \\
\hline 16 & $85 \%$ & 28 & Open & Closed & 560.2 & 659.0 & 741 & 46 & 36 & 746 & 35 & 30 & 42 & 40 & 27 & 746 & 3 & 3,220 & 3,100 \\
\hline 17 & $85 \%$ & 28 & Open & Open & 560.0 & 659.0 & 741 & 47 & 36 & 74 & 21 & 20 & 272 & 250 & 27 & 746 & 3,274 & 3,090 & 3,360 \\
\hline 18 & $85 \%$ & 29 & Closed & Open & 560.0 & 659.0 & 741 & 49 & 36 & 746 & 20 & & 632 & 580 & 26 & 747 & $\frac{1,277}{12}$ & $\frac{1,000}{10}$ & $\frac{1000}{610}$ \\
\hline 19 & $40 \%$ & 10 & Open & Open & 563.0 & 658.9 & 742 & 50 & 35 & 747 & 16.9 & 20 & 2,428 & 2,230 & 25 & 747 & 2,545 & 2,420 & 4,670 \\
\hline 20 & $40 \%$ & 10 & Open & Closed & 564.0 & 658.9 & 743 & 51 & 35 & 747 & 58.1 & 50 & 45 & 40 & 25 & 747 & 0 & 0 & 90 \\
\hline 21 & $40 \%$ & 10 & Closed & Open & 563.1 & 658.9 & 743 & & 35 & 747 & 16.8 & 20 & 2,382 & 2,190 & 25 & 747 & 26 & 20 & 2,230 \\
\hline 22 & $60 \%$ & 18 & Closed & Open & 563.1 & 659.0 & 743 & 55 & 34 & 748 & 18.9 & 20 & 2,746 & 2,540 & 25 & 748 & 26 & 20 & 2,580 \\
\hline 23 & $60 \%$ & 18 & Open & Open & 563.1 & 659.0 & 744 & 54 & 34 & 748 & 18.8 & 20 & 2,429 & 2,240 & 26 & 749 & 1,820 & 1,730 & 3,990 \\
\hline 24 & $60 \%$ & 19 & Open & Closed & 563.1 & 659.0 & 744 & 55 & 36 & 749 & 64.2 & 60 & 44 & 40 & 25 & 748 & 0 & 0 & 100 \\
\hline 25 & $85 \%$ & 27 & Open & Closed & 563.2 & 659.0 & 744 & 54 & 35 & 749 & 29.4 & 30 & 41 & 40 & 25 & 748 & 1,239 & 1,180 & 1,250 \\
\hline 26 & $85 \%$ & 28 & Open & Open & 563.1 & 659.1 & 744 & 56 & 35 & 749 & 21.5 & 20 & 153 & 140 & 26 & 749 & 1,438 & 1,370 & 1,530 \\
\hline 27 & $85 \%$ & 28 & Closed & Open & 563.1 & 65 & 744 & 56 & 35 & 749 & 21.3 & 20 & 144 & 130 & 26 & 749 & 24 & 20 & 170 \\
\hline 28 & $85 \%$ & 29 & Closed & Closed & 563.3 & 659.0 & 742 & 49 & 35 & 747 & 21.4 & 20 & 140 & 130 & 24 & 747 & 8 & 10 & 160 \\
\hline 29 & $85 \%$ & & Closed & Closed & 563.0 & 659.0 & 744 & 56 & 34 & 749 & 31.1 & 30 & 41 & 40 & 25 & 749 & 7 & 10 & 80 \\
\hline
\end{tabular}


Table 6 continued: 2005 Main Generator 6

\begin{tabular}{|c|c|c|c|c|c|c|c|c|c|c|c|c|c|c|c|c|c|c|c|}
\hline \multicolumn{20}{|c|}{ Measured Values } \\
\hline Run \# & $\begin{array}{l}\text { Gate } \\
\text { Setting } \\
(\%)\end{array}$ & $\begin{array}{l}\text { Unit } \\
\text { Load } \\
\text { (MW) }\end{array}$ & $\begin{array}{l}\text { Draft Tube } \\
\text { Vents }\end{array}$ & $\begin{array}{l}\text { New } \\
\text { Main } \\
\text { Vents }\end{array}$ & $\begin{array}{l}\text { Tailrace } \\
\text { Elev. } \\
\text { (feet) }\end{array}$ & $\begin{array}{l}\text { Lake } \\
\text { Elevation } \\
\text { (feet) }\end{array}$ & $\begin{array}{l}\text { Discharge } \\
\text { (cfs) }\end{array}$ & $\begin{array}{c}\text { Tailrace } \\
\text { Water Temp } \\
\left({ }^{\circ} \mathrm{C}\right)\end{array}$ & \begin{tabular}{|c|} 
Rounded \\
Water Temp \\
$\left({ }^{\circ} \mathrm{C}\right)$
\end{tabular} & $\begin{array}{l}\text { Tailrace } \\
\text { Sp. Cond. } \\
\text { (uS/cm) }\end{array}$ & $\begin{array}{c}\text { TDG } \\
(\mathrm{mmHg})\end{array}$ & $\begin{array}{c}\text { Measured } \\
\text { TDG } \\
\text { (\% Sat) }\end{array}$ & $\begin{array}{c}\text { Calculated } \\
\text { TDG } \\
\text { (\% Sat) }\end{array}$ & $\begin{array}{c}\text { Calculated } \\
\mathrm{P}_{\mathrm{T}} \mathrm{pO} \mathrm{O}_{2} \\
(\mathrm{mmHg})\end{array}$ & $\begin{array}{l}\text { Nitrogen } \\
\text { + Argon } \\
\text { (\% Sat) }\end{array}$ & $\begin{array}{c}\text { Tailrace } \\
\text { DO } \\
\text { (mg/L) }\end{array}$ & $\begin{array}{l}\text { Calculated } \\
\text { Tailrace DO } \\
\text { (\% Sat) }\end{array}$ & $\begin{array}{c}\text { Intake } \\
\text { DO } \\
(\mathrm{mg} / \mathrm{L})\end{array}$ & $\begin{array}{l}\text { Intake } \\
\text { Temp } \\
\left({ }^{\circ} \mathrm{C}\right)\end{array}$ \\
\hline 1 & $10 \%$ & 1 & Open & Closed & 552.5 & 659.1 & 409 & 24.7 & 24.7 & 264 & 876 & $\frac{1}{116}$ & 117 & 749 & 130 & $\frac{6}{6.80}$ & 83.0 & 0.03 & 24.5 \\
\hline 2 & $10 \%$ & 1 & Open & Open & 552.5 & 659.1 & 409 & 24.6 & 24.6 & 265 & 887 & 118 & 118 & 756 & 132 & 7.07 & 86.3 & 0.03 & 24.5 \\
\hline 3 & $10 \%$ & 1 & Closed & Open & 552.4 & 659.2 & 409 & 24.5 & 24.5 & 265 & 896 & 119 & 119 & 761 & 132 & 7.29 & 88.7 & 0.03 & 24.5 \\
\hline 4 & $20 \%$ & 3 & Closed & Open & 552.4 & 659.2 & 818 & 24.6 & 24.6 & 265 & 906 & 120 & 121 & 768 & 134 & 7.41 & 90.4 & 0.03 & 24.6 \\
\hline 5 & $20 \%$ & 3 & Open & Closed & 552.4 & 659.2 & 818 & 24.5 & 24.5 & 265 & 902 & 120 & 120 & 763 & 133 & 7.52 & 91.6 & 0.04 & 24.6 \\
\hline 6 & $30 \%$ & 7 & Open & Closed & 552.4 & 659.2 & 1,260 & 24.7 & 24.7 & 264 & 872 & 116 & 116 & 743 & 129 & 6.94 & 84.9 & 0.12 & 24.6 \\
\hline 7 & $30 \%$ & 7 & Closed & Open & 552.4 & 659.2 & 1,260 & 24.6 & 24.6 & 265 & 872 & 116 & 116 & 750 & 131 & 6.59 & 80.4 & 0.12 & $\frac{24.0}{24.7}$ \\
\hline 8 & $40 \%$ & 11 & Closed & Open & 552.4 & 659.2 & 1,758 & 24.7 & 24.7 & 264 & 875 & 116 & 117 & 758 & 132 & 6.29 & 76.9 & 0.17 & 24.5 \\
\hline 9 & $40 \%$ & 11 & Open & Closed & 552.4 & 659.2 & 1,758 & 24.7 & 24.7 & 264 & 882 & 117 & 118 & 758 & 132 & 6.67 & 81.6 & 0.16 & 24.4 \\
\hline 10 & $50 \%$ & 15 & Open & Closed & 552.4 & 659.2 & 2,239 & 24.9 & 24.9 & 263 & 874 & 116 & 117 & 754 & 131 & 6.44 & 79.0 & 0.19 & 24.5 \\
\hline 11 & $50 \%$ & 15 & Closed & Open & 552.5 & 659.2 & 2,239 & 24.9 & 24.9 & 263 & 835 & 111 & 111 & 735 & 128 & 5.33 & 65.4 & 0.18 & 24.5 \\
\hline 12 & $60 \%$ & 19 & Closed & Open & 552.6 & 659.2 & 2,779 & 24.9 & 24.9 & 262 & 811 & 108 & 108 & 721 & 126 & 4.84 & 59.4 & 0.21 & 24.5 \\
\hline 13 & $60 \%$ & 19 & Open & Closed & 552.7 & 659.2 & 2,779 & 25.0 & 25.0 & 262 & 876 & 116 & 117 & 757 & 132 & 6.38 & 78.5 & 0.20 & 24.5 \\
\hline 14 & $70 \%$ & 22 & Open & Closed & 552.8 & 659.2 & 3,350 & 25.1 & 25.1 & 262 & 863 & 115 & 115 & 748 & 130 & 6.15 & 75.8 & 0.23 & 24.5 \\
\hline 15 & $70 \%$ & 22 & Closed & Open & 553.0 & 659.2 & 3,350 & 25.1 & 25.1 & 262 & 805 & 107 & 107 & 722 & 126 & 4.45 & 54.8 & 0.25 & 24.6 \\
\hline 16 & $80 \%$ & 25 & Closed & Open & 553.1 & 659.2 & 3,947 & 25.2 & 25.2 & 261 & 776 & 103 & 103 & 702 & 122 & 3.97 & 49.0 & 0.28 & 24.6 \\
\hline 17 & $80 \%$ & 29 & $\begin{array}{l}\text { Open } \\
\end{array}$ & Closed & 553.2 & 659.2 & 3,947 & 25.2 & 25.2 & 261 & 827 & 110 & 110 & 726 & 127 & 5.40 & 66.6 & 0.30 & 24.6 \\
\hline 18 & $90 \%$ & 29 & Open & $\begin{array}{ll}\text { Closed } \\
\end{array}$ & 553.3 & 659.2 & 4,344 & 25.3 & 25.3 & 260 & 823 & 109 & 110 & 724 & 126 & 5.27 & 65.2 & 0.29 & 24.6 \\
\hline 19 & $90 \%$ & 29 & Closed & Open & 553.4 & 659.2 & 4,344 & 25.2 & 25.2 & 261 & 760 & 101 & 101 & 692 & 121 & 3.64 & 44.9 & 0.28 & 24.6 \\
\hline 20 & $90 \%$ & 31 & Closed & Closed & 553.5 & 659.2 & 4,344 & 25.2 & 25.2 & 261 & 703 & 93 & 94 & 658 & 115 & 2.42 & 29.9 & 0.28 & 24.6 \\
\hline 21 & $40 \%$ & 15 & Closed & Closed & 553.5 & 659.2 & 1,758 & 24.9 & 24.9 & 263 & 705 & 94 & 94 & 664 & 116 & 2.18 & 26.8 & 0.09 & 24.5 \\
\hline 1 & $40 \%$ & 11 & Open & Closed & 556.4 & 659.1 & 1,800 & 25.3 & 25.3 & 264 & 842 & 113 & 113 & 738 & 130 & 5.54 & 69.3 & 0.61 & 24.7 \\
\hline 2 & $40 \%$ & 10 & Open & Open & 556.4 & 659.1 & 1,800 & 25.3 & 25.3 & 263 & 848 & 114 & 114 & 743 & 131 & 5.59 & 69.9 & 0.67 & 24.7 \\
\hline 3 & $40 \%$ & 11 & Closed & Open & 556.3 & 659.1 & 1,800 & 25.2 & 25.2 & 263 & 842 & 113 & 113 & 742 & 131 & 5.35 & 66 & 0.57 & 24.7 \\
\hline 4 & $60 \%$ & 19 & Closed & Open & 556.2 & 659.1 & 2,796 & 25.2 & 25.2 & 263 & 810 & 109 & 109 & & 128 & 4.43 & 55 & 0.20 & 24.4 \\
\hline 5 & $60 \%$ & 18 & Open & Open & 556.2 & 659.1 & 2,796 & 25.7 & 25.7 & 263 & 857 & 115 & 115 & 749 & 132 & 573 & 72 & 0.62 & 245 \\
\hline 6 & $60 \%$ & 19 & Open & Closed & 556.2 & 659.1 & 2,796 & 25.2 & 25.2 & 263 & 850 & 114 & 115 & 747 & $\frac{102}{132}$ & 5.48 & $6 \varepsilon$ & 0.22 & 24.4 \\
\hline 7 & $85 \%$ & 29 & Open & Closed & 556.2 & 659.1 & 4,136 & 25.5 & 25.5 & 262 & 824 & 111 & 111 & 732 & 129 & 4.87 & 61 & 0.33 & 24.4 \\
\hline 8 & $85 \%$ & 29 & Open & Open & 556.3 & 659.1 & 4,136 & 25.5 & 25.5 & 261 & $\frac{24}{822}$ & 110 & 171 & $\frac{152}{727}$ & 128 & $\frac{4.01}{5.05}$ & 63 & 0.36 & $\begin{array}{l}24.0 \\
2.7\end{array}$ \\
\hline 9 & $85 \%$ & 30 & Closed & Open & 556.4 & 659.1 & 4,136 & 25.5 & 25.5 & 262 & 743 & 100 & 100 & 684 & 121 & 3.12 & 39 & 0.34 & 24.7 \\
\hline 10 & $40 \%$ & 10 & Open & Closed & 560.2 & 659.0 & $\frac{1,792}{1,792}$ & $\frac{20.9}{25.9}$ & 25.9 & 260 & 754 & 100 & 102 & 697 & 123 & 3.03 & $\begin{array}{l}30.4 \\
38.4\end{array}$ & 0.22 & 25.1 \\
\hline 11 & $40 \%$ & 10 & Open & Open & 560.3 & 659.1 & $\begin{array}{l}1,1,792 \\
1,792\end{array}$ & 25.8 & 25.8 & 260 & 839 & 113 & 113 & 745 & 132 & 4.95 & 60.5 & 0.15 & 25.0 \\
\hline 12 & $40 \%$ & 10 & Closed & Open & 560.2 & 659.0 & 1,792 & 25.9 & 25.9 & 260 & 825 & 111 & 111 & 736 & 130 & 4.7 & 59.5 & 0.54 & 25.0 \\
\hline 13 & $60 \%$ & 19 & Closed & Open & 560.2 & 659.0 & 2,780 & 26.0 & 26.0 & 259 & 784 & 105 & 106 & 707 & 125 & 4.05 & 51.4 & 0.54 & 25.1 \\
\hline 14 & $60 \%$ & 18 & Open & Open & 560.2 & 659.0 & 2,780 & 26.0 & 26.0 & 259 & 832 & 112 & 112 & 734 & 130 & 5.17 & 65.6 & 0.54 & 25.0 \\
\hline 15 & $60 \%$ & 20 & Open & Closed & 560.3 & 659.0 & 2,780 & 26.1 & 26.1 & 259 & 742 & 100 & 100 & 678 & 120 & 3.34 & 42.4 & 0.56 & 25.1 \\
\hline 16 & $85 \%$ & 28 & Open & Closed & 560.2 & 659.0 & 4,059 & 26.3 & 26.3 & 258 & 760 & 102 & 103 & 690 & 122 & 3.69 & 47.1 & 0.51 & 25.1 \\
\hline 17 & $85 \%$ & 28 & Open & Open & 560.0 & 659.0 & 4,059 & 26.3 & 26.3 & 258 & 758 & 102 & 102 & 687 & 122 & 3.7 & 47.2 & 0.43 & 25.1 \\
\hline 18 & $85 \%$ & 29 & Closed & Open & 560.0 & 659.0 & 4,059 & 26.4 & 26.4 & 258 & 698 & 94 & 94 & 648 & 115 & 2.6 & 33.2 & 0.43 & 25.1 \\
\hline 19 & $40 \%$ & 10 & Open & Open & 563.0 & 658.9 & 1,765 & 26.6 & 26.6 & 257 & 801 & 107 & 108 & 715 & 126 & 4.5 & 57.6 & 0.40 & 25.3 \\
\hline 20 & $40 \%$ & 10 & Open & Closed & 564.0 & 658.9 & 1,765 & 26.7 & 26.7 & 256 & 708 & 95 & 95 & 653 & 1115 & 2.85 & 36.5 & 0.45 & 25.4 \\
\hline 21 & $40 \%$ & 10 & Closed & Open & 563.1 & 658.9 & 1,765 & 26.6 & 26.6 & 256 & 787 & 105 & 106 & 705 & 124 & 4.29 & 54.9 & 0.45 & 25.5 \\
\hline 22 & $60 \%$ & 18 & Closed & Open & 563.1 & 659.0 & 2,747 & 26.9 & 26.9 & 255 & 778 & 104 & 105 & 695 & 123 & 4.29 & 55.2 & 0.45 & 25.5 \\
\hline 23 & $60 \%$ & 18 & Open & Open & 563.1 & 659.0 & 2,747 & 27.0 & 27.0 & 255 & 797 & 107 & 107 & 704 & 124 & 4.84 & 62.2 & $\begin{array}{l}0.73 \\
\end{array}$ & $\begin{array}{l}25.7 \\
\end{array}$ \\
\hline 24 & $60 \%$ & 19 & Ope & Closed & 563.1 & 659.0 & 2,747 & 27.0 & 27.0 & 255 & 706 & 94 & 95 & 642 & 113 & 3.33 & 42 & 0.86 & 25.7 \\
\hline 25 & $85 \%$ & 27 & Op & Closed & 563.2 & 659.0 & 3,980 & 27.2 & 27.2 & 254 & 115 & 96 & 96 & 642 & 113 & 3.78 & 48 & 0.98 & 25.7 \\
\hline 26 & $85 \%$ & 28 & Open & Open & 563.1 & 659.1 & 3,980 & 27.1 & 27.1 & 254 & 726 & 97 & 98 & 652 & 115 & 3.84 & 49 & 1.04 & 25.8 \\
\hline 27 & $85 \%$ & 28 & Closed & Open & 563.1 & 659.0 & 3,980 & 27.2 & 27.2 & 254 & 692 & 93 & 93 & 629 & 111 & 3.27 & 42.2 & 0.93 & 25.8 \\
\hline 28 & $85 \%$ & 29 & Closed & Closed & 563.3 & 659.0 & 3,980 & 27.3 & 27.3 & 254 & 692 & 93 & 93 & 627 & 111 & 3.34 & 43.3 & 1.14 & 25.8 \\
\hline 29 & $85 \%$ & & Closed & Closed & 563.0 & 659.0 & 3,980 & 27.1 & 27.1 & 254 & 682 & 91 & 92 & 623 & 110 & 3.04 & 39.2 & 0.96 & 25.8 \\
\hline
\end{tabular}


Table 6 continued: 2005 Main Generator 6

\begin{tabular}{|c|c|c|c|c|c|c|c|c|c|c|c|c|c|c|}
\hline \multicolumn{15}{|c|}{ Calculated Values } \\
\hline Run \# & $\begin{array}{l}\text { Gate } \\
\text { Setting } \\
(\%)\end{array}$ & $\begin{array}{l}\text { Unit } \\
\text { Load } \\
\text { (MW) }\end{array}$ & $\begin{array}{l}\text { Draft } \\
\text { Tube } \\
\text { Vents }\end{array}$ & $\begin{array}{l}\text { New } \\
\text { Main } \\
\text { Vents }\end{array}$ & $\begin{array}{l}\text { Tailrace } \\
\text { Elev. } \\
\text { (feet) }\end{array}$ & \begin{tabular}{|c|} 
Lake \\
Elevation \\
(feet)
\end{tabular} & $\begin{array}{l}\text { Aeration } \\
\text { Efficienc }\end{array}$ & \begin{tabular}{|l|} 
Net DO \\
Transfer \\
(mg/L)
\end{tabular} & $\begin{array}{c}\text { O2 in Water } \\
\text { (Ib./min) }\end{array}$ & $\begin{array}{l}\text { O2 in Air } \\
\text { (lb./min) }\end{array}$ & $\begin{array}{l}\text { Air Flow/ } \\
\text { Discharge }\end{array}$ & $\begin{array}{c}\text { Oxygen } \\
\text { Transfer } \\
\text { Efficiency }\end{array}$ & $\begin{array}{c}\text { Oxygen } \\
\text { Transfer } \\
\text { Rate (lb/hr) }\end{array}$ & $\begin{array}{c}\text { OTR/ } \\
\text { Air Discharge }\end{array}$ \\
\hline 1 & $10 \%$ & 1 & Open & Closed & 552.5 & 659.1 & 0.84 & 6.77 & 10.38 & 108.04 & 0.283 & 0.10 & 620 & \\
\hline 2 & $10 \%$ & 1 & Open & Open & 552.5 & 659.1 & 0.87 & 7.04 & 10.79 & 116.01 & 0.305 & 0.09 & 650 & 0.06 \\
\hline 3 & $10 \%$ & 1 & Closed & Open & 552.4 & 659.2 & 0.90 & 7.26 & 11.13 & 116.04 & 0.307 & 0.10 & 670 & 0.06 \\
\hline 4 & $20 \%$ & 3 & Closed & Open & 552.4 & 659.2 & 0.91 & 7.38 & 22.62 & 126.68 & 0.167 & 0.18 & 1,360 & 0.06 \\
\hline 5 & $20 \%$ & 3 & Open & Closed & 552.4 & 659.2 & 0.93 & 7.48 & 22.93 & 132.51 & 0.173 & 0.17 & 1,380 & 0.06 \\
\hline 6 & $30 \%$ & 7 & Open & Closed & 552.4 & 659.2 & 0.86 & 6.82 & 32.18 & 151.63 & 0.129 & 0.21 & 1,930 & 0.04 \\
\hline 7 & $30 \%$ & 7 & Closed & Open & 552.4 & 659.2 & 0.81 & 6.47 & 30.53 & 126.97 & 0.109 & 0.24 & 1,830 & 0.05 \\
\hline 8 & $40 \%$ & 11 & Closed & Open & 552.4 & 659.2 & 0.78 & 6.12 & 40.30 & 122.98 & 0.076 & 0.33 & 2,420 & 0.05 \\
\hline 9 & $40 \%$ & 11 & Open & Closed & 552.4 & 659.2 & 0.82 & 6.51 & 42.87 & 161.60 & 0.098 & 0.27 & 2,570 & 0.04 \\
\hline 10 & $50 \%$ & 15 & Open & Closed & 552.4 & 659.2 & 0.80 & 6.25 & 52.42 & 177.94 & 0.085 & 0.29 & 3,150 & 0.04 \\
\hline 11 & $50 \%$ & 15 & Closed & Open & 552.5 & 659.2 & 0.66 & 5.15 & 43.20 & 96.84 & 0.047 & 0.45 & 2,590 & 0.05 \\
\hline 12 & $60 \%$ & 19 & Closed & Open & 552.6 & 659.2 & 0.59 & 4.63 & 48.19 & 88.39 & 0.034 & 0.55 & 2,890 & 0.05 \\
\hline 13 & $60 \%$ & 19 & Open & Closed & 552.7 & 659.2 & 0.79 & 6.18 & 64.33 & 198.65 & 0.077 & 0.32 & 3,860 & 0.03 \\
\hline 14 & $70 \%$ & 22 & Open & Closed & $\begin{array}{l}552.8 \\
\end{array}$ & 659.2 & 0.76 & 5.92 & 74.27 & 192.09 & 0.062 & 0.39 & 4,460 & 0.03 \\
\hline 15 & $70 \%$ & 22 & Closed & Open & 553.0 & 659.2 & 0.54 & 4.20 & 52.69 & 95.83 & 0.031 & 0.55 & 3,160 & 0.04 \\
\hline 16 & $80 \%$ & 25 & Closed & Open & 553.1 & 659.2 & 0.48 & 3.69 & 54.56 & 99.45 & 0.027 & 0.55 & 3,270 & 0.04 \\
\hline 17 & $80 \%$ & 29 & Open & Closed & 553.2 & 659.2 & $\begin{array}{l}0.66 \\
\end{array}$ & 5.10 & 75.40 & $\begin{array}{l}173.58 \\
\end{array}$ & 0.047 & 0.43 & 4,520 & 0.03 \\
\hline 18 & $90 \%$ & 29 & Open & $\begin{array}{l}\text { Closed } \\
\end{array}$ & 553.3 & 659.2 & 0.65 & 4.98 & 81.03 & $\begin{array}{l}167.82 \\
\end{array}$ & 0.041 & 0.48 & 4,860 & 0.03 \\
\hline 19 & $90 \%$ & 29 & Closed & Open & $\begin{array}{l}553.4 \\
\end{array}$ & 659.2 & 0.44 & 3.36 & 54.67 & 77.89 & 0.019 & 0.70 & 3,280 & 0.04 \\
\hline 20 & $90 \%$ & 31 & Closed & Closed & 553.5 & 659.2 & $\begin{array}{l}0.28 \\
\end{array}$ & 2.14 & 34.82 & $\begin{array}{l}1.69 \\
\end{array}$ & 0.000 & 20.65 & 2,090 & 1.27 \\
\hline 21 & $40 \%$ & 15 & Closed & Closed & 553.5 & 659.2 & 0.26 & 2.09 & 13.76 & 1.72 & 0.001 & 8.02 & 830 & 1.22 \\
\hline 1 & $40 \%$ & 11 & Open & Closed & 556.4 & 659.1 & 0.66 & 4.93 & 33.24 & 74.41 & 0.044 & 0.45 & 1,990 & 0.07 \\
\hline 2 & $40 \%$ & 10 & Open & Open & \begin{tabular}{|l|l}
556.4 \\
556.3
\end{tabular} & $\begin{array}{l}659.1 \\
659.1\end{array}$ & 0.67 & 4.92 & $\begin{array}{l}33.17 \\
2322\end{array}$ & 128.48 & 0.078 & $\begin{array}{l}0.26 \\
0.27\end{array}$ & 1,990 & 0.04 \\
\hline 3 & $40 \%$ & 11 & Closed & Open & $\begin{array}{l}556.3 \\
5562\end{array}$ & $\begin{array}{l}659.1 \\
659.1\end{array}$ & 0.64 & $\begin{array}{l}4.78 \\
\end{array}$ & 32.22 & 87.71 & $\begin{array}{l}0.054 \\
\end{array}$ & 0.37 & 1,930 & 0.05 \\
\hline$\frac{4}{5}$ & $60 \%$ & $\begin{array}{l}19 \\
18\end{array}$ & Closed & Open & $\begin{array}{l}556.2 \\
556.2\end{array}$ & 659.1 & $\begin{array}{l}0.54 \\
0.71\end{array}$ & $\frac{4.23}{551}$ & $\begin{array}{l}44.30 \\
57777\end{array}$ & $\begin{array}{l}66.84 \\
160\end{array}$ & 0.026 & 0.66 & $\begin{array}{r}2,660 \\
3400\end{array}$ & 0.06 \\
\hline$\frac{5}{6}$ & $\frac{60 \%}{60 \%}$ & $\frac{18}{19}$ & $\begin{array}{l}\text { Open } \\
\text { Open }\end{array}$ & $\begin{array}{c}\text { Opend } \\
\text { Clod }\end{array}$ & $\begin{array}{l}556.2 \\
556.2\end{array}$ & $\frac{659.1}{659.1}$ & 0.11 & $\begin{array}{l}5.51 \\
5.26\end{array}$ & $\frac{57.11}{55.09}$ & $\frac{160.99}{14659}$ & 0.0653 & 0.36 & $\begin{array}{r}3,460 \\
33130\end{array}$ & 0.03 \\
\hline 7 & $85 \%$ & 29 & Oppon & Closed & $\begin{array}{l}500.2 \\
5566\end{array}$ & $\frac{059.1}{65991}$ & 0.07 & $\frac{3.20}{4.54}$ & $\begin{array}{l}50.09 \\
70.34\end{array}$ & $\begin{array}{l}\frac{140.09}{118.96} \\
\end{array}$ & $\begin{array}{l}0.000 \\
0.031\end{array}$ & 0.50 & $\frac{0,010}{4,220}$ & 0.04 \\
\hline 8 & $85 \%$ & 29 & Open & Open & 50.2 & 659.1 & 0.61 & 4.69 & 72.66 & 125.42 & 0.033 & 0.58 & $\frac{-7,260}{4,360}$ & 0.04 \\
\hline 9 & $85 \%$ & 30 & Closed & Open & 556.4 & 659.1 & 0.36 & 2.78 & 43.07 & 37.22 & 0.010 & 1.16 & 2,580 & 0.07 \\
\hline 10 & $40 \%$ & 10 & Open & Closed & 560.2 & 659.0 & 0.36 & 2.81 & 18.86 & 16.97 & 0.010 & 1.11 & 1,130 & 0.17 \\
\hline 11 & $40 \%$ & 10 & Open & Open & 560.3 & 659.1 & 0.61 & 4.80 & 32.21 & 61.33 & 0.037 & 0.53 & $\frac{1,1,930}{1,930}$ & 0.08 \\
\hline 12 & $40 \%$ & 10 & Closed & Open & 560.2 & 659.0 & 0.56 & 4.16 & 27.92 & 51.09 & 0.032 & 0.55 & 1,680 & 0.08 \\
\hline 13 & $60 \%$ & 19 & Closed & Open & 560.2 & 659.0 & 0.48 & 3.51 & 36.55 & 48.37 & 0.019 & 0.76 & 2,190 & 0.07 \\
\hline 14 & $60 \%$ & 18 & Open & Open & 560.2 & 659.0 & 0.63 & $\begin{array}{l}4.63 \\
\end{array}$ & 48.22 & 96.44 & 0.038 & 0.50 & 2,890 & 0.05 \\
\hline 15 & $60 \%$ & 20 & Open & Closed & 560.3 & 659.0 & 0.38 & 2.78 & 28.95 & 49.19 & 0.019 & 0.59 & 1,740 & 0.06 \\
\hline 16 & $85 \%$ & 28 & Open & Closed & 560.2 & 659.0 & 0.43 & 3.18 & 48.35 & 50.96 & 0.014 & 0.95 & 2,900 & 0.06 \\
\hline 17 & $85 \%$ & 28 & Open & Open & 560.0 & 659.0 & 0.44 & 3.27 & 49.72 & 51.34 & 0.014 & 0.97 & 2,980 & 0.06 \\
\hline 18 & $85 \%$ & 29 & Closed & Open & 560.0 & 659.0 & 0.29 & 2.17 & 33.00 & 9.19 & 0.003 & 3.59 & 1,980 & 0.24 \\
\hline 19 & $40 \%$ & 10 & Open & Open & 563.0 & 658.9 & 0.55 & 4.10 & 27.11 & 71.60 & 0.044 & 0.38 & 1,630 & 0.06 \\
\hline 20 & $40 \%$ & 10 & Open & Closed & 564.0 & 658.9 & 0.33 & 2.4 & 15 & 1.40 & 0.0 & 11.35 & 950 & 1.72 \\
\hline 21 & $40 \%$ & 10 & Closed & Open & 563.1 & 658.9 & 0.52 & 3.84 & 25.39 & 33.72 & 0.0 & 0.7 & 1,520 & 0.11 \\
\hline 22 & $60 \%$ & 18 & Closed & Open & 563.1 & 659.0 & 0.53 & 3.84 & 39.50 & 39.02 & 0.016 & 1.0 & 2,370 & 0.10 \\
\hline 23 & $60 \%$ & 18 & Open & Open & 563.1 & 659.0 & 0.59 & 4.1 & 42.28 & 61.33 & 0.024 & 0.69 & 2,540 & 0.07 \\
\hline 24 & $60 \%$ & 19 & Open & Closed & 563.1 & 659.0 & 0.36 & 2.47 & 25 & 1.55 & 0.001 & 16.36 & 1,520 & 1.59 \\
\hline 25 & $85 \%$ & 27 & Open & Closed & 563.2 & 659.0 & 0.42 & 2.80 & 41.7 & 19.41 & 0.005 & 2.15 & 2,500 & 0.14 \\
\hline 26 & $85 \%$ & 28 & Open & Open & 563.1 & 659.1 & $\begin{array}{l}0.42 \\
\end{array}$ & 2.80 & 41.74 & 23.46 & 0.006 & 1.78 & 2,500 & 0.12 \\
\hline 27 & $85 \%$ & 28 & Closed & Open & 563.1 & 659.0 & 0.35 & 2.34 & 34.88 & 2.57 & 0.001 & 13.57 & 2,090 & 0.91 \\
\hline 28 & $85 \%$ & 29 & Closed & Closed & 563.3 & 659.0 & 0.34 & 2.20 & $\begin{array}{r}32.79 \\
31.00\end{array}$ & $\begin{array}{r}2.50 \\
125\end{array}$ & 0.001 & $\begin{array}{l}13.13 \\
21.89\end{array}$ & $\frac{1,970}{1}$ & $\frac{0.88}{167}$ \\
\hline 29 & $85 \%$ & & Closed & Closed & 563.0 & 659.0 & 0.31 & $\begin{array}{ll}2.08 \\
\end{array}$ & 31.00 & 1.25 & 0.000 & 24.89 & 1,860 & $\begin{array}{l}1.67 \\
\end{array}$ \\
\hline
\end{tabular}


Table 7: 2005 Main Generator 3 Data

\begin{tabular}{|c|c|c|c|c|c|c|c|c|c|c|c|c|c|c|c|}
\hline \multicolumn{16}{|c|}{ Measured Values } \\
\hline Run \# & $\begin{array}{c}\text { Gate } \\
\text { Setting } \\
(\%)\end{array}$ & $\begin{array}{l}\text { Unit } \\
\text { Load } \\
\text { (MW) }\end{array}$ & $\begin{array}{c}\text { Number of } \\
\text { Main Vents } \\
\text { Open }\end{array}$ & $\begin{array}{c}\text { Tailrace } \\
\text { Elev. } \\
\text { (feet) }\end{array}$ & \begin{tabular}{|c|} 
Lake \\
Elevation \\
(feet)
\end{tabular} & \begin{tabular}{|c|} 
Tailrace \\
Baro Press. \\
(mmHg)
\end{tabular} & $\begin{array}{c}\text { Relative } \\
\text { Humidity } \\
(\%)\end{array}$ & \begin{tabular}{|c|} 
Turbine Barrel \\
Air Temp \\
$\left({ }^{\circ} \mathrm{C}\right)$
\end{tabular} & \begin{tabular}{|c} 
Turbine Barrel Baro \\
Pressure $(\mathrm{mmHg})$
\end{tabular} & $\begin{array}{c}\text { Main Vent Air } \\
\text { Flows (cfm) }\end{array}$ & $\begin{array}{c}\text { Main Vent } \\
\text { Standard Air } \\
\text { Flows (scfm) }\end{array}$ & $\begin{array}{c}\text { Discharge } \\
\text { (cfs) }\end{array}$ & $\begin{array}{c}\text { Tailrace } \\
\text { Water Temp } \\
\left({ }^{\circ} \mathrm{C}\right)\end{array}$ & $\begin{array}{c}\text { Rounded } \\
\text { Water Temp } \\
\left({ }^{\circ} \mathrm{C}\right)\end{array}$ & \begin{tabular}{|c|} 
Tailrace \\
Sp. Cond. \\
(uS/cm)
\end{tabular} \\
\hline 1 & $40 \%$ & 9 & 4 & 556.4 & 659.1 & 742 & 48 & 36 & 748 & 7,422 & 6,820 & 1,784 & 25.1 & 25.1 & 293 \\
\hline 2 & $40 \%$ & 9 & 2 & 556.4 & 659.1 & 742 & 46 & 36 & 748 & 6,677 & 6,140 & 1,784 & 25.0 & 25.0 & 294 \\
\hline 3 & $40 \%$ & 9 & 1 & 556.3 & 659.1 & 742 & 46 & 36 & 747 & 4,801 & 4,410 & 1,784 & 25.0 & 25.0 & 293 \\
\hline 4 & $60 \%$ & 16 & 1 & 556.2 & 659.1 & 742 & 46 & 36 & 747 & 5,143 & 4,720 & 2,760 & 25.1 & 25.1 & 293 \\
\hline 5 & $60 \%$ & 15 & 2 & 556.2 & 659.1 & 742 & 44 & 36 & 747 & 7,504 & 6,880 & 2,760 & 25.1 & 25.1 & 293 \\
\hline 6 & $60 \%$ & 15 & 4 & 556.2 & 659.1 & 742 & 44 & 36 & 747 & 8,320 & 7,630 & 2,760 & 25.1 & 25.1 & 293 \\
\hline 7 & $85 \%$ & 25 & 3 & 556.2 & 659.1 & 742 & 44 & 36 & 747 & 7,120 & 6,530 & 4,185 & 25.4 & 25.4 & 292 \\
\hline 8 & $85 \%$ & 26 & 2 & 556.3 & 659.1 & 742 & 45 & 36 & 747 & 6,870 & 6,300 & 4,185 & 25.4 & 25.4 & 292 \\
\hline 9 & $85 \%$ & 27 & 1 & 556.4 & 659.1 & 741 & 44 & 36 & 747 & 5,070 & 4,640 & 4,185 & 25.4 & 25.4 & 292 \\
\hline 10 & $40 \%$ & 8 & 4 & 560.2 & 659.0 & 741 & 42 & 37 & 747 & 4,413 & 4,040 & 1,767 & 25.3 & 25.3 & 292 \\
\hline 11 & $40 \%$ & 8 & 2 & 560.3 & 659.1 & 741 & 45 & 36 & 746 & 4,364 & 3,990 & 1,767 & 25.4 & 25.4 & 292 \\
\hline 12 & $40 \%$ & 8 & 1 & 560.2 & 659.0 & 741 & 45 & 36 & 746 & 3,765 & 3,450 & 1,767 & 25.3 & 25.3 & 292 \\
\hline 13 & $60 \%$ & 15 & 1 & 560.2 & 659.0 & 741 & 45 & 36 & 746 & 4,190 & 3,840 & 2,745 & 25.5 & 25.5 & 291 \\
\hline 14 & $60 \%$ & 15 & 2 & 560.2 & 659.0 & 741 & 45 & 36 & 746 & 4,957 & 4,540 & 2,745 & 25.6 & 25.6 & 291 \\
\hline 15 & $60 \%$ & 15 & 4 & 560.3 & 659.0 & 741 & 44 & 37 & 746 & 5,654 & 5,170 & 2,745 & 25.5 & 25.5 & 291 \\
\hline 16 & $85 \%$ & 25 & 4 & 560.2 & 659.0 & 741 & 46 & 37 & 746 & 5,523 & 5,050 & 4,184 & 25.8 & 25.8 & 291 \\
\hline 17 & $85 \%$ & 26 & 2 & 560.0 & 659.0 & 741 & 47 & 36 & 746 & 5,645 & 5,170 & 4,184 & 25.8 & 25.8 & 291 \\
\hline 18 & $85 \%$ & 27 & 1 & 560.0 & 659.0 & 741 & 49 & 36 & 746 & 4,546 & 4,160 & 4,184 & 25.8 & 25.8 & 291 \\
\hline 19 & $40 \%$ & 6 & 4 & 563.0 & 658.9 & 742 & 50 & 36 & 747 & 2,684 & 2,470 & 1,755 & 26.5 & 26.5 & 287 \\
\hline 20 & $40 \%$ & 6 & 2 & 564.0 & 658.9 & 743 & 51 & 36 & 747 & 2,694 & 2,480 & 1,755 & 26.0 & 26.0 & 290 \\
\hline 21 & $40 \%$ & 6 & 1 & 563.1 & 659.0 & 743 & & 35 & 747 & 2,272 & 2,090 & 1,755 & 26.0 & 26.0 & 289 \\
\hline 22 & $60 \%$ & 15 & 1 & 563.1 & 659.0 & 743 & 55 & 35 & 748 & 4,232 & 3,910 & 2,745 & 26.4 & 26.4 & 289 \\
\hline 23 & $60 \%$ & 14 & 2 & 563.0 & 659.0 & 744 & 54 & 35 & 749 & 3,981 & 3,670 & 2,745 & 26.3 & 26.3 & 288 \\
\hline 24 & $60 \%$ & 14 & 4 & 563.1 & 659.0 & 744 & 55 & 35 & 749 & 4,084 & 3,770 & 2,745 & 26.4 & 26.4 & 287 \\
\hline 25 & $85 \%$ & 25 & 4 & 563.2 & 659.0 & 744 & 54 & 35 & 749 & 4,634 & 4,280 & 4,179 & 26.4 & 26.4 & 288 \\
\hline 26 & $85 \%$ & 25 & 2 & 563.1 & 659.1 & 744 & 56 & 35 & 749 & 4,709 & 4,350 & 4,179 & 26.6 & 26.6 & 286 \\
\hline 27 & $85 \%$ & 26 & 1 & 563.0 & 659.0 & 744 & 56 & 34 & 749 & 4,110 & 3,800 & 4,179 & 26.5 & 26.5 & 287 \\
\hline 28 & $85 \%$ & 29 & None & 563.3 & 659.0 & 742 & 49 & 36 & 747 & 95 & 90 & 4,179 & 26.4 & 26.4 & 291 \\
\hline 29 & $85 \%$ & & None & 563.0 & 659.0 & 744 & 56 & 34 & 749 & 776 & 720 & 4,179 & 26.3 & 26.3 & 288 \\
\hline
\end{tabular}


Table 7 continued: 2005 Main Generator 3 Data

\begin{tabular}{|c|c|c|c|c|c|c|c|c|c|c|c|c|c|c|}
\hline \multicolumn{15}{|c|}{ Measured Values } \\
\hline Run \# & $\begin{array}{c}\text { Gate } \\
\text { Setting } \\
(\%)\end{array}$ & $\begin{array}{l}\text { Unit } \\
\text { Load } \\
\text { (MW) }\end{array}$ & $\begin{array}{c}\text { Number of } \\
\text { Main Vents } \\
\text { Open }\end{array}$ & $\begin{array}{c}\text { Tailrace } \\
\text { Elev. } \\
\text { (feet) }\end{array}$ & \begin{tabular}{|c} 
Lake \\
Elevation \\
(feet)
\end{tabular} & $\begin{array}{c}\text { TDG } \\
(\mathrm{mmHg})\end{array}$ & \begin{tabular}{|c|} 
Measured \\
TDG \\
(\% Sat)
\end{tabular} & $\begin{array}{c}\text { Calculated } \\
\text { TDG } \\
\text { (\% Sat) }\end{array}$ & \begin{tabular}{|c|} 
Calculated \\
PT-pO2 \\
(mmHg)
\end{tabular} & $\begin{array}{c}\text { Nitrogen } \\
+ \text { Argon } \\
\text { (\% Sat) }\end{array}$ & $\begin{array}{c}\text { Tailrace } \\
\text { DO } \\
\text { (mg/L) }\end{array}$ & $\begin{array}{c}\text { Calculated } \\
\text { Tailrace DO } \\
\text { (\% Sat) }\end{array}$ & $\begin{array}{c}\text { Intake } \\
\text { DO } \\
(\mathrm{mg} / \mathrm{L})\end{array}$ & $\begin{array}{c}\text { Intake } \\
\text { Temp } \\
\left({ }^{\circ} \mathrm{C}\right)\end{array}$ \\
\hline 1 & $40 \%$ & $\overline{9}$ & 4 & 556.4 & 659.1 & 803 & 107 & 108 & 692 & 122 & 5.95 & 74.1 & 0.15 & 25.5 \\
\hline 2 & $40 \%$ & 9 & 2 & 556.4 & 659.1 & 856 & 115 & 115 & 744 & 131 & 5.98 & 74.4 & 0.20 & 25.5 \\
\hline 3 & $40 \%$ & 9 & 1 & 556.3 & 659.1 & 842 & 113 & 113 & 739 & 130 & 5.53 & 68.8 & 0.24 & 25.5 \\
\hline 4 & $60 \%$ & 16 & 1 & 556.2 & 659.1 & 819 & 110 & 110 & 731 & 129 & 4.72 & 58.8 & 0.23 & 25.6 \\
\hline 5 & $60 \%$ & 15 & 2 & 556.2 & 659.1 & 845 & 113 & 114 & 748 & 132 & 5.20 & 64.8 & 0.32 & 25.6 \\
\hline 6 & $60 \%$ & 15 & 4 & 556.2 & 659.1 & 854 & 114 & 115 & 751 & 132 & 5.50 & 68.5 & 0.32 & 25.6 \\
\hline 7 & $85 \%$ & 25 & 3 & 556.2 & 659.1 & 820 & 110 & 111 & 732 & 129 & 4.69 & 58.7 & 0.46 & 25.8 \\
\hline 8 & $85 \%$ & 26 & 2 & 556.3 & 659.1 & 812 & 109 & 109 & 722 & 127 & 4.80 & 60.1 & 0.52 & 25.9 \\
\hline 9 & $85 \%$ & 27 & 1 & 556.4 & 659.1 & 796 & 107 & 107 & 718 & 127 & 4.15 & 52.1 & 0.48 & 25.8 \\
\hline 10 & $40 \%$ & 8 & 4 & 560.2 & 659.0 & 829 & 111 & 112 & 741 & 131 & 4.66 & 58.3 & 0.22 & 25.8 \\
\hline 11 & $40 \%$ & 8 & 2 & 560.3 & 659.1 & 851 & 114 & 115 & 760 & 134 & 4.86 & 61.0 & 0.21 & 25.8 \\
\hline 12 & $40 \%$ & 8 & 1 & 560.2 & 659.0 & 811 & 109 & 109 & 730 & 129 & 4.29 & 53.7 & 0.18 & 25.8 \\
\hline 13 & $60 \%$ & 15 & 1 & 560.2 & 659.0 & 796 & 107 & 107 & 720 & 127 & 4.01 & 50.4 & 0.43 & 26.0 \\
\hline 14 & $60 \%$ & 15 & 2 & 560.2 & 659.0 & 820 & 110 & 111 & 736 & 130 & 4.44 & 55.9 & 0.43 & 26.0 \\
\hline 15 & $60 \%$ & 15 & 4 & 560.3 & 659.0 & 830 & 111 & 112 & 739 & 131 & 4.82 & 60.6 & 0.50 & 26.0 \\
\hline 16 & $85 \%$ & 25 & 4 & 560.2 & 659.0 & 813 & 109 & 110 & 722 & 128 & 4.82 & 60.9 & 0.55 & 26.1 \\
\hline 17 & $85 \%$ & 26 & 2 & 560.0 & 659.0 & 816 & 109 & 110 & 729 & 129 & 4.61 & 58.3 & 0.58 & 26.0 \\
\hline 18 & $85 \%$ & 27 & 1 & 560.0 & 659.0 & 792 & 106 & 107 & 716 & 126 & 4.02 & 50.8 & 0.59 & 26.1 \\
\hline 19 & $40 \%$ & 6 & 4 & 563.0 & 658.9 & 811 & 109 & 109 & 731 & 129 & 4.20 & 53.7 & 0.58 & 26.3 \\
\hline 20 & $40 \%$ & 6 & 2 & 564.0 & 658.9 & 808 & 108 & 109 & 731 & 129 & 4.04 & 51.1 & 0.46 & 26.2 \\
\hline 21 & $40 \%$ & 6 & 1 & 563.1 & 659.0 & 807 & 108 & 109 & 730 & 129 & 4.06 & 51.3 & 0.47 & 26.2 \\
\hline 22 & $60 \%$ & 15 & 1 & 563.1 & 659.0 & 778 & 104 & 105 & 702 & 124 & 3.95 & 50.3 & 0.98 & 26.4 \\
\hline 23 & $60 \%$ & 14 & 2 & 563.0 & 659.0 & 818 & 110 & 110 & 725 & 128 & 4.86 & 61.7 & 1.03 & 26.6 \\
\hline 24 & $60 \%$ & 14 & 4 & 563.1 & 659.0 & 808 & 108 & 109 & 721 & 127 & 4.57 & 58.1 & 1.12 & 26.6 \\
\hline 25 & $85 \%$ & 25 & 4 & 563.2 & 659.0 & 779 & 104 & 105 & 693 & 122 & 4.47 & 56.9 & 1.67 & 27.0 \\
\hline 26 & $85 \%$ & 25 & 2 & 563.1 & 659.1 & 776 & 104 & 104 & 695 & 122 & 4.24 & 54.1 & 1.51 & 27.0 \\
\hline 27 & $85 \%$ & 26 & 1 & 563.0 & 659.0 & 759 & 102 & 102 & 685 & 121 & 3.86 & 49.2 & 1.54 & 26.9 \\
\hline 28 & $85 \%$ & 29 & None & 563.3 & 659.0 & 688 & 92 & 93 & 624 & 110 & 3.36 & 42.9 & 1.94 & 27.2 \\
\hline 29 & $85 \%$ & & None & 563.0 & 659.0 & 683 & 91 & 92 & 635 & 112 & 2.52 & 32.0 & 1.82 & 26.7 \\
\hline
\end{tabular}


Table 7 continued: 2005 Main Generator 3 Data

\begin{tabular}{|c|c|c|c|c|c|c|c|c|c|c|c|c|c|}
\hline \multicolumn{14}{|c|}{ Calculated Values } \\
\hline Run \# & $\begin{array}{c}\text { Gate } \\
\text { Setting } \\
(\%)\end{array}$ & $\begin{array}{l}\text { Unit } \\
\text { Load } \\
\text { (MW) }\end{array}$ & $\begin{array}{c}\text { Number of } \\
\text { Main Vents } \\
\text { Open }\end{array}$ & $\begin{array}{c}\text { Tailrace } \\
\text { Elev. } \\
\text { (feet) }\end{array}$ & \begin{tabular}{|c|} 
Lake \\
Elevation \\
(feet)
\end{tabular} & $\begin{array}{l}\text { Aeration } \\
\text { Efficiency }\end{array}$ & $\begin{array}{l}\text { Net DO } \\
\text { Transfer } \\
\text { (mg/L) }\end{array}$ & $\begin{array}{c}\mathrm{O} 2 \text { in Water } \\
\text { (lb./min) }\end{array}$ & $\begin{array}{l}\text { O2 in Air } \\
\text { (lb./min) }\end{array}$ & $\begin{array}{c}\text { Air Flowl } \\
\text { Discharge }\end{array}$ & $\begin{array}{l}\text { Oxygen } \\
\text { Transfer } \\
\text { Efficiency }\end{array}$ & $\begin{array}{c}\text { Oxygen } \\
\text { Transfer } \\
\text { Rate }(\mathrm{lb} / \mathrm{hr})\end{array}$ & $\begin{array}{c}\text { OTR/ } \\
\text { Air Discharge }\end{array}$ \\
\hline 1 & $40 \%$ & 9 & 4 & 556.4 & 659.1 & 0.73 & 5.80 & 38.75 & 102.78 & 0.064 & 0.38 & 2,320 & 0.06 \\
\hline 2 & $40 \%$ & 9 & 2 & 556.4 & 659.1 & 0.73 & 5.78 & 38.61 & 92.53 & 0.057 & 0.42 & 2,320 & 0.06 \\
\hline 3 & $40 \%$ & 9 & 1 & 556.3 & 659.1 & 0.67 & 5.29 & 35.34 & 66.46 & 0.041 & 0.53 & 2,120 & 0.08 \\
\hline 4 & $60 \%$ & 16 & 1 & 556.2 & 659.1 & 0.57 & 4.49 & 46.41 & 70.88 & 0.029 & 0.65 & 2,780 & 0.06 \\
\hline 5 & $60 \%$ & 15 & 2 & 556.2 & 659.1 & 0.63 & 4.88 & 50.44 & 103.32 & 0.042 & 0.49 & 3,030 & 0.05 \\
\hline 6 & $60 \%$ & 15 & 4 & 556.2 & 659.1 & 0.67 & 5.18 & 53.55 & 114.58 & 0.046 & 0.47 & 3,210 & 0.05 \\
\hline 7 & $85 \%$ & 25 & 3 & 556.2 & 659.1 & 0.56 & 4.23 & 66.31 & 98.06 & 0.026 & 0.68 & 3,980 & 0.04 \\
\hline 8 & $85 \%$ & 26 & 2 & 556.3 & 659.1 & 0.57 & 4.28 & 67.10 & 94.61 & 0.025 & 0.71 & 4,030 & 0.05 \\
\hline 9 & $85 \%$ & 27 & 1 & 556.4 & 659.1 & 0.49 & 3.67 & 57.53 & 69.68 & 0.018 & 0.83 & 3,450 & 0.05 \\
\hline 10 & $40 \%$ & 8 & 4 & 560.2 & 659.0 & 0.57 & 4.44 & 29.38 & 60.67 & 0.038 & 0.48 & 1,760 & 0.07 \\
\hline 11 & $40 \%$ & 8 & 2 & 560.3 & 659.1 & 0.59 & 4.65 & 30.77 & 59.92 & 0.038 & 0.51 & 1,850 & 0.08 \\
\hline 12 & $40 \%$ & 8 & 1 & 560.2 & 659.0 & 0.52 & 4.11 & 27.20 & 51.81 & 0.033 & 0.52 & 1,630 & 0.08 \\
\hline 13 & $60 \%$ & 15 & 1 & 560.2 & 659.0 & 0.47 & 3.58 & 36.81 & 57.67 & 0.023 & 0.64 & 2,210 & 0.06 \\
\hline 14 & $60 \%$ & 15 & 2 & 560.2 & 659.0 & 0.53 & 4.01 & 41.23 & 68.18 & 0.028 & 0.60 & 2,470 & 0.06 \\
\hline 15 & $60 \%$ & 15 & 4 & 560.3 & 659.0 & 0.57 & 4.32 & 44.42 & 77.64 & 0.031 & 0.57 & 2,670 & 0.06 \\
\hline 16 & $85 \%$ & 25 & 4 & 560.2 & 659.0 & 0.58 & 4.27 & 66.92 & 75.84 & 0.020 & 0.88 & 4,020 & 0.06 \\
\hline 17 & $85 \%$ & 26 & 2 & 560.0 & 659.0 & 0.55 & 4.03 & 63.16 & 77.64 & 0.021 & 0.81 & 3,790 & 0.05 \\
\hline 18 & $85 \%$ & 27 & 1 & 560.0 & 659.0 & 0.46 & 3.43 & 53.75 & 62.47 & 0.017 & 0.86 & 3,230 & 0.05 \\
\hline 19 & $40 \%$ & 6 & 4 & 563.0 & 658.9 & 0.50 & 3.62 & 23.79 & 37.22 & 0.023 & 0.64 & 1,430 & 0.10 \\
\hline 20 & $40 \%$ & 6 & 2 & 564.0 & 658.9 & 0.48 & 3.58 & 23.53 & 37.37 & 0.024 & 0.63 & 1,410 & 0.10 \\
\hline 21 & $40 \%$ & 6 & 1 & 563.1 & 659.0 & 0.48 & 3.59 & 23.59 & 31.50 & 0.020 & 0.75 & 1,420 & 0.11 \\
\hline 22 & $60 \%$ & 15 & 1 & 563.1 & 659.0 & 0.43 & 2.97 & 30.54 & 59.13 & 0.024 & 0.52 & 1,830 & 0.05 \\
\hline 23 & $60 \%$ & 14 & 2 & 563.0 & 659.0 & 0.56 & 3.83 & 39.38 & 55.50 & 0.022 & 0.71 & 2,360 & 0.07 \\
\hline 24 & $60 \%$ & 14 & 4 & 563.1 & 659.0 & 0.51 & 3.45 & 35.47 & 57.01 & 0.023 & 0.62 & 2,130 & 0.06 \\
\hline 25 & $85 \%$ & 25 & 4 & 563.2 & 659.0 & 0.45 & 2.80 & 43.83 & 64.72 & 0.017 & 0.68 & 2,630 & 0.04 \\
\hline 26 & $85 \%$ & 25 & 2 & 563.1 & 659.1 & 0.43 & 2.73 & 42.74 & 65.78 & 0.017 & 0.65 & 2,560 & 0.04 \\
\hline 27 & $85 \%$ & 26 & 1 & 563.0 & 659.0 & 0.37 & 2.32 & 36.32 & 57.47 & 0.015 & 0.63 & 2,180 & 0.04 \\
\hline 28 & $85 \%$ & 29 & None & 563.3 & 659.0 & 0.24 & 1.42 & 22.23 & 1.36 & 0.000 & 16.39 & 1,330 & 1.05 \\
\hline 29 & $85 \%$ & & None & 563.0 & 659.0 & 0.12 & 0.70 & 10.96 & 10.89 & 0.003 & 1.01 & 660 & 0.06 \\
\hline
\end{tabular}

